\section{$\mathrm{M}$ ОНИТОРИНГ ПРАВОПРИМЕНЕНИЯ \\ НАУЧНЫЙ РЕЦЕНЗИРУЕМЫЙ ЖУРНАЛ №4(41) - 2021 г. \\ Выходит 4 раза в год}

Зарегистрирован Федеральной службой по надзору в сфере связи, информационных технологий и массовых коммуникаций Свидетельство о регистрации ПИ № ФС77-49472 24 апреля 2012 г.

Журнал входит в перечень научных изданий ВАК

\section{Главный редактор}

КАРЦХИЯ Александр Амиранович, д.Ю.Н., доцент, Москва

Шеф-редактор,

МАКАРЕНКО ГригорИй ИванОВИч, МосКва

\section{Редакционная коллегия}

АНТОНЯн Елена Александровна, д.ю.н., профессор, Москва ГАБОВ Андрей Владимирович, Д.Ю.Н., профессор, член-корреспондент РАН, Москва

ДЕМИДОВА-ПЕТРОВА Елизавета Викторовна, Д.Ю.Н., доцент, Казань

ЗАЙЦЕВ Владимир Васильевич, д.ю.н., профессор, Москва ЗАПОЛЬСКИЙ Сергей Васильевич, д.Ю.н., профессор, Москва ЗАХАРЦЕВ Сергей Иванович, д.Ю.н., профессор, Москва ЗИБОРОВ Олег Валентинович, д.Ю.н.,доцент, Москва КАБАНОВ Павел Александрович, Д.Ю.Н.,Доцент, Казань МАЦКЕВИЧ Игорь МихайлОВич, Д.Ю.Н., профессор, Москва АТАГИМОВА Эльмира Исамудиновна, К.Ю.Н, Москва РАДЧЕНКО Владимир Иванович, К.Ю.Н., доцент, Москва БАБИНЦЕВ Валентин Павлович, д. социол. н., профессор, Белгород МАРКИН Валерий Васильевич, д. социол. н., профессор, Москва МАЛЫШЕВ Михаил ЛЬВович, Д. социол. Н., профессор, Москва Силин Анатолий Николаевич, д. социол. Н., профессор, Тюмень УРЖА Ольга Александровна, д. социол. н., профессор, Москва

\section{Иностранные члены редколлегии}

ШАРШУН Виктор Александрович, к. Ю. н., Минск, Белоруссия

\section{Учредитель и издатель}

ФБУ «Научный центр правовой информации при Министерстве юстиции Российской Федерации»

Адрес: 125438, Москва, Михалковская ул., 65, к.1

E-mail: monitorlaw@yandex.com Телефон: +7-985-939-7501

Требования, предъявляемые к рукописям, а также архивные файлы размещены на сайте: http:/uzulo.su/mon-prav

\section{СОДЕРЖАНИЕ}

\section{ФИЛОСОФИЯ ПРАВА}

К ВОПРОСУ О ПЕРСПЕКТИВАХ СОВРЕМЕННОЙ ИНТЕРПРЕТАЦИИ

ЕСТЕСТВЕННОГО ПРАВА: ФИЛОСОФСКО-ПРАВОВОЙ

И ТЕОЛОГИЧЕСКИЙ АСПЕКТЫ

Захариев С.И., Масленников Д.В., Сальников В.П......... 2

КОНСТИТУЦИОННОЕ ПРАВО

ПРОПОРЦИОНАЛЬНОСТЬ КАК САМОСТОЯТЕЛЬНЫЙ ПРИНЦИП КОНСТИТУЦИОННОГО ПРАВА РОССИЙСКОЙ ФЕДЕРАЦИИ

Хорунжий С.Н. ............................ 9

\section{ЦИВИЛИСТИЧЕСКИЕ НАУКИ}

РЕАЛИЗАЦИЯ «РЕГУЛЯТОРНОЙ ГИЛЬОТИНЫ» НА РЕГИОНАЛЬНОМ И МУНИЦИПАЛЬНОМ УРОВНЯХ

Андреечев И.С. .......................... 21

ИСПОЛНЕНИЕ ОБЯЗАТЕЛЬСТВ ТРЕТЬИМ ЛИЦОМ ПЕРЕД

ЕДИНСТВЕННЫМ КРЕДИТОРОМ ПОСЛЕ ВВЕДЕНИЯ ПРОЦЕДУРЫ НАБЛЮДЕНИЯ

Зайцев В.В., Кравченко А.А., Бедросов В.Э............ 31

ПЕРСПЕКТИВЫ И ПРАВОВЫЕ ПРОБЛЕМЫ РАЗВИТИЯ

МИКРОГЕНЕРАЦИИ В РОССИИ

Коданева С.И.............................. 40

КЛИМАТИЧЕСКОЕ ПРАВО

ЗАКОНОДАТЕЛЬСТВО О КЛИМАТЕ В УСЛОВИЯХ ЭНЕРГОПЕРЕХОДА

К НИЗКОУГЛЕРОДНОЙ ЭКОНОМИКЕ

Карихия А.А................................. 49

ПРАВОВОЕ ПРОСВЕЩЕНИЕ

ОРГАНИЗАЦИЯ ПРАВОВОГО ПРОСВЕЩЕНИЯ В СУБЪЕКТАХ

РОССИЙСКОЙ ФЕДЕРАЦИИ: МОНИТОРИНГ ПРАВОВОГО

РЕГУЛИРОВАНИЯ

Кабанов П.А................................. 56

УГОЛОВНО-ПРАВОВЫЕ НАУКИ

НЕКОТОРЫЕ ПРИЗНАКИ, ХАРАКТЕРИЗУЮЩИЕ КОРРУПЦИОННУЮ ПРЕСТУПНОСТЬ В АГЛОМЕРАЦИЯХ (НА МАТЕРИАЛАХ РЕСПУБЛИКИ TATAPCTAH)

Ахунов Д.Р.............................. 68

ЗНАЧЕНИЕ ДОКАЗАТЕЛЬСТВ В ТЕОРИИ УГОЛОВНО-

ПРОЦЕССУАЛЬНОГО ДОКАЗЫВАНИЯ: ПРОБЛЕМЫ И ПУТИ ИХ РЕШЕНИЯ

Гарипов Т.И............................ 74

ДИСКУССИОННАЯ ТРИБУНА

ПРЕДЛОЖЕНИЯ ПО СОВЕРШЕНСТВОВАНИЮ СИСТЕМЬ

ПРИМЕНЕНИЯ ЦИФРОВЫХ ТЕХНОЛОГИЙ В НОРМОТВОРЧЕСКИХ И

ПРАВОПРИМЕНИТЕЛЬНЫХ ПРОЦЕССАХ

Троян Н.А. . . . . . . . . . . . . . . . . . . . 82

РЕЦЕНЗИИ

РЕЦЕНЗИЯ НА МОНОГРАФИЮ С.И. ЗАХАРЦЕВА «ПРАВО:

НОВЫЕ ИДЕИ И ПРОЧТЕНИЯ»

Сальников В.П., Хабибулин А.Г., Числов А.И........... 93

ОФИЦИАЛЬНЫЕ ПУБЛИКАЦИИ

ДОКЛАД О РЕЗУЛЬТАТАХ МОНИТОРИНГА ПРАВОПРИМЕНЕНИЯ

В РОССИЙСКОЙ ФЕДЕРАЦИИ ЗА 2020 ГОД . . . . . . . . . . . . . .99 


\section{К ВОПРОСУ О ПЕРСПЕКТИВАХ СОВРЕМЕННОЙ ИНТЕРПРЕТАЦИИ ЕСТЕСТВЕННОГО ПРАВА: ФИЛОСОФСКО-ПРАВОВОЙ И ТЕОЛОГИЧЕСКИЙ АСПЕКТЫ}

Захарцев С. И. ${ }^{1}$, Масленников Д. В. ${ }^{2}$, Сальников В. П. ${ }^{3}$

Ключевые слова: философия, философия права, теология, правовые ценности, суверенитет, нормы, государство, право.

\section{Аннотация.}

Цель работы: определение цели и задач современной интерпретации естественного права.

Методы: диалектика и разработанные на ее основе научные методы познания.

Результаты: философско-правовой и историко-правовой анализ становления и развития естественно-правовой парадигмы правового мышления с ее трансформацией в парадигму общественного договора (философия Нового времени) и в парадигму абсолютной свободы личности (немецкая классическая философия) позволяет разработать контуры суверенной философии права России, которая, с одной стороны, могла бы удержать наиболее ценное содержание классических учений европейской и русской философии права, а с другой стороны, с учетом возможностей теологической интерпретации философско-правового знания, была бы способна к дискурсивной экспликации ценностных оснований правовой культуры и правовой жизни народов России.

DOI: 10.21681/2226-0692-2021-4-2-8

$\Gamma$ задача, которая стоит сегодня перед Российским государством, - укрепление и развитие своего суверенитета. Суверенитет, будучи «душой», субъектностью, «идеальностью» государства [6, с. 17-31], не является каким-то раз и навсегда данным качеством. Он должен развиваться вместе с развитием государства, подобно тому, как развивается личность человека, отвечая на всё новые вызовы времени. Как основу личности человека составляет его самосознание, так и основой суверенитета государства является суверенная философия права [22, с. 158]. Невозможно достичь суверенитета государства, выстраивая правовую идеологию на заимствованной философско-правовой платформе. Как мы писали, «национальный суверенитет невозможен, если правовая система государства основана на принципах заимствованной философии права. Невозможно проводить суверенную правовую политику, если она построена на философско-правовой «матрице», сформированной на базе нравственно-правовых ценностей и идеалов научности, выработанных в других государствах... Единственно возможным направлением разработки суверенной философии права, соразмерной российскому традиционализму в области нравственно-правовых ценностей, нам видится актуализация классической философии и метафизики права» $[13$, с. 18].

Исторически сформировалось ограниченное число парадигм философско-правового мышления, в различных вариантах сохраняющих свое влияние до настоящего времени, хотя, как правило, и не действующих в чистом виде, а образующих, скорее, довольно сложные комбинации в пространстве от эклектики до органичного синтеза. Отчасти это многоразличие связано с разнообразием подходов к пониманию предмета философии права $[8$, с. $249-272 ; 9$, с. $64-82 ; 10$, с. $4 ; 32$, с. $8-29 ; 33$, c. $44-62 ; 34$, c. $13-17]$.

Прежде всего здесь следует назвать естественно-правовую парадигму, которая ориентирует на понимание права как всеобеей субстанции, имеющую абсолютную природу с отчетливо выраженным аксиологическим измерением. В эпоху Нового времени формируется парадигма, заданная конвенциональной моделью Гоббса и Локка, в значительной мере определившая характер позитивистского мышления в праве вплоть до современной аналитической юриспруденции. Немецкая классическая философия, возродившая античное понимание мира как всеобщей гармонии, но уже на осно-

\footnotetext{
1 Захарцев Сергей Иванович, доктор юридических наук, заведующий кафедрой адвокатуры и правоохранительной деятельности Российского государственного социального университета, г. Москва, Российская Федерация. E-mail: zakhartsev2306@mail.ru

2 Масленников Дмитрий Владимирович, доктор философских наук, профессор, проректор по научной работе Русской христианской гуманитарной академии, г. Санкт-Петербург, Российская Федерация. E-mail: dwm61@inbox.ru

Сальников Виктор Петрович, доктор юридических наук, профессор, Заслуженный деятель науки Российской Федерации, Почетный работник высшего профессионального образования Российской Федерации, главный редактор журнала «Юридическая наука: история и современность», г. Санкт-Петербург, Российская Федерация. E-mail: fonduniver@bk.ru
} 
ве рационально трактуемых христианских ценностей, формирует принципиально новую парадигму правового мышления, предполагающую дедукцию понятия права из идеи абсолютной свободы [14, с. 248].

Подчеркнем, речь идет именно о парадигмах как образцах, своего рода «порождающих моделях» правового мышления, а не о теоретических системах, которые, как правило, создаются под систематизирующем воздействием нескольких парадигм и включают в себя различные и зачастую малосовместимые концепты. Так, например, теория общественного договора Гоббса не исключала, а предполагала понятия естественного права и естественного закона в качестве продуктов этого договора, хотя и по содержанию, и прежде всего по форме эти понятия, взятые в интерпретации автора «Левиафана», прямо противоположны идее естественного права как объективной субстанции, особенно в ее трактовке Фомой Аквинским [26, с. 24-25]. Также мало общего, кроме самого термина, имела с классическим понятием естественного права соответствующая концепция Савиньи, которую он пытался воспроизвести в рамках парадигмы историзма в праве. И совсем уж неоднозначно дело обстоит с главным течением правовой мысли в XX веке - с неокантианством. Казалось бы, неокантианство должно возрождать идеи основоположника немецкой классической философии, сделавшего первый шаг к утверждению в праве парадигмы «абсолютной свободы». Но в то же время в лице русских неокантианцев делается заявка на «возрождение» естественного права [28, с. 127-138], да и сам автор неокантианского нормативизма Ганс Кельзен не отвергал ни проблематику, ни терминологию естественно-правовой теории [19, с. 6568; 30]. В то же самое время Кельзен продолжал оставаться позитивистом, а в последние годы своего творчества пытался найти подходы к аналитической юриспруденции. При этом и у самих представителей аналитической юриспруденции, начиная с Г. Харта, можно увидеть вполне очевидную актуализацию естественно-правовой мысли, что нам все же представляется достаточно парадоксальным.

С парадигмы естественного права начинается становление теоретического правового мышления в античности [11, с. 164-176]. На протяжении многих веков она была абсолютно доминирующей в теории права Запада и Востока [24, с. 22-28]. Метафизическим основанием естественного права был идеализм Платона. Этот идеализм позволил понять всеобщее мышление как сущность бытия, а идею абсолютного блага в качестве формы единства всеобщего мышления [15, с. 29-37] позволил понять как порождающую модель справедливого государства.

Естественно-правовые учения от Аристотеля до Ульпиана были бы невозможны без этого, обоснованного Платоном, понимания того, что предпосылку бытия единичных вещей, процессов, отношений составляет их причастность всеобщему основанию и это всеобее есть нечто благое, его можно и следует понимать как абсолютное добро. Само различие добра и зла, система ценностей, которыми живет человек, на которых строятся законы морали и нормы права, не являются фантазией, порождением мнения, софистическим оправданием пользы. Они заложены в самих основах устройства мироздания, они объективны, вечны и следовать им составляет благо для человека.

Человек подчиняется нормам морали и права не из страха санкций (по крайней мере, не только и не столько из этого страха), а потому, что он усматривает в этих нормах нечто абсолютно значимое для себя, высшую ценность. К идеализму Платона в этом понимании норм христианство добавило знание их основания как священного (ведь единство сотворенного мира есть не только благо, но и высшая нравственная идея). И еще добавило то, чего не знала античная политическая философия - идею абсолютной свободы. Для христианского мышления высшая нравственная идея - это не только объективная идея мира, но и внутреннее субъективное единство личности. Поэтому следование нормам морали и права - это не только благо для человека, как учили древние философы, но и реализация его собственного личностного содержания.

Таким образом, естественное право должно быть понято не только как объективная субстанция права, но и как его субъективное основание. Однако хотя предпосылка такого понимания была дана уже со вступлением в мир христианской веры и христианского мышления, перевести ее в форму философско-правового дискурса смогли не средневековые христианские схоласты и не адепты теории общественного договора Нового времени, а лишь классики немецкой философии. «Ограниченность состоит в том, что в первом случае дается субстанция права без субъективности, а в другом - субъективность без субстанции. Третий вариант - немецкая классика, которая понимала основу права как активную единую «субстанцию-субъект». Последняя связывалась с восстановленным христианским пониманием свободы, но уже с философски раскрытым его смыслом (наиболее полно и конкретно раскрытым в гегелевском понятии духа)» $[16$, с. 43$]$.

Насколько все же можно говорить о принципиально новой парадигме правовой мысли, созданной представителями немецкой классической философии, или речь идет о своего рода революции в обоснование уже сложившейся до них, традиционной, теории естественного права? Фихте, настаивавший на том, что он впервые выводит основоположения науки из акта свободы как «дела-действия» чистого «Я», называл такую науку, поскольку речь шла о науке о праве, «естественным правом» [27]. На прижизненном издании работы Гегеля также стояло двойное наименование: «Основания естественного права и науки о государстве. Основы философии права». Однако по тексту этого произведения видно, что Гегель старался избегать употребления термина «естественное право», во-первых, в силу его двусмысленной отсылки к «естественному», к внешней природе (особенно в редакции этого термина эпохи Нового времени), а во-вторых, по причине устойчивой ассоциации с метафизическим мышлением Нового времени, его постоянным отсылкам к «врожденным идеям разума», к вечным неизменным сущностям. В более поздних вариантах своей системы Гегель пошел еще дальше, пытаясь нащупать варианты не только философского, но и теологического обоснования абсолютного начала права. Новый и существенный момент в этом обосновании он связывал с экспликацией христологических предпосы- 
лок идеи истории в познании права и государства [10, с. $241-247 ; 17$, с. $159-172 ; 18$, с. 174-182].

Опиравшаяся на немецкую классику русская религиозная философия права, начиная с А.П. Куницына $[20$, с. 51,$54 ; 21$, с. $23-26]$, апеллировала к основному концепту исторической теории естественного права - к идее абсолютного добра. Особенно это характерно для В.С. Соловьева, А.С. Ященко и несколько позднее для И.В. Михайловского. Не развивая подробно, выскажем мысль, что у Соловьева и Ященко абсолютное основание права интерпретируется скорее в платонической традиции (возможно, в ее шеллингианском варианте), чем в духе Гегеля, синтезировавшего методологические принципы трансцендентализма и абсолютного идеализма. Ф.М. Достоевский опосредствовал причастность права идее абсолютного Добра через идею бессмертия души, понимаемую в последовательно православном ключе $[1$, c. $176-180 ; 2$, c. $165-171 ; 3$, c. $74-84 ; 12$, с. 4-6; 25 , c. 179-192].

Творчество Ф.М. Достоевского как автора не только литературных, но и подлинно философско-правовых произведений находится в сфере наших научных интересов $[10 ; 14 ; 34]$. В ценностном круге мышления Ф.М. Достоевского неразрывно связаны между собой Бог, народ, человек. Достоевский показал, что человек, преодолевающий зло и раскрывающей свою сущность в проявлении добра, в добрых поступках, совершает эти поступки в практике богообщения и сохраняет память о них в народе, закрепляя в народной традиции формы осуществления добра. Этим определяется значение человека как высшей ценности. Этому писатель посвятил большинство своих произведений. Как ярко сказал Н.А. Бердяев: «У Достоевского был только один всепоглощающий интерес, только одна тема, которой он отдал все свои творческие силы. Тема эта - человек и его судьба. Не может не поражать исключительный антропологизм и антропоцентризм Достоевского. В поглощенности Достоевского человеком есть исступленность и исключительность. Человек не есть для него явление природного мира, не есть одно из явлений в ряду других, хотя бы и высшее. Человек - микрокосм, центр бытия, солнце, вокруг которого все вращается. Все в человеке и для человека. В человеке - загадка мировой жизни. Решить вопрос о человеке значит решить вопрос и о Боге. Все творчество Достоевского есть предстательство о человеке и его судьбе, доведенное до богоборства, но разрешающееся вручением судьбы человека Богочеловеку-Христу. Такое исключительное антропологическое сознание возможно лишь в христианском мире, лишь в христианскую эпоху истории. Древний мир не знал такого отношения к человеку. Это христианство обратило весь мир к человеку и сделало человека солнцем мира. И антропологизм Достоевского - глубоко христианский антропологизм. И именно исключительное отношение Достоевского к человеку делает его христианским писателем» $[4$, с. 53].

Ф.М. Достоевский придавал исключительное значение неделимости и целостности Российского государства: «Я сам буду стоять за политическую целостность этой громады, до последней капли крови, потому что это единственный хороший результат, приобретенный Россией тысячелетними своими страданиями» [7, с. 178].
Для Ф.М. Достоевского территориальная неделимость России - это не только политическая, но и - прежде всего! - нравственная категория. Мы полагаем, что в рассуждениях писателя о территориальной целостности и единстве России заложены основы для преодоления односторонности позиций славянофилов и западников. Это геополитическое и историческое своеобразие России определило и характер взаимоотношения живущих в ней народов. Государство, созданное совместным историческим творчеством разных народов на пространстве, предназначенном для их совместной жизни, не могло быть основано ни на каком ином принципе, кроме идеи межнациональной гармонии коренных этносов. За все время существования Московского царства, а затем Российской империи ни один из населявших ее народов не прекратил своего существования. Российское государство никогда не знало геноцида народов, который сопровождал историю Европы и Америки. Напротив, народы двигались к своему культурному процветанию: создавалась национальная письменность там, где ее ранее не было, велось преподавание на национальных языках, поддерживались религиозные культы. Со времен Екатерины II не только православное, но и мусульманское духовенство получало материальную поддержку от государства. В отличие от западных ученых-геополитиков, русские евразийцы более последовательно акцентировали связь с почвой не только политических, но и нравственных устремлений народа. Эта составляющая, может быть, не очень явная, позволяет смотреть на Достоевского как на одного из их предшественников, как на «предъевразийца».

Вместе с тем прямо говорить о «возрождении» естественного права в России начал лишь П.И. Новгородцев, связывая его, однако, с неокантианским идеалом практического разума в праве и, по сути, уводя в сторону от традиционного русла естественно-правовой мысли [29, с. 68-77].

С учетом сказанного полагаем, что для создания суверенной философии права современной России недостаточно ни теоретического потенциала классической философии рубежа XVIII - XIX вв., ни русской религиозной философии. Понятно, что использовать опыт зарубежной философии права XX - XXI вв. для решения данной практической задачи можно лишь локально и с учетом серьезного критического анализа.

Что касается теоретического потенциала немецкой классической философии, то даже с учетом ее современного прочтения и переосмысления требуется еще и дискурсивная актуализация национальных нравственно-правовых ценностей. Последняя задача в значительной мере выполнялась в классической русской философии права [23, с. 186-192]. Однако прямое возрождение этой традиции сегодня, во-первых, невозможно в силу целого ряда причин культурологического и образовательного характера, а во-вторых, мы столкнулись бы с несоответствием уровню современного знания и понимания мировой историко-философской и историкоправовой традиции. Речь поэтому может идти только о некотором комплексном, синтетическом подходе.

Насколько будет возможно сохранить для суверенной философии права отсылку к естественно-правовой традиции? С одной стороны, именно эта традиция 
прочно ассоциируется (в том числе и в наше время) с опытом обоснования права посредством отнесения к абсолютным ценностям, вообще к абсолютному. С другой стороны, как и всякое понятие, имеющее длительную историю, понятие естественного права накопило слишком большой объем как позитивных, так и негативных коннотаций.

В любом случае, разрабатывая теоретические основы суверенной философии права, сегодня необходимо с учетом последних достижений отечественной и зарубежной историко-философской и историко-правовой науки еще раз комплексно и системно исследовать естественно-правовую традицию в истории мировой мысли, и уже на этой основе наметить основные линии ее актуализации. Отметим основные узловые моменты этой работы.

Представляется актуальным проанализировать проблему соотношения основного естественно-правового понятия - идеи абсолютного добра - с системой понятий современной политико-правовой теории, определить возможность и целесообразность их теоретического дедуцирования, исходя из этой идеи (в ее возможной современной интерпретации). Необходимо определить точки возможного пересечения теоретических дискурсов, построенных на основе естественно-правовой парадигмы, с теоретическими дискурсами, построенными на основе парадигмы общественного договора и парадигмы абсолютной субстанциальной свободы личности. На этой основе можно разработать контуры оптимальной модели теории современного права, которая, с одной стороны, могла бы удержать наиболее ценное содержание политико-правовых учений прошлого и современности, а с другой стороны, выражала бы ценностные основания правовой жизни народа России.

Данная работа могла бы иметь еще и определенное международно-правовое значение, актуальное для обоснования российского суверенитета. Еще в XVIII в. решая задачу общетеоретического обоснования системы вестфальского мира, выдающийся теоретик права Э. де Ваттель поставил вопрос о существовании особого естественного права для международных отношений, о его онтологическом статусе и о возможной трансформации естественного права при переходе от уровня отдельного лица на уровень «права народов»: «для образования естественного права народов недостаточно просто применять к нациям то, что естественный закон предписывает в отношении лиц» [5, с. 13]. Кризис системы вестфальского мира в XXI в., о котором говорил, в частности, Ю. Хабермас, делает вопрос, поставленный в классической теории естественного права, снова актуальным [31, с. 252-263]. Представляется возможным в ходе теоретического обобщения результатов комплексного историко-правового и философско-правового исследования естественного права дать ответ на него с позиции реалий современной глобализации и регионализации мировых социальных процессов.

Вопрос о значении для человека высших нравственных ценностей и о путях их опосредствования нормами права не может решаться лишь в пределах философско-правового дискурса, поскольку этот вопрос обращается к проблематике, превышающей компетенцию человеческого разума: к проблематике священной природы высших ценностей, к проблематике содержания Священного Писания и Священного Предания, к проблематике отношения человека и Бога. Этот круг проблем относится к сфере теологического знания. Исторически именно традиция естественного права была тем пространством, где происходил диалог теологии и юриспруденции. Этот диалог особенно актуален сегодня, поскольку теология является той сферой знания, которая обладает наибольшим потенциалом противодействия экстремизму и может быть этим значима для современной правовой идеологии.

На теоретической основе современного анализа мировой естественно-правовой традиции можно сформировать систему основных направлений теоретического обеспечения ценностных оснований законотворческой деятельности в Российской Федерации на основе традиций народов России, традиций ее правовой культуры и правосознания, на теоретическом фундаменте классической мировой философско-правовой мысли, а также ее мониторинга. С учетом современной интерпретации классических естественно-правовых идей можно будет разработать современную модель реализации в правоприменительной практике традиционных естественно-правовых принципов справедливости, норм морали (в их отношении к нормам права и принципам законности), а также нравственных идеалов российского народа, и теоретически обосновать механизм соответствующего правового мониторинга.

В целом можно сделать вывод, что идея естественного права в наше время может сохранять свое значение ведущей парадигмы правового мышления, какой она была на протяжении длительной истории государства и общества.

Как нам представляется, в Российской Федерации значение естественно-правовой парадигмы научного мышления будет возрастать в силу прежде всего следующих факторов:

1) усиления роли права в защите нравственных ценностей народов России, в том числе и на конституционном уровне;

2) дальнейшего укрепления национального суверенитета, в том числе на уровне теоретического оформления нравственно-правовых и философско-правовых основ учения о праве и государстве;

3) дальнейшего сближения философии права и теологии как науки, несущий в себе потенциал противодействия экстремизму и основания для межконфессионального диалога по вопросам государственно-правового строительства;

4) непрекращающегося роста интереса к национальному философско-правовому наследию, носители которого были в основном ориентированы на идеалы естественного права. 


\section{Литература}

1. Бастрыкин А.И., Исмагилов Р.Ф., Сальников В.П. Взаимосвязь идеи абсолютного добра и свободы человека в философии права Ф.М. Достоевского // Юридическая наука: история и современность. 2021. № 6. С. 176-181.

2. Бастрыкин А.И., Исмагилов Р.Ф., Сальников В.П. Человек и народ как высшие ценности в философии права Ф.М. Достоевского // Юридическая наука: история и современность. 2021. № 3. С. 165-172.

3. Бастрыкин А.И., Исмагилов Р.Ф., Сальников В.П. Идея права нового времени и философское наследие Ф.М. Достоевского: мировоззренческая оппозиция двух моделей // Правовое государство в современном мире : сборник материалов Международной научно-практической конференции (г. Уфа, 18 мая 2021 г.) / Отв. ред. Н.В. Ямалетдинова. Уфа : РИЦ БашГУ, 2021. С. $74-85$.

4. Бердяев Н.А. Миросозерцание Достоевского. М. : Издатель Захаров, 2001. 172 с.

5. Де Ваттель Э. Право народов, или Принципы естественного права, применяемые к поведению и делам наций и суверенов. М. : Госюриздат, 1960. 179 c.

6. Гегель Г.В.Ф. Философия права. М. : Мысль, 1990. 524 с.

7. Достоевский Ф.М. Полное собрание сочинений в тридцати томах / АН СССР, Институт русской литературы (Пушкинский дом). Т. 20. Статьи и заметки. Л. : Наука. Ленинградское отделение, 1980. 432 с.

8. Захарцев С.И. Право: новые идеи и прочтения. М. : Юрлитинформ, 2021. 440 с. ISBN 978-5-4396-2206-1.

9. Захарцев С.И., Сальников В.П. Философия и юридическая наука. М. : Юрлитинформ, 2019. 424 с. DOI: 10.17513/np.491 .

10. Захарцев С.И., Масленников Д.В., Сальников В.П. Логос права: Парменид - Гегель - Достоевский. К вопросу о спекулятивно-логических основаниях метафизики права. М. : Юрлитинформ, 2019. 376 с. DOI: 10.17513/np.467 .

11. Захарцев С.И., Масленников Д.В., Сальников В.П. Становление логоса права в античной философии // Мир политики и социологии. 2018. № 3-4. С. 164-176.

12. Захарцев С.И., Масленников Д.В., Сальников В.П. Свобода как конкретность идеи абсолютного добра в философии права Достоевского // Мониторинг правоприменения. 2020. № 1 (34). С. 4-7. DOI: 10.21681/2226-0692-2020-1-04-07 .

13. Захарцев С.И., Масленников Д.В., Сальников В.П., Селиверстов И.Н. Суверенитет, государство и организованная преступность: аксиологический аспект // Мониторинг правоприменения. 2021. № 2 (39). С. 13-20. DOI: 10.21681/2226-0692-2021-2-13-20 .

14. Идея свободы. Право. Мораль (классическая и постклассическая философия права) : монография / Под ред. докт. юрид. наук С.И. Захарцева; И.А. Ананских, И.Н. Грибов, С.И. Захарцев, Н.В. Зорина, И.Р. Исмагилов, О.А. Клименко, О.Ю. Лежнева, С.Ф. Мазурин, Б.В Маков, Д.В. Масленников, А.К. Мирзоев, П.А. Петров, Е.А. Поливко, К.Г. Прокофьев, О.В. Пылева, В.П. Сальников, М.В. Сальников, Ф.О. Чудин-Курган. М. : Юрлитинформ, 2020. 288 с.

15. Лебедев С.П. Единое и благо в теологии Платона // Вестник Русской христианской гуманитарной академии. 2020. Т. 21 . № 1. С. $29-37$.

16. Масленников Д.В. Право как форма различения добра и зла // Юридическая мысль. 2015. № 6. С. 42 -47.

17. Масленников Д.В., Любченко В.В. Теологическое и философское содержание учения Гегеля // Вестник Русской христианской гуманитарной академии. 2019. Т. 20. № 4. С. 159-173.

18. Масленников Д.В. Время и вечность в Царстве Отца, Царстве Сына и Царстве Святого Духа (богословский и философский аспект в гегелевской философии религии) // Вестник Русской христианской гуманитарной академии. 2020. Т. 21. № 4-1. С. $174-183$.

19. Ревнов Б.А. Проблема свободы воли в ранней теории чистого учения о праве Г. Кельзена // Юридическая мысль. 2014. № 4 (84). С. $65-69$.

20. Сальников В.П., Романовская Л.Р. Санкт-Петербургская школа естественного права: начало большого пути // Правовое поле современной экономики. 2013. № 11. С. 51-54.

21. Сальников В.П., Романовская Л.Р. Профессор А.П. Куницын у истоков естественной школы права в России // Правовое государство: теория и практика. 2014. № 4. С. 23-26.

22. Сальников В.П., Масленников Д.В., Захарцев С.И., Морозов А.И. Ценностное основание суверенитета (к вопросу о суверенной государственно-правовой идеологии) // Юридическая наука: история и современность. 2019. № 11. С. 149-162.

23. Сальников В.П., Масленников Д.В., Захарцев С.И., Сальников М.В. Развитие идеи абсолютной свободы в классической русской философии как источник суверенной философии права // Юридическая наука: история и современность. 2019. № 12. C. $185-193$.

24. Сальников В.П., Романовская В.Б., Сальников М.В., Горбунов М.Д. Абсолютное и относительное в естественном праве // Мир политики и социологии. 2015. № 11. С. 22-29.

25. Сальников В.П., Исмагилов Р.Ф., Масленников Д.В., Захарцев С.И., Сальников М.В. Бессмертие души как стержневая идея в учении Ф.М. Достоевского о праве и нравственности // Юридическая наука: история и современность. 2021. № 5. С. $179-192$.

26. Сальников В.П., Исмагилов Р.Ф., Сальников М.В. Платон, Аристотель, Фома Аквинский и идея справедливости в естественно-правовой традиции // Мир политики и социологии. 2016. № 9. С. 19-26.

27. Фихте И.Г. Основа естественного права согласно принципам наукоучения. М. : Канон+, 2014. 392 с.

28. Фролова Е.А. Рациональные основания права: классика и современность. М. : Проспект, 2020. 576 с.

29. Фролова Е.А. Методологические основы неокантианского учения П.И. Новгородцева // Государство и право. 2012. № 5. C. 68-78.

30. Kelsen H. Die philosophischen Grundlagen der Naturrechtslehre und des Rechtspositivismus, Berlin: Pan-Verlag Rolf Heise, 1928.

31. Przylebski A. Hegel und die Idee des internationalen Rechts // Recht ohne Gerechtigkeit? Hegel und die Grundlinien des Rechtsstaates. Herausgegeben von M. Wischke, A. Przylebski. Würzburg: Königshausen - Neumann, 2010. S. 252-263.

32. Захарцев С.I. Філософія і теорія права : монографія / Передмова О.М. Клюева. Харків: Панов, 2015. 256 c. DOI: 10.17513/np.471 . 
33. Zakhartsev S.I., Salnikov V.P. The Philosophy of Law and Legal Science. Newcastle upon Tyne: Cambridge Scholars Publishing, 2018. 270 p. DOI: $10.17513 / \mathrm{np} .452$.

34. Zakhartsev S.I., Maslennikov D.V., Salnikov V.P. The Logos of Law: Parmenides - Hegel — Dostoevsky: The Speculative and Logical Foundations of The Metaphysics of Law. London, 2021. DOI: 10.17513/np.490 .

\title{
ON THE QUESTION OF PROSPECTS FOR A MODERN INTERPRETATION OF NATURAL LAW: LEGAL PHILOSOPHICAL AND THEOLOGICAL ASPECTS
}

\author{
S. Zakhartsev ${ }^{4}$, D. Maslennikov ${ }^{5}$, V. Sal'nikov ${ }^{6}$ \\ Keywords: philosophy, philosophy of law, theology, legal values, sovereignty, standards, state, law.

\section{Abstract.} \\ Purpose of the work: determining the goal and tasks of modern interpretation of natural law. \\ Methods used: dialectics and scientific methods of cognition developed based on it. \\ Results obtained: a legal philosophical and historical philosophical analysis of formation and development of the \\ natural law paradigm of legal thought with its transformation into the social contract paradigm (philosophy of the New \\ Time) and the absolute individual freedom paradigm (classical German philosophy) makes it possible to work out an \\ outline of the sovereign philosophy of Russian law which, on the one hand, could preserve the most valuable content of \\ the classical doctrines of the European and Russian philosophy of law and, on the other hand, considering the possibilities \\ of a theological interpretation of legal philosophical knowledge, would be capable of a discursive explication of value \\ foundations of the legal culture and legal life of peoples of Russia.
}

\section{References}

1. Bastrykin A.I., Ismagilov R.F., Sal'nikov V.P. Vzaimosviaz' idei absoliutnogo dobra i svobody cheloveka v filosofii prava F.M. Dostoevskogo. Iuridicheskaia nauka: istoriia i sovremennost', 2021, No. 6, pp. 176-181.

2. Bastrykin A.I., Ismagilov R.F., Sal'nikov V.P. Chelovek i narod kak vysshie tsennosti v filosofii prava F.M. Dostoevskogo. Iuridicheskaia nauka: istoriia i sovremennost', 2021, No. 3, pp. 165-172.

3. Bastrykin A.I., Ismagilov R.F., Sal'nikov V.P. Ideia prava novogo vremeni i filosofskoe nasledie F.M. Dostoevskogo: mirovozzrencheskaia oppozitsiia dvukh modelei. Pravovoe gosudarstvo v sovremennom mire : sbornik materialov Mezhdunarodnoi nauchno-prakticheskoi konferentsii (g. Ufa, 18 maia 2021 g.). Otv. red. N.V. Iamaletdinova. Ufa : RITs BashGU, 2021, pp. 74-85.

4. Berdiaev N.A. Mirosozertsanie Dostoevskogo. M. : Izdatel' Zakharov, 2001. 172 pp.

5. De Vattel' E. Pravo narodov, ili Printsipy estestvennogo prava, primeniaemye k povedeniiu i delam natsii i suverenov. M. : Gosiurizdat, 1960. 179 pp.

6. Gegel' G.V.F. Filosofiia prava. M. : Mysl', 1990. 524 pp.

7. Dostoevskii F.M. Polnoe sobranie sochinenii v tridtsati tomakh. AN SSSR, Institut russkoi literatury (Pushkinskii dom). T. 20. Stat'i i zametki. L. : Nauka. Leningradskoe otdelenie, 1980. 432 pp.

8. Zakhartsev S.I. Pravo: novye idei i prochteniia. M. : Iurlitinform, 2021. 440 pp. ISBN 978-5-4396-2206-1.

9. Zakhartsev S.I., Sal'nikov V.P. Filosofiia i iuridicheskaia nauka. M. : Iurlitinform, 2019. 424 pp. DOI: 10.17513/np.491 .

10. Zakhartsev S.I., Maslennikov D.V., Sal'nikov V.P. Logos prava: Parmenid -- Gegel' -- Dostoevskii. K voprosu o spekuliativnologicheskikh osnovaniiakh metafiziki prava. M. : Iurlitinform, 2019. 376 c. DOI: 10.17513/np.467 .

11. Zakhartsev S.I., Maslennikov D.V., Sal'nikov V.P. Stanovlenie logosa prava v antichnoi filosofii. Mir politiki i sotsiologii, 2018, No. 3-4, pp. 164-176.

12. Zakhartsev S.I., Maslennikov D.V., Sal'nikov V.P. Svoboda kak konkretnost' idei absoliutnogo dobra v filosofii prava Dostoevskogo. Monitoring pravoprimeneniia, 2020, No. 1 (34), pp. 4-7. DOI: 10.21681/2226-0692-2020-1-04-07 .

13. Zakhartsev S.I., Maslennikov D.V., Sal'nikov V.P., Seliverstov I.N. Suverenitet, gosudarstvo i organizovannaia prestupnost': aksiologicheskii aspekt. Monitoring pravoprimeneniia, 2021, No. 2 (39), pp. 13-20. DOI: 10.21681/2226-0692-2021-2-13-20 .

\footnotetext{
4 Sergei Zakhartsev, Dr.Sc. (Law), Head of the Department of Public Defence and Organisation of Law Enforcement Activities of the Russian State Social University, Moscow, Russian Federation. E-mail: zakhartsev2306@mail.ru

5 Dmitrii Maslennikov, Dr.Sc. (Philosophy), Professor, Vice-Rector for Research of the Russian Christian Humanitarian Academy, Saint Petersburg, Russian Federation. E-mail: dwm61@inbox.ru

6 Viktor Sal'nikov, Dr.Sc. (Law), Professor, Meritorious Scientist of the Russian Federation, Honorary Worker of Higher Professional Education of the Russian Federation, Editor-in-Chief of the Journal “Legal Science: History and the Present”, Saint Petersburg, Russian Federation. E-mail: fonduniver@bk.ru
} 
14. Ideia svobody. Pravo. Moral' (klassicheskaia i postklassicheskaia filosofiia prava) : monografiia. Pod red. dokt. iurid. nauk S.I. Zakhartseva; I.A. Ananskikh, I.N. Gribov, S.I. Zakhartsev, N.V. Zorina, I.R. Ismagilov, O.A. Klimenko, O.Iu. Lezhneva, S.F. Mazurin, B.V Makov, D.V. Maslennikov, A.K. Mirzoev, P.A. Petrov, E.A. Polivko, K.G. Prokof'ev, O.V. Pyleva, V.P. Sal'nikov, M.V. Sal'nikov, F.O. Chudin-Kurgan. M. : Iurlitinform, 2020. 288 pp.

15. Lebedev S.P. Edinoe i blago v teologii Platona. Vestnik Russkoi khristianskoi gumanitarnoi akademii, 2020, t. 21, No. 1, pp. $29-37$.

16. Maslennikov D.V. Pravo kak forma razlicheniia dobra i zla. Iuridicheskaia mysl', 2015, No. 6, pp. $42-47$.

17. Maslennikov D.V., Liubchenko V.V. Teologicheskoe i filosofskoe soderzhanie ucheniia Gegelia. Vestnik Russkoi khristianskoi gumanitarnoi akademii, 2019, t. 20, No. 4, pp. 159-173.

18. Maslennikov D.V. Vremia i vechnost' v Tsarstve Ottsa, Tsarstve Syna i Tsarstve Sviatogo Dukha (bogoslovskii i filosofskii aspekt v gegelevskoi filosofii religii). Vestnik Russkoi khristianskoi gumanitarnoi akademii, 2020, t. 21, No. 4-1, pp. 174-183.

19. Revnov B.A. Problema svobody voli v rannei teorii chistogo ucheniia o prave G. Kel'zena. Iuridicheskaia mysl', 2014, No. 4 (84), pp. 65-69.

20. Sal'nikov V.P., Romanovskaia L.R. Sankt-Peterburgskaia shkola estestvennogo prava: nachalo bol'shogo puti. Pravovoe pole sovremennoi ekonomiki, 2013, No. 11, pp. 51-54.

21. Sal'nikov V.P., Romanovskaia L.R. Professor A.P. Kunitsyn u istokov estestvennoi shkoly prava v Rossii. Pravovoe gosudarstvo: teoriia i praktika, 2014, No. 4, pp. 23-26.

22. Sal'nikov V.P., Maslennikov D.V., Zakhartsev S.I., Morozov A.I. Tsennostnoe osnovanie suvereniteta (k voprosu o suverennoi gosudarstvenno-pravovoi ideologii). Iuridicheskaia nauka: istoriia i sovremennost', 2019, No. 11, pp. 149-162.

23. Sal'nikov V.P., Maslennikov D.V., Zakhartsev S.I., Sal'nikov M.V. Razvitie idei absoliutnoi svobody v klassicheskoi russkoi filosofii kak istochnik suverennoi filosofii prava. Iuridicheskaia nauka: istoriia i sovremennost', 2019, No. 12, pp. 185-193.

24. Sal'nikov V.P., Romanovskaia V.B., Sal'nikov M.V., Gorbunov M.D. Absoliutnoe i otnositel'noe v estestvennom prave. Mir politiki i sotsiologii, 2015, No. 11, pp. 22-29.

25. Sal'nikov V.P., Ismagilov R.F., Maslennikov D.V., Zakhartsev S.I., Sal’nikov M.V. Bessmertie dushi kak sterzhnevaia ideia v uchenii F.M. Dostoevskogo o prave i nravstvennosti. Iuridicheskaia nauka: istoriia i sovremennost', 2021, No. 5, pp. 179-192.

26. Sal'nikov V.P., Ismagilov R.F., Sal'nikov M.V. Platon, Aristotel', Foma Akvinskii i ideia spravedlivosti v estestvenno-pravovoi traditsii. Mir politiki i sotsiologii, 2016, No. 9, pp. 19-26.

27. Fikhte I.G. Osnova estestvennogo prava soglasno printsipam naukoucheniia. M. : Kanon+, 2014. 392 pp.

28. Frolova E.A. Ratsional'nye osnovaniia prava: klassika i sovremennost'. M. : Prospekt, 2020. 576 pp.

29. Frolova E.A. Metodologicheskie osnovy neokantianskogo ucheniia P.I. Novgorodtseva. Gosudarstvo i pravo, 2012, No. 5, pp. 68-78.

30. Kelsen H. Die philosophischen Grundlagen der Naturrechtslehre und des Rechtspositivismus, Berlin: Pan-Verlag Rolf Heise, 1928.

31. Przylebski A. Hegel und die Idee des internationalen Rechts. Recht ohne Gerechtigkeit? Hegel und die Grundlinien des Rechtsstaates. Herausgegeben von M. Wischke, A. Przylebski. Würzburg: Königshausen - Neumann, 2010. S. 252-263.

32. Zakhartsev S.I. Filosofiia i teoriia prava : monohrafiia. Peredmova O.M. Kliueva. Kharkiv: Panov, 2015. 256 pp. DOI: $10.17513 / n p .471$.

33. Zakhartsev S.I., Salnikov V.P. The Philosophy of Law and Legal Science. Newcastle upon Tyne: Cambridge Scholars Publishing, 2018. 270 p. DOI: $10.17513 /$ np.452 .

34. Zakhartsev S.I., Maslennikov D.V., Salnikov V.P. The Logos of Law: Parmenides -- Hegel -- Dostoevsky: The Speculative and Logical Foundations of The Metaphysics of Law. London, 2021. DOI: 10.17513/np.490 . 


\section{ПРОПОРЦИОНАЛЬНОСТЬ КАК САМОСТОЯТЕЛЬНЫЙ КОНСТИТУЦИОННЫЙ ПРИНЦИП РОССИЙСКОЙ ФЕДЕРАЦИИ}

\section{Хорунжий С. Н. ${ }^{1}$}

Ключевые слова: конституционный принцип, соразмерность, необходимость, пригодность, баланс конституционно защищаемых ценностей, деконструкция.

\section{Аннотация.}

Цель работы: анализ и выявление признаков пропорциональности как самостоятельного принципа конституционного права; составление матрицы элементов пропорциональности, обеспечивающих условия реализации конституционной пропорциональности.

Методы исследования: научно-доктринальный, юридико-догматический, сравнительно-правовой, герменевтический.

Результаты исследования: установлено, что принцип пропорциональности является самостоятельным, выступает одной из фундаментальных правовых основ, регламентирующих конституционные правоотношения, обладающих высокой степенью юридической абстракции, содержанием которой является процедурно-процессуальная модель применения условий и критериев достижения справедливости, реализация которой носит пруденциальный по отношению к обеспечению баланса конституционно защищаемых ценностей характер.

Исполнение процедурно-процессуальной модели становится не только фактом правоприменения принципа пропорциональности, но является условием его реализации. В этом состоит основополагающее отличие содержания принципа пропорциональности от других конституционных принципов права. С учетом конституционной пропорциональности как самостоятельного феномена правовой действительности, принцип пропорциональности обретает свое содержание исключительно в процессе его реализации. Последнее предполагает последовательное соблюдение условий и критериев, представленных в упомянутой матрице пропорциональности.

Категории, признаки и условия обеспечения баланса конституционно защищаемых ценностей были сведены в комплексную матрицу, демонстрирующую собственно действие принципа конституционной пропорциональности.

Представленная в работе авторская модель матрицы пропорциональности позволяет обеспечить баланс между материальными и процессуально-процедурными принципами, компетенцией госоргана и судебным контролем (надзором), эпистемологической неопределенностью и прямыми нормами Основного закона.

Принцип пропорциональности выявляет адекватность способов и границ реализации прав и законных интересов, влияет на определение непосредственных форм и процедур, инструментов и механизмов законотворчества и правоприменения.

DOI: 10.21681/2226-0692-2021-4-9-20

\section{Введение}

$\Pi_{\mathrm{p}}$ нию к нормам материального права состоит в том, что к ним не предъявляются требования четкой юридической формализации, без чего не может эффективно существовать норма материального права ${ }^{2}$. По этой же причине именно принципы имеют столь существенное значение при определении границ про-

\footnotetext{
2 Алексеев С.С. Общая теория права. В 2-х т., т. І. М. : Юридическая литература, 1981. С. 51.
}

порциональности в ходе реализации дискреционных полномочий субъектами конституционных правоотношений.

Для отечественной правовой мысли традиционным является рассмотрение правовых принципов как неких фундаментальных правовых начал, пронизывающих ту или иную отрасль права, основные направления правового регулирования. Как указывал в свое время С.С. Алексеев, принцип права характеризуют исход-

\footnotetext{
1 Хорунжий Сергей Николаевич, секретарь избирательной комиссии Воронежской области, кандидат юридических наук, доцент кафедры конституционного и муниципального права юридического факультета Воронежского государственного университета, г. Воронеж, Российская Федерация. E-mail: snhor@me.com
} 
ные нормативно-руководящие начала соответствующей правовой системы, которые играют более существенную роль, нежели правовые явления, выражающие содержание права, выступая в качестве самостоятельных «высокозначимых регулятивных элементов в структуре права» . Здесь же ученый выделил основные признаки, свойственные принципам права: норма права существует наряду с принципом права, не перекрывая его; принцип права имеет собственное место (звено) в структуре права в качестве регулятивного элемента; в силу указанных особенностей юридической природы принципы права предопределяют вектор правоприменительной практики, включая судебную. Последнее позволяет рассматривать принцип в качестве «механизма саморегулирования в системе права» ${ }^{4}$.

Основанием для представленного понимания принципа является высказанное в свое время проф. С.С. Алексеевым и весьма близкое для излагаемой в настоящей работе концепции понимание права в виде идеологического явления, где руководящие и концентрированные начала раскрываются как принципы, выявляющие сущность права, его основы и тенденции развития. Профессор справедливо указал на глубокую обусловленность и связанность принципов права с особенностями правовой системы того или иного исторического типа, общественно-экономической формации.

Правовой принцип в качестве «основополагающих начал правового регулирования» или «руководящих идей» [2], не давая четкой формально-юридической фиксации возможного или должного, определяет допустимые варианты и формы поведения $[16,16]$. В научной литературе отмечалось также, что применение принципов права более характерно для процессуальных отраслей права, нежели для материальных [4, с. 98-107].

\section{Постановка задачи}

\section{I. Правовая характеристика конституционных принципов}

В конституционном праве выделяют «общие конституционные принципы, или принципы конституции», а также «частные, или институциональные, конституционные принципы», «писаные» или «неписаные», каждые из которых, в свою очередь, могут включать в себя самостоятельные группы и виды конституционных принципов [3]. В.Е. Чиркин о конституционных принципах говорит как о нормах высокой степени обобщенности ${ }^{5}$.

Следует также помнить и другие степени юридической абстракции в понимании конституционных принципов, высказанные в свое время в науке. Так, О.Е. Кутафин в качестве таковых определял «устои государства», под которыми он определял прежде всего «основы конституционного строя» ${ }^{6}$. Схожего мнения

\footnotetext{
Алексеев С.С. Общая теория права. В 2-х т., т. I. М. : Юридическая литература, 1981. С. 51.

4 Черданцев А.Ф. Системность норм права / Сборник научных трудов СЮИ. Вып. 12, Свердловск, 1970. С. 49.

5 Чиркин В.Е. Конституционное право России. М. : Норма, 2009. С. 25. 6 Козлова Е.И., Кутафин О.Е. Конституционное право России : учебник. 3-е изд. М. : Юрист, 2002. С. 125.
}

придерживался М.В. Баглай, утверждавший, что нормыпринципы интегрированы в первую главу Конституции РФ как основы конституционного строя ${ }^{7}$.

Заметим, что слабость юридической формализации конституционного принципа, неопределенность его правового содержания, сближающая его более с нормами морали, нравственности, а также идеологическими постулатами, дает основание некоторым ученым не учитывать принципы в качестве самостоятельного элемента системы права, которые приобретают юридическое звучание лишь в рамках действия конкретных норм права.

В этом смысле можно говорить о схожести неюридических ценностей с аксиологическими характеристиками конституционных ценностей по таким критериям, как:

a) нормативное содержание ценностей (принципы, идеалы, стандарты);

б) наличие социально-полезной цели (оптимальное развитие общества и государства); жения).

в) правовая форма (конституционные правополо-

В зарубежных исследованиях разброс мнений также весьма велик даже на уровне квалификации принципа как самостоятельной ценности. Так, Р. Алекси указывает, что, несмотря на единую концептуальную структуру, принципы и ценности имеют различные сферы действия: принципы находятся в сфере должного (деонтологического), а ценности - в сфере предпочитаемого (аксиологического) [17, с. 93]. Представляется, что такое деление в рассматриваемом нами конституционном аспекте достаточно существенно, поскольку категория «должного» требует обязательного исполнения, в то время как категория «предпочитаемого» находится в сфере адиафорного порядка, ценностное содержание которого может быть абсолютно безразлично, что исключает какие-либо требования к соблюдению подобных ценностей.

Следует также сказать о неоднократно отмеченной в российской и зарубежной научной литературе тонкой правовой грани, отделяющей конституционные ценности от конституционных принципов $[5,6,11,15$, $8,19,20]$.

Особенность рассматриваемых здесь вопросов требует также упомянуть возможность защиты конституционных ценностей. Последняя реализуется, в частности, благодаря механизмам конституционного нормоконтроля, обеспечивающих нормативно-преобразующее перепостроение действующих норм права, идея которого изложена в предшествующих частях работы.

Все же в большей части исследований, посвященных анализу юридической природы принципов, последние рассматриваются в качестве самостоятельного элемента системы права, отдельно стоящего по отношению к традиционным правовым нормам. Полагаем, для этого есть все основания.

Так, для норм-правил характерно требование определенного поведения: рекомендуемого, допускаемого или запрещенного для исполнения. Соответственно, такие требования норм права можно либо выполнить, либо нет. В сфере правореализационного действия прин-

Баглай М.В. Конституционное право Российской Федерации : учебник для вузов. 2-е изд. М. : Норма, 2000. С. 99. 
ципов права характер исполняемого требования состоит несколько в ином, а именно - в максимальном соответствии заложенной в юридической абстракции идеи, причем темпорально непрерывно. Например, принцип справедливости предполагает соответствующую направленность действий со стороны всех участников на протяжении всего периода правового взаимодействия. Иными словами, можно говорить о степени выполнения (в смысле - достижения) принципа.

Кроме того, в науке конституционного права закрепленные в Основном законе принципы предлагается рассматривать в их бинарном сочетании - когда разнонаправленные принципы раскрываются в непротиворечивой взаимосвязи, в основе которой лежит идея социального интереса. Так, Г.А. Гаджиев говорит о бинарности таких принципов, как свобода выборов и свобода выражения мнений, государственный суверенитет и личностная автономия, государственность и народовластие, свобода предпринимательской деятельности и социального государства и др. [5]. Взаимообусловленность бинарных принципов, их общая целевая сопряженность позволяет обеспечить баланс различных конституционных принципов - единство в их непротиворечии [16, с. 35-40].

Идея бинарности конституционных принципов согласуется с проведенным В.Е. Чиркиным методологически верным неотождествлением социального государства и его одноименной функции. Как указывает ученый, цель социального государства состоит в реализации конституционных гарантий обеспечения достойного уровня жизни и соответствующих социальных благ ${ }^{8}$.

Отметим, что идея баланса бинарных конституционных принципов рассматривается и в других конституционно-правовых сферах. Так, указывая на конституционно обусловленную императивность баланса между ценностями рыночной экономики и конституционными ценностями социального государства, Конституционный суд РФ (далее также - КС) говорит о «социально ориентированной рыночной экономике» ${ }^{9}$. В рамках бюджетного законодательства предлагается, в частности, перейти от финансово-правового патернализма к финансово-правовому инвестированию, где цель обеспечения расходов получателей замещается получением доходов получателей, что означает «коммерциализацию» социальной функции государства и «социализацию» предпринимательской деятельности. Последнее выступает одним из инструментов обеспечения «баланса бинарных конституционных принципов» [11, с. 76-85].

Принципиально не исключая возможность рассмотрения конституционных принципов с изложенных выше «бинарных» позиций, укажем лишь, что ткань конституционной материи значительно сложнее, а изложенный выше подход к анализу конституционных принципов более приемлем и, подчеркнем, весьма желателен с дидактической точки зрения, где соответствующая дихотомия позволяет прояснить глубокое содержательное наполнение каждого из принципов, в то время как конституционная доктрина требует комплексного подхода,

\footnotetext{
8 Чиркин В.Е. Государствоведение. М., 2000. С. 56.

9 Постановления Конституционного суда РФ от 20.12.2010 г. № 22-П, от 14.05.2009 г. № 8-П.
}

сопровождаемого юридическим анализом действия всех других конституционных правоположений.

Так, рассматривая свободу договора и ограничения предпринимательской деятельности, КС указал на требования их адекватности, пропорциональности, соразмерности, а также соответствие целям «защиты основных конституционных ценностей», при котором государственное вмешательство должно «обеспечивать частное и публичное начала в сфере экономической деятельности» ${ }^{10}$, не допустить постановку «под угрозу конституционно защищаемых ценностей» ${ }^{11}$.

Соглашаясь с ценностью конституционных принципов, нельзя забывать и недостатки их правоприменения, являющиеся обратной стороной достоинств: слабая юридическая формализация, как справедливо указывается в научной литературе, зачастую может приводить к политизации принимаемых на их основе решений или государственной идеологизации ${ }^{12}$ [9, с. 265-265], но вместе с тем это чрезвычайно важно для определения вектора государственного развития.

Предварительный вывод 1: конституционньй принизи выступает самостоятельной конституционно защишцаемой иенностью правовой системь России.

\section{II. Конституционно-правовая характеристика пропорциональности как самостоятельного принципа права: юридическое содержание и условия правоприменения}

С учетом сказанного, опираясь на результаты анализа пропорциональности, произведенного ранее [14, c. 165-185, 250-256], считаем возможным подойти к исследованию пропорциональности как самостоятельного конституционного принципа по следующим направлениям:

1) содержание и признаки;

2) процедура и условия правоприменения;

3) критерии определенности и достижимости;

4) телеологическая завершенность и практическая обусловленность.

\section{Первое: содержательные или юридико-онтологические аспекты (признаки)}

Применительно к конституционным принципам как таковым считаем возможным выделить их следующие фундаментальные особенности, а также сопутствующие им признаки принципа конституционной пропорциональности:

1) идеологические начала (справедливость, равенство, гуманизм и т. п.) как фундаментальная основа регламентации конституционных правоотношений; вытекающий отсюда признак исследуемого конституционного принципа - степень достижения (исполнения);

2) высокая степень юридической абстракции, зачастую исключающая формализацию с помощью традиционных для отраслевого законодательства норматив-

\footnotetext{
10 Постановление Конституционного Суда РФ от 16.07.2018 г. № 32-П.

11 Постановление Конституционного Суда РФ от 13.02.2018 г. № 8-П.

12 Нерсесянц В.С. Философия права : учебник для вузов. М. : Норма, 1997. C. $386-387$.
} 
ных правовых формулировок («принцип равенства», «принцип справедливости» и т. п.); признак - отсутствие в тексте Основного закона нормы, раскрывающей содержание конкретного конституционного принципа;

3) непрерывность действия принципа; признак отсутствие дискретности в ходе реализации конституционного принципа во времени;

4) возможность одновременного правоприменения конкурирующих между собой конституционных принципов (например, свобода предпринимательской деятельности и требования социального государства); признак - наличие конституционной неопределенности в определении и выборе единственного принципа, подлежащего применению;

5) абстрактное конституционное предписание благодаря судебному толкованию деконструируется, облекаясь в конкретное конституционное правоположение - формально определенную норму, подлежащую правоприменению; признак - формально-юридический ответ на вопрос о наличии или отсутствии соответствующего субъективного права частного лица или публичного права органа власти;

6) баланс конституционно защищаемых ценностей как конституционно-правовая основа гармонизации применения различных и порой разновекторных конституционных принципов; признак - непротиворечивость избранной модели конституционного праворегулирования.

Изложенные здесь положения в совокупности с рассмотренными в предшествующих разделах работы механизмом и условиями пропорциональности позволяют сделать вывод о том, что применение требований пропорциональности обладает всеми выявленными выше признаками конституционного принципа.

При этом ключевым признаком, предопределяющим особенность пропорциональности как принципа, позволяющим обеспечить указанный выше баланс конституционных ценностей, выступает степень его достижения - пропорциональность реализуемых правовых механизмов, средств и инструментов регулируемым общественным правоотношениям. Взаимосвязь конституционных принципов между собой возможна на основании выделенных выше содержательных юридико-онтологических особенностей и признаков. Гармонизирующим в этом выступает категория баланса конституционно защищаемых ценностей, а процедурой его обеспечения - степень его достижения [14].

Сказанное позволяет теперь подойти ко второму из выделенных выше аспектов рассмотрения принципа пропорциональности - процедуре и условиям применения принципа пропорциональности.

Предварительный вывод 2: приниип пропорииональности выступает одной из фундаментальных правовых основ, регламентирующих конституиионные правоотношения и обладающих высокой степенью юридической абстракиии.

\section{Второе: процедура и условия правоприменения}

Исследование пропорциональности, предпринятое ранее, позволяет утверждать, что содержательные юридико-онтологические особенности рассматриваемо- го принципа находят свое выражение лишь тогда, когда принцип пропорциональности подлежит применению, т. е. в процессе его реализации. Так, раскрытие содержания принципа пропорциональности, в отличие, например, от принципов справедливости, равенства или демократизма, возможно лишь при его соотношении в динамике действия и степени совместного применения с иными конституционными принципами.

Действительно, если, например, демократизм можно раскрыть посредством правовых категории той или иной степени юридической формализации, вне зависимости от реального наличия или отсутствия демократии в конституционной практике государства, то пропорциональность возможно «узреть» только по результатам соответствующей правоприменительной или правореализационной деятельности государства и его органов.

Не случайно в научной литературе принцип пропорциональности раскрывается зачастую как «соразмерность целей и средств всех актов и действий органов публичной власти» [3].

В этом смысле можно утверждать, что принцип пропорциональности обладает процедурно-процессуальным характером: принцип проявляет свое юридическое содержание при соблюдении определенных условий и критериев (процессуальный аспект) в результате непосредственной, последовательной и поэтапной реализации правил и требований (процедурный аспект).

Кроме того, интегративное действие процедурно-процессуального принципа пропорциональности, целью применения которого является обеспечение баланса конституционно защищаемых ценностей, в обязательном порядке требует соотнесения в процессе реализации указанного принципа с действием других конституционных принципов, в том числе равновекторными (бинарными), но не охватывается ими.

В этом смысле пропорциональность проявляется на стыке и в процессе действия иных конституционных принципов и конституционно защищаемых ценностей.

Процедурно-процессуальный характер принципа пропорциональности требует определения элементов, обеспечивающих возможность достижения баланса конституционно защищаемых ценностей - условий, критериев и моделей его правоприменения.

По этой причине нельзя считать юридически безупречным имеющие место в практике Конституционного Суда РФ общие ссылки на использование принципа соразмерности (пропорциональности) без надлежащего изложения аргументов, положенных в основу оценки правил и процедур его применения. Более того, в рамках представленной выше модели действия принципа пропорциональности это будет означать также замещение выявленной ранее дискреции как условия реализации принципа пропорциональности, предопределяющую лишь саму возможность такого правоприменения на дискрецию как непроверяемое и, следовательно, отчасти неограниченное усмотрение.

Очевидно, что подобное применение принципа пропорциональности не будет способствовать укреплению доверия ни к конкретным решениям такого органа, ни к деятельности публичных институтов как таковым. 
Поэтому мнение о том, что последовательное прохождение стадий при проведении теста пропорциональности является излишней «формалистичностью», встречающейся в правовой доктрине и «нормоконтрольной деятельности отдельных конституционных/межгосударственных юрисдикционных органов» ${ }^{13}$, представляется ошибочным. Напротив, процессуальная экономия органа конституционного контроля, о котором говорит Конституционный Суд РФ, допускающая отклонение от прохождения всех стадий и этапов (своеобразное «конституционное пренебрежение»), не может ставить под сомнение объективно признаваемые им «гносеологические мотивы» ${ }^{14}$ справедливости и законности постановляемого Судом решения.

Применение принципа пропорциональности предопределяется возможностью руководствоваться им при определении модели регламентации общественных отношений (законодательная сфера) или разрешении возникших споров (судебная сфера). В основе сказанного лежат дискреционные полномочия.

Юридическая допустимость конституционной дискреции в практической ситуации непосредственного правоприменения во многом будет определяться соотношением между юридической возможностью усмотрения и границами конституционного контроля за его реализацией [12].

Иными словами, применительно к законодательному (представительному) органу государственной власти содержание его юридико-эпистемологического усмотрения будет определяться ответом на вопрос о соотношении, например, конституционного контроля (надзора) со стороны Конституционного Суда и границами собственных конституционных полномочий Парламента.

Юридико-эпистемологическое усмотрение может возникнуть только в случаях юридической неопределенности или, как указывается в зарубежных исследованиях, «нормативной ненадежности» [17, с. 420; 18, с. 215]. Последняя в целом обусловлена объективными пределами познавательных способностей, а в нашем случае пределами познаваемости действия конституционных норм и закрепляемых в законе юридических форм их эффективного обеспечения.

Вопрос об эпистемологической доступности понимания нормативных положений напрямую связан с одной фундаментальной проблемой, получившей в последнее время наиболее яркое олицетворение в сфере процессуального законодательства, а именно - в концепции формально-определенной истины.

Не случайно именно процессуальное законодательство стало сферой правового отражения юридикоэпистемологической неопределенности в праве. На самом деле общественные отношения, урегулированные нормами материального права, как правило, имеют достаточно четкую и безальтернативную определенность: право и обязанность, дозволение и запрет и проч.

\footnotetext{
13 Методологические аспекты конституционного контроля (к 30-ле тию Конституционного Суда Российской Федерации) (одобрено решением Конституционного Суда РФ от 19.10.2021).

14 Там же.
}

Вместе с тем, с учетом эпистемологической невозможности предопределить все вариации предметной жизни человека, социума и государства, значительная роль в регулировании общественных отношений отводится сформулированным в законе принципам и основанным на них процессуальным решениям уполномоченных органов. Именно здесь возрастает роль юридико-эпистемологического усмотрения для разрешения возникшей в практике общественной жизни ситуации правовой неопределенности.

Последнее слово в установлении эмпирических предпосылок в случаях неопределенности остается за законодательной властью. Компетенция законодательного органа по отношению к Конституционному суду может быть квалифицирована не как принцип, а как правило $[17$, c. 426]. Это означает, что именно законодательная власть, а не Конституционный суд, имеет право принимать решения в рамках эпистемологического усмотрения. Следовательно, прямое действие конституционных норм обеспечивается дискреционными полномочиями КС давать соответствующее толкование и разъяснения норм Основного закона, в то время как правомочность самого законодательного органа является лишь следствием предоставленных ему Конституцией дискреционных полномочий - структурной и юридико-эпистемологической дискреции [13].

Вопрос о распределении компетенций решается с помощью простого правила, а не баланса принципов. Это - правило распределения полномочий между законодательным органом и Конституционным судом. Законодательная власть связана только конституцией, в то время как Конституционный суд как судебная власть связан также принятыми в ее исполнение законами.

Действительно, пределы нормотворческого и правоприменительного усмотрения определяются, как указывает Конституционный суд РФ, требованиями соразмерности (пропорциональности) ${ }^{15}$.

Таким образом, условием применения принципа пропорциональности выступает дискреция.

Предварительный вывод 3: неисполнение какихлибо процедурно-проиессуальных элементов, обеспечивающих действия приниипа пропоричональности, их упразднение, в основе которого лежит дискреиия, исключает исполнение приниипа как такового.

\section{Третье: критерии определенности и достижимости}

Для исключения избыточного усложнения во всех случаях реализации принципа пропорциональности считаем допустимым говорить о следующих критериях определенности и достижимости: а) конституционная невозможность пропорциональности; б) конституционная допустимость пропорциональности; в) конституционная необходимость пропорциональности.

Конституиионная невозможность пропорииональности предполагает такое соотношение ценностей, при котором в рамках современного правопонимания

\footnotetext{
15 Методологические аспекты конституционного контроля (к 30-летию Конституционного Суда Российской Федерации) (одобрено решением Конституционного Суда РФ от 19.10.2021).
} 
установление между ними конституционно-правового баланса является неприемлемым и недопустимым. Например, при конкуренции таких конституционных ценностей, как право на жизнь и право на частную собственность, в российской правовой парадигме не может считаться «автоматически» допустимым лишение лица жизни в случае нарушения им границ частной собственности, не сопряженного с посягательствами на жизнь и здоровье собственника. Таким образом, установление в законе разрешения на применение огнестрельного оружия исключительно с целью восстановления нарушения цивилистического права частной собственности будет неприемлемым и недопустимым. Мы имеем ситуацию с ярко выраженной конституционной невозможностью обеспечения пропорциональности указанным правовым инструментарием.

Конституиионная допустимость пропорииональности. В развитии приведенного выше примера предположим, что собственник жилого дома обеспечил применение механизмов, препятствующих проникновению на территорию принадлежащей ему недвижимости, гипотетически исключающих причинение вреда каким-либо случайно попавшим на охраняемую территорию лицам, за исключением тех, кто действует с прямым преступным умыслом, например, в целях наживы (кражи) чужого имущества. Ответ о допустимости подобной конституционной пропорциональности будет поставлен в зависимость от множества квалифицирующих признаков как со стороны действий преступника (был ли умысел направлен только на имущество с целью кражи или также на возможность причинения вреда здоровью и жизни лиц, находящихся на охраняемой территории), так и со стороны титульного владельца: позволяют ли предпринятые им меры в отношении защиты имущества исключить прямое причинение вреда жизни и здоровью расхитителю. Как показывает сложная правоприменительная практика, именно анализ указанных и многих других обстоятельств позволяет в конечном счете определить конституционную возможность - допустимость предпринятых собственником фактических мер, направленных на защиту цивилистических отношений в рамках действующего правового инструментария.

Конституционная необходимость пропоричональности предполагает ситуацию, при которой избранный арсенал правовых средств и инструментов обеспечивает достижение баланса конституционно защищаемых ценностей. Если в первом случае речь шла о невозможности гармоничного обеспечения и защиты порой разновекторных (бинарных) в своей реализации ценностей, а во втором - о принципиальной допустимости избранного направления в защите ценностей, то в данной (третьей) конструкции имеем ситуацию, сопряженную, по сути, с обязательностью применения найденного правового инструментария, обеспечивающего реализацию каждой из ценностей и тем самым достижение соответствующего баланса конституционно защищаемых ценностей.

В рамках рассматриваемого выше примера конституционно необходимыми с точки зрения обеспечения пропорциональности будут, в частности, такие варианты защиты права частной собственности, как запи- рающие и сигнализирующие устройства, привлечение специальных служб, обеспечивающих охрану и т. п.

Так, исключение из матрицы типового разнообразия справедливости не позволяет в должной степени применять пропорциональность к разным группам правоотношений, в том числе с условием особенностей, свойственных российскому отраслевому законодательству. Например, достижение справедливости в отдельных видах гражданских правоотношений, основанных на принципах возмездности и допустимости применения средств самозащиты (коммутативный тип справедливости), может оказаться полностью (или в части) неприемлемой в правоотношениях, регулируемых нормами уголовного или административного законодательства.

Предварительный вывод 4: спорадическое исполнение (применение) отдельных критериев и условий не только разрушает доктринальную завершенность приниипа пропорииональности как такового, но, что самое главное, не позволяет обеспечить механизм его действия в иелом.

\section{Четвертое: телеологическая завериенность и прак- тическая обусловленность}

Достижением цели правового регулирования, как уже неоднократно было указано, выступает баланс конституционно защищаемых ценностей.

В процессе реализации указанного целеполагания принцип пропорциональности подспудно проявляет дополнительное специфическое качество, состоящее в итогах его применения. Так, если неисполнение «классических» принципов законности, справедливости и т. п. с очевидностью влечет за собой отмену соответствующих действий и решений, в том числе признание нормативных правовых актов или их частей не соответствующими Конституции РФ, неприменение принципа пропорциональности императивно таких последствий не влечет, поскольку в этой ситуации нельзя говорить об отсутствии пропорциональности.

Пропорциональность ограничений, запретов и обязанностей констатируется и гарантируется лишь по результатам применения исследуемого принципа, но вне его - может только предположительно ожидаться или отрицаться. Поэтому качество пропорциональности имеет предварительное, предупреждающее значение возможность исключения в последующем негативных последствий, связанных с введением непропорциональных правовых средств и механизмов.

Предварительный вывод 5: применение приниипа пропорииональности носит упреждающий (пруденциальный) по отношению к обеспечению баланса конституицонно зашишзаемых иенностей характер; указанное качество обеспечивает снижение рисков неконституиионного регулирования соответствующих правоотношений.

\section{III. Конституционно-правовые особенности (условия) реализации принципа пропорциональности: матрица элементов пропорциональности}

Рассмотренные нами выше категории, признаки и условия обеспечения баланса конституционно защища- 
Матрииа элементов пропорииональности: условия конституционной пропорииональности

\begin{tabular}{|c|c|c|c|c|c|c|c|c|c|}
\hline \multicolumn{10}{|c|}{ баланс конституционно защищаемых ценностей } \\
\hline $\begin{array}{c}\text { критерии } \\
\text { пропорциональности }\end{array}$ & \multicolumn{3}{|c|}{$\begin{array}{c}\text { справедливость } \\
\text { уравнивающая } \\
\text { (синаллагматическая) }\end{array}$} & \multicolumn{3}{|c|}{$\begin{array}{c}\text { справедливость } \\
\text { распределяющая } \\
\text { (дистрибутивная) }\end{array}$} & \multicolumn{3}{|c|}{$\begin{array}{c}\text { справедливость меновая } \\
\text { (коммутативная) }\end{array}$} \\
\hline законность цели & да/нет & да/нет & да/нет & да/нет & да/нет & да/нет & да/нет & да/нет & да/нет \\
\hline пригодность & да/нет & да/нет & да/нет & да/нет & да/нет & да/нет & да/нет & да/нет & да/нет \\
\hline $\begin{array}{c}\text { адекватность } \\
\text { [необходимость и } \\
\text { соразмерность] }\end{array}$ & да/нет & да/нет & да/нет & да/нет & да/нет & да/нет & да/нет & да/нет & да/нет \\
\hline $\begin{array}{c}\text { правовые } \\
\text { константы }\end{array}$ & [a] & [6] & [в] & [a] & [6] & [в] & [a] & [6] & [в] \\
\hline
\end{tabular}

* а) конституционная невозможность; б) конституционная допустимость; в) конституционная необходимость

емых ценностей могут быть сведены в комплексную матрицу, демонстрирующую собственно действие принципа конституционной пропорциональности.

Включение указанных элементов в матрицу позволяет обеспечивать самые разные способы их соотношения, например, баланс между материальными принципами, включая эпистемологические неопределенности, и процессуально-процедурными принципами, компетенцией и судебным контролем (надзором) либо между компетенцией законодательного органа и материальными принципами, или, как продолжение, баланса между эпистемологической неопределенностью и прямыми нормами Основного закона (табл.1).

Функциональное использование представлений матрицы рассмотрим на примере действия принципа пропорциональности в правоотношениях, связанных с защитой жизни и здоровья гражданина как основной конституционно защищаемой ценности.

В качестве примера проанализируем нормы статьи 1083 ГК РФ, ставшие предметом неоднократного рассмотрения Конституционным Судом РФ, а именно конституционность абзаца второго пункта 2 указанной статьи, в соответствии с которым даже грубая неосторожность потерпевшего и отсутствие вины причинителя не является основанием для отказа в возмещении вреда при причинении вреда жизни или здоровью гражданина.

По мнению заявителей, положение гражданского законодательства, при котором на владельца транспортного средства, являющегося при этом добросовестным участником дорожного движения, накладывается безусловная обязанность по возмещению вреда, что «нарушает баланс прав сторон деликтного обязательства» ${ }^{16}$.

Конституционный суд РФ дал иную оценку данной ситуации, указав, что конституционность исследуемых правоположений зависит от ряда обстоятельств:

а) общее правило, изложенное в пункте 2 статьи 1064 ГК РФ о том, что лицо, причинившее вред, освобождается от возмещения вреда, если докажет, что вред

16 Определение Конституционного Суда РФ от 19.12.2019 г. № 3429-О. причинен не по его вине, имеет здесь же установленное исключение: законом может быть предусмотрено возмещение вреда и при отсутствии вины причинителя вреда ${ }^{17}$;

б) положения статьи 1079 ГК РФ предусматривают, что ответственность за вред, причиненный деятельностью, создающей повышенную опасность для окружающих, наступает независимо от вины причинителя вреда; указанная норма представляет собой один из законодательно предусмотренных случаев отступления от принципа вины, при котором ответственность возлагается вне зависимости от ее присутствия у причинителя вреда и поэтому не может рассматриваться как противоречащая части третьей статьи 55 Конституции РФ, допускающей ограничение конституционных прав и свобод федеральным законом в целях защиты здоровья, прав и законных интересов других лиц ${ }^{18}$;

в) пункт 2 статьи 1083 ГК РФ в системной связи с рассмотренными положениями статьи 1079 ГК РФ позволяют говорить лишь о двух случаях уменьшения размера возмещения вреда, возникновению или увеличению которого способствовала грубая неосторожность потерпевшего ${ }^{19}$ :

- наличие грубой неосторожности со стороны потерпевшего и, обязательно, наличие вины причинителя вреда;

- установление факта грубой неосторожности, но отсутствие вины причинителя вреда; в данной ситуации допускается не только уменьшение размера возмещения, но и полный отказ в возмещении, если иное не установлено законом.

При этом, как указывает КС РФ, освобождение от ответственности по усмотрению суда при осуществлении правосудия основано на имманентно присущей судебной власти дискреционности, основанной на само-

\footnotetext{
17 Определение Конституционного Суда РФ от 24.11.2016 г. № 2454О; см. также: постановление Конституционного Суда РФ от 15.07.2009 г. № 13-П.

18 Определение Конституционного Суда РФ от 23.06.2005 № 261-О; постановление Конституционного Суда РФ от 25.01.2001 г. № 1-П.

19 Определение Конституционного Суда Российской Федерации от 04.10.2012 г. № 1833-О.
} 
стоятельности судебной власти, предусмотренной статьей 10 Конституции РФ $\Phi^{20}$.

В связи с изложенным, ссылаясь на проводимую в Российской Федерации политику правового и социального государства, Конституционный суд РФ указал, что нормы действующего законодательства воплощают основанный на «принципе пропорциональности баланс субъективных прав причинителя вреда, осуществляющего деятельность, связанную с повышенной опасностью для окружающих, с одной стороны, и потерпевшего, проявившего грубую неосторожность, - с другой, а потому данные законоположения не могут рассматриваться как нарушающие права заявителя, закрепленные в статьях 17 (часть 3), 19 (часть 2), 45 (часть 1) и 55 Конституции Российской Федерации» ${ }^{21}$.

Предварительный вывод 6: невозможно обеспечить реализацию правовой пропорииональности и баланса конституиионно защищаемых иенностей в случае исключения каких-либо критериев (законности, пригодности, адекватности); основополагающим здесь выступают требования в последовательном соблюдении (оценке и анализе) выявленных критериев в степени их достижения (реализации), которье можно агрегировать в единую матрииу элементом (условий) пропорииональности.

\section{IV. Практические аспекты применения принципа пропорциональности при установлении баланса конституционно значимых ценностей}

Попытаемся рассмотреть приведенные выше конституционные правоположения с учетом предложенной матрицы принципа пропорциональности.

Являясь безусловной базовой конституционно защищаемой ценностью, право на жизнь не может быть заменено или замещено в рамках ни синаллагматической, ни распределяющей моделей справедливости. Как уже было ранее представлено, правило талиона, подлежащее применению в модели уравнивающей или ретрибутивной справедливости, в качестве основного механизма воздаяния, восстанавливающего попранную справедливость (в нашем случае - жизнь за жизнь), является не только архаичным, но и выходящим за рамки современного понимания гуманизма. Модель распределяющей справедливости также не может быть применена, поскольку при ее использовании мы бы столкнулись с необходимостью сопоставления значения ценности жизни в зависимости от заслуг и достижений того или иного человека и последующего за этим логически необходимого признания высокой важности жизни конкретного лица по сравнению с другим человеком. Подобные позиции также не могут быть допустимыми в связи с их естественно-правовой, конституционной неприемлемостью.

Третья модель выступает единственно возможной, поскольку она, с одной стороны, исключает варианты прямого математического или физиологического замещения ценности жизни (утраченного здоровья) одного

\footnotetext{
20 Определение Конституционного Суда РФ от 19.05.2009 г. № 816-О-О.

21 Определение Конституционного Суда РФ от 19.12.2019 г. № 3429-О.
}

лица другому как субъективного права потерпевшего, а с другой стороны, предполагает введение компенсаторных механизмов, направленных на восстановление вреда, причиненного здоровью в качестве безусловной обязанности со стороны причинителя вреда.

Переходя к квалификации критериев пропорциональности на предмет их невозможного, допустимого или необходимого, получаем следующее:

- законность цели - защита жизни и здоровья выступает фундаментальной конституционно защищаемой ценностью, поэтому установление каких-либо компенсаторных механизмов выступает безальтернативно обязательным, что в рамках нашей матрицы соответствует правовой константе «конституционно необходимой» [«да»];

- пригодность - правовой механизм (финансовой или иной материально-денежной) компенсации следует рассматривать как вполне пригодный, по сравнению, например, с лишением жизни или здоровья причинителя вреда [«да»];

- адекватность как консолидация необходимости и соразмерности - финансовый способ компенсации вреда, действительно, минимальным образом ограничивает право лица при достижении обязательного при содействии государства публично-правовой цели восстановления справедливости (необходимость); кроме того, использование материального замещения позволяет говорить, что ущерб, причиненный интересам частного лица, пропорционален полученной общественной (публичной) пользе от введенного ограничения (соразмерность) [«да»].

Говоря об ущербе, подлежащем оценке в рамках принципа пропорциональности, следует уточнить, что под таковым следует понимать не только материальное выражение вреда, но и другие отрицательные последствия: моральный вред, чувства унижения и душевного расстройства ${ }^{22}$.

Применительно к рассматриваемому казусу матрица будет выглядеть следующим образом (табл. 2).

Таким образом, вводимое законодателем правовое регулирование, которое будет отвечать выявленным здесь критериальным позициям (маркерам в соответствующих графах и ячейках), следует считать соответствующим конституционным предписаниям, и наоборот: нормы законодательства, квалификация которых повлечет изменение «идеальных» позиций их проставление - в иных критериальных позициях, следует подвергнуть на анализ их конституционности ввиду возможного отклонения от исполнения принципа пропорциональности.

Например, если в качестве возмещения вреда, причиненного жизни или здоровью, вместо компенсации законодатель предусмотрит административную или уголовную ответственность (при тех же условиях: наличие грубой неосторожности со стороны потерпевшего и отсутствие вины причинителя вреда), то, помимо

\footnotetext{
Пункт 10 Доклада Специального докладчика по вопросу о пытках и других жестоких, бесчеловечных или унижающих достоинство видах обращения и наказания. Применение силы, не связанное с лишением свободы, и запрет на пытки и другие жестокие, бесчеловечные или унижающие достоинство виды обращения и наказания. Размещен 20 июля 2017 года. А/72/178.
} 
Матрииа элементов пропорииональности (пример 1)

баланс конституционно защищаемых ценностей

\begin{tabular}{|c|c|c|c|}
\hline критерии пропорциональности & \multicolumn{2}{|c|}{ справедливость меновая (коммутативная) } \\
\hline законность цели & нет & нет & да \\
\hline пригодность & нет & нет & да \\
\hline адекватность & нет & нет & [в] \\
\hline [необходимость и соразмерность]
\end{tabular}

Матрииа элементов пропорииональности (пример 2)

\begin{tabular}{|c|c|c|c|}
\hline \multicolumn{3}{|c|}{ баланс конституционно защищаемых ценностей } \\
\hline критерии пропорциональности & \multicolumn{2}{|c|}{ справедливость меновая (коммутативная) } \\
\hline законность цели & нет & нет & на \\
\hline пригодность & нет & да & нет \\
\hline адекватность & нет & {$[$ а ] } & {$[$ в] } \\
\hline [необхдимость и соразмерность]
\end{tabular}

доктринально-отраслевых проблем (отсутствие вины в составе правонарушения или преступления), мы смещаем критерий адекватности с позиции необходимости в сторону «правовой невозможности» [a], поскольку сам по себе факт квалификации деяния в качестве уголовного или административного деяния никоим образом в этой ситуации не восстанавливает вред, причиненный здоровью лица.

Иными словами, в этом случае такой критерий конституционной пропорциональности не выполняется и свидетельствует о несоразмерности выбранного механизма обеспечения баланса конституционно защищаемых ценностей.

Усложним ситуацию: к административному или уголовному наказанию добавляем материальную компенсацию причиненного вреда жизни и здоровью. Сам по себе подобный юридический состав является вполне приемлемым, но при отсутствии вины со стороны причинителя вреда будет свидетельствовать лишь о «допустимости» [б] - его отчасти необходимым, но недостаточно соразмерным, в отличии от первого рассмотренного варианта - вполне адекватным: необходимым [в].

Сравнительно другим образом следует оценивать пропорциональность защиты, предусмотренной рассматриваемыми положениями статьи 1083 ГК РФ, в ситуации, когда речь идет не о возмещении вреда жизни или здоровью человека, но иным конституционно защищаемым ценностям.

Так, исследуя цивилистические положения, предусмотренные главой 59 ГК РФ «Обязательства вследствие причинения вреда» применительно к отношениям, возникающим в связи с реквизицией, выступающей способом правомерного изъятия имущества в ситуациях, связанных с распространением особо опасных болезней животных, Конституционный суд РФ совершенно справедливо соотносит их с имущественными и по этой причине признает неконституционным наличие в системе действующего законодательства неопределенности «в вопросе об учете при определении и осуществлении выплаты собственнику стоимости животных или продуктов животноводства, изъятых у него при ликвидации очагов особо опасных болезней животных» ${ }^{23}$.

Обратим внимание на принципиальное различие: если в ситуации с оценкой вреда, причиненного жизни или здоровью лица, подобная ситуация является обоснованной и разрешаемой по усмотрению суда на основании его дискреционных полномочий, то в случае с имуществом - не соответствующим Конституции РФ.

Для подобной ситуации матрица конституционной пропорциональности до признания имеющей место практике правоприменения неконституционной, т. е. в отсутствии механизма, позволяющего определить ущерб, выглядела бы таким образом (табл. 3).

Принцип пропорциональности не соблюден применительно к критерию адекватности: денежная компенсация является необходимой, но поскольку отсутствуют методики ее расчета - она может быть недостаточно соразмерной размерам причиненного вреда: допустима [6], но не «конституционна необходима», поскольку любое имущественное благо, любая вещь (животные относятся именно к этой категории), в отличии от нематериальных ценностей - здоровья или жизни

23 Постановление Конституционного Суда РФ от 08.07.2021 г. № 33-П. 
человека, выступающей наивысшей конституционно защищаемой ценностью, - не может иметь императивную модель подсчета ее «стоимости», потому что требует охвата в своей оценке множества самых различных, зачастую математически неформализуемых обстоятельств в принципе. Последнее в настоящий момент представляется единственно возможным и конституционно допустимым достигнуть только в рамках правоприменительной дискреции суда.

Как вытекает из судебной правоприменительной практики, оценка пропорциональности производится с учетом обстоятельств конкретного дела не только с учетом значимости защищаемых законом ценностей (здоровья, жизни и т. п.), но и с учетом имеющих для рассмотрения данного дела юридически значимых субъективных фактов и характеристик лица: пола, возраста, состояния здоровья, признаков деликтного поведения лица ${ }^{24}$.

Таким образом, процедурно-процессуальный характер принципа пропорциональности проявляется, с одной стороны, в обязательной оценке взаимодействия с другими конституционными принципами на базе взаимообусловленного юридически и логически сочетаемых между собой критериев и моделей (условия пропорциональности, представленные в изложенной выше матрице) - процессуальный момент, с другой стороны, в последовательном исполнении соответствующих обязательных этапов (теста пропорциональности) - процедурный момент.

Принцип пропорциональности позволяет установить адекватность способов и границ реализации прав и законных интересов, влияет на определение непосредственных форм и процедур, инструментов и механизмов законотворчества и правоприменения.

\section{Выводы}

Принцип пропорциональности выступает одной из фундаментальных правовых основ, регламентирующих конституционные правоотношения и обладающих высокой степенью юридической абстракции, его содержанием является процедурно-процессуальная модель применения условий и критериев достижения справедливости, реализация которой носит пруденциальный по отношению к обеспечению баланса конституционно защищаемых ценностей характер.
Исполнение процедурно-процессуальной модели является не только фактором правоприменения принципа пропорциональности, но и абсолютно необходимым условием его реализации. В последнем состоит основополагающее отличие содержания принципа пропорциональности от других конституционных принципов права. С учетом конституционной пропорциональности как самостоятельного феномена правовой действительности принцип пропорциональности обретает свое содержание исключительно в процессе его реализации. Последнее предполагает последовательное соблюдение условий и критериев, представленных в изложенной выше авторской матрице пропорциональности.

Спорадическое исполнение (применение) отдельных критериев и условий не позволяет обеспечить механизм его действия в целом. Исключение из матрицы каких-либо элементов не позволяет в должной степени применять пропорциональность в соответствующих видах правоотношений.

Основополагающими здесь выступают требования последовательного соблюдения (оценки и анализа) выявленных критериев в степени их достижения (реатизации), агрегированных в единой матриие элементом (условий) пропорииональности.

Неисполнение каких-либо процедурно-процессуальных элементов, обеспечивающих действия принципа пропорциональности, их упразднение исключает исполнение принципа как такового. Иное применение принципа пропорциональности не будет способствовать укреплению доверия ни к конкретным решениям такого органа, ни к деятельности публичных институтов как таковым.

Как видим, принцип пропорциональности обладает спецификой собственного юридического содержания, отличающего его не только от юридических норм, но и от особенностей правовой реализации других конституционных принципов. Вероятно, следует признать, что принцип пропорциональности выступает одной из «интегративных структур», о которой писал в свое время С.С. Алексеев, признавая за правом единую систему, в которой, помимо норм-предписаний и «классических» принципов, существуют иные «частицы», являющиеся органическими элементами нормативной системы в целом.

\footnotetext{
24 Обобщение практики и правовых позиций международных договорных и внедоговорных органов, действующих в сфере защиты прав и свобод человека, по вопросам защиты права лица на жизнь (утв. Президиумом Верховного Суда РФ) // Текст документа приведен в соответствии с публикацией на сайте https://vsrf.ru/ по состоянию на 23.06.2021.
} 


\section{Литература}

1. Азми Д.М. Правовое значение и соотношение понятий «процесс» и «процедура» // Адвокат. 2009. № 12. С. 13-20.

2. Алебастрова И.А. Конституционные принципы: проблемы юридической природы и эффективности реализации // Конституционное и муниципальное право. 2007. № 7. С. 5-12.

3. Алебастрова И.А. Конституционные принципы: форма выражения, место в системе права и его источников // Конституционное и муниципальное право. 2007. № 8. С. 12-16.

4. Барабаш А.С. О содержании понятия «принцип» в разных отраслях права // Российский юридический журнал. 2019 . № 2. C. $98-107$.

5. Гаджиев Г.А. Конституционная экономика и рациональность в конституционном праве // Ежегодник конституционной экономики. 2018 / Отв. ред. С.А. Авакьян, П.Д. Баренбойм, В.В. Комарова. М. : ЛУМ, 2018. С. 18-42.

6. аджиев Г.А. О принципе пропорциональности и конституционной кассации // Судья. 2019. № 7. С. 56-74.

7. Гаджиев Г.А. Принципы права и право из принципов // Сравнительное конституционное обозрение. 2008. № 2. С. 22 - 45.

8. Гемонова Е.А. Соотношение принципов права и норм права на примере нормативного правового договора // Российская юстиция. 2019. № 11. С. 5-8.

9. Давид Р., Жоффре-Спинози К. Основные правовые системы современности. М., 1996. 400 с.

10. Крусс В. И. Российская конституционная аксиология: актуальность и перспективы // Конституционное и муниципальное право. 2007. № 2. С. 7-14.

11. Омелехина Н.В. Обеспечительная функция публичных финансов в контексте конституционных принципов социального государства // Журнал российского права. 2021. № 8. С. 76-85.

12. Хорунжий С.Н. Общероссийское голосование как субсидиарная форма реализации конституционного права граждан на участие в управлении делами государства // Мониторинг правоприменения. 2020. № 3(36). С. 9-15. DOI: 10.21681/22260692-2020-3-9-15.

13. Хорунжий С.Н. Дискреционные полномочия федерального законодателя в сфере электоральных отношений: конституционно-правовой аспект / Гражданин. Выборы. Власть. 2021. № 3(21). С. 52-65.

14. Хорунжий С.Н. Правовой баланс как самостоятельная юридическая ценность: механизмы его обеспечения и регулирования. Воронеж : Изд-во ВГУ, 2019. 526 с.

15. Шустров Д.Г. Прирученный Левиафан: государство как объект конституционно-правового регулирования. СПб., 2014. $434 \mathrm{c}$.

16. Якимова Е.М. Проблема бинарности конституционных принципов свободы предпринимательской деятельности и социального государства // Право и экономика. 2019. № 3. С. 35-40.

17. Alexy R. A Theory of Constitutional Rights. (1986). Oxford, 2010.

18. Alexy R. Rechtsregeln und Rechtsprinzipien. R. Alexy/H.-J. Koch/ L. Kuhlen/H. Rüßmann, Elemente einer juristischen Begründungslehre, Baden-Baden 2003, S. 217-233.

19. Grundmann S. Constitutional values and European contract law. The Netherlands, 2008.

20. Mohapatra A. K. Basic objectives and values of Indian Constitution // Orissa Review. 2011. January.

Рецензент: Захариев Сергей Иванович, доктор юридических наук, профессор, заведующий кафедрой адвокатуры и правоохранительной деятельности РГСУ, г. Москва, Российская Федераиия.

E-mail: sergeyivz@yandex.ru

\section{Proportionality as an Independent Constitutional PRinciple OF THE RUSSIAN FEDERATION}

\section{S. Khorunzhii ${ }^{25}$}

Keywords: constitutional principle, proportionality, necessity, suitability, balance of constitutionally protected values, deconstruction.

\section{Abstract.}

Purpose of the work: analysing and identifying the features of proportionality as an independent constitutional principle of law, setting up a matrix of the proportionality elements ensuring the conditions for implementing constitutional proportionality.

Methods of study: the scientific doctrinal, legal dogmatic, comparative legal, and hermeneutic methods.

\footnotetext{
25 Sergei Khorunzhii, Secretary of the Voronezh Oblast Election Commission, Ph.D. (Law), Associate Professor at the Department of Constitutional and Municipal Law of the Law Faculty of Voronezh State University, Voronezh, Russian Federation. E-mail: snhor@mail.ru
} 


\section{Proportionality as an independent constitutional principle of the Russian Federation}

Results of study: it was established that the proportionality principle is independent, it is one of the basic legal foundations regulating constitutional legal relations which possess a high degree of legal abstraction whose content is a procedural model of using the conditions and criteria for achieving justice the implementation of which is of prudential nature in relation to ensuring the balance of constitutionally protected values.

The execution of the procedural model becomes not only a fact of law enforcement of the proportionality principle but is a condition for its implementation. This is the fundamental difference between the content of the proportionality principle and other constitutional law principles. Considering constitutional proportionality as an independent phenomenon of legal reality, the proportionality principle acquires its content exclusively in the process of its implementation. The latter presumes a consistent observance of the conditions and criteria presented in the said proportionality matrix.

The categories, features and conditions for ensuring the balance of constitutionally protected values were brought together in a comprehensive matrix demonstrating the operation of the constitutional proportionality principle as such.

The author's model of the proportionality matrix presented in the paper allows to ensure a balance between the material and procedural principles, the competence of the public agency and judicial control (oversight), epistemological uncertainty and explicit provisions of the Constitution.

The proportionality principle detects the adequacy of the ways and boundaries of implementing rights and legitimate interests, affects the definition of direct forms and procedures, tools and mechanisms of law-making and law enforcement.

\section{References}

1. Azmi D.M. Pravovoe znachenie i sootnoshenie poniatii "protsess" i "protsedura". Advokat, 2009, No. 12, pp. 13-20.

2. Alebastrova I.A. Konstitutsionnye printsipy: problemy iuridicheskoi prirody i effektivnosti realizatsii. Konstitutsionnoe i munitsipal'noe pravo, 2007, No. 7, pp. 5-12.

3. Alebastrova I.A. Konstitutsionnye printsipy: forma vyrazheniia, mesto v sisteme prava i ego istochnikov. Konstitutsionnoe i munitsipal'noe pravo, 2007, No. 8, pp. 12-16.

4. Barabash A.S. O soderzhanii poniatiia "printsip” v raznykh otrasliakh prava. Rossiiskii iuridicheskii zhurnal, 2019, No. 2, pp. 98-107.

5. Gadzhiev G.A. Konstitutsionnaia ekonomika i ratsional'nost' v konstitutsionnom prave. Ezhegodnik konstitutsionnoi ekonomiki, 2018. Otv. red. S.A. Avak'ian, P.D. Barenboim, V.V. Komarova. M. : LUM, 2018, pp. 18-42.

6. Gadzhiev G.A. O printsipe proportsional'nosti i konstitutsionnoi kassatsii. Sud'ia, 2019, No. 7, pp. 56-74.

7. Gadzhiev G.A. Printsipy prava i pravo iz printsipov. Sravnitel'noe konstitutsionnoe obozrenie, 2008, No. 2, pp. 22-45.

8. Gemonova E.A. Sootnoshenie printsipov prava i norm prava na primere normativnogo pravovogo dogovora. Rossiiskaia iustitsiia, 2019, No. 11, pp. 5-8.

9. David R., Zhoffre-Spinozi K. Osnovnye pravovye sistemy sovremennosti. M., 1996. 400 pp.

10. Kruss V. I. Rossiiskaia konstitutsionnaia aksiologiia: aktual'nost' i perspektivy. Konstitutsionnoe i munitsipal'noe pravo, 2007, No. 2, pp. 7-14.

11. Omelekhina N.V. Obespechitel'naia funktsiia publichnykh finansov v kontekste konstitutsionnykh printsipov sotsial'nogo gosudarstva. Zhurnal rossiiskogo prava, 2021, No. 8, pp. 76-85.

12. Khorunzhii S.N. Obshcherossiiskoe golosovanie kak subsidiarnaia forma realizatsii konstitutsionnogo prava grazhdan na uchastie $\mathrm{v}$ upravlenii delami gosudarstva. Monitoring pravoprimeneniia, 2020, No. 3(36), pp. 9-15. DOI: 10.21681/2226-0692-2020-3-9-15.

13. Khorunzhii S.N. Diskretsionnye polnomochiia federal'nogo zakonodatelia v sfere elektoral'nykh otnoshenii: konstitutsionno-pravovoi aspekt. Grazhdanin. Vybory. Vlast', 2021, No. 3(21), pp. 52-65.

14. Khorunzhii S.N. Pravovoi balans kak samostoiatel'naia iuridicheskaia tsennost': mekhanizmy ego obespecheniia i regulirovaniia. Voronezh : Izd-vo VGU, 2019. 526 pp.

15. Shustrov D.G. Priruchennyi Leviafan: gosudarstvo kak ob"ekt konstitutsionno-pravovogo regulirovaniia. SPb., 2014. 434 pp.

16. Iakimova E.M. Problema binarnosti konstitutsionnykh printsipov svobody predprinimatel'skoi deiatel'nosti i sotsial'nogo gosudarstva. Pravo i ekonomika, 2019, No. 3, pp. 35-40.

17. Alexy R. A Theory of Constitutional Rights. (1986). Oxford, 2010.

18. Alexy R. Rechtsregeln und Rechtsprinzipien. R. Alexy/H.-J. Koch/ L. Kuhlen/H. Rüßmann, Elemente einer juristischen Begründungslehre, Baden-Baden 2003, S. 217-233.

19. Grundmann S. Constitutional values and European contract law. The Netherlands, 2008.

20. Mohapatra A. K. Basic objectives and values of Indian Constitution. Orissa Review. 2011. January.

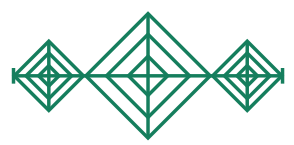




\section{РЕАЛИЗАЦИЯ «РЕГУЛЯТОРНОЙ ГИЛЬОТИНЫ》 НА РЕГИОНАЛЬНОМ И МУНИЦИПАЛЬНОМ УРОВНЯХ}

Андреечев И. С. ${ }^{1}$

Ключевые слова: контрольно-надзорная деятельность, обязательные требования, «регуляторная гильотина», установление обязательных требований, оценка применения обязательных требований, действие обязательных требований, оценка регулирующего воздействия, оценка фактического воздействия.

\section{Аннотация.}

Цель статьи: анализ внедрения и реализации механизмов «регуляторной гильотины» на региональном и муниципальном уровнях, учитывая значимость совершенствования контрольно-надзорной деятельности и данной правотворческой технологии.

Методы исследования: исследование проводилось с использованием формально-юридического, сравнительно-правового и системного методов.

Результаты исследования: автор показал наличие существенных недостатков в правовой модели «регуляторной гильотины» на региональном и муниципальном уровнях в Федеральном законе “Об обязательных требованиях в Российской Федерации» и иных федеральных законах, а также в практике ее внедрения и применения в субъектах Российской Федерации и муниципальных образованиях. В статье сформулированы предложения по совершенствованию федерального законодательства в целях снижения дифференциации регионального и муниципального правового регулирования, его синхронизации и унификации с федеральным регулированием установления и оценки применения обязательных требований, а также по методическому обеспечению такой работы.

DOI: 10.21681/2226-0692-2021-4-21-30

\section{Введение}

$\mathrm{H}$ зорной деятельности, связанный со вступлением в силу федеральных законов от 31 июля 2020 г. № 247-Ф3 «Об обязательных требованиях в Российской Федерации»² (далее - Закон об обязательных требованиях) и № 248Ф3 «О государственном контроле (надзоре) и муниципальном контроле в Российской Федерации» ${ }^{3}$, обуславливает исследование различных аспектов его реализации, включая такое важнейшее направление реформы, как систематизация и актуализация обязательных требований, в том числе исключение устаревших, дублирующих и избыточных обязательных требований [7, с. 34]. Нельзя не согласиться с мнением А.Б. Дидикина о наличии потребности в осмыслении принципов и правовых средств оценки обязательных требований с точки зрения практики нормотворчества [3, с. 4].

«Регуляторная гильотина» рассматривается как инструмент масштабного пересмотра и отмены нормативных правовых актов (далее также - нормативный акт), негативно влияющих на бизнес-климат и регуляторную среду. Целью ее реализации является тотальный

2 Собрание законодательства Российской Федерации. 2020. № 31. Ч. І. Ст. 5007.

3 Собрание законодательства Российской Федерации. 2020. № 31. Ч. І. Ст. 5007. пересмотр обязательных требований с широким участием предпринимательского и экспертного сообществ, а ее задача - создать в сферах регулирования новую систему понятных и четких требований к хозяйствующим субъектам, снять избыточную административную нагрузку на субъекты предпринимательской деятельности и снизить риски причинения вреда охраняемым ценностям ${ }^{4}$.

Учитывая принцип разграничения предметов ведения и полномочий между органами государственной власти Российской Федерации, субъектами Российской Федерации (далее - субъекты РФ) и органами местного самоуправления, отдельного внимания требует оценка внедрения «регулярной гильотины» на региональном и муниципальном уровнях. Принимая во внимание круг вопросов, регулируемых региональными и муниципальными актами, такие акты не могут быть исключены из сферы «регуляторной гильотины». За нарушение таких актов законами субъектов РФ устанавливается административная ответственность, а оценка их соблюдения осуществляется в ходе регионального государ-

\footnotetext{
4 Механизм «регуляторной гильотины». URL: http://www.economy. gov.ru/material/directions/gosudarstvennoe_upravlenie/mehanizm_ regulyatornoy_gilotiny (дата обращения: 10.09.2021).
}

\footnotetext{
Андреечев Игорь Сергеевич, заместитель руководителя администрации - директор правового департамента администрации Губернатора Архангельской области и Правительства Архангельской области, г. Архангельск, Российская Федерация. E-mail: andreechev@dvinaland.ru
} 
ственного контроля (надзора) и муниципального контроля, привлечения к административной ответственности, предоставления разрешений. Если итоги «регуляторной гильотины» на федеральном уровне видны экспертам и общественности, то этого нельзя сказать про ее результаты на региональном и муниципальном уровнях. Такой мониторинг не проводится. По состоянию на 10 сентября 2021 г. на федеральном уровне отменено более 3 тыс. актов, принято практически 450 актов $^{5}$; один из результатов «гильотины» - систематизация законодательства, отмена массива старых неактуальных норм и актуализация правовых актов. Такая задача актуальна для субъектов РФ и муниципальных образований, также накопивших массив неактуальных актов.

Внедрение правил установления и оценки применения обязательных требований на региональном и муниципальном уровнях не является самоцелью или панацеей исключения всех дефектов в правотворчестве. Их применение следует расценивать как одну из передовых и перспективных правотворческих технологий, которые позволяют качественно улучшить нормативное правовое регулирование. Такую задачу выполняют и иные правотворческие технологии - антикоррупционная экспертиза, мониторинг законодательства и правоприменения, экспертиза, оценка регулирующего и фактического воздействия и т. д., которые подробно оценены в юридической литературе [2]. Указанные технологии последовательно вводились на федеральном, региональном и муниципальном уровнях.

Прошедший со дня принятия Закона № 247-ФЗ период позволяет оценить внедрение механизмов установления и оценки применения обязательных требований, «регуляторной гильотины» в субъектах РФ и муниципальных образованиях 6 , а также внести предложения, направленные на их совершенствование. Комплексные исследования внедрения "регуляторной гильотины» в субъектах РФ и муниципальных образованиях, основанные на анализе нормотворческой практике, не проводились. Отдельные публикации основаны на анализе норм Закона об обязательных требованиях [8], не учитывая появившиеся нормотворческие практики.

\section{1. Установление и оценка применения обязательных требований}

Нормативные акты субъектов РФ и муниципальные нормативные акты включены в круг нормативных правовых актов, устанавливающих обязательные требования (ч. 1 ст. 2 Закона об обязательных требованиях). Порядок установления и оценки применения обязательных требований, устанавливаемых региональными и муниципальными нормативными актами, определяется указанными актами (ч. 5 ст. 2 Закона об обязательных требованиях). Данный порядок должен утверждаться на основании Федеральных законов от 6 октября 1999 г. № 184-Ф3 «Об общих принципах организации законода-

\footnotetext{
Статистика «регуляторной гильотины». URL: https://knd.ac.gov.ru/ analytics (дата обращения: 10.09.2021).

6 В статье анализ региональных и муниципальных актов проведен с использованием СПС «КонсультантПлюс: Регионы» (по состоянию на 10.09.2021).
}

тельных (представительных) и исполнительных органов государственной власти субъектов Российской Федерации» (далее - Закон № 184-Ф3)7 и от 6 октября 2003 № 131-Ф3 «Об общих принципах организации местного самоуправления в Российской Федерации» (далее - За-

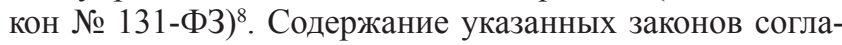
совано с Законом об обязательных требованиях с 1 июля 2021 г. $^{9}$ и в них включены нормы, касающиеся порядка установления и оценки применения обязательных требований (п. 5 ст. 26.3-3 Закона № 184-ФЗ и ч. 6.1 ст. 7 Закона № 131-Ф3).

Анализ региональных и муниципальных актов свидетельствует, что такие механизмы все еще введены в небольшом числе субъектов РФ и муниципальных образований. Причины этого кроются в концепции Закона об обязательных требованиях, недостаточном методическом обеспечении внедрения данных процедур на региональном и муниципальном уровнях и отсутствии мониторинга таких практик. Внесенные с 1 июля 2021 г. изменения позволяют рассчитывать на введение таких механизмов во всех субъектах РФ и муниципальных образованиях.

Как правило, такие механизмы вводятся нормативными актами высших исполнительных органов государственной власти субъектов $Р \Phi^{10}$ и только в отдельных субъектах РФ - региональными законами ${ }^{11}$. Закон № 184-Ф3 и Закон об обязательных требованиях не определяют форму нормативного акта, утверждающего порядок установления и оценки применения обязательных требований. По нашему мнению, это должен быть исключительно закон субъекта РФ. Этот вывод следует из того, что обязательные требования могут устанавливаться законами субъектов РФ и актами высшего должностного лица субъекта РФ. Акт высшего исполнительного органа государственной власти субъекта РФ не может регулировать порядок установления и оценки применения обязательных требований, устанавливаемых законами субъектов РФ и актами высшего должностного лица субъекта РФ.

В результате такого подхода в отдельных регионах из предмета правового регулирования порядков уста-

Собрание законодательства Российской Федерации. 1999. № 42. Ст. 5005.

8 Собрание законодательства Российской Федерации. 2003. № 40. Ст. 3822.

9 Федеральный закон от 11 июня 2021 г. № 170-Ф3 // Собрание законодательства Российской Федерации. 2021. № 24. Ч. І. Ст. 4188.

10 Например, приняты: Советом министров Республики Крым (в январе 2021 г.), администрацией Владимирской области (в декабре 2020 г.), администрацией Волгоградской области (в декабре 2020 г.), Правительством Воронежской области (в июле 2021 г.), Правительством Ивановской области (в феврале 2021 г.), Правительством Кировской области (в июле 2021 г.), Правительством Магаданской области (в апреле 2021 г.), Правительством Пензенской области (в июне 2021 г.), администрацией Тамбовской области (в январе 2021 г.), Правительством Тюменской области (в феврале 2021 г.), Правительством Ярославской области (в декабре 2020 г.), Правительством Ямало-Ненецкого автономного округа (в сентябре 2020 г.).

11 Например, законы Республики Марий Эл (декабрь 2020 г.), Удмуртской Республики (июль 2021 г.), Краснодарского края (июль 2021 г.), Архангельской (ноябрь 2020 г.), Брянской (январь 2021 г.), Самарской (июль 2021 г.) областей и Еврейской автономной области (апрель 2021 г.). 
новления и оценки применения обязательных требований исключаются обязательные требования, устанавливаемые законами субъектов РФ. Например, в Воронежской области такие правила распространены только на указы губернатора Воронежской области и постановления правительства Воронежской области, устанавливающие обязательные требования, а в Магаданской области - на нормативные акты правительства и органов исполнительной власти Магаданской области.

Обоснованный подход встречаем в законах субъектов РФ, которые дифференцируют установление обязательных требований. Например, согласно закону Еврейской автономной области обязательные требования устанавливаются законами области; в случаях и пределах, которые установлены федеральными конституционными и федеральными законами, нормативными актами Президента РФ и Правительства РФ, уставом и законами области, обязательные требования устанавливаются нормативными актами правительства области и (или) органов исполнительной власти области. Такой подход согласуется с ч. 2 и 3 ст. 2 Закона об обязательных требованиях применительно к обязательным требованиям, установленным федеральными законами, указами Президента РФ, нормативными актами Правительства РФ, федеральных органов исполнительной власти. Учитывая, что обязательные требования содержат ограничения прав (ч. 3 ст. 55 Конституции РФ, п. 2 ст. 1 Гражданского кодекса РФ), вопрос пределов их регулирования на региональном (муниципальном) уровне, а тем более подзаконными актами исполнительных органов является крайне актуальным.

Проблема таких пределов регулирования актуальна, так как часто федеральные законы, допуская введение тех или иных обязательных требований на региональном уровне, не конкретизируют форму нормативного акта, их устанавливающего. В качестве показательного примера можно привести право установления субъектами РФ дополнительных ограничений времени, мест и условий розничной продажи алкогольной продукции, в том числе полный запрет на нее: п. 9 ст. 16 Федерального закона от 22 ноября 1995 г. № 171-Ф3 «О государственном регулировании производства и оборота этилового спирта, алкогольной и спиртосодержащей продукции и об ограничении потребления (распития) алкогольной продукции» (далее - Закон № 171-ФЗ). Судебная практика противоречива в оценке данной нормы федерального закона. Суды общей юрисдикции признают такие акты высших исполнительных органов государственной власти субъектов $Р \Phi^{12}$ не противоречащими федеральному законодательству, указывая, что федеральный законодатель предоставил полномочия в сфере регулирования потребления алкогольной продукции на уровне субъекта РФ не только законодательным органам, но и исполнительным органам государственной власти, включив в законодательство в данной области, наряду с законами, иные нормативные акты субъектов РФ и не выделив законодательные органы субъектов РФ как ор-

12 Определение Верховного Суда РФ от 12 февраля 2014 г. № 5-АПГ13-60, от 18 июня 2014 г. № 59-АПГ14-6, от 28 мая 2014 г. № 31-АПГ14-2, от 11 октября 2017 г. № 47-АПГ17-5, от 1 ноября 2017 г. № 44-АПГ17-18. ганы, к исключительной компетенции которых относится установление дополнительных ограничений (при условии такого делегирования полномочий законом субъекта РФ). С другой стороны, вывод об установлении таких ограничений только законами субъектов РФ сделан Высшим Арбитражным Судом РФ (применительно к п. 2 ст. 1 ГК РФ соответствующие акты могут приниматься только законодательными органами субъектов РФ, поскольку ими вводятся ограничения гражданских прав в сфере экономического оборота) $)^{13}$. Данная позиция сохраняет свою силу до принятия соответствующих решений Пленумом Верховного Суда РФ. Более точным является п. 4.1 ст. 16 Закона № 171-Ф3, который предусматривает возможность только законами субъектов РФ вводить дополнительные ограничения розничной продажи алкогольной продукции при оказании услуг общественного питания в объектах общественного питания, расположенных в многоквартирных домах и (или) на прилегающих к ним территориях (в части увеличения размера площади зала обслуживания посетителей), в том числе полный запрет на нее. Учитывая принцип законности при установлении обязательных требований, применение правил «регулярной гильотины» призвано устранять такой дисбаланс в правовом регулировании обязательных требований.

Принципиальность регулирования порядков установления и оценки применения обязательных требований законами субъектов РФ связана также с тем, что они вводят правила вступления в силу и действия во времени нормативных актов, устанавливающих обязательные требования. Такое регулирование изначально имеет законодательную природу. Сроки вступления в силу и действия нормативных актов субъектов РФ определены конституциями (уставами) и законами субъектов РФ.

Аналогичная ситуация складывается на муниципальном уровне. Лишь немногие муниципальные образования ввели рассматриваемые механизмы, при этом в основном постановлениями местных администраций ${ }^{14}$ и очень редко - решениями представительных органов муниципальных образований (далее - представительный орган) ${ }^{15}$. По уже указанным причинам регулирование порядка установления и оценки применения обязательных требований на муниципальном уровне также должно составлять исключительную компетенцию представительного органа (ч. 10 ст. 35 Закона № 131Ф3). Регулирование данных вопросов местными администрациями приводит также к тому, что обязательные требования, вводимые решениями представительных органов, исключаются из их предмета регулирования, в то время как многие обязательные требования могут

13 П. 12 постановления Пленума Высшего Арбитражного Суда РФ от 11 июля 2014 г. № 47 // Вестник экономического правосудия РФ. 2014. № 9.

14 Например, приняты администрацией Волгограда (в мае 2021 г.), мэрией Магадана (в июне 2021 г.), администрацией Саратова (в апреле 2021 г.), администрацией ЗАТО Северск Томской области, администрацией Тюмени (в ноябре 2020 г.), администрацией Нижневартовска (в июне 2021 г.) и Нефтеюганска (в мае 2021 г.) Ханты-Мансийского автономного округа, администрацией Нальчика (июль 2021 г.) и т. д.

15 Например, решения Ивановской городской Думы (апрель 2021 г.), Архангельской городской Думы (май 2021 г.). 
вводиться только актами представительных органов с соблюдением установленной процедуры их принятия (проведение общественных слушаний или публичных слушаний, оценка регулирующего воздействия (далее ОРВ)). Так, по одному из дел о признании недействующим порядка согласования и оценки внешнего вида (архитектурно-художественного решения) нестационарных торговых объектов суд указал, что к исключительной компетенции представительного органа отнесено утверждение правил благоустройства, включающего требования к внешнему виду фасадов и ограждающих конструкций зданий, строений, сооружений ${ }^{16}$.

Для порядков установления и оценки применения обязательных требований на региональном и муниципальном уровнях обязательным является учет принципов установления и оценки применения обязательных требований, установленных ст. 4-9 Закона об обязательных требованиях. Иные положения данного закона не являются для субъектов РФ и муниципальных образований обязательными, включая положения о действии обязательных требований (ст. 3), об условиях установления обязательных требований (ст. 10), об оценке проектов нормативных актов, устанавливающих обязательные требования (ст. 11), об оценке применения обязательных требований (ст. 12), об официальных разъяснениях обязательных требований (ст. 14). Этим концепция принятого Закона об обязательных требованиях отличается от проекта данного закона, внесенного в Государственную Думу (далее - законопроект № 851072-7 ${ }^{17}$ ), положения которого распространялись как на федеральные, так и на региональные и муниципальные нормативные акты.

Такой подход, с одной стороны, позволяет обеспечить гибкость правового регулирования при установлении и оценке применения обязательных требований на региональном и муниципальном уровнях; субъекты РФ и муниципальные образования смогут определить, какие законоположения, касающиеся установления и оценки применения обязательных требований, предусмотренные Законом об обязательных требованиях, применимы на региональном и муниципальном уровнях и в каком объеме. С другой стороны, такое регулирование создает условия для дифференциации правового регулирования. В частности, такая дифференциация может быть продемонстрирована на примере применения норм Закона об обязательных требованиях, касающихся сроков вступления в силу нормативных актов, устанавливающих обязательные требования, и сроков их действия. Закон об обязательных требованиях предусматривает, что положения нормативных актов, устанавливающих обязательные требования, должны вступать в силу либо с 1 марта, либо с 1 сентября соответствующего года, но не ранее чем по истечении 90 дней после дня официального опубликования; исключения из данного требования могут быть установлены федеральным законом, указом Президента РФ или международным

\footnotetext{
16 Определение Верховного суда Чувашской Республики от 15 мая 2019 г. № 33а-2070/2019.

17 Проект федерального закона № 851072-7 «Об обязательных требованиях в Российской Федерации». URL: https://sozd.duma.gov. ru/bill/851072-7 (дата обращения: 10.09.2021).
}

договором РФ, предусматривающими установление обязательных требований (ч. 1 ст. 3). В региональных и муниципальных практиках встречаются следующие варианты правового регулирования: а) воспроизведение данного требования с исключениями, как это предусматривает федеральная норма ${ }^{18}$; б) воспроизведение данного требования без каких-либо исключений ${ }^{19}$; в) воспроизведение данного требования с исключениями, которые устанавливаются разным кругом актом: федеральным законом или международным договором РФ (без указания на указы Президента РФ) ${ }^{20}$; федеральным законодательством ${ }^{21}$, федеральным законом ${ }^{22}$; федеральным законом и (или) законом субъекта РФ ${ }^{23} ;$ г) не устанавливаются такие требования ${ }^{24}$.

Другое положение Закона об обязательных требованиях касается срока действия нормативного акта, содержащего обязательные требования; он не может превышать шесть лет со дня его вступления в силу, за исключением случаев, установленных федеральным законом или принятым в соответствии с ним нормативным актом Правительства РФ (ч. 4 ст. 3). В региональных и муниципальных практиках встречаются следующие варианты правового регулирования: а) воспроизведение данного требования с исключениями, как это предусматривает федеральная норма ${ }^{25}$; б) воспроизведение данного требования без исключений ${ }^{26}$; в) воспроизведение данного требования с исключениями, которые устанавливаются разным кругом актов: федеральным законом или принятым в соответствии с ним нормативным правовым актом субъекта Р $\Phi^{27}$; федеральным законом, законом субъекта РФ или принятым в соответствии с ним нормативным правовым актом субъекта РФ ${ }^{28}$; законами субъекта РФ ${ }^{29}$; законами субъекта РФ или принятыми в соответствии с ними нормативными правовыми актами высшего исполнительного органа государственной власти субъекта РФ $\Phi^{30}$; законом субъекта РФ или принятым в соответствии с ним нормативным правовым актом субъекта РФ 31 ; законом субъекта РФ или принятым в соответствии с ним нормативным правовым актом выс-

\footnotetext{
18 Например, Краснодарский край.

19 Например, Чеченская Республика, Магаданская, Пензенская и Тамбовская области.

20 Например, Республики Марий Эл, Крым и Северная Осетия Алания, Брянская, Владимирская, Волгоградская, Ивановская и Кировская области, Еврейская автономная область, ЯмалоНенецкий автономный округ, города Волгоград, Иваново, Саратов.

21 Например, Московская область.

22 Например, Тюменская область.

23 Например, Удмуртская Республика.

24 Например, Архангельская, Воронежская и Ярославская области.

Например, Владимирская область.

26 Например, Республики Крым и Северная Осетия-Алания, Чеченская Республика, Волгоградская, Воронежская, Ивановская, Магаданская, Пензенская, Тамбовская и Ярославская области.

27 Например, Брянская область, Еврейская автономная область.

28 Например, Удмуртская Республика.

29 Например, Ямало-Ненецкий автономный округ.

30 Например, Республика Марий Эл, Московская и Тюменская области.

31 Например, Кировская область.
} 
шего должностного лица субъекта $Р \Phi^{32} ;$ г) не устанавливаются такие требования ${ }^{33}$.

Приведенные примеры дифференциации правового регулирования трудно объяснимы и являются результатом отсутствия централизованного регулирования или единого методологического обеспечения. В теории права подчеркивается, что главным при решении вопроса о том, какой вид правового регулирования выбрать, должен быть критерий значимости регулируемых вопросов [1]. Порядок установления и оценки применения обязательных требований содержит совокупность материально-правовых и процессуально-правовых правил. В целях единства правового регулирования материально-правовые вопросы должны носить централизованный и унифицированный характер, что создает условия для их единообразного введения. В частности, такой подход применяется при проведении антикоррупционной экспертизы. С 13 марта 2010 г. действует единая методика проведения антикоррупционной экспертизы нормативных актов и их проектов (постановление Правительства РФ от 26 февраля 2010 г. № 96), что влечет отсутствие основания для ее утверждения на региональном и муниципальном уровнях. Первая такая методика, утвержденная постановлением Правительства РФ от 5 марта 2009 г. № 196, была разработана в целях организации деятельности федеральных органов исполнительной власти. Этот подход привел к тому, что в субъектах РФ и муниципальных образованиях утверждались методики, содержащие различный набор коррупциогенных факторов. Процессуально-правовые правила могут носить децентрализованный и дифференцированный характер, учитывающий особенности публичного управления того или иного уровня.

Рассматриваемая ситуация в части обязательного распространения на региональный и муниципальный уровень тех или иных требований, предусмотренных федеральным законом, может быть соотнесена с регулированием ОРВ. К примеру, Законы № 184-Ф3 и № 131Ф3 определяют круг нормативных актов, в отношении которых не проводится ОРВ. Данные требования, носящие императивный характер, означают, что ни субъекты РФ, ни муниципальные образования не могут изменить данный перечень актов. Данный подход применяется в судебной практике. По одному из дел суд указал несостоятельным довод о праве субъекта РФ самостоятельно определять основания, по которым не проводится процедура ОРВ проектов нормативных актов края, поправок к проектам законов края ${ }^{34}$.

Помимо императивных норм, Закон № 184-ФЗ содержит еще нормы «мягкого права», предусматривающие методическое обеспечение деятельности по проведению ОРВ проектов нормативных актов субъектов РФ, оценки применения обязательных требований, устанавливаемых нормативными актами субъектов РФ, экспертизы, в том числе разработка методических рекомендаций по внедрению порядка проведения ОРВ и порядка проведения процедуры оценки применения обязательных требований в субъектах РФ (далее - методические

\footnotetext{
32 Например, Краснодарский край.

33 Например, Архангельская область.

34 Определение Верховного Суда РФ от 6 декабря 2017 г. № 58-АПГ17-9
}

рекомендации) (п. 7 ст. 26.3.3). Такое методическое обеспечение осуществляется уполномоченным федеральным органом исполнительной власти - Минэкономразвития России. Утвержденные сейчас методические рекомендации ${ }^{35}$ должны быть скорректированы с учетом п. 7 ст. 26.3.3 Закона № 184-ФЗ.

Указанные рекомендации носят ориентирующий характер и направлены на унификацию процедур ОРВ на региональном уровне. В судебной практике встречаются различные подходы к оценке юридической силы рекомендаций. Так, судом признан недействующим в части региональный порядок проведения ОРВ, предусматривающий, что проведение ОРВ зависит от усмотрения разработчика проекта акта и фактически им подменяется $^{36}$. А.А. Ефремов отмечает, что в данном судебном решении рекомендации рассматриваются как императивный нормативный акт [5, с. 30]. В другом судебном решении суд указал, что методические рекомендации признакам нормативного акта не отвечают, Минюстом России не зарегистрированы и официально не опубликованы, поэтому не могут быть оценены в качестве нормативного акта, имеющего бо́льшую юридическую силу, несоответствие которому может привести к признанию оспариваемых правил проведения ОРВ недействующими $^{37}$. Суды согласились с примененным подходом к проведению ОРВ на региональном уровне, который предусматривал, что публичные консультации при осуществлении ОРВ проекта акта, имеющего низкую степень регулирующего воздействия, проводятся по усмотрению разработчика проекта с обоснованием своей позиции в случае нецелесообразности проведения консультаций. Первоначально по другом делу Верховный Суд РФ отказал в признании недействующим постановления правительства области по мотиву непроведения публичных консультаций на основе такой нормы (оспаривался порядок определения юридических лиц, предпринимателей, участников договора простого товарищества, которым свидетельства об осуществлении перевозок по межмуниципальному маршруту регулярных перевозок и карты маршрута выдаются без проведения открытого конкурса) $)^{38}$.

Указанные примеры судебной практики свидетельствует о том, что методические рекомендации служат примером норм «мягкого права», так как окончательное решение о внедрении конкретных процедур принимает субъект РФ; применение таких норм позволяет создавать гибкое правовое регулирование, отличное от федерального регулирования. Применительно к указанному примеру практики п. 4.5 методических рекомендаций содержит рекомендацию закрепить срок

\footnotetext{
5 Приказ Минэкономразвития России от 26 марта 2014 г. № 159 «Об утверждении Методических рекомендаций по организации и проведению процедуры оценки регулирующего воздействия проектов нормативных правовых актов субъектов Российской Федерации и экспертизы нормативных правовых актов субъектов Российской Федерации».

36 Определение Верховного Суда РФ от 17 сентября 2014 г. № 44АПГ14-13.

37 Определение Верховного Суда РФ от 30 января 2019 г. № 83АПГ18-19.

38 Определение Верховного Суда РФ от 12 декабря 2018 г. № 83АПГ18-15.
} 
проведения публичных консультаций с учетом степени регулирующего воздействия проекта нормативного акта не менее 20, 10 и 5 рабочих дней для высокой, средней и низкой степеней регулирующего воздействия соответственно.

Дальнейшее развитие Закона об обязательных требованиях может идти как по пути расширения перечня императивных норм, обязательных для регионального и муниципального уровней, так и внедрения норм «мягкого права». В рамках первого подхода положения Закона об обязательных требованиях в части условий установления обязательных требований (ст. 10) могут быть применены как обязательные для регионального и муниципального уровней. Анализ региональных и муниципальных практик свидетельствует о применении данных условий.

Закон об обязательных требованиях, а также Законы № 184-Ф3 и 131-Ф3 не содержат норм о методическом обеспечении внедрения порядка установления обязательных требований на региональном и муниципальном уровнях. Такие нормы могли бы быть включены в указанные федеральные законы, в развитие которых утверждены методические рекомендации по внедрению порядка установления и оценки применения обязательных требований на региональном и муниципальном уровнях.

Единообразное применение принципов и условий установления обязательных требований, предусмотренных федеральным законом, призвано качественно улучшить нормативное регулирование обязательных требований. В этой связи выразим несогласие с мнением М.А. Дмитриева, что обязательность проведения ОРВ проектов региональных нормативных актов, предусмотренных п. 1 ст. 26.3.3 Закона № 184-Ф3, не подпадает под характеристику общих принципов организации системы органов государственной власти субъектов РФ (как предмета правового регулирования Закона № 184Ф3) [4]. Общие принципы правотворческой деятельности органов публичной власти как на региональном, так и муниципальном уровне традиционно относятся к общим принципам организации органов государственной власти субъектов РФ и общим принципам организации местного самоуправления. Установление в Российской Федерации общих принципов правотворческой деятельности в полной мере охватывает ее полномочия по предметам совместного ведения Российской Федерации и ее субъектов.

В свою очередь, несоблюдение рассматриваемых принципов и условий должно влечь признание региональных или муниципальных актов недействующими. Применение таких принципов и условий должно составить не только деятельность правотворческих органов, но и органов, осуществляющих экспертизу региональных (муниципальных) нормативных актов и надзор за их законностью, а также суда. Оценка соблюдения принципов установления и оценки применения обязательных требований (в том числе законность, обоснованность, правовая определенность и системность, исполнимость), условий их установления применительно к нормативным актам субъектов РФ должна осуществляться территориальными органами Минюста России в ходе их правовой экспертизы и органами прокуратуры при надзоре за их законностью. Соответственно, в данной части могут быть конкретизированы Методические рекомендации по проведению правовой экспертизы нормативных правовых актов субъектов РФ, утвержденные Минюстом России ${ }^{39}$, и приказ Генпрокуратуры России $^{40}$. Применительно к муниципальным нормативным актам такая оценка должна осуществляться в ходе правовой экспертизы, проводимой органами государственной власти субъекта РФ, уполномоченными на ведение регистров таких актов.

Аналогичным образом должно быть скорректировано постановление Пленума Верховного Суда РФ от 25 декабря 2018 г. № 50 «О практике рассмотрения судами дел об оспаривании нормативных правовых актов и актов, содержащих разъяснения законодательства и обладающих нормативными свойствами» ${ }^{41}$. В юридической литературе уже вносились предложения о необходимости расширения сферы судебного контроля, совершенствования процессуального законодательства и положений пленумов Верховного Суда РФ по рассмотрению дел об оспаривании нормативных актов в сфере предпринимательской и инвестиционной деятельности [5, с. 33].

\section{2. Правовые средства оценки обязательных требований}

Внесенные в развитие Закона об обязательных требованиях изменения в Закон № 184-ФЗ (подп. «а» п. 1, п. 2, 3, 4 ст. 26.3.3) и Закон № 131-Ф3 предусматривают проведение ОРВ в отношении проектов региональных и муниципальных нормативных актов, устанавливающих новые, изменяющих или отменяющих ранее предусмотренные ими обязательные требования, связанные с осуществлением предпринимательской и иной экономической деятельности, оценка соблюдения которых осуществляется в рамках государственного контроля (надзора), привлечения к административной ответственности, предоставления лицензий и иных разрешений, аккредитации, оценки соответствия продукции, иных форм оценок и экспертиз. В отношении указанных региональных и муниципальных нормативных актов проводится также оценка фактического воздействия указанных нормативных актов (п. 5 ст. 26.3.3 Закона № 184-Ф3).

Законодательно сохранен дифференцированный подход к решению вопроса об обязательности проведения ОРВ на муниципальном уровне (ч. 6.1 ст. 8, ч. 3-6 ст. 46 Закона № 131-Ф3). Такая обязанность действует в отношении городских округов, являющихся административными центрами субъектов РФ, а также иных городских округов, муниципальных округов и муниципальных районов, включенных в соответствующий перечень законом субъекта РФ (ч. 3 и 6 ст. 46 Закона

\footnotetext{
39 Приказ Минюста России от 31 мая 2012 г. № 87 «Об утверждении Методических рекомендаций по проведению правовой экспертизы нормативных правовых актов субъектов Российской Федерации» // Бюллетень Минюста РФ. 2013. № 1.

40 Приказ Генпрокуратуры России от 2 октября 2007 г. № 155 «Об организации прокурорского надзора за законностью нормативных правовых актов органов государственной власти субъектов Российской Федерации и местного самоуправления».

41 Бюллетень Верховного Суда РФ. 2019. № 2.
} 
№ 131-Ф3). Критериями формирования таких перечней должны быть объективные особенности осуществления местного самоуправления, включая степень концентрации возложенных на муниципальные образования государственных полномочий. По нашему убеждению, в связи с введением порядка установления и оценки применения обязательных требований данный подход должен быть изменен, и процедура ОРВ должна применяться на всех уровнях муниципального управления.

Такой вывод подтверждает и судебная практика, которая свидетельствует о значительном числе нарушений порядка проведения ОРВ на муниципальном уровне. Например, нарушение порядка проведения ОРВ повлекло признание недействующими: порядка согласования и оценки внешнего вида (архитектурно-художественного решения) нестационарных торговых объектов ${ }^{42}$; порядка размещения нестационарных торговых объектов (в части норм о прекращении действия договора на размещение таких объектов в одностороннем порядке в случае передачи или уступки прав по договору третьим лицам без переоформления разрешительной документации на установку либо передачи нестационарного торгового объекта третьим лицам на условиях аренды или безвозмездного пользования без переоформления разрешительных документов на установку $)^{43}$; изменения в порядок организации и проведения аукциона на право размещения нестационарных торговых объектов (уточнены правила отбора хозяйствующих субъектов $)^{44}$ или порядка рассмотрения заявлений о включении, исключении нестационарных торговых объектов в схему размещения нестационарных торговых объектов ${ }^{45}$; административного регламента по предоставлению муниципальных услуг по выдаче разрешения на право организации ярмарки ${ }^{46}$ и по выдаче, переоформлению и продлению срока действия разрешения на право организации розничного рынка ${ }^{47}$; порядка выявления, выноса, хранения и возврата законным владельцам объектов движимого имущества, незаконно размещенных на территории муниципального образования ${ }^{48}$; реестра маршрутов регулярных перевозок муниципальной маршрутной сети города, который изложен в новой редакции ${ }^{49}$, или документа планирования регулярных перевозок ${ }^{50}$; изменения в схему границ прилегающих территорий организаций и объектов, на которых не допускается розничная продажа алкоголь-

42 Определение Верховного суда Чувашской Республики от 15 мая 2019 г. № 33а-2070/2019.

43 Определение Верховного Суда РФ от 29 июня 2016 г. № 14-АПГ16-8.

44 Определение Верховного Суда Чувашской Республики от 27 мая 2019 г. № 33а-3485/2018.

45 Определение Саратовского областного суда от 16 января 2020 г. № $33 \mathrm{a}-34 / 2020$.

46 Определение Нижегородского областного суда от 2 декабря 2015 г. № 33a-12650/2015.

47 Определение Нижегородского областного суда от 11 мая 2016 г. № 33a-4869/2016.

48 Определение Свердловского областного суда от 6 июня 2019 г. № 33a-8983/2019.

49 Решение Советского районного суда города Орла от 23 сентября 2020 г. № 2a-1457/2020.

50 Решение Советского районного суда города Орла от 18 июня 2019 г. № 2a-856/2019. ной продукции (утверждена схема к муниципальной образовательной организации) ${ }^{51}$; текстовая и графическая части схемы размещения нестационарных торговых объектов ${ }^{52}$; порядка регулирования вопросов арендной платы за землю ${ }^{53}$.

Признавая такие акты недействующими, суд, как правило, указывал, что целью проведения ОРВ служит ознакомление субъектов регулируемых отношений с проектом муниципального нормативного акта в целях выявления положений, вводящих избыточные для них обязанности, запреты и ограничения. Примеры судебной практики свидетельствуют о важности соблюдения требований о проведении ОРВ на муниципальном уровне, включая учет методических рекомендаций по внедрению порядка проведения ОРВ и порядка проведения процедуры оценки применения обязательных требований в муниципальных образованиях ${ }^{54}$. Закон № 131-Ф3, в отличие от Закона № 184-Ф3, не содержит положений об утверждении таких рекомендаций, что предлагается скорректировать.

Нормативные акты субъектов РФ, содержащие обязательные требования и подлежащие оценке фактического воздействия, не подлежат экспертизе (п. 6 статьи 26.3.3 Закона № 184-Ф3). Для муниципальных актов, содержащих обязательные требования и подлежащих оценке фактического воздействия, ч. 6-7 ст. 7 Закона № 131-Ф3 такого исключения не содержат. Данными законами предусмотрено проведение в целях выявления положений, необоснованно затрудняющих осуществление предпринимательской и инвестиционной деятельности, экспертизы: нормативных актов субъектов РФ, устанавливающих новые, изменяющие или отменяющие ранее предусмотренные ими обязанности и запреты для субъектов предпринимательской и инвестиционной деятельности; устанавливающие, изменяющие или отменяющие ответственность за нарушение нормативных актов субъектов РФ, затрагивающих вопросы осуществления предпринимательской и иной экономической деятельности (п. 6 статьи 26.3.3 Закона № 184-Ф3); муниципальных актов, затрагивающих вопросы осуществления предпринимательской и инвестиционной деятельности (ч. 6 и 7 ст. 7 Закона № 131-Ф3).

\section{3. Реализация «регуляторной гильотины»}

Положения ст. 15 Закона об обязательных требованиях, посвященной обеспечению реализации положений Закона об обязательных требованиях («регуляторная гильотина»), не распространяются на региональный и муниципальный уровень.

Изначально законопроектом № 851072-7 предполагалось, что субъектами РФ до 1 января 2022 г. должна

\footnotetext{
51 Определение Верховного суда Республики Карелия от 22 июня 2020 г. № 2a-978/2020.

52 Определение Омского областного суда от 5 апреля 2017 г. № 33а$2129 / 2017$.

53 Решение Челябинского областного суда от 27 февраля 2018 г. № 3а$44 / 2018$.

54 Методические рекомендации по организации и проведению процедуры регулирующего воздействия проектов муниципальных нормативных правовых актов (письмо Минэкономразвития России от 12 декабря 2014 г. № 31260-ОФ/Д26и).
} 
быть обеспечена отмена нормативных актов субъектов РФ, содержащих обязательные требования, оценка соблюдения которых проводится в рамках осуществления государственного контроля (надзора), вступивших в силу до 1 января 2021 г.; независимо от того, отменены ли указанные нормативные акты, несоблюдение содержащихся в них требований с 1 января 2022 г. не может являться основанием для привлечения к административной ответственности. Муниципальные акты, содержащие обязательные требования, оценка соблюдения которых проводится в рамках осуществления муниципального контроля и предоставления муниципальных услуг, вступившие в силу до 1 января 2021 г., должны были быть признаны утратившими силу до 1 января 2023 г; независимо от того, отменены ли такие муниципальные нормативные акты, несоблюдение содержащихся в них требований с 1 января 2023 г. не может являться основанием для привлечения к административной ответственности.

Тем самым необходимость «регуляторной гильотины» на региональном и муниципальном уровне, сроки ее проведения самостоятельно определяют субъекты РФ и муниципальные образования. Такой подход является обоснованным, учитывая особенности предмета региональных и муниципальных актов. Например, на муниципальном уровне это правила благоустройства, генеральные планы, правила землепользования и застройки, акты о схемах размещения рекламных конструкций, схемах размещения нестационарных торговых объектов, границах прилегающих территорий в целях благоустройства или ограничений оборота алкогольной продукции и т. д. Одномоментная отмена таких актов, очевидно, неэффективна и не соответствует требованиям стабильности правового регулирования. Такой аспект справедливо отмечается в исследовании В.В. Летуновского и А.А. Агеева, которые указывают, что основной риск при уточнении контрольно-надзорной функциональности это возможность проявления «вируса правоотрицания»; в ходе любых трансформаций возникают соблазны быстрого устранения очевидных недостатков, за которыми могут скрываться элементы праворазрушения [6].

Принципиально важным моментом является оценка региональных и муниципальных актов на предмет соответствия принципам, предусмотренным Законом об обязательных требованиях, и наличия в них положений, предусмотренных ч. 1 ст. 10 данного закона. По результатам такой оценки органы государственной власти субъектов РФ и органы местного самоуправления должны вносить изменения в нормативные акты или признавать данные акты утратившими силу.

Например, законы Архангельской области и Еврейской автономной области предусматривают разработку планов мероприятий («дорожных карт») по оценке применения содержащихся в нормативных актах, принятых до вступления в силу указанных законов, обязательных требований. План мероприятий («дорожная карта») формируется на основе предложений контрольных (надзорных) органов государственной власти области, уполномоченного по защите прав предпринимателей, субъектов предпринимательской и иной экономической деятельности области, общественных объединений в сфере предпринимательской и иной экономической деятельности. Такие практики должны применяться во всех субъектах РФ и муниципальных образованиях.

\section{Выводы}

1. Создание правил установления и оценки применения обязательных требований должно быть завершено во всех субъектах РФ и в муниципальных образованиях. На федеральном уровне необходимо определить, какой федеральный орган исполнительной власти координирует такую работу на региональном и муниципальном уроне и осуществляет ее методическое обеспечение (например, Департамент регуляторной политики и оценки регулирующего воздействия Минэкономразвития России и Департамент регуляторной политики и развития законодательства Минюста России).

2. Правила установления и оценки применения обязательных требований на региональном и муниципальном уровнях должны вводиться соответственно законами субъектов РФ и решениями представительных органов, в связи с чем должны быть скорректированы ч. 5 ст. 2 Закона об обязательных требованиях, а также п. 5 ст. 26.3-3 Закона № 184-Ф3 и ч. 6.1 ст. 7 Закона № 131-Ф3.

3. Не только принципы установления и оценки применения обязательных требований, установленные ст. 4-9 Закона об обязательных требованиях, но и более широкий круг требований Закона об обязательных требованиях должен быть обязательным для субъектов РФ и муниципальных образований. Например, это должно касаться условий установления обязательных требований (ч. 1 ст. 10). Предлагается также внести изменения в Законы № 184-Ф3 и 131-Ф3 в части установления для субъектов РФ и муниципальных образований методических рекомендаций по внедрению порядка установления и оценки применения обязательных требований.

4. Процедура оценки регулирующего воздействия должна применяться на всех уровнях муниципального управления, в связи с чем предлагается скорректировать ч. 3 и 6 ст. 46 Закона № 131-ФЗ. Предлагается также предусмотреть в Законе № 131-ФЗ принятие методических рекомендаций по внедрению порядка проведения ОРВ и порядка проведения процедуры оценки применения обязательных требований в муниципальных образованиях (по аналогии с п. 7 ст. 26.3.3 Закона № 184-Ф3).

5. Проверку соблюдения правил установления и оценки применения обязательных требований на региональном и муниципальном уровнях должны проводить органы прокуратуры, юстиции и уполномоченные органы субъектов РФ по ведению регистра муниципальных нормативных актов в рамках их полномочий. Предлагается также скорректировать постановление Пленума Верховного Суда РФ от 25 декабря 2018 г. № 50 «О практике рассмотрения судами дел об оспаривании нормативных правовых актов и актов, содержащих разъяснения законодательства и обладающих нормативными свойствами».

6. Принципиально важно обеспечить проведение оценки региональных и муниципальных актов на предмет соответствия принципам и условиям установления обязательных требований, установленным Законом об обязательных требованиях. Это позволит запустить механизм «регуляторной гильотины» на региональном и муниципальном уровнях. 


\section{Литература}

1. Морозова Л. А. Теория государства и права в вопросах и ответах // М. : Эксмо, 2019. 340 с.

2. Горбачев С.А., Зудов Ю.В. Совершенствование системы оценки нормативных правовых актов Российской Федерации // Мониторинг правоприменения. 2019. № 1. С. 30-38.

3. Дидикин А.Б. Обязательные требования и правовые средства их оценки в механизме регуляторной политики // Мониторинг правоприменения. 2021. № 1. С. 4-9.

4. Дмитриев М.А. Обязательность оценки регулирующего воздействия как общий принцип организации системы органов государственной власти субъектов Российской Федерации // Российский юридический журнал. 2020. № 2. С. 118-129.

5. Ефремов А.А. Формирование судебной практики по вопросам оценки регулирующего воздействия // Арбитражный и гражданский процесс. 2015. № 8. С. 28-33.

6. Летуновский В.В., Агеев А.А. Некоторые проблемы реализации мероприятий «регуляторной гильотины» // Административное право и процесс. 2021. № 1. С. 34-42.

7. Майоров В.И. Модернизация системы контроля и надзора: новая регуляторная политика // Административное право и процесс. 2019 . № 11. C. $34-36$.

8. Пахомов А.В. Об особенностях применения нового законодательства об обязательных требованиях на муниципальном уровне // Муниципальное имущество: экономика, право, управление. 2020. № 4. С. 41-44.

\section{IMPLEMENTATION OF THE “REgULATORY GUILLOTINE" AT THE REgIONAL AND MUNICIPAL LEVEL}

\section{Andreechev 55}

Keywords: control and oversight activities, mandatory requirements, "regulatory guillotine", establishment of mandatory requirements, assessment of application of mandatory requirements, validity of mandatory requirements, assessment of regulatory impact, assessment of actual impact.

\section{Abstract.}

Purpose of the paper: analysing the introduction and implementation of the "regulatory guillotine" mechanisms at the regional and municipal levels considering the importance of improving control and oversight activities and this lawmaking technology.

Methods of study: the study was carried out using the formal legal, comparative legal and system methods.

Results of study: the author showed significant shortcomings in the legal model of the "regulatory guillotine" at the regional and municipal level in the Federal Law "On Mandatory Requirements in the Russian Federation" and other federal laws as well as in the practice of its introduction and application in subjects of the Russian Federation and municipal formations. Proposals for improving the federal laws with a view to reduce the differentiation of regional and municipal legal regulation, its synchronisation and unification with federal regulation of the establishment and assessment of application of mandatory requirements as well as for the methodological support for such work are formulated in the paper.

\section{References}

1. Morozova L. A. Teoriia gosudarstva i prava v voprosakh i otvetakh. M. : Eksmo, 2019. 340 c.

2. Gorbachev S.A., Zudov Iu.V. Sovershenstvovanie sistemy otsenki normativnykh pravovykh aktov Rossiiskoi Federatsii. Monitoring pravoprimeneniia, 2019, No. 1, pp. 30-38.

3. Didikin A.B. Obiazatel'nye trebovaniia i pravovye sredstva ikh otsenki v mekhanizme reguliatornoi politiki. Monitoring pravoprimeneniia, 2021, No. 1, pp. 4-9.

4. Dmitriev M.A. Obiazatel'nost' otsenki reguliruiushchego vozdeistviia kak obshchii printsip organizatsii sistemy organov gosudarstvennoi vlasti sub"ektov Rossiiskoi Federatsii. Rossiiskii iuridicheskii zhurnal, 2020, No. 2, pp. 118-129.

5. Efremov A.A. Formirovanie sudebnoi praktiki po voprosam otsenki reguliruiushchego vozdeistviia. Arbitrazhnyi i grazhdanskii protsess, 2015, No. 8, pp. 28-33.

55 Igor' Andreechev, Deputy Head of Administration - Director of the Legal Department of the Administration of the Governor of Arkhangelsk Oblast and the Government of Arkhangelsk Oblast, Arkhangelsk, Russia. E-mail: andreechev@dvinaland.ru 
6. Letunovskii V.V., Ageev A.A. Nekotorye problemy realizatsii meropriiatii "reguliatornoi gil’otiny". Administrativnoe pravo i protsess, 2021, No. 1, pp. 34-42.

7. Maiorov V.I. Modernizatsiia sistemy kontrolia i nadzora: novaia reguliatornaia politika. Administrativnoe pravo i protsess, 2019, No. 11, pp. 34-36.

8. Pakhomov A.V. Ob osobennostiakh primeneniia novogo zakonodatel'stva ob obiazatel'nykh trebovaniiakh na munitsipal'nom urovne. Munitsipal'noe imushchestvo: ekonomika, pravo, upravlenie, 2020, No. 4, pp. 41-44.

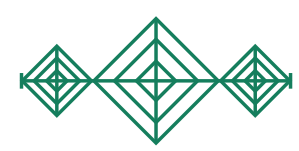




\title{
ИСПОЛНЕНИЕ ОБЯЗАТЕЛЬСТВ ТРЕТЬИМ ЛИЦОМ ПЕРЕД ЕДИНСТВЕННЫМ КРЕДИТОРОМ ПОСЛЕ ВВЕДЕНИЯ ПРОЦЕДУРЫ НАБЛЮДЕНИЯ
}

\author{
Зайцев В. В. ${ }^{1}$, Кравченко А. А. ${ }^{2}$, Бедросов В. Э. $^{3}$
}

Ключевые слова: несостоятельность (банкротство), процедура наблюдения, очередность и пропорциональность удовлетворения требований, единственный кредитор, добросовестность, Верховный Суд Российской Федерации, судебная практика.

\section{Аннотация.}

Цель работы: оценка проблематики исполнения обязательств должника третьим лицом перед единственным кредитором с учетом правовых позиций высших судебных инстанций, общеправовых и частноправовых принципов и выявление концептуальных проблем при применении указанного подхода в делах о несостоятельности (банкротстве) юридических лиц с участием единственного кредитора.

Методы исследования: методологическую основу исследования составили всеобщий диалектический метод познания и основанные на нем общенаучные и частнонаучные методы исследования, формально-логический метод.

Результаты исследования. Основное значение в достижении цели работы имеет анализ правоприменительной практики арбитражных судов в делах о несостоятельности (банкротстве) юридических лиц в части отказа в признании надлежащим исполнения обязательств должника третьими лицами после введения первой процедуры - наблюдения.

В работе рассмотрены основные тенденции применения пункта 28 Обзора о недопустимости погашения задолженности третьими лицами после введения первой процедуры банкротства без учета количества кредиторов в деле о банкротстве. Авторами сформулированы существенные концептуальные недостатки такого применения в делах с участием единственного кредитора, обязательства должника перед которым исполнены третьим лицом в полном объеме.

В первой части работы выявлены общие положения о погашении задолженности третьим лицом при несостоятельности должника - юридического лица и предпосылки формирования правового подхода о недопустимости такого погашения в первой процедуре банкротства.

Во второй части работы определена сущность указанного подхода в судебно-арбитражной практике, затрагивающей исполнение третьим лицом обязательств должника перед единственным кредитором, причины отказа судов в признании такого исполнения надлежащим, а также правовые последствия указанного отказа.

В заключительной части работы авторы уделили особое внимание правовому обоснованию недопустимости отказа в удовлетворении ходатайства о прекращении производства по делу при полном удовлетворении реестровых требований единственного кредитора.

DOI: 10.21681/2226-0692-2021-4-31-39

\section{1. Общие положения о погашении задолженности третьим лицом}

B

сложившейся судебной практике рассмотрения дел о несостоятельности (банкротстве) юридических лиц нередки случаи, при которых третье лицо, не участвующее в таком деле, имеющее или не имеющее каких-либо соглашений с должником, имеет намерение погасить задолженность перед кредиторами.
По общему правилу, если производство по делу о несостоятельности (банкротстве) еще не возбуждено, такое намерение погасить задолженность регулируется общей нормой ст. 313 Гражданского кодекса Российской Федерации (далее - ГК РФ).

\footnotetext{
Зайцев Владимир Васильевич, доктор юридических наук, профессор, профессор кафедры правового обеспечения рыночной экономики Высшей школы правоведения ИГСУ РАНХиГС при Президенте Российской Федерации, г. Москва, Российская Федерация. E-mail: vzaytsev@ranepa.ru (раздел 6 и раздел «Вывод»).

2 Кравченко Александр Александрович, кандидат юридических наук, доцент кафедры правового обеспечения рыночной экономики Высшей школы правоведения ИГСУ РАНХиГС при Президенте Российской Федерации, г. Москва, Российская Федерация. E-mail: aa.kravchenko@igsu.ru (разделы 4-5).

3 Бедросов Владислав Эдуардович, аспирант Высшей школы правоведения ИГСУ РАНХиГС при Президенте Российской Федерации, г. Москва, Российская Федерация. E-mail: ve.bedrosov@gmail.com (разделы 1-3).
} 


\begin{tabular}{|c|c|c|}
\hline $\begin{array}{c}\text { Процедура, применяемая } \\
\text { при несостоятельности } \\
\text { (банкротстве) юридиче- } \\
\text { ского лица }\end{array}$ & $\begin{array}{c}\text { Правовые основания погашения за- } \\
\text { долженности третьим лицом } \\
\text { в соответствии с } \\
\text { Законом о банкротстве }\end{array}$ & $\begin{array}{c}\text { Правовые основания погашения за- } \\
\text { долженности по обязательным плате- } \\
\text { жам третьим лицом в соответствии с } \\
\text { Законом о банкротстве }\end{array}$ \\
\hline Наблюдение & $\mathrm{X}$ & Статья 71.1 Закона о банкротстве \\
\hline Финансовое оздоровление & $\begin{array}{c}\mathrm{X} \\
\text { (согласно ст. 89 Закона о банкротстве } \\
\text { только в отночении лии, предоста- } \\
\text { вивших обеспечение) }\end{array}$ & Статья 85.1 Закона о банкротстве \\
\hline Внешнее управление & Статья 113 Закона о банкротстве & Статья 112.1 Закона о банкротстве \\
\hline Конкурсное производство & Статья 125 Закона о банкротстве & Статья 129.1 Закона о банкротстве \\
\hline Мировое соглаш & \multicolumn{2}{|c|}{$\begin{array}{c}\text { При заключении мирового соглашения соответствующие правовые основания } \\
\text { отсутствуют ввиду отсутствия их необходимости }\end{array}$} \\
\hline
\end{tabular}

* Статья 27 Закона о банкротстве.

Так, в случае наличия соглашения между третьим лицом и должником следует руководствоваться пунктом 1 статьи 313 ГК РФ: «кредитор обязан принять исполнение, предложенное за должника третьим лицом, если исполнение обязательства возложено должником на указанное третье лицо».

Между тем действующее гражданское законодательство также регулирует и случай, при котором вышеуказанное соглашение отсутствует. Так, в соответствии с пунктом 2 статьи 313 ГК РФ: «Если должник не возлагал исполнение обязательства на третье лицо, кредитор обязан принять исполнение, предложенное за должника таким третьим лицом, в следующих случаях: 1) должником допущена просрочка исполнения денежного обязательства; 2) такое третье лицо подвергается опасности утратить свое право на имущество должника вследствие обращения взыскания на это имущество».

Таким образом, по общему правилу кредитор обязан принять исполнение третьего лица по его инициативе только тогда, когда имеет место просроченное денежное обязательство либо кредитор знал или должен был знать об опасности третьего лица утратить права на имущество должника [1].

Неисполнение вышеуказанной обязанности ведет, как указывает Верховный Суд Российской Федерации, к признанию кредитора просрочившим. При этом по денежному обязательству кредитор не обязан проверять наличие каких-либо правовых отношений по соответствующему погашению между должником и третьим лицом ${ }^{4}$.

\section{2. Погашение задолженности третьим лицом при несостоятельности (банкротстве) должника}

Зачастую неисполнение денежного обязательства должника может приводить к инициации процедуры несостоятельности.

4 Постановление Пленума Верховного Суда РФ от 22.11.2016 № 54 «О некоторых вопросах применения общих положений Гражданского кодекса Российской Федерации об обязательствах и их исполнении».
При инициировании банкротства и намерении третьего лица погасить задолженность, тем самым «заняв место» первоначального кредитора, порядок такого погашения становится также предметом регулирования специальных норм Федерального закона от 26.10.2002 № 127-Ф3 «О несостоятельности (банкротстве)» (далее также - Закон о банкротстве).

В зависимости от конкретной процедуры банкротства и вида обязательства порядок погашения требований кредиторов различен (табл. 1). Так, Закон о банкротстве разграничивает обычные денежные обязательства, возникающие в рамках гражданского оборота, и обязательства по уплате обязательных платежей (налоги, сборы, штрафы, пени и т. д., подлежащие уплате в бюджет соответствующего уровня бюджетной системы).

Таким образом, формально в процедуре наблюдения погашение третьим лицом обычной задолженности должника не допускается.

Следует кратко рассмотреть порядок и условия удовлетворения требований кредиторов третьими лицами, установленные статьями 113 и 125 Закона о банкротстве в процедурах внешнего управления и конкурсного производства соответственно.

Удовлетворение требований кредиторов третьими лицами в процедуре внешнего управления. По большому счету, Закон о банкротстве содержит лишь два условия признания такого удовлетворения надлежащим:

1) удовлетворение всего объема требований кредиторов, включенных в реестр, и вместе с ними всех санкций (штрафы, пени, проценты и др.) за неисполнение или ненадлежащее исполнение обязательств (пункт 1 статьи 113);

2) соблюдение установленного статьей 113 Закона о банкротстве порядка.

Удовлетворение требований кредиторов третьими лицами в процедуре конкурсного производства. В соответствии с пунктом 1 статьи 125 Закона о банкротстве третьи лица в любое время до окончания конкурсного производства вправе одновременно удовлетворить все требования кредиторов в соответствии с реестром требований кредиторов или предоставить должнику денежные средства, достаточные для удовлетворения всех требований кредиторов в соответствии с реестром тре- 
бований кредиторов в порядке и на условиях, которые предусмотрены статьей 113 Закона о банкротстве.

Таким образом, процесс удовлетворения требований кредиторов третьими лицами в процедуре конкурсного производства идентичен порядку удовлетворения требований в процедуре внешнего управления.

Специальный порядок погашения задолженности третьим лицом в процедурах конкурсного производства и внешнего управления в сравнении с общим порядком, предусмотренным статьей 313 ГК РФ, отличается более высокой степенью сложности и урегулированности, он подвержен тщательному контролю со стороны арбитражного суда и назначаемых им лиц.

Формальное отсутствие в Законе о банкротстве порядка погашения задолженности третьим лицом в процедуре наблюдения приводит к возникновению дискуссий в доктрине.

Так, Петров Д.А. указывает, что «с одной стороны, представляется неправильным лишение учредителя или третьего лица возможности удовлетворить требования кредиторов в рамках наблюдения или финансового оздоровления. Получается несколько несправедливо, что погашение учредителем или третьим лицом задолженности по обязательным платежам в ходе наблюдения и финансового оздоровления возможно (статьи 71.1, 85.1 Закона о банкротстве), а вот погашение задолженности по гражданско-правовым обязательствам - нет» [2].

Аналогичной позиции придерживается Ватлин Л.А., подчеркивая, что «в подобном подходе законодателя снова проявляется неоправданное наделение уполномоченного органа более привилегированным статусом по сравнению с другими кредиторами. Поскольку удовлетворить требования государства можно на любой стадии процесса, представляется возможным это сделать и в отношении всех иных кредиторов» [1].

Что еще опаснее, формальное отсутствие в Законе о банкротстве порядка погашения задолженности третьим лицом в процедуре наблюдения привело на практике к возникновению правового подхода арбитражных судов, при котором суды отказывают в признании перехода права требования к третьему лицу состоявиимся и сохраняют такое право за первоначальным кредитором в случае, если исполнение обязательства было произведено третьим тицом после введения наблюдения (для целей настоящей статьи в дальнейшем «негативный правовой подход арбитражных судов»).

Такой подход представляется противоречивым (в соотношении с процедурами конкурсного производства и внешнего управления). Как минимум, в ситуации наличия единственного кредитора такой негативный правовой подход арбитражных судов не соотносится с принципами справедливости и разумности.

\section{3. Предпосылки формирования правовой позиции о недопустимости погашения требований кредиторов третьим лицом в процедуре наблюдения}

До декабря 2016 года была широко распространена практика, при которой третьи лица исполняли обязательства за должника после инициирования дела о несо- стоятельности (банкротстве). Такое исполнение зачастую могло иметь своей целью получение прав требования заявителя в деле для осуществления контроля над ходом процедуры банкротства, в том числе для предложения «своей» кандидатуры арбитражного управляющего.

Развитие правоотношений в указанном контексте в коммерческом обороте, безусловно, имело деструктивное влияние.

Как справедливо указывал Верховный Суд Российской Федерации, «исполнение третьим лицом обязательства должника на основании статьи 313 ГК РФ до введения первой процедуры банкротства не может быть признано злоупотреблением правом при отсутствии доказательств того, что поведение третьего лица причинило вред лицам, участвующим в деле о банкротстве» (см. пункт 17 Обзора судебной практики Верховного Суда Российской Федерации № 2 от 26.04.2017).

При наличии доказательств того, что поведение третьего лица причинило вред лицам, участвующим в деле о банкротстве, исполнение третьим лицом может свидетельствовать о принудительном «выкупе» (пункт 2 статьи 313 ГК РФ) прав требования к должнику в целях установления контроля за ходом дела о банкротстве [3].

Вследствие этого наличие признаков недобросовестности в действиях третьего лица, производящего погашение долга за должника, стало основанием для признания перехода прав кредитора к такому лицу несостоявшимся и сохранения права требования за первоначальным кредитором (пункт 21 постановления Пленума Верховного Суда Российской Федерации от 22.11.2016 № 54 «О некоторых вопросах применения общих положений Гражданского кодекса Российской Федерации об обязательствах и их исполнении»).

Аналогичным образом оцениваются и действия, направленные на погашение третьим лицом долга частично до уровня, который не позволяет требовать признания должника банкротом [4].

Таким образом, целью недопущения погашения требований кредиторов третьим лицом в процедуре наблюдения является ограничение злоупотреблений правом со стороны третьих лиц.

\section{4. Негативный правовой подход арбитражных судов}

Указанный выше подход впервые на уровне высшей судебной инстанции был закреплен в пункте 28 Обзора судебной практики по вопросам, связанным с участием уполномоченных органов в делах о банкротстве и применяемых в этих делах процедурах банкротства, утвержденного Президиумом Верховного Суда РФ 20.12.2016.

Пожалуй, наиболее существенными для целей исследования являются три вывода, которые впоследствии стали применяться нижестоящими инстанциями повсеместно в качестве общеобязательной нормы:

1. «После введения первой процедуры по делу о банкротстве третье лиио в индивидуальном порядке вправе погасить только требования уполномоченного органа по обязательным платежам на основании положений статей 71.1, 85.1, 112.1 и 129.1 Закона о банкротстве».

2. «Обязательства по иным требованиям могут быть исполнены третьим тииом тишь в процедурах 
внешнего управления тибо конкурсного производства в соответствии со специальными правилами, установтенными статьями 113 и 125 Закона о банкротстве. Положения подпункта 1 пункта 2 статьи 313 Гражданского кодекса Российской Федерации после введения в отночении должника первой проиедуры банкротства применению не подлежат».

3. «Положения подпункта 1 пункта 2 статьи 313 Гражданского кодекса Российской Федераиии, как допускающие исполнение обязательства перед отдельным кредитором в индивидуальном порядке, не могут быть применены после введения в отношении должника первой проиедуры банкротства».

Ранее Верховный Суд Российской Федерации давал похожие разъяснения, но только в отношении обязательных платежей, в пункте 21 Постановления Пленума Верховного Суда РФ от 22.11.2016 № 54 «О некоторых вопросах применения общих положений Гражданского кодекса Российской Федерации об обязательствах и их исполнении»: «Статьи 71.1, 85.1, 112.1, 113 и 125 Федерального закона от 26.10.2002 № 127-Ф3 «О несостоятельности (банкротстве)» устанавливают специальные правила по отношению к пункту 2 статьи 313 ГК РФ, в связи с чем исполнение обязательств должника его учредителями (участниками), собственником имущества должника - унитарного предприятия либо третьим лицом или третьими лицами после введения первой процедуры банкротства допускается с соблюдением порядка, предусмотренного законодательством о банкротстве».

\section{5. Отказ в прекращении процедуры банкротства при погашении третьим лицом задолженности перед всеми кредиторами в процедуре наблюдения}

Применение негативного правового подхода арбитражных судов приводит к тому, что суды отказывают в прекращении производства по делу о несостоятельности (банкротстве) по основанию, предусмотренному абзацем 7 пункта 1 статьи 57 Закона о банкротстве, при погашении третьим лицом всех требований.

В соответствии с абзацем 7 пункта 1 статьи 57 Закона о банкротстве арбитражный суд прекращает производство по делу о банкротстве в случае удовлетворения всех требований кредиторов, включенных в реестр требований кредиторов, в ходе любой процедуры, применяемой в деле о банкротстве.

Это положение закона прямо указывает на возможность прекращения производства по делу о банкротстве в ходе любой процедуры, применяемой в деле о банкротстве.

Буквальное толкование абзаца 7 пункта 1 статьи 57 Закона о банкротстве в отсутствие специальной нормы в главе IV «Наблюдение» Закона о банкротстве о возможности погашения задолженности третьим лицом не должно приводить к выводу о недопустимости погашения третьим лицом всех требований кредиторов и невозможности прекращения производства по делу в первой процедуре несостоятельности.

Иное приводило бы к ситуации, при которой должник в отсутствие законодательно закрепленного механизма реализации своего права, предусмотренного абзацем 7 пункта 1 статьи 57 Закона о банкротстве, не имел бы возможности указанное право реализовать.

В отсутствие такого механизма судам следует применять либо общий порядок погашения задолженности третьим лицом (статья 313 ГК РФ), либо специальные нормы о погашении задолженности в иных процедурах банкротства по аналогии (статьи 113 и 125 Закона о банкротстве).

Высший Арбитражный Суд Российской Федерации восполнил пробел в правовом регулировании и разъяснил порядок применения абзаца 7 пункта 1 статьи 57 Закона о банкротстве. Так, в соответствии с пунктом 11 Постановления Пленума Высшего Арбитражного Суда Российской Федерации от 22.06.2012 № 35 «О некоторых процессуальных вопросах, связанных с рассмотрением дел о банкротстве» (далее - Постановление Пленума № 35):

«В силу абзаца 6 пункта 1 статьи 57 Закона о банкротстве, суд прекращает производство по делу о банкротстве в случае отказа всех кредиторов, участвующих в деле о банкротстве, от заявленных требований. По смыслу этой нормы в процедуре наблюдения прекращение производства по делу по данному основанию возможно только после истечения срока для заявления требований (пункт 1 статьи 71 Закона о банкротстве). Если к моменту рассмотрения судом в ходе любой проиедуры банкротства вопроса о прекращении производства по делу по рассматриваемому основанию имеются предъявленные, но еще не рассмотренные требования, то для применения данного основания достаточно отказа от требований всех кредиторов, уже включенных в реетр, и не требуется отказа от заявленных, но не включенных в реестр требований. По общему правилу для применения абзаи, 6 пункта 1 статьи 57 Закона о банкротстве достаточно отказа только кредиторов, срок исполнения обязательств перед которыми наступил на дату рассмотрения судом вопроса о прекращении производства по делу; однако если будет установлено, что должник с учетом его текущего финансового состояния и разумных прогнозов его развития заведомо неспособен будет расплатиться по всем свочм, в том числе непросроченным, обязательствам, то суд в отсутствие отказа включенных в реестр кредиторов, срок исполнения обязательств перед которыми еще не наступил, на основании части 5 статьи 49 АПК РФ не принимает отказ кредиторов с наступившим сроком исполнения от своих требований.

Разбяснения, содержащиеся в предьдущем абзаце, применяются также при прекращении производства по делу на основании абзаца 7 пункта 1 статьи 57 Закона о банкротстве. Кроме того, для прекращения производства по делу по данному основанию необходимо, чтобы требования кредиторов были погашены только в части, включенной в реестр».

Предполагалось, что после принятия Постановления Пленума № 35 суды будут защищать интересы всех лиц, участвующих в деле о банкротстве (и кредиторов, и должников в равной степени).

Однако суды, следуя за практикой Верховного Суда Российской Федерации по конкретным делам (пункт 28 Обзора), не применяют разъяснения, указанные в Постановлении Пленума № 35, даже в тех ситуациях, в кото- 
рых такое применение очевидным образом защитило бы и кредиторов, и должников в равной степени (кредиторы получают полное удовлетворение требований, а должник не исключается из гражданского оборота).

В частности, суды отказывают в принятии исполнения обязательств должника третьим лицом при введенной процедуре наблюдения в делах, в которых имеется единственный кредитор.

\section{6. Проблематика исполнения обязательств третьим лицом в процедуре наблюдения перед единственным кредитором}

Применение негативного правового подхода арбитражных судов к ситуации с единственным кредитором все более укореняется в судебной практике.

Например, в деле компании ООО «Люберцы-Инвест», вопрос о признании которой банкротом был заявлен администрацией муниципального образования «городской округ Люберцы», отказано в признании погашения задолженности перед кредитором (администрацией) третьим лицом состоявшимся; при этом наличия других кредиторов, заявивших требования до и после введения процедуры наблюдения, установлено не было ${ }^{5}$.

С учетом пункта 28 Обзора в удовлетворении заявления ООО «Люберцы-Инвест» о прекращении производства по делу о банкротстве на основании абзаца 7 пункта 1 статьи 57 Закона о банкротстве (удовлетворения требований всех кредиторов) было отказано ${ }^{6}$

Непризнание судами состоявшимся перехода права требования к третьему лицу применительно к ситуации с единственным кредитором является неправомерным.

Кроме того, такое непризнание не соответствует целям и принципам института несостоятельности (банкротства).

1. Исполнение обязательств перед единственным кредитором третьим лицом в процедуре наблюдения не нарушает прав других кредиторов ввиду их отсутствия.

Соблюдение очередности и пропорциональности удовлетворения требований кредиторов является одним из основополагающих принципов института несостоятельности (банкротства) в Российской Федерации и, безусловно, находит свое отражение в том, что, по общему правилу, после введения первой процедуры банкротства погашение требований должника перед его кредиторами в индивидуальном порядке (требования отдельных кредиторов) в том числе по правилам статьи 313 Гражданского кодекса Российской Федерации недопустимо.

Действительно, действующим законодательством не предусмотрено удовлетворение в процедуре наблюдения требований отдельных кредиторов (за исключением требований по обязательным платежам ${ }^{7}$ ), поскольку это

\footnotetext{
Решение Арбитражного суда города Москвы от 23.06.2020 по делу № А40-155948/19-44-153«Б» (далее - Решение).

6 Дополнительным выводом суда послужила неспособность должника удовлетворить заявленные, но еще не рассмотренные требования единственного кредитора.

Порядок исполнения требований по обязательным платежам установлен ст. 71.1, 85.1, 112.1, 129.1 Закона о банкротстве.
}

может повлечь нарушение очередности и пропорциональности удовлетворения требований кредиторов ${ }^{8}$ и преимущественное удовлетворение требований одного кредитора перед другими кредиторами.

Более того, существует классическая доктринальная позиция о том, что «при установлении положений конкурсного права законодатель обязан стремиться прежде всего к равному удовлетворению всех кредиторов, к устранению всяких преимуществ» ${ }^{9}$.

С учетом этого при применении телеологического толкования (исходя из целей законодательного регулирования) норм Закона о банкротстве непринятие удовлетворения требований третьим лицом при множественности кредиторов может привести к нарушению принципов очередности и пропорциональности, поскольку остальные кредиторы не получат надлежащей правовой защиты.

Однако применение негативного правового подхода арбитражных судов представляется нецелесообразным в ситуациях с единственным кредитором.

Единственным правомерным интересом единственного кредитора в делах о несостоятельности (банкротстве) является удовлетворение в полном объеме своих требований. Как утверждает Ватлин Л.А., судебная практика исходит из того посыла, что кредитор не имеет иного основного материально-правового интереса в деле о банкротстве, нежели полное итоговое погашение заявленных им требований [1].

В случае получения полного удовлетворения своих требований у кредиторов отпадает подлежащий защите правовой интерес как в предложении кандидатуры арбитражного управляющего, так и в самом участии в деле о банкротстве $\mathrm{e}^{10}$.

Вместе с тем в отношении кредиторов, уклоняющихся от принятия исполнения, арбитражные суды делают вывод о неправомерности таких действий и злоупотреблении соответствующими правами на надлежащее исполнение обязательств ${ }^{11}$.

Таким образом, в гипотетической ситуации, в которой требования единственного кредитора в полной мере удовлетворяются третьим лицом, в случае если отсутствуют какие-либо признаки недобросовестности в таком исполнении, у такого кредитора пропадает какаялибо цель для продолжения участия в деле о банкротстве, нарушение его интересов объективно перестает существовать.

2. Поскольку исполнение обязательств перед единственным кредитором третьим лицом в процедуре наблюдения не может нарушить очередность и пропорциональность удовлетворения требований, статью 313

\footnotetext{
Принципы очередности и пропорциональности удовлетворения требований кредиторов неоднократно упоминались Верховным Судом Российской Федерации в своих судебных актах (см., например, Обзор судебной практики Верховного суда Российской Федерации № 3 (2016), утвержденный Президиумом Верховного Суда РФ от 19.10.2016).

Шершеневич Г.Ф. Курс торгового права. М., 2003. T. IV. С. 121

10 Определение Судебной коллегии по экономическим спорам Верховного Суда РФ от 25.01.2017 № 305-ЭС16-15945 по делу № A41-108121/2015.

11 Постановление Арбитражного суда Уральского округа от 15.07.2019 № Ф09-4026/19 по делу № А76-32823/2018.
} 
Гражданского кодекса Российской Федерации можно считать применимой к таким отношениям как общую норму в отсутствие специальной нормы (как уже было упомянуто ранее, Закон о банкротстве не содержит статьи, регулирующей порядок погашения требований третьими лицами в процедуре наблюдения).

Возможность применения пункта 2 статьи 313 Гражданского Кодекса Российской Федерации в процедурах банкротства (при отсутствии законодательно урегулированного порядка исполнения обязательств должника третьим лицом в таких процедурах) подтверждается и судебной практикой Верховного Суда Российской Федерации.

Так, в определении Верховного Суда Российской Федерации от 24.09.2018 № 305-ЭС18-9640 был применен пункт 2 статьи 313 Гражданского Кодекса Российской Федерации на стадии реализации имущества гражданина.

Указанный судебный акт впоследствии вошел в качестве пункта 18 в Обзор судебной практики Верховного Суда Российской Федерации № 4 (2018), утвержденный Президиумом Верховного Суда Российской Федерации 26.12.2018: «Суд не может отказать во включении в реестр требований кредиторов поручителя, признанного несостоятельным (банкротом), требования третьего лица, исполнившего основное обязательство в отсутствии возложения (подпункт 1 пункта 2 статьи 313 ГК РФ), со ссылкой на прекращение основного обязательства, поскольку в таком случае происходит замена в обязательстве прежнего кредитора на третье лицо (пункт 5 статьи 313 ГК РФ). При этом третье лицо обладает правом на включение своего требования в реестр требований кредиторов как основного должника, так и поручителя».

3. Поскольку исполнение обязательств перед единственным кредитором третьим лицом в процедуре наблюдения не может нарушить принципы равенства [5], очередность и пропорциональность удовлетворения требований, специальные нормы Закона о банкротстве, регулирующие порядок удовлетворения требований третьими лицами в иных процедурах, могут применяться по аналогии.

Как уже было ранее оговорено, общие нормы Закона о банкротстве в отношении исполнения обязательств должника собственником имущества должника - унитарного предприятия, учредителями (участниками) должника либо третьим лицом или третьими лицами изложены в статьях 113 и 125 Закона о банкротстве.

Согласно пункту 1 статьи 113 Закона о банкротстве «Учредители (участники) должника, собственник имущества должника - унитарного предприятия либо третье лицо или третьи лица в любое время до окончания внешнего управления в целях прекращения производства по делу о банкротстве вправе удовлетворить все требования кредиторов, включенные в реестр требований кредиторов, или предоставить должнику денежные средства, достаточные для удовлетворения всех требований кредиторов в соответствии с реестром требований кредиторов».

В соответствии с пунктом 1 статьи 125 Закона о банкротстве «Собственник имущества должника унитарного предприятия, учредители (участники) должника либо третье лицо или третьи лица в любое время до окончания конкурсного производства вправе одновременно удовлетворить все требования кредиторов в соответствии с реестром требований кредиторов или предоставить должнику денежные средства, достаточные для удовлетворения всех требований кредиторов в соответствии с реестром требований кредиторов в порядке и на условиях, которые предусмотрены статьей 113 настоящего Федерального закона».

Таким образом, Закон о банкротстве устанавливает ряд общих требований к порядку исполнения обязательств должника собственником имущества должника - унитарного предприятия, учредителями (участниками) должника либо третьим лицом или третьими лицами в процедурах внешнего управления и конкурсного производства.

Такими требованиями являются: одновременное (1) удовлетворение всех требований кредиторов (2), включенных в реестр требований (3).

В отсутствие такого регулирования в процедуре наблюдения, учитывая, что вышеуказанные требования при погашении задолженности третьим лицом перед единственным кредитором соблюдаются в полной мере, положения пункта 1 статьи 113 и пункта 1 статьи 125 3акона о банкротстве должны применяться по аналогии.

Без привязки к ситуации с единственным кредитором аналогичная позиция высказывалась и в доктрине: «при отсутствии специальных правил об исполнении обязательства третьим лицом можно применить правила статьи 113 Закона о банкротстве по аналогии» [2].

4. Пункт 1 статьи 71.1 Закона о банкротстве нельзя однозначно отнести к императивной норме.

Статьей 71.1 Закона о банкротстве установлен порядок погашения учредителями (участниками) должника, собственником имущества должника - унитарного предприятия и (или) третьим лицом задолженности по обязательным платежам в ходе наблюдения.

Однако данная норма не содержит запрет на погашение обычной задолженности должника (не относящейся к обязательным платежам) третьими лицами. В силу этого, а также с учетом целей законодательного регулирования статья 71.1 Закона о банкротстве допускает погашение обычной задолженности должника третьими лицами.

Иное приводило бы к нарушению принципов очередности и пропорциональности между обычным кредитором и публичным кредитором (государства, муниципального образования, субъекта РФ).

5. Применение негативного правового подхода арбитражных судов в делах о банкротстве с участием единственного кредитора не обеспечивает соблюдения интересов не только должника, но и кредитора, вследствие чего противоречит идеям и принципам несостоятельности.

Сплошное следование негативному правовому подходу арбитражных судов в ситуациях с единственным кредитором лишь в угоду единообразию правоприменения недопустимо, поскольку последнее предполагает единообразное разрешение дел только в случаях правильного и законного правоприменения [6].

Негативным правовым подходом арбитражных судов в рассматриваемом случае нарушается принцип 
справедливости в рамках несостоятельности (банкротства), который выражается в том числе в справедливости погашения долгов ${ }^{12}$.

Следует отметить, что, по мнению исследователей, в настоящее время вероятность погашения требований кредитора в ходе проведения процедуры несостоятельности (банкротства) организации продолжает оставаться на крайне низком уровне. По результатам процедур конкурсного производства требования кредиторов остаются неудовлетворенными в $68 \%$ дел. Доля погашенных требований кредиторов от общей суммы заявленных требований составляет 4,7\%. По данным инвентаризаций, перед процедурой банкротства имущество отсутствует у $37 \%$ должников [7]. По данным статистики Федресурса, сохраняется ликвидационная направленность банкротного процесса: реабилитационные процедуры (финансовое оздоровление и внешнее управление) вводятся лишь в $1 \%$ случаев $^{13}$.

Отказ судов от принятия исполнения третьим лицом обязательств должника перед единственным кредитором приведет к тому, что в реестре требований кредиторов будет содержаться требование, которое фактически исполнено.

Одновременно с этим в отношении должника (при отсутствии фактически неисполненных требований кредиторов) будет введено конкурсное производство, что приведет к ликвидации должника и прекращению его хозяйственной деятельности (в случае невозможности восстановления платежеспособности должника).

Более того, в таком случае будут нарушены основные цели института несостоятельности (банкротства), а именно:

(1) защита публичных интересов (наибольшее благоприятствование публичным интересам путем установления в п. 1 ст. 71.1 Закона о банкротстве возможности уплаты обязательных платежей на стадии наблюдения);

(2) ограничение злоупотреблений правом со стороны третьих лиц, удовлетворяющих требования кредиторов (выведен в п. 17 Обзора судебной практики ВС РФ № 2, утв. Президиумом ВС РФ 26.04.2017);

(3) обеспечение очередности удовлетворения кредиторов (ст. 16, ст. 61.3, ст. 71 и другие статьи Закона о банкротстве);

(4) обеспечение пропорциональности удовлетворения кредиторов (ст. 16, п. 8 ст. 142, п. 3 ст. 142.1, п. 5 ст. 142 , П. 4 ст. 189.96 Закона о банкротстве);

(5) наиболее полное и справедливое погашение долгов (п. 2 ст. 71.1, п. 2 ст. 85.1, ст. 113, ст. 125, п. 1 ст. 141 Закона о банкротстве);

(6) обеспечение возможности сохранения действующего хозяйствующего субъекта (ст. 2, ст. 70, ст. 75 Закона о банкротстве, и также выведен в Определении Верховного Суда РФ от 25.01.2017 № 305-ЭС16-15945 по делу № A41-108121/2015) [8];

12 Например, о принципе справедливого погашения долгов сказано в Постановлении Арбитражного суда Уральского округа от 17.04.2018 № Ф09-233/18.

13 Банкротства компаний - статистика Федресурса за 2019 год // Федресурс. URL: https://fedresurs.ru/news/7b3c8884-b159-4ee7-b5fb7770d9d941da
(7) соблюдение баланса интересов должника и кредиторов (общегражданский принцип, распространившийся почти на все положения Закона о банкротстве, формально выведен в Постановлении Пленума Высшего Арбитражного Суда РФ от 14.03.2014 № 16 «О свободе договора и ее пределах»);

(8) принцип социальной справедливости [9].

По справедливому замечанию Фагмановой Э.И., «немаловажно, чтобы идеалы единообразия судебной практики не затмевали собой реальные негативные последствия функционирования механизмов его обеспечения» $[10]$.

\section{Вывод}

Авторами проанализирована правоприменительная практика арбитражных судов в делах о несостоятельности (банкротстве) юридических лиц в части отказа в признании надлежащим исполнения обязательств должника третьими лицами после введения первой процедуры банкротства (наблюдения) и сделан вывод о наличии общего негативного правового подхода арбитражных судов, согласно которому не допускается погашение задолженности третьими лицами после введения первой процедуры банкротства.

Авторы выявили несколько предпосылок формирования негативного правового подхода арбитражных судов. Основной предпосылкой формирования правового подхода о недопустимости погашения долга третьим лицом в первой процедуре банкротства является институт запрета злоупотребления правом, на основе которого арбитражные суды обосновывают признание лица банкротом поддержанием стабильного рыночного оборота. При этом чаще всего суды подкрепляют свои выводы ссылкой на пункт 28 Обзора судебной практики по вопросам, связанным с участием уполномоченных органов в делах о банкротстве и применяемых в этих делах процедурах банкротства, утвержденного Президиумом Верховного Суда РФ 20.12.2016.

Концептуальный недостаток такого подхода заключается в том, что правовым последствием его применения является прекращение деятельности юридического лица при принципиальной возможности его сохранения в отсутствие нарушения прав кредиторов. В этом случае не достигается основная цель института несостоятельности (банкротства) - сохранение хозяйствующего субъекта при удовлетворении требований кредиторов.

В конечном счете негативный правовой подход арбитражных судов направлен на сохранение нежелательной актуальной тенденции в судебно-арбитражной практике - ликвидационной направленности банкротного процесса.

Однако, как было показано авторами, возможность сохранения хозяйствующего субъекта зависит от количества кредиторов в деле о банкротстве.

Если в деле о банкротстве имеется лишь один кредитор, требования которого удовлетворены третьим лицом, права других кредиторов не нарушаются (ввиду их отсутствия). В таком случае арбитражные суды должны признавать надлежащим исполнение обязательств 
должника третьими лицами после введения первой процедуры банкротства (наблюдения).

Таким образом, представляется, что общим правовым подходом судов должно являться стремление к сохранению хозяйствующих субъектов. В связи с этим авторами обоснована недопустимость отказа в удовлетворении ходатайства о прекращении производства по делу при полном удовлетворении реестровых требований единственного кредитора.

\title{
Литература
}

1. Ватлин Л.А. Институт исполнения обязательства третьим лицом в законодательстве о несостоятельности (банкротстве) // Вестник арбитражной практики. 2020. № 6. С. 27-34.

2. Петров Д.А. Проблемы исполнения обязательств должника-банкрота третьим лицом или учредителем // Информационноаналитический журнал «Арбитражные споры». 2018. № 4. С. 126-136.

3. Тихонова В. Третье лицо заплатило за должника: почему это опасно для кредитора в банкротстве и как ему отстоять свои интересы? // ЭЖ-Юрист. 2018. № 48 (1049).

4. Суворов Е.Д. Банкротство в практике Верховного Суда Российской Федерации и Высшего Арбитражного Суда Российской Федерации: энциклопедия правовых позиций за 2014-2018 гг. М. : Статут, 2019. Вып. 2. 447 с.

5. Суворов Е.Д. Принцип равенства кредиторов как инструмент выявления злоупотреблений в банкротстве: равное равным, различное различным // Закон. 2020. № 9. С. 39-52.

6. ук П.А., Коршунова П.В. Единство судебной практики как особая ценность правосудия // Журнал российского права. 2020. № 12. С. $103-118$.

7. Чуприков М.В., Николаева А.А. Проблемные вопросы правовой квалификации отношений, связанных с привлечением контролирующих должника лиц к субсидиарной ответственности // Арбитражный и гражданский процесс. 2020 . № 6. C. $49-54$.

8. Правовое регулирование экономических отношений. Несостоятельность (банкротство) / под ред. Е.П. Губина, С.А. Карелиной. М. : Статут, 2018. 256 с.

9. Институт несостоятельности (банкротства) в правовой системе России и зарубежных стран: теория и практика правоприменения : монография / А.Б. Баранова, А.З. Бобылева, В.А. Вайпан и др.; отв. ред. С.А. Карелина, И.В. Фролов. М. : Юстицинформ, 2020. $360 \mathrm{c}$.

10. Фагманова Э.И. Подходы к пониманию категории «единообразие судебной практики» // Арбитражный и гражданский процесс. 2019. № 12. С. 28-32.

\section{SATISFACTION OF OBLIGATIONS TO THE SOLE CREDITOR BY A THIRD PARTY AFTER INTRODUCING THE INSOLVENCY SUPERVISION REGIME}

\author{
V. Zaitsev ${ }^{14}$, A. Kravchenko'15, V. Bedrosov ${ }^{16}$
}

Keywords: insolvency (bankruptcy), insolvency supervision regime, priority and proportionality of satisfaction of claims, sole creditor, acting in good faith, Supreme Court of the Russian Federation, court practice.

\section{Abstract.}

Purpose of the work: assessing problems of satisfying the debtor's obligations to the sole creditor by a third party considering the legal stances of supreme court instances, general legal and private law principles, and identifying conceptual problems in using the said approach in cases of legal entities' insolvency (bankruptcy) involving a sole creditor.

Methods of study: the methodological basis of the study was the universal dialectical method of cognition as well as the general and specific research methods based on it and the formal logical method.

Results of study. An analysis of commercial court law enforcement practice in insolvency (bankruptcy) proceedings regarding a refusal to recognise satisfying the debtor's obligations by third parties as being proper after introducing the first bankruptcy proceeding, i. e. insolvency supervision, is of primary importance in achieving the purpose of the work.

14 Vladimir Zaitsev, Dr.Sc. (Law), Professor at the Department of Legal Support for Market Economy of the School of Law of the Institute of Public Administration and Civil Service of the Russian Presidential Academy of National Economy and Public Administration, Moscow, Russian Federation. E-mail: vzaytsev@ranepa.ru (sections6 and Conclusion).

15 Aleksandr Kravchenko, Ph.D. (Law), Associate Professor at the Department of Legal Support for Market Economy of the School of Law of the Institute of Public Administration and Civil Service of the Russian Presidential Academy of National Economy and Public Administration, Moscow, Russian Federation. E-mail: aa.kravchenko@igsu.ru (sections 4-5).

16 Vladislav Bedrosov, Master in Civil Law, Ph.D. student at the School of Law of the Institute of Public Administration and Civil Service of the Russian Presidential Academy of National Economy and Public Administration, Moscow, Russian Federation. E-mail: ve.bedrosov@gmail.com (sections 1-3). 
The main tendencies in applying Paragraph 28 of the of the Supreme Court Law Review on the inadmissibility of repaying debts by third persons after introducing the first bankruptcy proceeding without taking into account the number of creditors in the bankruptcy case are considered in the work. The authors identified significant conceptual flaws of applying the said provisions in cases involving a sole creditor the debtor's obligations to whom are satisfied in full by a third party.

In the first part of the paper, general provisions concerning repaying a debt by a third person in case of insolvency of the debtor being a legal entity as well as prerequisites for forming a legal approach of inadmissibility of such repayment in the course of the first bankruptcy proceeding are identified.

In the second part of the paper, the essence of the said approach in commercial court practice concerning satisfying the debtor's obligations to the sole creditor by a third party, the reasons for refusals by the courts to recognise such satisfaction as being proper as well as the legal consequences of the said refusal are determined.

In the final part of the paper, the authors give special attention to the legal justification of inadmissibility of a refusal to satisfy an application for terminating the insolvency proceedings if all of the sole creditor's claims are satisfied in full.

\section{References}

1. Vatlin L.A. Institut ispolneniia obiazatel'stva tret'im litsom v zakonodatel'stve o nesostoiatel'nosti (bankrotstve). Vestnik arbitrazhnoi praktiki, 2020, No. 6, pp. 27-34.

2. Petrov D.A. Problemy ispolneniia obiazatel'stv dolzhnika-bankrota tret'im litsom ili uchreditelem. Informatsionno-analiticheskii zhurnal "Arbitrazhnye spory", 2018, No. 4, pp. 126-136.

3. Tikhonova V. Tret'e litso zaplatilo za dolzhnika: pochemu eto opasno dlia kreditora $\mathrm{v}$ bankrotstve i kak emu otstoiat' svoi interesy? EZh-Iurist, 2018, No. 48 (1049).

4. Suvorov E.D. Bankrotstvo v praktike Verkhovnogo Suda Rossiiskoi Federatsii i Vysshego Arbitrazhnogo Suda Rossiiskoi Federatsii: entsiklopediia pravovykh pozitsii za 2014-2018 gg. M. : Statut, 2019. Vyp. 2. 447 pp.

5. Suvorov E.D. Printsip ravenstva kreditorov kak instrument vyiavleniia zloupotreblenii v bankrotstve: ravnoe ravnym, razlichnoe razlichnym. Zakon, 2020, No. 9, pp. 39-52.

6. Guk P.A., Korshunova P.V. Edinstvo sudebnoi praktiki kak osobaia tsennost' pravosudiia. Zhurnal rossiiskogo prava, 2020, No. 12, pp. 103-118.

7. Chuprikov M.V., Nikolaeva A.A. Problemnye voprosy pravovoi kvalifikatsii otnoshenii, sviazannykh s privlecheniem kontroliruiushchikh dolzhnika lits k subsidiarnoi otvetstvennosti. Arbitrazhnyi i grazhdanskii protsess, 2020, No. 6, pp. 49-54.

8. Pravovoe regulirovanie ekonomicheskikh otnoshenii. Nesostoiatel'nost' (bankrotstvo). pod red. E.P. Gubina, S.A. Karelinoi. M. : Statut, 2018. $256 \mathrm{pp}$.

9. Institut nesostoiatel'nosti (bankrotstva) v pravovoi sisteme Rossii i zarubezhnykh stran: teoriia i praktika pravoprimeneniia : monografiia. A.B. Baranova, A.Z. Bobyleva, V.A. Vaipan i dr.; otv. red. S.A. Karelina, I.V. Frolov. M. : Iustitsinform, 2020.360 pp.

10. Fagmanova E.I. Podkhody k ponimaniiu kategorii "edinoobrazie sudebnoi praktiki". Arbitrazhnyi i grazhdanskii protsess, 2019, No. 12 , pp. 28-32. 


\section{ПЕРСПЕКТИВЫ И ПРАВОВЫЕ ПРОБЛЕМЫ РАЗВИТИЯ МИКРОГЕНЕРАЦИИ в России}

Коданева С. И. ${ }^{1}$

Ключевые слова: распределенная энергетика, микрогрид, Интернет энергии, интеллектуальная энергетика, блокчейн, договор купли-продажи электрической энергии, присоединение к энергосети, рынок электроэнергии, умный город.

\section{Аннотация.}

Цель работы: анализ действующего законодательства в области микрогенерации, изучение зарубежного опыта развития микрогридов, в том числе с использованием блокчейн, а также определение потенциала развития микрогенерации в РФ и необходимых для этого изменений в действующем законодательстве.

Метод исследования: в работе использованы общенаучные и специальные методы научного познания. Методы логического анализа, анализа законодательства, научной и деловой литературы, сравнительного анализа, систематизации, обобщения, системного подхода были использованы для достижения поставленных в работе целей.

Результаты исследования: распределенная микрогенерация имеет достаточно высокий потенциал развития в России, прежде всего на территориях, не входящих в Единую энергетическую систему, а также в удаленных сельских поселениях. Необходимая нормативная база для развития микрогенерации была сформирована только в 2021 г. Вместе с тем проведенный анализ позволил выявить недостатки существующего правового регулирования, которые будут тормозить развитие микрогенерации в РФ. Наиболее перспективной технологией для устранения этих недостатков, а также повышения прозрачности, надежности и качества обмена электроэнергией при одновременном снижении стоимости такого обмена является блокчейн. Однако для реализации проектов в данной области потребуется внесение изменений как в законодательство об электроэнергетике (в части установления правового статуса, порядка функционирования и взаимодействия микрогридов с существующей энергетической системой России), так и в гражданское законодательство и законодательство о финансовых рынках (в части определения статуса NFT-токенов для торговли объемами энергии и возможности использования токенов в качестве платежного средства за потребленную энергию в микрогридах).

DOI: 10.21681/2226-0692-2021-4-40-48

\section{Введение и постановка задачи}

$\Pi$ ный нам мир, и эти изменения продолжаются. Мнот представления об образе жизни, работе, формах общения, казавшиеся традиционными и незыблемыми, сегодня оказались опровергнутыми. Люди стали гораздо чаще пользоваться сервисами доставки на дом. Средства индивидуальной мобильности, совсем недавно бывшие редкостью, теперь вытесняют пешеходов с улиц городов, удаленная работа становится все более распространенной нормой.

Под влиянием этих факторов могут произойти структурные изменения спроса на энергию и существенные изменения в традиционном энергобалансе. Так, снижение мобильности уже привело к снижению в 2020 г. спроса на бензин и авиатопливо. Происходит снижение энергопотребления в промышленности при одновременном росте ее потребления в жилом секторе (это связано отчасти с работой из дома, а отчасти с тем, что 2020 г. стал вторым самым теплым годом в истории метеонаблюдений $)^{2}$.

Все большее признание и распространение получают концепции «умных городов», комфортной внешней среды и просьюмеризма, основанные на широком распространении современных цифровых, зеленых технологий, а также меняющейся роли жителей, превращении их в «активных граждан», которые не только потребляют предлагаемые им продукты и услуги, но и сами принимают участие в их создании. Примерами тому могут служить мобильные приложения, позволяющие находить попутчиков для поездок в автомобилях, система Creative Commons для бесплатного использования программ с

\footnotetext{
2 Ends earth's warmest 10 years on record // Met Office. 2020. 14.01. URL: https://www.metoffice.gov.uk/about-us/press-office/news/weather-andclimate/2021/2020-ends-earths-warmest-10-years-on-record (дата обращения 23.10.2021).
} 
открытым кодом. В энергетике все большее распространение, особенно в европейских странах, получает микрогенерация, основанная, прежде всего, на использовании возобновляемых источников энергии. Параллельные тенденции формирования распределенной энергетики и микрогридов в сочетании с расширяющимся внедрением современных технологий, таких как литий-ионные аккумуляторы и блокчейн, все больше размывают границы существующих энергосистем, а также меняют роль основных участников энергетического рынка

Вместе с тем в Российской Федерации данное явление пока не получило достаточно широкого распространения как в силу технических причин, так и недостатков правового регулирования взаимодействия между поставщиками и потребителями электроэнергии. Настоящая статья посвящена анализу указанных причин и факторов, препятствующих развитию микрогенерации в России.

\section{Решение задачи}

С принятием в 2019 году Федерального закона № 471-Ф3 «О внесении изменений в Федеральный закон «Об электроэнергетике» в части развития микрогенерации» в законодательстве Российской Федерации получило закрепление определение микрогенерации, под которой понимается «объект по производству электрической энергии, принадлежащий на праве собственности или ином законном основании потребителю электрической энергии, энергопринимающие устройства которого технологически присоединены к объектам электросетевого хозяйства с уровнем напряжения до 1000 B, функционирующий в том числе на основе использования возобновляемых источников энергии и используемый указанным потребителем для производства электрической энергии в целях удовлетворения собственных бытовых и (или) производственных нужд, а также в целях продажи в порядке, установленном основными положениями функционирования розничных рынков, в случае, если объем выдачи электрической энергии таким объектом по производству электрической энергии в электрическую сеть не превышает величину максимальной присоединенной мощности энергопринимающих устройств указанного потребителя и составляет не более 15 киловатт и если для выдачи электрической энергии такого объекта в электрическую сеть не используется электрическое оборудование, предназначенное для обслуживания более одного помещения в здании, в том числе входящее в состав общего имущества многоквартирного дома» ${ }^{4}$. Однако до марта 2021 года, когда была сформирована необходимая подзаконная нормативная база, указанный федеральный закон фактически оставался неработаю-

\footnotetext{
Большинство аналитиков едины во мнении, что сценарии, отвечающие целям Парижского соглашения по ограничению выбросов, приведут к значительному спросу на металлы. Например, для производства альтернативных источников энергии (ветряков и солнечных панелей) меди в перерасчете на 1 МВт требуется в четыре раза больше, чем для генераторов на ископаемом топливе. (Прим. редакции)

4 Федеральный закон от 27.12.2019 № 471-Ф3 «О внесении изменений в Федеральный закон «Об электроэнергетике» в части развития микрогенерации» // СПС «КонсультантПлюс». URL: http://www. consultant.ru (дата обращения 28.10.21 г.).
}

щим, поскольку он не давал ответа на вопросы о том, как будет осуществляться подключение объекта микрогенерации к сети и рассчитываться плата за потребляемую его владельцем электроэнергию из централизованной сети и поставляемую в сеть энергию. С принятием Постановления Правительства РФ от 2 марта 2021 г. № 299 «О внесении изменений в некоторые акты Правительства Российской Федерации в части определения особенностей правового регулирования отношений по функционированию объектов микрогенерации» получили правовое регулирование некоторые процедурные вопросы. Однако сохраняется необходимость в анализе действующего законодательства Российской Федерации с точки зрения формирования полной и эффективной нормативной базы для развития умных распределенных сетей микрогенерации - микрогридов.

\section{Потенциал развития микрогенерации в Российской Федерации}

Прежде всего, необходимо обратиться к обсуждению вопроса о том, является ли микрогенерация эффективным решением задачи энергетической обеспеченности в такой традиционно углеводородной стране, как Россия, где стоимость ископаемого топлива относительно невысока, а большинство потребителей получают электроэнергию из централизованных систем.

Здесь следует отметить, что в России существуют зоны, которые не входят в Единую энергетическую систему, где либо формируются собственные энергосистемы, либо приходится реализовывать дорогостоящие мероприятия по обеспечению данных территорий электроэнергией (к примеру, через Северный завоз). Более того, как отмечают Е.В. Слепцова и С.Т. Максумова, примерно 70\% территории страны не имеют энергетической инфраструктуры, что делает дорогим подключение к сетям и необходимым энергетическую поддержку живущего здесь населения [1].

Однако использование микрогенерации вполне может оправдать себя и в границах функционирования Единой энергетической системы. Так, С.М. Никоноров и И.С. Мокрышев показывают, что, по данным Росстата, в России насчитывается около 40 млн частных домов, и если каждый из них установит хотя бы по 5 кВт собственной генерации, то это снизит нагрузку на всю энергосистему России больше чем наполовину. Более того, по данным Росстата, на население приходится 14,3\% общего потребления электроэнергии, а на долю потерь в сетях электропередачи - до 10\% всей произведенной электроэнергии. Таким образом, внедрение систем микрогенерации и самообеспечения электроэнергии может почти на четверть сократить выработку электроэнергии [2].

При этом Э.С. Варич и Н.С. Рисположенская наглядно демонстрируют, что Россия обладает достаточно высоким уровнем инсоляции. В некоторых районах среднегодовой приход солнечной радиации достигает в день 4-5 кВт.ч/ М $^{2}$ (что соизмеримо со странами - лидерами по введению солнечных систем, Германией и Испанией). При этом уровень инсоляции в России высок не только на юге, но также в Сибири, Дальнем Востоке и в Забайкалье - в этих регионах количество солнечных 


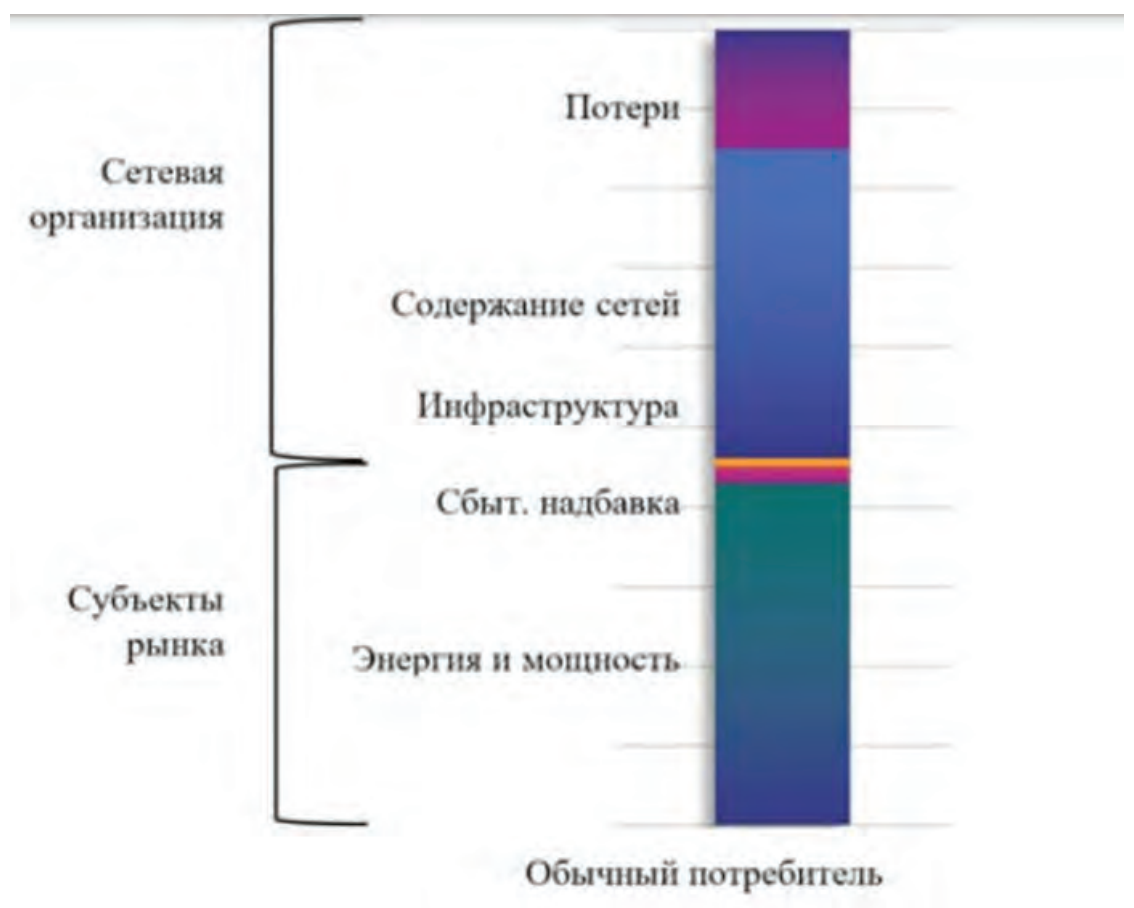

Рис. 1. Состав платы за электроэнергию конечного потребителя [2].

дней в году доходит до 300. Ресурсы ветровой энергии России не уступают солнечной: скорость ветра по территории России достигает 5-6,5 м/с. Ветроэнергетика является одним из наиболее перспективных направлений в России, и, по данным Российской ассоциации ветроиндустрии, может составить $10 \%$ от всего производства электроэнергии страны. Соответственно, рынок ветроэнергетики, по оценкам специалистов, в РФ к 2024 году может составить 3,6 ГВт с оборотом порядка 200 млрд рублей [3].

Обсуждая развитие микрогенерации в России, следует отметить, что на сегодняшний день широко распространено мнение о том, что она является заведомо более дорогой, чем традиционная энергетика. В связи с этим следует учитывать, что потребитель платит не только за саму энергию, которую он потребляет, но также многочисленные надбавки. Так, в ценовых зонах с нерегулируемыми ценами энергия торгуется на оптовом рынке, где ее продают и покупают только участники оптового рынка. Потребителям энергию продают сбытовые компании, которые фактически выступают посредниками, за что получают сбытовую надбавку. Помимо этого, энергию необходимо передавать от продавца к потребителю, чем занимаются сетевые организации, которые взимают плату за содержание сетей, а также несколько инфраструктурных надбавок, которые взимаются для реализации государственных программ в электроэнергетике или работы резервных электростанций. Причем плата за содержание сетей является самой крупной надбавкой к стоимости электроэнергии, которая может быть даже больше, чем сама стоимость электроэнергии. Более того, в инфраструктурных выплатах и других надбавках конечный потребитель платит за электростанции, которые содержатся в резервном статусе, т. е. «на всякий случай», и оплачивают мощность на оптовом рынке [2] (рис. 1).

Развитие микрогенерации позволит владельцам экономить на указанных надбавках сбытовых и сетевых организаций. Кроме того, по мере развития технологий в области возобновляемой энергетики они будут становиться все более дешевыми. Так, цены на солнечные фотоэлектрические модули (PV) за последнее десятилетие снизились примерно на 90\% [4]. Международное энергетическое агентство (МЭА) объявило солнечную энергию «новым королем» мировых рынков электроэнергии, самым дешевым источником электроэнергии в истории 5 . По данным Агентства, солнечная энергетика - это самый быстрорастущий сегмент мировой электроэнергетики. Так, ожидается, что в 2021 г. будет введено в эксплуатацию 145 ГВт, а в 2022 г. 162 ГВт мощностей ${ }^{6}$.

Цены на наземные ветряные турбины снизились на 55-60\% с 2010 года. В 2020 г. глобальный прирост ветровых мощностей увеличился более чем на $90 \%$ и достиг $114 \Gamma \mathrm{Bт}^{7}$. В 2019 году впервые в истории большая часть новых мощностей по производству электроэнергии в мире была произведена за счет солнечной и ветровой генерации [5].

По мнению МЭА, в 2021-2022 годах на возобновляемые источники энергии будет приходиться $90 \%$ роста новых мощностей во всем мире. Это объясняется

World Energy Outlook // IEA. 2020. URL: https://www.iea.org/reports/ world-energy-outlook-2020 (дата обращения 08.10.2021).

6 Renewable Energy Market Update 2021. Outlook for 2021 and 2022 (2021) // IEA. 2021. URL: https://www.iea.org/reports/renewableenergy-market-update-2021 (дата обращения 08.10.2021).

Там же. 
тем, что в настоящее время дешевле построить новые ветровые или солнечные мощности, чем продолжать эксплуатировать $60 \%$ существующих угольных электростанций ${ }^{8}$.

За последнее десятилетие цена на литий-ионные аккумуляторы также упала на $89 \%$ и составляет в среднем 137 долларов США за кВт.ч. Для некоторых китайских электрических автобусов цены на батареи составили менее 100 долларов США за кВт.ч, что делает электромобили конкурентоспособными по стоимости с традиционными автомобилями․ Данная технология используется также для хранения электроэнергии, выработанной из возобновляемых источников, что повышает их производительность.

Произведенные согласно мировой практике расчеты нормированной стоимости электроэнергии (LCOE) показали, что в средней полосе России этот показатель равен от 3 до 4,5 P (рублей) для сетевой солнечной электростанции и 7-8 Р для гибридной солнечной электростанции. Учитывая, что средняя ставка на дневной тариф у населения в центральной полосе России варьируется от 5 до 6 ₹а кВт.ч, данный проект сетевых вариантов исполнения без добавления аккумулирующих мощностей является экономически эффективным ${ }^{10}[2]$.

\section{Анализ нормативно-правовой базы по использованию микрогенерации в Российской Федерации}

Несмотря на показанный выше значительный потенциал, развитие микрогенерации в России до недавнего времени сдерживалось отсутствием необходимой нормативной базы. Фактически не существовало ни оснований, ни условий, ни порядка подключения объектов микрогенерации к централизованной сети, также как и порядка определения стоимости произведенной на таких объектах электроэнергии. Постановление Правительства РФ от 2 марта 2021 г. № 299 «О внесении изменений в некоторые акты Правительства Российской Федерации в части определения особенностей правового регулирования отношений по функционированию объектов микрогенерации» создало механизмы для реализации Федерального закона о микрогенерации, принятого еще в 2019 г. и до сих пор не работавшего. Таким образом, только спустя два года после законодательного закрепления права населения и предприятий поставлять в сеть электроэнергию, выработанную возобновляемыми источниками энергии (ВИЭ), была сформирована необходимая подзаконная нормативная база, содержащая

8 Coal developers risk $\$ 600$ billion as renewables outcompete worldwide // Carbon Tracker. 12.03.2020. URL: https://carbontracker.org/coaldevelopers-risk-600-billion-as-renewables-outcompete-worldwide/ (дата обращения 08.10.2021).

9 Battery Pack Prices Cited Below \$100/kWh for the First Time in 2020, While Market Average Sits at \$137/kWh // BloombergNEF. 16.12.2020. URL: https://about.bnef.com/blog/battery-pack-prices-cited-below100-kwh-for-the-first-time-in-2020-while-market-average-sits-at-137$\mathrm{kwh}$ / (дата обращения 08.10.2021).

10 В этих расчетах не учтены затраты на захоронение и переработку отходов отслуживших ветряков и солнечных панелей, а особенно аккумуляторов, без которых невозможно предоставлять потребителю качественную энергию. (Прим. редакции) методические указания о том, что признается объектом микрогенерации, как подключать, сальдировать и потреблять электроэнергию его собственникам.

Однако анализ действующего законодательства позволяет выявить ряд ограничений для полноценного развития микрогенерации в России. Так, установленная максимальная мощность источника не должна превышать 15 кВт, что, по мнению В.П. Камышанского, неоправданно: «современный жилой дом или квартира для комфортного проживания, как правило, насыщены различными объектами сложной бытовой техники, в том числе системой кондиционирования, теплыми полами, которые по объему потребления пиковых нагрузок нередко уже не вписываются в 15 киловатт электрической энергии». Он подчеркивает, что «в настоящее время разумнее поднять этот предел до 25 кВт» [6, с. 15].

Следует добавить заложенное в законодательстве условие о том, что «объем выдачи электрической энергии таким объектом по производству электрической энергии в электрическую сеть не превышает величину максимальной присоединенной мощности энергопринимающих устройств указанного потребителя» ${ }^{11}$. С учетом практики развития микрогридов в зарубежных странах (подробнее об этом - ниже), данное условие является совершенно неоправданным ограничением, особенно если учесть, что в соответствии с нормами, содержащимися в Федеральном законе № 471-Ф3, объект микрогенерации может у себя установить не только физическое лицо для удовлетворения своих бытовых нужд, но также юридическое лицо и ИП для удовлетворения производственных нужд. Соответственно, на практике вполне вероятна ситуация, когда собственник здания устанавливает у себя на крыше и на своем земельном участке солнечные панели, которые будут вырабатывать энергии больше, чем присоединенная мощность, что по мере развития солнечной генерации, включая ее мощность, является вполне реалистичным.

Здесь же следует обратить внимание на формулировку Федерального закона о том, что электрическое оборудование должно быть предназначено для обслуживания не более одного помещения в здании. Данное требование представляется по меньшей мере странным, если применить его для случаев установления объектов микрогенерации в частных домах (где заведомо больше одного помещения, не говоря уже о различных вспомогательных постройках, таких как кухня, баня, гараж и т. п.), в гаражных кооперативах (которые объединяют гаражи и хозяйственные постройки, такие как погреба и сараи) или на производственных объектах (например, небольшой магазин или цех по пошиву одежды или производству иного товара со складом для хранения продукции). Таким образом, фактически возможность использования микрогенерации в частном жилом секторе, в сельской местности и на производственных объектах оказывается под вопросом. Вместе с тем именно микрогенерация может стать эффективным источником электроэнергии для субъектов малого и среднего бизнеса,

\footnotetext{
Федеральный закон от 27.12.2019 № 471-Ф3 «О внесении изменений в Федеральный закон «Об электроэнергетике» в части развития микрогенерации» // CПC «КонсультантПлюс». URL: http:// www.consultant.ru (дата обращения 28.10.21 г.).
} 
особенно в сельских районах, а также на территориях, не входящих в Единую энергетическую систему России.

Кроме того, в законодательстве заложены явно дискриминационные условия по отношению к владельцам объектов микрогенерации, поскольку работа таких объектов, как известно, нестабильна. Соответственно, в определенные моменты времени (например, в солнечные или ветреные дни) они могут производить больше 15 кВт, в то время как в другие периоды они вообще не будут производить электроэнергию. Однако в первом случае сетевая компания имеет право дистанционно отключать объект микрогенерации, чтобы энергия с него не поступала в сеть. А в другие периоды времени, когда его мощности будет недостаточно, потребитель будет вынужден покупать энергию у гарантирующего поставщика. При этом цены на поставляемую и потребляемую энергию будут различаться в разы, поскольку в соответствии с Постановление Правительства РФ от 4 мая 2012 г. № 442 «О функционировании розничных рынков электрической энергии, полном и (или) частичном ограничении режима потребления электрической энергии» гарантирующий поставщик обязан заключить с владельцем объекта микрогенерации договор купли-продажи электроэнергии «по ценам, не превышающим средневзвешенную стоимость единицы электрической энергии (мощности), приобретаемой гарантирующим поставщиком в аналогичном объеме на оптовом рынке» ${ }^{12}$. Таким образом, потребитель будет платить гарантирующему поставщику за потребляемую энергию розничную цену, включающую, как было показано выше, различные надбавки (сумма которых может превосходить стоимость собственно потребленной энергии), а гарантирующий поставщик будет платить потребителю оптовую или даже более низкую (с учетом формулировки «не превышающим») цену, не включающую все эти надбавки.

Как отмечает В.П. Камышанский, «предусмотренный в данном случае порядок ценообразования нельзя признать справедливым, способным стимулировать развитие микрогенерации в России. В законе заложены правила, которые ни при каких обстоятельствах не смогут обеспечить экономическую выгоду от такой деятельности собственникам или иным владельцам при эксплуатации объектов микрогенерации. В условиях применения таких правил развитие микрогенерации в нашей стране будет заведомо планово-убыточным» [6].

Нельзя полностью согласиться с данной точкой зрения, поскольку в существующих сегодня в России условиях главным стимулом для внедрения микрогенерации как раз и является экономия на потерях электроэнергии в сетях, а также на выплате надбавок сетевым и сбытовым компаниям. Представляется, что потребители будут заинтересованы в использовании данных объектов в первую очередь для собственных нужд и только во вторую - для продажи энергии.

\footnotetext{
2 Постановлением Правительства РФ от 4 мая 2012 г. № $442 « \mathrm{O}$ функционировании розничных рынков электрической энергии, полном и (или) частичном ограничении режима потребления электрической энергии» // CПС «КонсультантПлюс». URL: http://www. consultant.ru (дата обращения 28.10.21 г.).
}

\section{Анализ перспективных направлений развития и технологий для микрогенерации}

Однако технологии не стоят на месте, и по мере их развития и увеличения количества пользователей будет формироваться, как уже было отмечено выше, принципиально новая модель энергетики - модель микрогридов (а в будущем, потенциально, и супергридов) или так называемого Интернета энергии - концепции, которая предполагает создание локальной энергетической инфраструктуры, в которую интегрируются производители и потребители энергии и в рамках которой они могут свободно обмениваться энергией. Микрогрид (MicroGrid) - система, которая включает собственные источники генерации энергии и в кризисные ситуации способна взять на себя задачу удовлетворения спроса потребителей. Это своего рода уменьшенная версия централизованной системы электроснабжения. Микрогрид, как правило, работает при подключении к общей центральной сети, но в любой момент он может отключиться и работать за счет своей собственной генерации энергии ${ }^{13}$.

Сегодня в зарубежных странах, прежде всего в Европе и США, такие концепции получают все более широкое внедрение в рамках реализации проектов умного города. Одной из целей интеллектуальной энергосистемы для умного города является содействие местному производству и местному потреблению энергии. Таким образом, это позволяет избежать потерь энергии при транспортировке на большие расстояния.

Следует отметить, что данная концепция тесно вплетается в формирующуюся сегодня цифровую экономику, активно задействуя основные ее технологии. Так, по мере роста внимания к интеллектуальной энергии у технологии блокчейн появилась возможность создать более устойчивую среду для всей энергетической отрасли. Это объясняется тем, что Интернет энергии построен на архитектуре, которая, в отличие от традиционной, представляет собой децентрализованную электроэнергетическую систему. Здесь реализовано интеллектуальное управление потоками электроэнергии, осуществляемое за счет одноранговых энергетических транзакций между ее пользователями. Энергетическая транзакция - акт взаимодействия двух и более субъектов микроэнергосистемы (микрогрида), который состоит из трех слоев энергоинформационного обмена: финансово-договорного, информационно-управляющего и физического (электрического).

Технологические особенности блокчейна как нельзя лучше соответствуют задаче создания одноранговой Р2Р-сети ${ }^{14}$ производства и потребления энергии. Интеллектуальные энергетические системы могут использовать блокчейн для сохранения конфиденциальности пользователей, что позволяет им контролировать потребленную и произведенную энергию, т. е. свой

\footnotetext{
3 Интернет энергии. MicroGrid. Малая распределенная энергетика // Tadviser. 27.02.2020. URL: http://www.tadviser.ru/index.php/ Статья:Интернет_энергии_(MicroGrid)_Малая_распределенная_ энергетика (дата обращения 28.10.21 г.)

14 Р2P, англ. peer-to-peer - прямые транзакции от человека к человеку, между производителем и потребителем.
} 
энергобаланс, одновременно обеспечивая борьбу с мошенничеством (продажа или покупка необоснованного количества энергии).

Блокчейн создает одноранговые энергетические обмены между жителями умного города посредством заключения смарт-контрактов на покупку и продажу энергии. Потенциально это позволит кардинально снизить роль гарантирующего поставщика как централизованного оператора сети. В городе может быть несколько микрогридов на базе блокчейн, которые «разговаривают» друг с другом. Так, например, в Бруклине компания LO3 Energy в сотрудничестве с ConsenSys построила микрогриды на основе блокчейна, которые соединяли дома с солнечными панелями на крышах с соседями, которые хотели купить зеленую энергию, вырабатываемую по соседству. Граждане должны были установить интеллектуальные счетчики, которые могли бы отслеживать выработанную и потребленную энергию. Эти одноранговые энергетические транзакции сами по себе создали местную энергетическую экономику [7].

Еще одним примером является проект системного оператора TenneT, энергокомпании Vandebron и производителя домашних накопителей Sonnen. Они запустили пилотный проект по использованию домашних накопителей и батарей в электромобилях и для регулирования частоты в энергосистеме [8].

Переход к распределенной энергетике с использованием технологии блокчейн в России позволит устранить недостатки существующей системы, когда просьюмер не может выбрать, по какой цене, у кого и в какое время покупать электроэнергию, а также по какой цене, кому и в какое время продать излишек произведенной или накопленной электроэнергии. В то же время формирование микрогридов позволит создать для владельцев объектов микрогенерации более прозрачные и справедливые условия участия в энергетическом рынке, сделает участие потребителей в производстве электроэнергии экономически обоснованным и выгодным без государственного стимулирования и помощи посредников в лице сбытовой компании. Таким образом, в перспективе сбытовая надбавка гарантирующего поставщика при покупке электроэнергии у просьюмера полностью ликвидируется, что, в свою очередь, снизит стоимость электроэнергии для конечного потребителя. Снижение стоимости электроэнергии достигается также за счет частичного исключения платы за услуги по ее передаче, которые составляют значительную часть ее цены [10].

При этом расчеты между участниками сети могут происходить как с помощью традиционных безналичных денег, так и с использованием криптовалюты, а сама энергия может торговаться в виде NFT-токенов. Параллельно блокчейн позволяет запускать проекты микрофинансирования объектов генерации. Так, проект Gimede (победитель в отборе стартап-программы компании Enel) предложил модель полного цикла возврата инвестиций от объектов возобновляемой энергетики, так называемый BSO (Build, Sell and Operate) [8].

Наконец, как было отмечено выше, блокчейн полезен в регулировании преобразования и распределения энергии в интеллектуальной сети, обеспечивая бо́льшую прозрачность энергетических транзакций. Децентрализованный характер объектов, генерирующих зеленую энергию, соответствует способности блокчейна упростить процесс сбора, проверки и предоставления данных о мощности в энергетической компании и происхождении энергии, что имеет немаловажное значение для системы углеводородного налога, которую планирует ввести ЕС. Многие эксперты признают, что отсутствие в России собственной системы регулирования выбросов приведет к тому, что российские экспортеры ряда отраслей будут платить цену за углерод в бюджет EC, а со временем, возможно, также в бюджет США и азиатских стран (аналоги европейской системы торговли выбросами уже введены в Японии, Корее и ряде провинций Китая) [11]. По оценкам Boston Consulting Group, налог на импорт в ЕС в размере 30 долларов США за метрическую тонну выбросов $\mathrm{CO}_{2}$ может сократить пул прибыли иностранных производителей примерно на 20\% [12]. Согласно исследованию компании КПМГ, в результате введения налога российские производители могут потерять от 6 до 50 млрд евро за период до 2030 года, в зависимости от применяемых способов взимания сбора.

В целях нивелирования этих рисков для российских компаний-экспортеров необходимо срочно сформировать механизмы, которые позволят им доказать низкий углеродный след своей продукции. Одним из таких механизмов, реализуемых рядом стран Европы, в частности, Великобританией, является торговля зелеными сертификатами, которые подтверждают, что потребляемая компанией энергия произведена с помощью ВИЭ. Так, проект SolarCoin генерирует сертификаты за каждый МВт·ч чистой энергии.

Конечно, данное направление использования технологии блокчейн представляет интерес скорее для крупной генерации на основе ВИЭ, что выходит за рамки настоящего исследования. Однако, во-первых, воспользоваться зелеными сертификатами могут и субъекты малого и среднего бизнеса, экспортирующие свои товары в Европу и потребляющие энергию, произведенную с помощью микрогенерации. А во-вторых, приведенный пример показывает, что при комплексном подходе и достаточно большом масштабе микрогриды на базе блокчейн могут решать разноуровневые и многоплановые задачи.

Кроме того, как показывают научные исследования, сети блокчейн позволят решить еще одну проблему, с которой уже сегодня сталкивается российская энергетическая система. Дело в том, что особенностью просьюмеров является наличие силового преобразователя (инвертора). Каждый инвертор - отдельный центр принятия решений. Неконтролируемое взаимодействие таких устройств друг с другом и с сетью может приводить к сбоям. Поэтому с целью обеспечения безаварийной и устойчивой работы сети Белгородский филиал «Россети Центр» разрабатывает электросетевой контроллер для управления системами накопления электрической энергии (СНЭ) и объектами микрогенерации (просьюмерами) в сетях $0,4 \mathrm{~KB}^{15}$. В то же время H. Treiblmaier et al. [13]

Белгородские энергетики разрабатывают универсальный электросетевой контроллер для управления просьюмерами // КомерсантЪ 03.02.2021. URL: https://www.kommersant.ru/doc/4672992 (дата обращения 26.10.21). 
утверждают, что использование энергетических тегов на основе блокчейна в транзакционных процессах может напрямую подключать несколько энергетических ресурсов и бытовых приборов, предоставляя пользователям высококачественную, недорогую и эффективную энергию в любом месте и в любое время. Блокчейн обеспечивает прочную коммуникационную основу, которую можно использовать в энергетической сети для оптимизации и обеспечения безопасности процессов торговли энергией Р2P [14].

\section{Выводы}

Проведенный в рамках настоящего исследования анализ позволил установить, что хотя Российская Федерация является традиционно углеводородной страной, энергетическая система которой преимущественно централизована и функционирует на основе ископаемого топлива, распределенная микрогенерация имеет достаточно высокий потенциал развития, прежде всего на территориях, не входящих в Единую энергетическую систему, а также в удаленных сельских поселениях, где стоимость доставки элекроэнергии и соответствующие сбытовые и инфраструктурные надбавки превосходят стоимость самой энергии. Однако на сегодняшний момент микрогенерация в России развита довольно слабо. Это обусловлено, во-первых, невысокой осведомленностью потребителей о реальной стоимости и доступности технологий солнечной и ветровой энергетики, а во- вторых, тем, что необходимая нормативная база была сформирована только в марте 2021 г.

Анализ нормативно-правовой базы позволил выявить ряд существенных недостатков, которые могут стать сдерживающими факторами для развития микрогенерации в России, поскольку владельцы объектов микрогенерации вынуждены заключать договоры с гарантирующими поставщиками на тех условиях, которые определены в действующем законодательстве и носят заведомо невыгодный для них характер.

Вместе с тем анализ зарубежного опыта показывает, что по мере увеличения количества объектов микрогенерации возникнет потенциал для формирования мигрогридов и постепенного внедрения Интернета энергии. В работе показано, что наиболее перспективной технологией для повышения прозрачности, надежности и качества обмена электроэнергией при одновременном снижении стоимости такого обмена является блокчейн.

Однако для реализации проектов в данной области потребуется внесение изменений как в законодательство об электроэнергетике (в части установления правового статуса, порядка функционирования и взаимодействия микрогридов с существующей энергетической системой России), так и в гражданское законодательство и законодательство о финансовых рынках (в части определения статуса NFT-токенов для торговли объемами энергии и возможности использования токенов в качестве платежного средства за потребленную энергию в микрогридах).

\section{Литература}

1. Слепцова Е.В., Максумова С.Т. Финансовые инструменты государственной поддержки рынка возобновляемых источников энергии в России // Экономика и бизнес: теория и практика. 2021. № 4-2 (74). С. 162-165. DOI: 10.24412/2411-0450-2021-4-2-162-165 .

2. Никоноров С.М., Мокрышев И.С. Микрогенерация в России: анализ экономической и правовой структур // Экономика устойчивого развития. 2021. № 3(47). С. 109_115. DOI: 10.37124/20799136_2021_3_47_109.

3. Варич Э.С., Рисположенская Н.С. Современное состояние ВИЭ на территории России: причины, тенденции и перспективы развития // Научные труды КубГТУ. 2020. № 8. С. 430—438.

4. Roser M. Why did renewables become so cheap so fast? And what can we do to use this global opportunity for green growth? // Our World in Data. 01.12.2020. URL: https://ourworldindata.org/cheap-renewables-growth (дата обращения 08.10.2021).

5. Eckhouse B. World Added More Solar, Wind Than Anything Else Last Year // Bloomberg Green. 01.09.2020. URL: https://www.bloomberg.com/news/ articles/2020-09-01/the-world-added-more-solar-wind-than-anything-else-last-year?sref=FSwei2xh (дата обращения 08.10.2021).

6. Камышанский В.П. О микрогенерации в российском энергетическом праве: надежды и разочарования // Власть закона. 2020. № 2(42). C. $13-17$.

7. Kundu D. Blockchain and Trust in a Smart City // Environment and Urbanization ASIA. 2019. Vol. 10, Issue 1. P. 31-43. URL: https://doi. org/10.1177/0975425319832392 (дата обращения 15.10.2021).

8. 8. Пердеро А. Как создать блокчейн-энергетику // Нефтегазовая вертикаль. URL: http://www.ngv.ru/magazines/article/kak-sozdatblokcheyn-energetiku/ (дата обращения 28.10.21 г.).

9. Болотов П.В. Применение технологии блокчейн в распределенной генерации на основе возобновляемых источников энергии // Управление качеством. 2021. № 8. С. $38-43$.

10. Бобылев П.М., Семейкин А.Ю. «Зеленый» протекционизм Европы // Энергетическая политика. 2020. № 10(152). C. 24-33. DOI: 10.46920/24095516_2020_10152_24.

11. Кутырев Г.И., Апасова А.М. Пограничный корректирующий механизм ЕС как фактор влияния на внешнеэкономическую деятельность РФ // Вестник Московского Университета им. С.Ю. Витте. Серия 1: Экономика и управление. 2020. № 4(35). C. 58-65. DOI: 10.21777/2587-554X2020-4-58-65.

12. Treiblmaier H., Rejeb A., Strebinger A. Blockchain as a Driver for Smart City Development: Application Fields and a Comprehensive Research Agenda // Smart Cities. 2020. Vol. 3. P. 853-872. URL: https://doi.org/10.3390/smartcities3030044 (дата обращения 08.10.2021).

13. Jindal A., Aujla G.S., Kumar N. SURVIVOR: A blockchain based edge-as-a-service framework for secure energy trading in SDN-enabled vehicle-togrid environment // Computer Networks. 2019. Vol. 153. P. 36-48. URL: https://doi.org/10.1016/j.сотnet.2019.02.002 (дата обращения 15.10.2021). 


\section{Prospects for and legal problems of microgeneration deVelopment In Russia}

\section{S. Kodaneva ${ }^{16}$}

Keywords: distributed energy, microgrid, Internet of Energy, smart energy, blockchain, purchase and sale contract for electric power, power grid connection, electricity market, smart city.

\section{Abstract.}

Purpose of the work: analysing the current laws in the field of microgeneration, studying the foreign experience in microgrid development, including based on blockchain as well as determining the potential for development of microgeneration in the Russian Federation and the changes to be made for this in the current laws.

Method of study: general scientific and special methods of cognition are used in the work. Methods of logical analysis, analysis of laws, research and business literature, comparative analysis, systematisation, generalisation, and system approach were used to achieve the goals set in the work.

Results of study: distributed microgeneration has a fairly high potential for development in Russia, primarily in territories that are not part of the Unified Power System of Russia as well as in remote rural settlements. The necessary regulatory framework for the development of microgeneration was formed only in 2021. At the same time, the analysis carried out made it possible to identify the shortcomings of the existing legal regulation which would hinder the development of microgeneration in the Russian Federation. The most promising technology for eliminating these shortcomings as well as increasing the transparency, reliability and quality of electricity exchange while at the same time bringing down the costs of the exchange is blockchain. However, implementing projects in this field will require amendments to the legislation on electric power industry (as regards establishing the legal status, procedure for microgrid functioning and interaction with the existing power system of Russia), civil legislation and legislation on financial markets (as regards determining the status of NFT tokens for trading volumes of energy and the possibilities of using tokens as a means of payment for energy consumed in microgrids).

\section{References}

1. Sleptsova E.V., Maksumova S.T. Finansovye instrumenty gosudarstvennoi podderzhki rynka vozobnovliaemykh istochnikov energii v Rossii. Ekonomika i biznes: teoriia i praktika, 2021, No. 4-2 (74), pp. 162-165. DOI: 10.24412/2411-0450-2021-4-2-162-165 .

2. Nikonorov S.M., Mokryshev I.S. Mikrogeneratsiia v Rossii: analiz ekonomicheskoi i pravovoi struktur. Ekonomika ustoichivogo razvitiia, 2021, No. 3(47), pp. 109-115. DOI: 10.37124/20799136_2021_3_47_109.

3. Varich E.S., Rispolozhenskaia N.S. Sovremennoe sostoianie VIE na territorii Rossii: prichiny, tendentsii i perspektivy razvitiia. Nauchnye trudy KubGTU, 2020, No. 8, pp. 430-438.

4. Roser M. Why did renewables become so cheap so fast? And what can we do to use this global opportunity for green growth? Our World in Data, 01.12.2020. URL: https://ourworldindata.org/cheap-renewables-growth (data obrashcheniia 08.10.2021).

5. Eckhouse B. World Added More Solar, Wind Than Anything Else Last Year. Bloomberg Green, 01.09.2020. URL: https://www. bloomberg.com/news/articles/2020-09-01/the-world-added-more-solar-wind-than-anything-else-last-year?sref=FSwei2xh (data obrashcheniia 08.10.2021).

6. Kamyshanskii V.P. O mikrogeneratsii v rossiiskom energeticheskom prave: nadezhdy i razocharovaniia. Vlast' zakona, 2020 , No. 2(42), pp. 13-17.

7. Kundu D. Blockchain and Trust in a Smart City. Environment and Urbanization ASIA, 2019, vol. 10, issue 1, p. 31-43. URL: https:// doi.org/10.1177/0975425319832392 (data obrashcheniia 15.10.2021).

8. Perdero A. Kak sozdat' blokchein-energetiku. Neftegazovaia vertikal'. URL: http://www.ngv.ru/magazines/article/kak-sozdatblokcheyn-energetiku/ (data obrashcheniia 28.10.21 g.).

9. Bolotov P.V. Primenenie tekhnologii blokchein v raspredelennoi generatsii na osnove vozobnovliaemykh istochnikov energii. Upravlenie kachestvom, 2021, No. 8, pp. 38-43.

10. Bobylev P.M., Semeikin A.Iu. "Zelenyi” protektsionizm Evropy. Energeticheskaia politika, 2020, No. 10(152), pp. 24-33. DOI: 10.46920/2409-5516_2020_10152_24.

16 Svetlana Kodaneva, Ph.D. (Law), Leading Researcher at the Department of Jurisprudence of the Institute of Scientific Information on Social Sciences of the Russian Academy of Sciences, Associate Professor at the Department of Civil Law Disciplines of Gubkin Russian State University of Oil and Gas (National Research University), Moscow, Russian Federation. E-mail: kodanevas@gmail.com 
11. Kutyrev G.I., Apasova A.M. Pogranichnyi korrektiruiushchii mekhanizm ES kak faktor vliianiia na vneshneekonomicheskuiu deiatel'nost' RF. Vestnik Moskovskogo Universiteta im. S.Iu. Vitte, seriia 1: Ekonomika i upravlenie, 2020, No. 4(35), pp. 58-65. DOI: 10.21777/2587-554X-2020-4-58-65.

12. Treiblmaier H., Rejeb A., Strebinger A. Blockchain as a Driver for Smart City Development: Application Fields and a Comprehensive Research Agenda. Smart Cities, 2020, vol. 3, p. 853-872. URL: https://doi.org/10.3390/smartcities3030044 (data obrashcheniia 08.10.2021).

13. Jindal A., Aujla G.S., Kumar N. SURVIVOR: A blockchain based edge-as-a-service framework for secure energy trading in SDN-enabled vehicle-to-grid environment. Computer Networks, 2019, vol. 153, p. 36-48. URL: https://doi.org/10.1016/j.comnet.2019.02.002 (data obrashcheniia 15.10.2021). 


\section{ЗАКОНОДАТЕЛЬСТВО О КЛИМАТЕ В УСЛОВИЯХ ЭНЕРГОПЕРЕХОДА К НИЗКОУГЛЕРОДНОЙ ЭКОНОМИКЕ}

Карцхия А. А. ${ }^{1}$

Ключевые слова: климатическая повестка, климатическое право, корпоративное управление, энергетическое право, зеленая энергетика.

\section{Аннотация.}

Цель работы: анализ современных международных соглашений (конвенций) и национального законодательства в сфере энергетики и изменений климата для определения закономерностей формирования и выявления особенностей этой области правового регулирования.

Метод исследования: применение системного анализа действующего законодательства и правовых доктрин в сочетании со сравнительно-правовым анализом изучаемой сферы правового регулирования, включая российское и зарубежное законодательство, а также международно-правовые акты.

Результаты исследования: автор приходит к заключению, что под влиянием глобальных мегатрендов, связанных с изменениями окружающего мира, трансформацией экономики и технологического развития в условиях борьбы с мировой пандемией климатическая повестка вышла на первый план в международных отношениях и сопровождается активной законотворческой деятельностью во многих странах мира. Национальные стратегии и новые тенденции моделей управления стимулируют внедрение низкоуглеродных технологий и снижение выбросов парниковых газов, разработку технологий на основе возобновляемых источников энергии. Создается система международных актов и национального законодательства в области глобальной защиты климата планеты и регулирования негативного воздействия антропогенных факторов в деятельности государств и корпораций. Происходит создание нового направления правового регулирования - климатического права, которое, по мнению автора, формирует новый вектор конкурентных отношений с участием государств, частных корпораций и других участников глобального перехода от традиционной энергетики к энергетике ВИЭ.

DOI: 10.21681/2226-0692-2021-4-49-55

\section{Введение}

C оцениваются как самая большая глобальная угроза, а вызванные агрессивным антропогенным воздействием экологические проблемы, по оценкам OECD [1], приводят к деградации окружающей среды, чрезмерному загрязнению воздуха, нехватки воды и утраты биоразнообразия, подрывают мировые экосистемы. Высокие темпы экономического роста последних десятилетий породили новые глобальные мегатренды - урбанизацию и изменение климата, которые сильно изменили глобальную структуру выбросов углерода, бо́льшая часть которых приходится на мировой энергетический сектор и промышленность. Кризисные явления усугубляются влиянием мировой пандемии КОВИД-19 и стали катализатором перестройки экономических и социальных моделей развития как на международном уровне, так и в масштабе национальных экономик.

Климатическая повестка, как констатируется в Концепции развития водородной энергетики в Российской Федерации ${ }^{2}$ становится значимым фактором изменений

2 Распоряжение Правительства РФ от 05.08.2021 № 2162-p «Об в мировой экономике и энергетике. В качестве одной из приоритетных целей мировой экономики рассматриваются замедление процесса глобального потепления, а также развитие отраслей экономики при низком уровне выбросов парниковых газов (низкоуглеродная экономика).

Вместе с тем в условиях стагнации и рецессии ведущих экономик мира, снижения устойчивости мировой валютно-финансовой системы, обострения борьбы за доступ к рынкам и ресурсам, как отмечается в Стратегии национальной безопасности Российской Федерации ${ }^{3}$, все бо́льшее распространение получает практика использования инструментов недобросовестной конкуренции, протекционистских мер и санкций, в том числе в финансовой и торговой сферах. Повышенное внимание

утверждении Концепции развития водородной энергетики в Российской Федерации» // Собрание законодательства Российской Федерации. 2021. № 33. Ст. 6124.

3 Указ Президента РФ от 02.07.2021 № 400 «О Стратегии национальной безопасности Российской Федерации» // Собрание законодательства Российской Федерации. 2021. № 27. Ст. 5351.

\footnotetext{
Карцхия Александр Амиранович, доктор юридических наук, профессор РГУ нефти и газа (НИУ) им. И.М. Губкина, г. Москва, Российская Федерация. E-mail: arhz50@mail.ru
} 
мирового сообщества к проблемам изменения климата и сохранения благоприятной окружающей среды используется в качестве предлога для ограничения доступа российских компаний к экспортным рынкам, сдерживания развития российской промышленности, установления контроля над транспортными маршрутами, воспрепятствования освоению Россией Арктики (п. 16). Изменения климата оказывают всё более негативное влияние на условия ведения хозяйственной деятельности и состояние среды проживания человека. Возрастает частота опасных природных явлений и процессов, которые становятся источниками возникновения чрезвычайных ситуаций природного и техногенного характера (п. 79). Развитие «зеленой» и низкоуглеродной экономики становится главным вопросом в международной повестке дня. Возрастающая конкуренция за доступ к природным ресурсам - один из факторов усиления международной напряженности и возникновения конфликтов между государствами (п. 81). В качестве одной из стратегических задач Российская Федерация рассматривает свою территорию, ее ландшафтное и биологическое разнообразие, уникальный эколого-ресурсный потенциал как национальное достояние, сохранение и защита которого необходимы для обеспечения жизни будущих поколений, гармоничного развития человека и реализации права граждан на благоприятную окружающую среду. Сохранение атмосферного воздуха и воды, отвечающих экологическим стандартам качества, рекультивация нарушенных земель, экологическая реабилитация территорий и водных объектов, увеличение площади лесовосстановления, ликвидация накопленного вреда окружающей среде являются обязательными условиями для улучшения качества жизни в Российской Федерации (п. 82).

При этом следует учитывать, что Россия входит в пятерку крупнейших эмитентов парниковых газов в мире после Китая, США, Индии, Японии и консолидированно 27 стран ЕС + Великобритании, на которые в совокупности приходится 51\% населения Земли, 62,5\% мирового валового внутреннего продукта, $62 \%$ от общего мирового потребления ископаемого топлива и $67 \%$ выбросов от общего мирового ископаемого $\mathrm{CO}_{2}$ [2]

Тем не менее, большинство мировых аналитиков энергетических рынков сходятся во мнении, что топливом, способным выполнить роль «переходного топлива» к углеродно-нейтральной экономике в будущем, является природный газ, а развитие газовой генерации как резервного источника энергии является дополнительным фактором развития возобновляемых источников энергии. К 2030 году общее потребление энергии в мире вырастет на 16\% по сравнению с уровнем 2020 года, потребление нефти - на $19 \%$, природного газа - на $18 \%$, а потребление угля будет планомерно снижаться и опустится ниже уровня 2020 года ${ }^{4}$.

\section{Правовое регулирование климатических вопросов: возможности и перспективы}

Правовое регулирование вопросов климатической повести имеет свои особенности, связанные с раз-

\footnotetext{
4 Распоряжение Правительства РФ от 16.03.2021 № 640-р «О долгосрочной программе развития производства сжиженного природного газа в Российской Федерации» // Собрание законодательства Российской Федерации. 2021. № 13. Ст. 2273.
}

работкой национального законодательства и международно-правовых актов, специфики применения климатического права.

В условиях противостояния негативным последствиям глобальных мегатрендов важную роль играет принятый в сентябре 2015 года Генеральной Ассамблеей $\mathrm{OOH}$ документ «Преобразование нашего мира: Повестка дня в области устойчивого развития на период до 2030 г.», которым 196 стран участниц установили 17 глобальных целей устойчивого развития (ЦУР) [3], включающие следующие положения:

(1) повсеместная ликвидация нищеты во всех её формах;

(2) ликвидация голода, обеспечение продовольственной безопасности, улучшение питания и содействие устойчивому развитию сельского хозяйства;

(3) обеспечение здорового образа жизни и содействия благополучию для всех в любом возрасте;

(4) обеспечение всеохватного и справедливого качественного образования и поощрение возможности обучения на протяжении всей жизни для всех;

(5) обеспечение гендерного равенства и расширение прав и возможностей всех женщин и девочек;

(6) обеспечение наличия и рационального использования водных ресурсов и санитарии для всех;

(7) обеспечение доступа к недорогостоящим, надежным, устойчивым и современным источникам энергии для всех;

(8) содействие неуклонному, всеохватному и устойчивому экономическому росту, полной и производительной занятости и достойной работе для всех;

(9) создание прочной инфраструктуры, содействие обеспечению всеохватной и устойчивой индустриализации и внедрению инноваций;

(10) снижение уровня неравенства внутри стран и между ними;

(11) обеспечение открытости, безопасности, жизнестойкости и устойчивости городов и населенных пунктов;

(12) обеспечение рациональных моделей потребления и производства;

(13) принятие срочных мер по борьбе с изменением климата и его последствиями;

(14) сохранение и рациональное использование океанов, морей и морских ресурсов в интересах устойчивого развития;

(15) защита, восстановление экосистем суши и содействие их рациональному использованию, рациональное управление лесами, борьба с опустыниванием, прекращение и обращение вспять процесса деградации земель и прекращение процесса утраты биологического разнообразия;

(16) содействие построению миролюбивых и открытых обществ в интересах устойчивого развития, обеспечение доступа к правосудию для всех и создание эффективных, подотчетных и основанных на широком участии учреждений на всех уровнях;

(17) укрепление средств достижения устойчивого развития и активизация работы механизмов глобального партнерства в интересах устойчивого развития.

В достижении ЦУР ключевая роль отведена бизнесу, который в своей деятельности: 
(1) определяет бизнес-стратегии с учетом ценностей корпоративной социальной ответственности, международных требований к защите прав человека и трудовых отношений, антикоррупции и др.;

(2) соответствует запросам инвесторов и «зеленого» финансирования для получения доступа к глобальным финансовым и сырьевым рынкам;

(3) обеспечивает реализацию стратегии климатической низкоуглеродной повестки;

(4) совершенствует свои бизнес-модели в целях устойчивости своего развития и территорий присутствия компаний, благополучия общества и развития экономики.

Дополнением к целям ЦУР служит созданный в рамках ООН в 2000 году Глобальный договор (United Nations Global Compact) как международная инициатива для бизнеса в сфере корпоративной социальной ответственности и устойчивого развития. Участниками Глобального договора $\mathrm{OOH}$ (ГД ООН) являются, прежде всего, компании любых форм собственности, а также некоммерческие организации, реализующие цели устойчивого развития, которые публично заявляют о поддержке этой инициативы и принимают обязательства участников ГД ООН, выполнение которых подтверждается регулярным публичными отчетами. В настоящее время ГД ООН объединяет более 12000 участников из 166 стран мира ${ }^{5}$.

В основе ГД ООН лежат десять принципов в области прав человека, трудовых отношений, охраны окружающей среды и борьбы с коррупцией [4] на базе Всеобщей декларации прав человека, Декларации Международной организации труда об основополагающих принципах и правах в сфере труда, Декларации по окружающей среде и развитию (Рио-де-Жанейро) и Конвенции ООН против коррупции. К принципам ГД ООН относятся:

Права человека.

Принцип 1: Деловые круги должны поддерживать и уважать защиту провозглашенных на международном уровне прав человека.

Принцип 2: Деловые круги не должны быть причастны к нарушениям прав человека.

Трудовые отношения.

Принцип 3: Деловые круги должны поддерживать свободу объединения и реальное признание права на заключение коллективных договоров.

Принцип 4: Деловые круги должны выступать за ликвидацию всех форм принудительного и обязательного труда.

Принцип 5: Деловые круги должны выступать за полное искоренение детского труда.

Принцип 6: Деловые круги должны выступать за ликвидацию дискриминации в сфере труда и занятости. Охрана окружающей средь.

Принцип 7: Деловые круги должны поддерживать подход к экологическим вопросам, основанный на принципе предосторожности.

Принцип 8: Деловые круги должны предпринимать инициативы, направленные на повышение ответственности за состояние окружающей среды.

URL: http://globalcompact.ru/about
Принцип 9: Деловые круги должны содействовать развитию и распространению экологически безопасных технологий.

Борьба с коррупщией.

Принцип 10: Деловые круги должны противостоять всем формам коррупции, включая вымогательство и взяточничество.

Универсальный характер ЦУР позволяет компаниям выбрать тот набор целей, которые наилучшим образом вписываются в их деятельность и создаваемые программы развития как на глобальном уровне, так и на уровне каждой страны.

Глобальный договор ООН призывает компании максимально активно выступать за прорывные инновации и внедрять их, с тем чтобы таким образом бизнес помог миру наиболее эффективным образом достичь целей устойчивого развития и уже сегодня получить выигрышные коммерческие возможности завтрашнего дня.

Как правило, участие в ГД ООН рассматривается компаниями как возможность продвижения принципов корпоративной социальной ответственности в деловом сообществе, проведения политики цивилизованного и прозрачного ведения бизнеса, совершенствования методов корпоративного управления и реализации ответственного подхода к инвестированию. В рамках отдельно взятых стран действуют свои объединения участников. Российская часть ГД ООН основана в 2008 году и насчитывает на сегодняшний день более 80 участников, включая компании крупного бизнеса, такие как ПАО «НК «Роснефть», ОК Русал, АФК «Система», ПАО «РЖД», ПАО «Лукойл», ФК «Уралсиб», НГ «Сахалин Энерджи», аффилированные компании «Филипп Моррис Инт.» и другие, а также малые и средние предприятия, деловые ассоциации, некоммерческие неправительственные организации и академические институты [5].

Корпоративная политика декарбонизации активно проводится во многих ведущих мировых компаниях, включая нефтегазовый сектор: British Petroleum c запуском «зеленого» бренда Helios, англо-голландская компания Shell, норвежская компания Statoil преобразовалась в многоплановую энергетическую компанию Equinor. Нефтегазовые компании по всему миру всё более активно внедряют меры декарбонизации в систему корпоративного управления, устанавливают целевые показатели по декарбонизации, а также способствуют развитию добровольной системы мониторинга, независимого аудита, раскрытия климатической отчетности.

Климатическая повестка становится одной из основных доминант в международных отношениях после заключения 196 странами в декабре 2015 г. Парижского соглашения по климату (Paris Climate Agreement, 2015). Целью этого многостороннего международного договора является значительное ограничение глобального потепления по сравнению с доиндустриальными уровнями, которое достигается за счет общемирового снижения выбросов парниковых газов, чтобы достичь климатически нейтрального мира (net zero) к 2050 г. Ключевым компонентом Парижского соглашения является статья 2, в которой ставится цель удержать повышение глобальной средней температуры на уровне не выше $2{ }^{\circ} \mathrm{C}$ от доиндустриального уровня и продолжать усилия 
по ограничению повышения температуры до $1,5^{\circ} \mathrm{C}$ в сравнении с доиндустриальным уровнем.

Реализация столь амбиционной цели потребует существенных экономических, социальных и технологических преобразований, которые должны осуществить страны-участницы в рамках 5-летних циклов с учетом наращивания финансового и технического потенциала нуждающихся стран в рамках Парижского соглашения по климату (далее - Парижское соглашение).

Для выполнения Парижского соглашения решающее значение будет иметь применение в энергетическом секторе технологий смягчения последствий изменения климата, таких как улавливание, использование и хранение углерода, которые позволяют улавливать углерод в месте выброса и обеспечить его безопасное хранение под землей. При этом выбросы углерода высасываются из атмосферы, а добываемый природный газ используется для достижения чистого нуля (net zero) углеродных выбросов. В этом смысле основными изменениями в энергетическом секторе являются два фактора. Во-первых, обезуглероживание электроэнергии как ключевое изменение, которое означает массовый рост ветровой и солнечной энергии для выработки безуглеродной электроэнергии, на которой будут работать все остальные сектора экономики - транспорт, жилищно-коммунальное хозяйство и т. д. Во-вторых, по первоначальным подсчетам, около 2/3 потребляемой сегодня углеводородной энергии может быть переведено на «электрическую тягу». Оставшаяся треть энергопотребления в общем энергетическом балансе, там, где трудно или невозможно использовать электричество (например, авиаперелеты) может быть замещена водородом вместе с другими биоэнергетическими источниками. Водород может производиться в промышленных масштабах с помощью энергии ветра или солнца («зеленый водород») или путем паровой конверсии природного газа (метана) («синий водород»), что, вероятно, будет иметь решающее значение для обезуглероживания нефтегазового сектора.

Формирование низкоуглеродной экономики, сопровождающееся кардинальным изменением структуры глобального энергетического баланса путем замещения ископаемых углеродных источников энергии (уголь, нефть, газ) возобновляемыми (солнце, ветер, гидро- и биоэнергия), - так называемый «энергетический переход», по оценкам экспертов [6], потребует многосекторальных изменений и совместной работы всего общества для достижения поставленных целей. Очевидно, что природный газ жизненно важен для достижения чистого нулевого углеродного будущего. Доля газа в первичной энергии продолжает расти из года в год, достигнув рекордного уровня почти в $25 \%$ в 2020 году. Во многих частях Азии экономика по-прежнему сильно зависит от угля для производства электроэнергии. По мере того как рост благосостояния поднимает людей с низких доходов до средних, повышается спрос на энергию. Часть этого спроса может быть удовлетворена за счет роста солнечной энергии и ветра, но этого недостаточно, чтобы удовлетворить новый спрос на энергию и заменить существующие уровни энергии угля. Поэтому природный газ играет существенную роль в том, чтобы помочь достаточно быстро декарбонизировать энергетические сектора в течение последующего десятилетия.

Наряду с этим, в текущих условиях технологического развития ключевым барьером расширения использования возобновляемой энергетики является нестабильность выработки энергии возобновляемыми источниками энергии (ВИЭ), связанная с изменчивостью погодных условий. Технологическим решением служат накопители энергии, которые позволят компенсировать ее нехватку в пиковые часы потребления, во время штиля или при отсутствии солнца. Однако пока эффективных решений промышленного уровня недостаточно. Кроме того, нет эффективных технологий утилизации отработавших свой срок солнечных станций и ветрогенераторов, а также акуммуляторных батарей.

Климатическая повестка преобразует общеэкологические вопросы в вопросы климатической безопасности как на международном уровне, так и на национальном. Климатическая безопасность как относительно новый вызов для населения планеты рассматривается в качестве приоритета, а стимулирование развития правовой базы «зелёной» экономики, по мнению специалистов [7, с. 8], требует принятия соответствующей кониепиии правового обеспечения «зеленой» экономики, включающей принципы правового регулирования и понятийный аппарат с учетом положений современной доктрины и актов международного права.

Проблемы климатического права, возможности международно-правового и национального регулирования в сфере климата и экологии, адаптация права под влиянием климатических изменений и перспектив углеродного регулирования широко обсуждаются в научном мире [8, с. 21-33].

Актуальность вопроса климатической («зелёной») повестки для международного сообщества после Парижского соглашения по климату (2015 г.) подтверждается созывом 26 Конференции сторон Рамочной конвенции ООН об изменении климата (СОР26) в ноябре 2021 года в Глазго, а в национальном плане - разработкой документа о планировании и реализации мер по адаптации экономики Российской Федерации к глобальному энергопереходу и внесении дополнений в Единый план достижения национальных целей развития Российской Федерации до 2030 года ${ }^{6}$. Основная цель СОР26 состоит в согласовании всеми странами участницами Правил реализации Парижского соглашения и, прежде всего, в части рыночных и внерыночных механизмов, порядка предоставления отчетности по выполнению условий Соглашения, а также создание специального адаптационного фонда финансирования для развивающихся государств. Для Российской Федерации «зелёная повестка» охватывает всю сферу природоохранных мероприятий на всей территории страны от обеспечения экологической безопасности в Арктике до борьбы с опустыниванием на юге страны, включая признание роли лесов и лесных проектов, а также атомной энергии как реального инструмента борьбы с изменением климата.

\footnotetext{
Поручение Правительства РФ от 20.09.2021 «О решениях по итогам стратегической сессии «Адаптация России к глобальному энергопереходу» // СПС «КонсультантПлюс». URL: http://www.consultant.ru
} 
Россия уже вносит существенный вклад в снижение выбросов и иных негативных влияний парниковых газов.

Большое значение в сфере законодательства о климате имеют акты международного права: Рамочная конвенция ООН об изменении климата (Нью-Йорк, 1992 г.) с последующими протоколами и приложениями, Конвенция о биологическом разнообразии (1992 г.) и др. Национальное законодательство многих стран пополняется новыми законами и подзаконными актами по климатической проблематике.

Непосредственная адаптация Российской Федерации к глобальному энергопереходу в соответствии с Постановлением Правительства РФ от 30.12.2009 №1166 (в ред. от 15.10.2021) «О Правительственной комиссии по экономическому развитию и интеграции» предполагает решение ряда задач, включая определение приоритетных направлений деятельности в сфере минимизации рисков и использования возможностей, связанных с глобальным энергопереходом, разработку сценарного прогноза долгосрочного развития и планов адаптации и мониторинга показателей к низкоуглеродной экономике Российской Федерации, а также нормативно-правовое регулирование компенсационных мер и финансовых средств между субъектами Российской Федерации и отраслями экономики для минимизации последствий от глобального энергоперехода ${ }^{7}$.

Для достижения целей Парижского соглашения по климату, как отмечается в Концепции развития водородной энергетики в Российской Федерации, Россия осуществляет государственную политику в области климата, направленную на сокращение и предотвращение антропогенных выбросов парниковых газов, в том числе за счет расширения сфер применения энергоносителей с низким углеродным следом и внедрения наилучших доступных технологий.

Так, Указом Президента РФ от 04.11.2020 № 666 «О сокращении выбросов парниковых газов» ${ }^{8}$ поставлена стратегическая задача обеспечить к 2030 году сокращение выбросов парниковых газов до 70\% уровня 1990 года, разработать Стратегию социально-экономического развития Российской Федерации с низким уровнем выбросов парниковых газов до 2050 года и утвердить ее, а также обеспечить создание условий для реализации мер по сокращению и предотвращению выбросов парниковых газов и по увеличению поглощения таких газов.

Во исполнение обязательств России в рамках Парижского соглашения по климату и приведенного выше Указа Президента РФ принят Федеральный закон от 02.07.2021 № 296-Ф3 «Об ограничении выбросов парниковых газов» ${ }^{9}$, который вступает в силу с 1 января 2022 года и направлен на создание условий для устойчивого и сбалансированного развития экономики России при снижении уровня выбросов парниковых газов.

Европейская Комиссия в декабре 2019 года опубликовала Европейскую зелёную стратегию (European Green

Собрание законодательства Российской Федерации. 2010. № 3. Ст. 303.

8 Собрание законодательства Российской Федерации. 2020. № 45. Ст. 7095

9 Собрание законодательства Российской Федерации. 2021. № 27 (часть I). Ст. 5124.
Deal), главной целью которой стало достижение 100\% климатической нейтральности (нулевых нетто-выбросов всех парниковых газов (ПГ), где объем выбросов ПГ равен объему улавливания и поглощения ПГ) государствами ЕС к 2050 году. Уже в июне 2021 года Европейский Парламент ратифицировал Европейский закон о климате (European Climate Law), который стал правовой основной европейского климатического законодательства с амбициозной целью создания климатически нейтральной Европы к 2050 году. Закон устанавливает юридически обязывающие требования по достижению целевых показателей по сокращению выбросов парниковых газов в 2030 год на уровне 55\% по сравнению с 1990 годом вместо ранее применявшегося целевого показателя в 40\%.

По оценке Bloomberg New Energy Finance (BNEF), общий уровень инвестиций в энергетический переход составил рекордные 501,3 млрд долларов США. Среди всех стран мира наибольший прирост приходится именно на Европейский Союз: +67\% к 2019 году. В Китае и США наблюдается сокращение финансирования энергетического перехода на $12 \%$ и $11 \%$ к 2019 году соответственно. Наибольший уровень инвестиций пришелся на сектор возобновляемой энергетики - 303,5 млрд долларов США [9]. Согласно докладу Международного энергетического агентства (МЭА) в 2021 г. «Net Zero by 2050», для достижения целей углеродной нейтральности суммарный ввод ветровых (ВЭС) и солнечных электростанций (СЭС) к 2030 году должен составить около 1000 ГВт, что эквивалентно ежедневной установке крупнейшего в мире солнечного парка. К 2050 году на крышах домов должно быть установлено около 240 млн солнечных панелей. Для сравнения: в 2020 году количество таких объектов микрогенерации в домохозяйствах насчитывало порядка 25 млн [10, с. 12].

В силу экологических и гуманитарных причин, о которых говорилось выше, энергетический переход не может быть проигнорирован, пока возобновляемая энергетика не сможет в полном объеме обеспечивать растущие потребности населения Земли. По крайней мере до тех пор традиционная энергетика продолжит занимать доминирующее положение в мировой экономике, обеспечивая бесперебойное снабжение людей доступными и надежными энергоресурсами.

Расширяющееся распространение новых технологий использования альтернативных ВИЭ в противовес традиционным (углеводородным), трансформация экономической политики ЕС и введение так называемого углеродного налога создают дополнительные риски для компаний топливно-энергетического комплекса (ТЭК), стимулируют их к внедрению низкоуглеродных технологий и снижению выбросов парниковых газов, разработке технологий на основе новых источников энергии (водород и др.). Многие страны реализуют крупномасштабные программы расходов для достижения целей низкоуглеродной экономики, включая ЕС, США, Китай, Японию и другие страны с амбициозными планами экономического стимулирования, и нефинансовых мер повышения эффективности бизнеса на основе критериев ESG («экологическое, социальное, корпоративное управление»). В результате в ТЭК вопрос адаптации к происходящим изменениям становится как никогда актуальным. Эта адаптация включает в себя как раз- 
витие микрогенерации, так и переход компаний на модели устойчивого развития. Управленческая модель ESG предлагает разблокировать значительное положительное влияние для инвесторов, компаний и общества в целом. Экосистема ESG и связанная с ней инвестиционная практика включают в себя расширенные возможности управления рисками, повышение вовлеченности сотрудников и возможность использовать новые возможности роста и выгоды, которые часто приводят к улучшению долгосрочных финансовых показателей.

Для достижения наилучшего результата глобальная экономика и экономика каждой страны, от нефтегазовых отраслей до ИКТ, должна быть преобразована, поскольку существует потребность в создании совершенно новых основ для современных экономических и социальных систем - «Великая перезагрузка», по Клаусу Швабу [11]. Это означает создание условий для «экономики заинтересованных сторон», продвижение инвестиций на основе равенства и устойчивости, строитель- ство «зеленой» городской инфраструктуры и создание стимулов для соответствия отраслей показателям ESG. Такое преобразование должно быть оформлено надлежащим образом с точки зрения структурированных правовых актов, системности правового регулирования.

\section{Выводы}

Создание нового направления правового регулирования - климатического права - формирует новый вектор конкурентных отношений с участием государств, частных корпораций и других участников глобального перехода от традиционной энергетики к энергетике ВИЭ. Расширение и структурирование правовой базы регулирования вопросов климатической повестки закономерно приводит к формированию климатического права, перспективы которого во многом будут определяться активностью деятельности государств и частных компаний в национальном и международном масштабе.

\section{Литература}

1. AN OECD Horizon Scan of Megatrends and Technology. Trends in the Context of Future Research Policy. A. Barreneche, S. Fraccola et al., OECD, 2016. URL: http://ufm.dk/en/publications/2016/an-oecd-horizon-scan-of-megatrends-and-technology-trends-in-the-context-of-future-researchpolicy

2. Emissions Database for Global Atmospheric Research, European Commission, 2021. URL: http://edgar.jrc.ec.europa.eu/report_2020

3. Global Compact Network Russia. URL: http://globalcompact.ru/about/sdgs

4. Организация Объединенных Наций. URL: http://www.un.org/ru/36167

5. ВЭБ РФ. URL: http://вэб.pф/o-banke/mezhdunarodnoye-sotrudnichestvo/uchastie-v-globalnom-dogovore-oon

6. Climate Finance Provided and Mobilised by Developed Countries: Aggregate trends updated with 2019 data, Climate Finance and the USD 100 Billion Goal. OECD (2021), OECD Publishing, Paris. URL: http://doi.org/10.1787/03590fb7-en

7. Новикова Е.В. Концептуальные основы правового регулирования «зеленой» экономики в России // Экологическое право. 2020 . № 5. C. 3-10. DOI: $10.18572 / 1812-3775-2020-5-3-10$.

8. Право и климат планеты: научное издание / колл. авторов; отв. ред. Ю.А. Тихомиров, С.А. Боголюбов, Н.В. Кичигин. М. : Юстиция, 2020. $174 \mathrm{c}$.

9. Bloomberg: The Global Energy System Is Like a Troubled Tween. URL: http://www.bloomberg.com/opinion/articles/2021-10-13/iea-world-energyoutlook-2021-throw-money-but-aim-carefully

10. Кулапин А. Энергетический переход: Россия в глобальной повестке // Энергетическая политика. 2021. № 7(161). С. 10-15.

11. Klaus Schwab, Thierry Malleret. COVID-19: The Great Reset. 2019. URL: http://digital-economy.ru/mneniya/the-great-reset-klausa-shvaba-i-terrimallereta-kak-novyj-manifest-ultraglobalistov

\section{LAWS ON CLIMATE UNDER THE CONDITIONS OF ENERGY TRANSITION TO LOW-CARBON ECONOMY}

A. Kartskhiia ${ }^{10}$

Keywords: climate agenda, climate law, corporate governance, energy law, green energy.

Abstract.

Purpose of the work: analysing modern international treaties (conventions) and domestic laws in the field of energy and climate changes with a view to identify the patterns of formation and features of this sphere of legal regulation.

Method of study: using system analysis of the current laws and legal doctrines in combination with comparative legal analysis of the sphere of legal regulation under study including Russian and foreign legislation as well as instruments of international law.

Results of study: the author came to the conclusion that under the influence of global megatrends related to changes in the world around us, transformation of the economy and technological development under the conditions of

10 Aleksandr Kartskhiia, Dr.Sc. (Law), Professor at Gubkin Russian State University of Oil and Gas (National Research University), Moscow, Russian Federation. E-mail: arhz50@mail.ru 
combating the global pandemic, the climate agenda came to the forefront in international relations and is accompanied by active law-making in many countries of the world. National strategies and new tendencies in management models stimulate implementing low-carbon technologies and reducing the emission of greenhouse gases as well as developing technologies based on renewable energy sources. A system of international legal instruments and domestic laws in the field of global protection of the planet's climate and regulating the negative impact of anthropogenic factors in the activities of countries and corporations is being created. A new area of legal regulation, the climate law, is created which, in the author's opinion, forms a new vector of competitive relations with the participation of countries, private corporations and other participants in the global transition from traditional energy to energy from renewable sources.

\section{References}

1. AN OECD Horizon Scan of Megatrends and Technology. Trends in the Context of Future Research Policy. A. Barreneche, S. Fraccola et al., OECD, 2016. URL: http://ufm.dk/en/publications/2016/an-oecd-horizon-scan-of-megatrends-and-technology-trends-in-thecontext-of-future-research-policy

2. Emissions Database for Global Atmospheric Research, European Commission, 2021. URL: http://edgar.jrc.ec.europa.eu/report_2020

3. Global Compact Network Russia. URL: http://globalcompact.ru/about/sdgs

4. Organizatsiia Ob”edinennykh Natsii. URL: http://www.un.org/ru/36167

5. VEB RF. URL: http://veb.rf/o-banke/mezhdunarodnoye-sotrudnichestvo/uchastie-v-globalnom-dogovore-oon

6. Climate Finance Provided and Mobilised by Developed Countries: Aggregate trends updated with 2019 data, Climate Finance and the USD 100 Billion Goal. OECD (2021), OECD Publishing, Paris. URL: http://doi.org/10.1787/03590fb7-en

7. Novikova E.V. Kontseptual'nye osnovy pravovogo regulirovaniia "zelenoi" ekonomiki v Rossii. Ekologicheskoe pravo, 2020, No. 5, pp. 3-10. DOI: 10.18572/1812-3775-2020-5-3-10 .

8. Pravo i klimat planety: nauchnoe izdanie. Koll. avtorov; otv. red. Iu.A. Tikhomirov, S.A. Bogoliubov, N.V. Kichigin. M. : Iustitsiia, 2020. $174 \mathrm{~s}$.

9. Bloomberg: The Global Energy System Is Like a Troubled Tween. URL: http://www.bloomberg.com/opinion/articles/2021-10-13/ iea-world-energy-outlook-2021-throw-money-but-aim-carefully

10. Kulapin A. Energeticheskii perekhod: Rossiia v global'noi povestke. Energeticheskaia politika, 2021, No. 7(161), pp. 10-15.

11. Klaus Schwab, Thierry Malleret. COVID-19: The Great Reset. 2019. URL: http://digital-economy.ru/mneniya/the-great-reset-klausashvaba-i-terri-mallereta-kak-novyj-manifest-ultraglobalistov

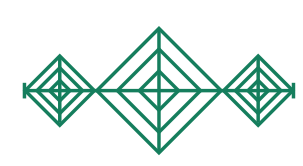




\title{
ОРГАНИЗАЦИЯ ПРАВОВОГО ПРОСвЕЩЕНИЯ В СУБЪЕКТАХ РОсСИЙСКОЙ ФЕдЕРАЦИИ
}

\begin{abstract}
Кабанов П. А."
Ключевые слова: мониторинг, регулирование, просвещение, субъекты просвещения, органы юстиции, субъекты Российской Федерации.

Аннотация.

Цель: исследование основных вопросов правового регулирования организации и осуществления правового просвещения в субъектах Российской Федерации.

Метод исследования: компаративный анализ действующего законодательства и правовых доктрин в сочетании со сравнительно-правовым анализом рассматриваемой области правового регулирования.

Результат: оценены региональные правовые акты, регулирующие организацию правового просвещения, выявлены основные субъекты организации и осуществления правового просвещения в регионах, дана классификация видов правового просвещения. Выявлены основные недостатки правового регулирования правового просвещения в субъектах Российской Федерации и предложены меры по их устранению. Организация и осуществление правового просвещения в субъектах Российской Федерации регулируются множеством нормативных правовых актов разной юридической силы, посвященным различным сторонам правового регулирования деятельности органов публичной власти: специальных нормативных актов, посвященных исключительно организации и осуществлению правового просвещения, недостаточно. Рекомендуется субъектам Российской Федерации шире применять практику принятия специальных законов, регулирующих вопросы правового просвещения, а также региональных программ (планов) по реализации этого законодательства. Контроль за исполнением законодательства о правовом просвещении следует возложить на региональные органы юстиции или иные органы, наделив их полномочиями по мониторингу организации и осуществлению правового просвещения.
\end{abstract}

DOI: 10.21681/2226-0692-2021-4-56-67

\section{Введение}

$\mathrm{B}$ сударства и гражданского общества, повышения правосознания, правовой культуры и правовой грамотности в обществе, а также снижения в нем правового нигилизма выступает правовое просвещение. Вопросам правового просвещения в современной России посвящено значительное количество нормативных правовых актов, проведены многочисленные научные исследования, опубликовано множество научных, учебных и методических произведений, в которых раскрывается его содержание и методы осуществления.

Правовое просвещение как надежный инструмент распространения правовых знаний закреплено в федеральном законодательстве. Оно предусмотрено законодателем, во-первых, в качестве функции федерального органа исполнительной власти ${ }^{1}$, а во-вторых, в качестве средства воздействия при осуществлении профилактики правонарушений${ }^{2}$. В-третьих, правовое просвещение является одной из основных функций уполномоченного по правам человека субъектов Российской Федерации 3 . B-четвертых, правовое просвещение закреплено в каче- стве подфункции органа государственной власти - содействие в его осуществлении ${ }^{4}$. В-пятых, осуществление функций по правовому просвещению является одним из вариантов одобряемого законом и стимулируемого государством направления деятельности некоммерческих $^{5}$ и волонтерских ${ }^{6}$ организаций. На федеральном уровне организация и правовое регулирование вопросов правового просвещения закреплены за Министерством юстиции Российской Федерации ${ }^{7}$. Отдельные полномочия по осуществлению правового просвещения предусмотрены в правовых актах по организации деятельности иных органов государственной власти. Наиболее полно и качественно вопросы организации и осуществления правового просвещения закреплены в нормативных актах органов прокуратуры Российской Федерации ${ }^{8}$.

Созданная система организации и функционирования правового просвещения на федеральном уровне не может работать эффективно, если в реализации основных положений не будут системно, последовательно и эффективно приниматься меры на региональном уровне.

Кабанов Павел Александрович, доктор юридических наук, доцент, директор НИИ противодействия коррупции Казанского инновационного университета имени В. Г. Тимирясова (ИЭУП), г. Казань, Российская Федерация. E-mail: kabanovp@mail.ru 
Вопросы правового мониторинга в Российской Федерации последовательно исследовались отечественными специалистами. Достаточно полно и всесторонне рассмотрены общетеоретические вопросы: понятие, содержание и значение правового мониторинга [2, с. 2-7; 17 , с. 25-29; 25, с. 189-192; 27, с. 11-13], а также организации его проведения $[3 ; 8 ; 11 ; 16 ; 23 ; 26 ; 29 ; 32$, с. 59-64]. В меньшей степени отечественными специалистами исследованы вопросы правового просвещения как самостоятельного института правовой политики государства; имеющиеся публикации по данной проблематике достаточно полно раскрывают его содержание и предназначение $[1$, с. $107-111 ; 6$, с. $113-118 ; 13$, с. $49-52 ; 14$, с. $179-$ $188 ; 30$, с. $36-44 ; 31$, с. 85-89], в том числе и на региональном уровне [11, с. $30-32 ; 24$, с. $31-33 ; 33$, с. $6-8]$.

Следует отметить, что отдельные попытки мониторинга правового просвещения в субъектах Российской Федерации осуществлялись отечественными специалистами, но они касались некоторых вопросов его организации и проведения [4, с. 66-70] либо обеспечения его в определенных сферах жизнедеятельности, в частности, образования [7, с. $147-154 ; 19$, с. 108-115]. Это свидетельствует о необходимости проведения специального мониторинга - мониторинга правового регулирования вопросов организации и осуществления правового просвещения на региональном уровне.

Объект исследования - общественные отношения по организации и реализации института правового просвещения.

Предмет исследования - специфика правового регулирования организации и реализации института правового просвещения в различных субъектах Российской Федерации.

Цель исследования - оценка состояния правового регулирования организации правового просвещения в субъектах Российской Федерации и выработка предложений по его совершенствованию.

Задачи исследования:

> поиск, фиксация, оценка нормативных правовых актов субъектов Российской Федерации по организации правового просвещения;

> выявление недостатков правового регулирования организации правового просвещения в субъектах Российской Федерации;

> разработка предложений по совершенствованию правового регулирования организации правового просвещения в субъектах Российской Федерации.

Методологической основой проведенного исследования является диалектический материализм и основанные на нем общенаучные методы исследования: анализ, синтез, сравнение, экстраполяция и другие, применяемые в юридических науках.

Эмпирическая база проведенного исследования включает в себя 332 региональных закона и 389 подзаконных нормативных актов субъектов Российской Федерации.

Территориальные и хронологические рамки исследования: вся территория Российской Федерации, включая город федерального значения Севастополь и Республику Крым с момента их вхождения в состав Российской Федерации, в период с 1 января 2000 года по 1 ноября 2021 года.

\section{Процесс и результаты проведенного исследования}

Правовое просвещение на региональном уровне, так же как и на федеральном, является одним из основных средств повышения правосознания и правовой культуры в обществе, а также средством профилактического воздействия на неправомерное (преступное) поведение. Функции правового просвещения в субъектах Российской Федерации закрепляются различными по юридической силе нормативными актами. В одних случаях они устанавливаются нормами конституционного (уставного) законодательства, в других - региональными законами, в третьих - подзаконными нормативными актами. Например, статьей 36 Устава Архангельской области правовое просвещение населения возложено на Уполномоченного по защите прав человека этой области ${ }^{9}$. Статьей 2 Уставного закона Калининградской области «Об Уполномоченном по правам человека в Калининградской области» на Уполномоченного по защите прав человека этой области также возложены полномочия по осуществлению правового просвещения $^{10}$. Аналогичным образом возложены полномочия по осуществлению правового просвещения на Уполномоченного по правам человека Красноярского края ${ }^{11}$. Конституционными законами по организации деятельности уполномоченных по правам человека в субъекте Российской Федерации закреплены полномочия по правовому просвещению населения на указанных должностных лиц в Чеченской Республике ${ }^{12}$ и Республике Тыва ${ }^{13}$. Региональным законодательством субъектов Российской Федерации полномочия по организации и осуществлению правового просвещения возлагаются на различные субъекты общей и специальной компетенции, которые они должны осуществлять в пределах делегированных им полномочий. При этом организация и осуществление правового просвещения предусматривается в отношении отдельных категорий населения. В связи с этим можно выделить несколько направлений правового просвещения: общее правовое просвещение, осуществляемое в отношении всего населения региона; специальное правовое просвещение, осуществляемое компетентными на то органами в отношении определенной категории лиц этого региона. Общее правовое просвещение регулируется специальным региональным законодательством о правовом просвещении. В настоящее время лишь в нескольких субъектах Российской Федерации имеются специальные законы об организации и осуществлении правового просвещения. Такие региональные законы приняты и реализуются во Владимирской $^{14}$, Воронежской ${ }^{15}$, Курганской ${ }^{16}$, Ленинградской ${ }^{17}$, Самарской ${ }^{18}$ и Тверской ${ }^{19}$ областях. В рамках реализации Закона Томской области «О просветительской деятельности в Томской области» в этом субъекте Российской Федерации предусмотрено осуществление правового просвещения органами государственной власти и иными субъектами просветительской деятельности ${ }^{20}$. Длительное время особую значимость правовому просвещению придавало специальное региональное законодательство о среднесрочном планировании (программировании) организации этого инструмента формирования правовой культуры и правосознания в регионе $\mathrm{e}^{21}$. 
Однако в настоящее время программирование правового просвещения используется в ином правовом статусе, утверждаемое не законами, а подзаконными нормативными актами ${ }^{22}$.

В отдельных субъектах Российской Федерации региональным законодательством вопросы организации общего правового просвещения возлагаются на высшие органы исполнительной власти субъекта Российской Федерации. Например, законодательством городов федерального значения Москва и Севастополь об организации деятельности правительства организация мероприятий по правовому просвещению жителей города возложена на правительство этих городов ${ }^{23}$. Такими же полномочиями по организации и осуществлению правового просвещения региональным законодательством наделены правительства Алтайского ${ }^{24}$, Забайкальского ${ }^{25}$ и Пермского ${ }^{26}$ краев, а также Чукотского автономного округа ${ }^{27}$.

Организация и осуществление специального правового просвещения возлагаются региональным законодательством на отдельные региональные государственные структуры для воздействия на определенные этим законодательством целевые группы либо в определенной сфере жизнедеятельности. Рассмотрим подробнее эти специальные виды правового просвещения, выделенные по субъектам его осуществления.

В 79 субъектах Российской Федерации региональным законодательством об уполномоченных по правам человека за ними закреплены полномочия по проведению и/или содействию в проведении специального правового просвещения в сфере обеспечении прав и свобод человека и гражданина, борм и методов их защить. На эту функцию уполномоченных по правам человека указывают не только современные российские исследователи [21, с. $13-29 ; 22$, с. $131-138 ; 28$, с. 246-251], но и сами региональные уполномоченные по правам человека $[20$, с. $310-318]$.

В 47 субъектах Российской Федерации региональным законодательством об уполномоченных по защите прав предпринимателей предусмотрены полномочия указанных лиц по организации и осуществлению ими специального правового просвещения предпринимателей (субъектов предпринимательской деятельности) по вопросам принадлежащих им прав и законных интересов, форм и способов их зашиты.

В 41 субъекте Российской Федерации региональным законодательством об уполномоченных по правам ребенка за ними закреплено специальное правовое просвещение населения по вопросам реализации прав и законных интересов детей, а также форм и методов их защитьиь.

Наиболее значимым региональным законодательством по вопросам осуществления специального правового просвещения населения выступает законодательство субъектов Российской Федерации об оказании бесплатной юридической помощи. Оно принято во всех субъектах Российской Федерации, а в некоторых регионах действуют даже одновременно по два (Республика Коми, Республика Крым, Алтайский, Забайкальский и Хабаровский края, Вологодская, Новгородская, Самарская и Тульская области) и три (Владимирская и Сахалинская области) закона о предоставлении бесплатной юридической помощи, регулирующих различные аспекты её обеспечения. В то же время из 98 действующих региональных законов об оказании юридической помощи только в 55 (56,1\%) упоминается об осуществлении уполномоченными на то органами, организациями и лицами правового просвещения граждан, имеющих право на получение бесплатной юридической помощи в рамках государственной системы бесплатной юридической помощи.

Общее региональное криминологическое законодательство, регулирующее общие вопросы профилактики правонарушений и преступлений, а также специальное криминологическое законодательство, регулирующее деятельность по профилактике отдельных видов правонарушений (экстремизма ${ }^{28}$, коррупции, наркотизма) или в отношении отдельных категорий правонарушителей (несовершеннолетних, ранее судимых, наркозависимых) предполагает использование специального правового просвещения в качестве средств профилактического воздействия. При этом специальное правовое просвещ,ение в рамках криминологического законодательства имеет целевую направленность на обеспечение защиты прав и свобод человека и гражданина, общества и государства от противоправных посягательств и распространяется исключительно на сферу профилактики правонарушений. Оно может быть направлено на определенные категории населения:

> лиц, отбывших уголовное наказание в виде лишения свободы ${ }^{29}$;

> несовершеннолетних, совершивших правонарушения ${ }^{30}$;

> несовершеннолетних и молодежь ${ }^{31}$;

> руководителей координирующих органов (штабов) народных дружин ${ }^{32}$;

> участников образовательного процесса, включая педагогических работников ${ }^{33}$;

> лиц, подвергшихся насилию в семье ${ }^{34}$.

В отдельных субъектах Российской Федерации криминологическим законодательством предусмотрено осуществление правового просвещения без указания его отраслевой принадлежности (специфики) $)^{35}$, именуя его «всеобщим правовым просвещением населения» ${ }^{36}$, то есть не только в сфере профилактики правонарушений, но и в иных сферах. Например, в сфере защиты прав ребенка ${ }^{37}$; в сфере прав и обязанностей несовершеннолетних, их родителей или иных законных представителей ${ }^{38}$; по вопросам защиты прав и свобод человека и гражданина, обеспечения законности, общественной нравственности, общественного порядка и общественной безопасности, а также по вопросам административного законодательства ${ }^{39}$; в сфере противодействия коррупции ${ }^{40}$; в сфере защиты прав потребителей ${ }^{41}$.

Фактически такое правовое просвещение, связанное с обеспечением безопасности физических и юридических лиц от правонарушений, следует именовать криминологическим просвещением [5, с. 4-6; 18, с. 34-36], а отдельные его виды, связанные с реализацией иного законодательства - видовым криминологическим правовым просвещением (антикриминальным, антитеррористическим, антинаркотическим, антикоррупционным и т. д.). Видовое криминологическое правовое просвещение закрепляется в региональном законодательстве и некоторых 
региональных нормативных правовых актах. Сегодня такие формы видового криминологического правового просвещения уже успешно исследуются отечественными специалистами [9, с. 270-279; 10, с. 63-67; 15, с. 131-135].

В региональном законодательстве о выборах и деятельности избирательных комиссий в субъектах Российской Федерации предусмотрен особый вид специального правового просвещения - правовое просвещение избирателей ${ }^{42}$ и/или иных участников выборов ${ }^{43}$ либо населения по вопросам избирательного права ${ }^{44}$.

Особой разновидностью регионального законодательства, регулирующего вопросы правового просвещения, следует признать законодательство субъектов Российской Федерации о деятельности некоммерческих, благотворительных (волонтерских $)^{45}$ и иных общественных организаций ${ }^{46}$, которым предусмотрено осуществление ими правового просвещения, а также законодательство о государственном стимулировании деятельности некоммерческих организаций, осуществляющих правовое просвещение ${ }^{47}$, либо о взаимодействии с ними региональных органов государственной власти ${ }^{48}$.

Особым видом спещиального правового просвещения, предусмотренного действующим законодательством Новгородской области о миграционной политике, является правовое просвещение по вопросам реализации региональной миграционной политики отдельной целевой группь - мигрантов ${ }^{49}$. Подзаконными нормативными актами других субъектов Российской Федерации, связанными с реализацией миграционной политики, также предусмотрено правовое просвещение мигрантов ${ }^{50}$. Это положение регионального законодательства было заимствовано из ранее действовавшей Концепции государственной миграционной политики Российской Федерации на период до 2025 года, утратившей свою силу еще в 2018 году ${ }^{51}$.

Несколько необычным выглядит специальное правовое просвещение в Республике Татарстан, которое подразумевает правовое просвещение определенной категории населения этого региона - потерпевших от неисполненных гражданско-правовых договоров «обманутых дольщиков" по вопросам защить их жилищных $\boldsymbol{n р a в}^{52}$. О правовом просвещении пострадавших участников долевого строительства говорится и в региональном законодательстве Архангельской области, регулирующем вопросы социального строительства ${ }^{53}$. Такое специальное правовое просвещение, с учетом специфики контингента просветительского воздействия - жертв правонарушений и преступлений в сфере социального строительства, - следует именовать виктимологическим просвещением.

Современным российским региональным законодательством возлагается на органы исполнительной власти субъектов Российской Федерации исполнение функций правового просвещения при реализации ими молодежной политики, направленного на правовое просвещение определенной возрастной социальной группы - молодежи ${ }^{54}$.

Законодательством города федерального значения Москвы, регулирующим трудовые отношения, предусмотрено специальное видовое правовое просвещение правовое просвещение работодателей, работников и других лиц в области охраны труда ${ }^{55}$.
Подзаконными нормативными правовыми актами высшего органа исполнительной власти Забайкальского края в региональной целевой программе об общественном здоровье предусмотрено правовое просвещение по вопросам брака и семьи ${ }^{56}$.

Возложение региональными законодателями дополнительных функций на отдельные государственные органы специальной компетенции привело к тому, что на Аппарат Уставного суда Свердловской области была возложена обязанность по осуществлению правового просвещения граждан ${ }^{57}$. Данная функция отсутствует в полномочиях аналогичных обеспечительных органов системы правосудия в других субъектах Российской Федерации. Законом Республики Бурятия «О некоторых вопросах деятельности нотариата на территории Республики Бурятия» дополнительная обязанность по правовому просвещению и правовому информированию населения была возложена на нотариусов ${ }^{58}$. Законом Брянской области «О содействии деятельности казачьих обществ и общественных объединений казаков на территории Брянской области» предусмотрено участие в правовом просвещении казачьих обществ и общественных объединений казаков ${ }^{59}$.

Особенностью правового регулирования организации правового просвещения вне рамок специального регионального законодательства о правовом просвещении является то, что содержание этой правовой категории в нем не раскрывается. Вопросы организации и осуществления рассматриваются фрагментарно, закрепляя функцию правового просвещения за отдельными органами, без указания показателей по оценке эффективности его применения. Специальное региональное законодательство о правовом просвещении достаточно полно определяет базовые категории «правовое просвещение», «субъекты правового просвещения», «система правового просвещения», основные принципы, цели и задачи правового просвещения, полномочия субъектов правового просвещения, средства правового просвещения, особенности взаимодействия субъектов правового просвещения. Хотя это законодательство ещё находится в стадии становления и не свободно от технических и смысловых противоречий, однако оно позволяет закрепить систему организации и осуществления правового просвещения, разграничить компетенцию между региональными органами власти, создать правовые основы ее жизнеспособности, а в последующем и эффективности.

Мониторинг правового регулирования вопросов организации и осуществления правового просвещение в субъектах Российской Федерации оказался бы неполным, если бы мы не обратились к подзаконным нормативным правовым актам.

Группу подзаконных нормативных актов субъектов Российской Федерации следует классифицировать на несколько самостоятельных видов по различным критериям. Во-первых, это нормативные акты, устанавливающие полномочия органов публичной власти либо органов специальной компетенции по организации, планированию и осуществлению правового просвещения в субъекте Российской Федерации ${ }^{60}$. Во-вторых, нормативные правовые акты, определяющие организационно-правовые механизмы (планирование и программирование) осуществления правового просвеще- 
ния $^{61}$. В-третьих, нормативные акты, устанавливающие порядок и/или методику применения средств правового просвещения ${ }^{62}$. В-пятых, нормативные правовые акты, регулирующие вопросы взаимодействия между различными субъектами правового просвещения ${ }^{63}$. В-шестых, нормативные правовые акты, регулирующие деятельность региональных органов юстиции, с наделением их функцией по осуществлению мониторинга правового просвещения в субъекте Российской Федерации ${ }^{64}$. В-седьмых, нормативные правовые акты, регулирующие наделение полномочиями органов публичной власти по осуществлению правового просвещения ${ }^{65}$.

\section{Выводы по результатам проведенного исследования}

Проведенный нами анализ регионального законодательства по вопросам организации правового просвещения позволяет сделать некоторые выводы.

Во-первых, вопросы организации и осуществления правового просвещения в субъектах Российской Федерации регулируются нормативными актами различной отраслевой принадлежности: конституционными (уставными) нормами, в том числе нормами избирательного права; нормами криминологического права (нормами законодательства о профилактике правонарушений); нормами, регулирующими жилищные отношения; нормами административного права; нормами миграционного права; нормами, регулирующими реализацию молодежной политики, а также специальными нормативными актами по организации и осуществлению правового просвещения.
Во-вторых, организация и осуществление правового просвещения в субъектах Российской Федерации регулируется множеством нормативных правовых актов разной юридической силы, посвященных различным сторонам правового регулирования деятельности органов публичной власти - специальных нормативных актов, посвященных исключительно организации и осуществлению правового просвещения, недостаточно. Действующие региональные законы, регулирующие вопросы организации и осуществления правового просвещения, приняты и функционируют лишь в 6 субъектах Российской Федерации из 85. В некоторых субъектах Российской Федерации правовое регулирование организации и осуществления правового просвещения довольно полно регулируется региональными подзаконными актами, в том числе путем принятия специальных региональных документов стратегического планирования по организации правового просвещения (концепций, программ, планов).

В-третьих, субъектам Российской Федерации необходимо шире применять практику принятия специальных законов, регулирующих вопросы правового просвещения, а также региональных программ (планов) по реализации этого законодательства. Контроль за исполнением законодательства о правовом просвещении следует возложить на региональные органы юстиции или иные органы, наделив их полномочиями по мониторингу организации и осуществлению антикоррупционного просвещения.

\section{Литература}

1. Адаева О.В., Картыгин Н.С. Значение правового просвещения в правовоспитательном процессе как средства борьбы с правовым нигилизмом // Вопросы современной юриспруденции. 2016. № 6 (57). С. 107-111.

2. Алексеев А.Н. К вопросу о понятии и сущности правового мониторинга // Российская юстиция. 2011. № 10. С. 2 -7.

3. Андрианов А.Н., Болдырев В.Б., Бошно С.В., Бризицкий А.М. Правовой мониторинг : учебное пособие. М. : Юриспруденция, 2012. 415 с.

4. Андрианова Д.В. Мониторинг деятельности субъектов Российской Федерации в сфере правового просвещения в 2016 году // Мониторинг правоприменения. 2017. № 3(24). С. 66-70.

5. Астанин В.В. Концепция методического обеспечения криминологического просвещения родителей о преступности против несовершеннолетних // Мониторинг правоприменения. 2017. № 1(22). С. 4-6.

6. Божко А.С. Эволюция технологий института правового просвещения в России в XX - начале XXI вв. // Вестник Российского нового университета. Серия: Человек и общество. 2021. № 3. С. 113-118.

7. Болелова А.Г., Лекарева Е.Е. Правовое просвещение в системе образования: мониторинговое исследование // Образование личности. 2016. № 4. С. 147-154.

8. Варкова С.А. Мониторинг законодательства и правоприменительной практики (теоретико-правовое исследование): автореф. дис. ... канд. юрид. наук. М. : Российская академия народного хозяйства и государственной службы при Президенте РФ, 2013. $22 \mathrm{c}$.

9. Гармаев Ю.П., Попова Е.И. Организация антикриминального и антитеррористического просвещения в Крымском федеральном округе // Всероссийский криминологический журнал. 2016. Т. 10. № 2. С. 270-279.

10. Гармаев Ю.П., Чумакова Л.П. Концепция антикриминального просвещения в Российской Федерации и участие юридических вузов, студенческой молодежи в её реализации // Современная наука: актуальные проблемы теории и практики. Серия: Гуманитарные науки. 2018. № 12-2. С. 63-67.

11. Горохов Д.Б., Радченко В.И., Черногор Н.Н., Чеснокова М.Д. Правовой мониторинг: актуальные проблемы теории и практики : монография. Москва, 2010. 232 с.

12. Григорян К.Ю. Защита прав граждан в форме правового просвещения: опыт Республики Коми // Вестник. Государство и право. 2011. № 14. С. 30-32.

13. Долинина И.Г., Шакирова Е.А. Правовое просвещение: концептуальные основы // Высшее образование сегодня. 2013 . № 3. C. $49-52$. 
14. Доценко А.С. О понятии правового просвещения // Актуальные проблемы российского права. 2020. Т. 15. № 1 (110). C. $179-188$.

15. Зубенко Е.В., Бугаев Е.Н., Гармаева Д.А. О возможности развития правового (антикриминального) просвещения участников уголовного судопроизводства силами криминалистической науки // Закон и право. 2019. № 8. С. $131-135$.

16. Иванова Л.А. Определение эффективности нормативных правовых актов в процессе правового мониторинга: дис. ... канд. юрид. наук. М. : Московский новый юридический институт, 2011. 175 с.

17. Капицына Д.В. Правовой мониторинг (понятие, направления, субъекты, уровни) // Конституционное и муниципальное право. 2012. № 8. С. 25-29.

18. Лебедев С.Я. Криминологическое просвещение в системе правового воспитания населения // Криминологический журнал. 2003. № 1. C. $34-36$.

19. Лекарева Е.Е. Программно-методическое и информационное обеспечение правового просвещения в системе образования // Образование личности. 2017. № 3. С. 108-115.

20. Миков П.В. Правовое просвещение в деятельности Уполномоченного по правам человека в Пермском крае // Актуальные проблемы современного международного права. Материалы XVI Международного конгресса «Блищенковские чтения»: в 3 частях. М. : Российский университет дружбы народов, 2019. С. 310-318.

21. Миронов О.О. Правовое просвещение - функция омбудсменов // Право и образование. 2009. № 5. С. 13 -29.

22. Наренкова А.А., Яркина А.И. Совершенствование механизма правового просвещения уполномоченных по правам человека в субъектах Российской Федерации // Матрица научного познания. 2021. № 3-2. С. 131-138.

23. Невеселов А.А. Правовой мониторинг и государственная политика (теоретико-правовые основы взаимодействия): дис. ... канд. юрид. наук. Ростов-на-Дону : Ростовский юридический институт МВД Российской Федерации, 2009. 180 с.

24. Неустроева А.М. Правовое просвещение в Республике Саха (Якутия) // Актуальные проблемы реформирования современного законодательства: сборник статей Международной научно-практической конференции. Уфа: ООО «Аэтерна», 2017. C. $31-33$.

25. Омельченко Д.Э. Понятие и значение правового мониторинга // Новая наука: Опыт, традиции, инновации. 2016. № 10-2. С. $189-192$.

26. Правовой мониторинг: научно-практическое пособие / Андрианов А.Н., Болдырев В.Б., Бошно С.В. и др.; под ред. Ю. А. Тихомирова, Д. Б. Горохова. М. : Институт законодательства и сравнительного правоведения при Правительстве РФ, 2009.415 с.

27. Сологуб А.Ю. Правовой мониторинг: понятие и значение // Российская юстиция. 2015. № 8. С. 11-13.

28. Сучилина А.С., Хабарова М.А. Правовое просвещение граждан в рамках деятельности уполномоченного по правам человека // Ученые записки Тамбовского отделения РоСМУ. 2020. № 20. С. 246-251.

29. Фадеева А.С. Аналитическая функция правового мониторинга: дис. ... канд. юрид. наук. М. : Российский университет кооперации, 2011. 169 с.

30. Филиппова Н.А. Институционализация правового просвещения в Российской Федерации // Политическая экспертиза: ПОЛИТЭКС. 2019. Т. 15. № 1. С. 36-44.

31. Хиль И.М., Хорошенькова М.Ю. Правовое просвещение и правовое информирование как факторы формирования правового сознания молодежи // Очерки новейшей камералистики. 2021. № 1. С. 85-89.

32. Черепанова Е.В. Обеспечение планирования правового мониторинга // Журнал российского права. 2013. № 4 (196). С. 59 -64.

33. Шибалова Т.В., Золотарев Р.И. Правовое просвещение в Республике Марий Эл // Юридический мир. 2012. № 7. С. 6-8.

\section{Примечания}

1. Федеральный закон от 21.11.2011 № 324-Ф3 (в ред. от 01.07.2021 № 257-Ф3) «О бесплатной юридической помощи в Российской Федерации» // Собрание законодательства РФ. 2011. № 48. Ст. 6725.

2. Федеральный закон от 23.06.2016 № 182-Ф3 «Об основах системы профилактики правонарушений в Российской Федерации» // Собрание законодательства РФ. 2016. № 26 (Часть I). Ст. 3851.

3. Федеральный закон от 18.03.2020 № 48-Ф3 (в ред. от 30.04.2021 № 116-Ф3) «Об уполномоченных по правам человека в субъектах Российской Федерации» // Собрание законодательства РФ. 2020. № 12. Ст. 1640.

4. Федеральный конституционный закон от 26.02.1997 № 1-ФКЗ (ред. от 09.11.2020 № 6-ФКЗ) «Об Уполномоченном по правам человека в Российской Федерации» // Собрание законодательства РФ. 1997. № 9. Ст. 1011.

5. Федеральный закон от 12.01.1996 № 7-Ф3 (в ред. от 05.04.2021 № 75-Ф3) «О некоммерческих организациях» // Собрание законодательства РФ. 1996. № 3. Ст. 145.

6. Федеральный закон от 11.08.1995 № 135-Ф3 (в ред. от 08.12.2020 № 429-Ф3) «О благотворительной деятельности и добровольчестве (волонтерстве)» // Собрание законодательства РФ. 1995. № 33. Ст. 3340.

7. Указ Президента РФ от 13.10.2004 № 1313 (в ред. от 02.09.2021 № 512) «Вопросы Министерства юстиции Российской Федерации» // Собрание законодательства РФ. 2004. № 42. Ст. 4108.

8. Приказ Генпрокуратуры России от 02.08.2018 № 471 «Об организации в органах прокуратуры Российской Федерации работы по правовому просвещению и правовому информированию» // Законность. 2018. № 9.

9. Устав Архангельской области от 23.05.1995 (в ред. от 21.12.2020 № 352-22-О3) // Волна. 2001. 3 апреля. 
10. Уставный закон Калининградской области от 02.07.2010 № 480 (в ред. от 25.06.2021 № 576) «Об Уполномоченном по правам человека в Калининградской области» // Калининградская правда. 2010. 8 июля.

11. Уставный закон Красноярского края от 16.06.2016 № 10-4679 (в ред. от 24.12.2020 № 10-4655) «Об Уполномоченном по правам человека в Красноярском крае» // Наш Красноярский край. 2016. 6 июля.

12. Конституционный закон Чеченской Республики от 08.02.2006 № 1-РКЗ (в ред. от 15.03.2021 № 1-РКЗ) «Об Уполномоченном по правам человека в Чеченской Республике» // Вести Республики. 2006. 10 февраля.

13. Конституционный закон Республики Тыва от 30.06.1999 № 250 (в ред. от 17.05.2021 № 49-КЗРТ) «Об Уполномоченном по правам человека в Республике Тыва» // Собрание законодательства Республики Тыва. 2001. № 2. Ст. 113.

14. Закон Владимирской области от 27.12.2017 № 134-О3 «О правовом просвещении граждан на территории Владимирской области» // Владимирские ведомости. 2017. 30 декабря.

15. Закон Воронежской области от 01.12.2017 № 176-О3 (в ред. от 26.09.2018 № 114-О3) «О правовом просвещении граждан на территории Воронежской области» // Информационная система «Портал Воронежской области в сети Интернет». URL: http://www.govvrn.ru, 04.12.2017.

16. Закон Курганской области от 02.12.2016 № 99 «О правовом просвещении граждан на территории Курганской области» // Официальный интернет-портал правовой информации. URL: http://www.pravo.gov.ru, 06.12.2016.

17. Областной закон Ленинградской области от 15.06.2020 № 67-оз «О правовом информировании и правовом просвещении граждан на территории Ленинградской области» // Официальный интернет-портал Администрации Ленинградской области. URL: http://www.lenobl.ru, 15.06.2020.

18. Закон Самарской области от 27.12.2018 № 117-ГД «О правовом просвещении граждан на территории Самарской области» // Волжская коммуна. 2019. 11 января.

19. Закон Тверской области от 05.06.2020 № 42-3О «О правовом просвещении граждан на территории Тверской области» // Тверские ведомости. 2020. 10-16 июня.

20. Закон Томской области от 02.10.2008 № 197-О3 «О просветительской деятельности в Томской области» // Собрание законодательства Томской области. 2008. № 10(39).

21. Закон Владимирской области от 05.09.2002 № 94-ОЗ (в ред. от 10.06.2003 № 53-О3, с изм. от 29.12.2004 № 242-О3) «О целевой программе «Правовое просвещение и воспитание населения на 2003-2005 годы» // Вестник Законодательного Собрания Владимирской области. 2002. № 4(44). 2 часть. стр. 77.

22. Распоряжение Правительства Республики Бурятия от 19.07.2018 № 397-р «Об утверждении Плана мероприятий по правовому просвещению населения Республики Бурятия на среднесрочную перспективу» // Официальный Интернет-портал Правительства Республики Бурятия www.egov-buryatia.ru, 20.07.2018; Постановление Правительства Республики Марий Эл от 17.09.2019 № 278 «О республиканской программе «Правовое просвещение граждан в Республике Марий Эл» на 2020 -2022 годы» // Официальный интернет-портал Республики Марий Эл марийэл.рф, 17.09.2019; Распоряжение Правительства Хабаровского края от 08.07.2020 № 741-рп (в ред. от 02.11.2021 № 1078-рп) «О Плане мероприятий по правовому информированию и правовому просвещению населения в Хабаровском крае в 2020 - 2022 годах» // Официальный интернет-портал нормативных правовых актов Хабаровского края. URL: http://laws.khv.gov.ru, 13.07.2020.

23. Закон г. Москвы от 20.12.2006 № 65 (в ред. от 26.12.2018 № 38) «О Правительстве Москвы» // Ведомости Московской городской Думы. 2007. № 2. Ст. 385; Закон города Севастополя от 30.04.2014 № 5-3С (в ред. от 02.07.2019 № 515-3С) «О Правительстве Севастополя» // Севастопольские известия. 2014. 30 апреля.

24. Закон Алтайского края от 08.04.2013 № 11-3С (в ред. от 05.05.2021 № 43-3С) «О бесплатной юридической помощи в Алтайском крае» // Алтайская правда. 2013. 13 апреля.

25. Закон Забайкальского края от 14.03.2018 № 1569-33К (в ред. от 26.04.2019 № 1719-33К) «Об отдельных вопросах профилактики правонарушений в Забайкальском крае» // Официальный интернет-портал правовой информации. URL: http://www. pravo.gov.ru, 15.03.2018.

26. Закон Пермского края от 06.11.2019 № 462-ПК «О профилактике правонарушений в Пермском крае» // Бюллетень законов Пермского края, правовых актов губернатора Пермского края, Правительства Пермского края, исполнительных органов государственной власти Пермского края. 2019. № 44.

27. Закон Чукотского автономного округа от 23.10.2017 № 74-О3 «О регулировании отдельных вопросов профилактики правонарушений в Чукотском автономном округе» // Ведомости. 2017. 27 октября.

28. Закон Республики Дагестан от 04.04.2016 № 20 (в ред. от 29.12.2018 № 98) «О профилактике экстремистской деятельности в Республике Дагестан» // Дагестанская правда.2016. 6 апреля; Закон Республики Ингушетия от 29.12.2018 № 51-P3 «О профилактике экстремистской деятельности в Республике Ингушетия» // Сердало. 2019. 12 января.

29. Закон Московской области от 14.06.2019 № 116/2019-О3 (в ред. от 21.05.2020 № 98/2020-О3) «О профилактике правонарушений в Московской области среди лиц, отбывших уголовное наказание в виде лишения свободы» // Ежедневные Новости. Подмосковье. 2019. 28 июня.

30. Закон Республики Башкортостан от 23.03.1998 № 151-з (в ред. от 25.12.2018 N 50-з) «О системе профилактики безнадзорности и правонарушений несовершеннолетних, защиты их прав в Республике Башкортостан» // Ведомости Государственного Собрания, Президента и Кабинета Министров Республики Башкортостан. 1998. № 13(79). Ст. 778; Закон Тверской области от 14.02.2007 № 6-3О (в ред. от 02.12.2016 № 79-3О) «Об организации деятельности по профилактике безнадзорности и правонарушений несовершеннолетних в Тверской области» // Тверские ведомости. 2007. 16-22 февраля; Закон Саратовской области от 05.08.2014 № 89-3СО (в ред. от 25.02.2021 № 20-3СО) «Об организации деятельности комиссий по делам несовершеннолетних и защите их прав в Саратовской области и наделении органов местного самоуправления государственными полномочиями по созданию и организации деятельности комиссий по делам несовершеннолетних и защите их прав» 
// Собрание законодательства Саратовской области. 2014. № 33. Август; Закон Республики Крым от 01.09.2014 № 63-3РК (в ред. от 09.01.2018 № 460-3РК/2018) «О системе профилактики безнадзорности и правонарушений несовершеннолетних в Республике Крым» // Крымские известия. 2014. 10 сентября.

31. Закон Курганской области от 28.06.2017 № 49 (в ред. от 30.06.2020 № 71) «О профилактике правонарушений в Курганской области» // Официальный интернет-портал правовой информации. URL: http://www.pravo.gov.ru, 30.06.2017; Закон Свердловской области от 29.10.2013 № 113-О3 (в ред. от 09.04.2021 № 25-О3) «О реализации молодежной политики на территории Свердловской области» // Собрание законодательства Свердловской области. 2013. № 10-1. Ст. 1886.

32. Закон Республики Дагестан от 08.06.2015 № 60 (в ред. от 16.03.2020 № 11) «О народных дружинах в Республике Дагестан» // Собрание законодательства Республики Дагестан. 2015. № 11. Ст. 601.

33. Закон Алтайского края от 05.03.2021 № 17-3С «О статусе педагогического работника в Алтайском крае» // Официальный интернет-портал правовой информации. URL: http://pravo.gov.ru, 05.03.2021.

34. Закон Архангельской области от 03.06.2003 № 171-22-О3 (в ред. от 28.09.2015 № 329-19-О3) «О социально-правовой защите и реабилитации лиц, подвергшихся насилию в семье» // Волна. 2003. 20 июня.

35. Закон Карачаево-Черкесской Республики от 14.05.2015 № 12-Р3 (в ред. от 22.02.2017 № 11-Р3) «О профилактике правонарушений в Карачаево-Черкесской Республике» // ДР. Официальная среда. 2015. 23 мая; Закон Хабаровского края от 21.12.2016 № 232 «О регулировании отдельных вопросов профилактики правонарушений в Хабаровском крае» // Собрание законодательства Хабаровского края. 2017. № 12 (том 1); Закон Еврейской автономной области от 22.12.2016 № 63-О3 (в ред. от 30.03.2020 № 538-О3) «Об основах системы профилактики правонарушений в Еврейской автономной области» // Сетевое издание «Сборник правовых актов Еврейской автономной области и иной официальной информации». URL: http://npa79. eao.ru, 11.01.2017.

36. Закон Забайкальского края от 14.03.2018 № 1569-33К (в ред. от 26.04.2019 № 1719-33К) «Об отдельных вопросах профилактики правонарушений в Забайкальском крае» // Официальный интернет-портал правовой информации. URL: http:// www.pravo.gov.ru, 15.03.2018; Закон Пермского края от 06.11.2019 № 462-ПК «О профилактике правонарушений в Пермском крае» // Бюллетень законов Пермского края, правовых актов губернатора Пермского края, Правительства Пермского края, исполнительных органов государственной власти Пермского края. 2019. № 44.

37. Закон города Севастополя от 25.07.2014 № 51-ЗС (в ред. от 08.07.2019 № 516-3С) «О мерах по профилактике безнадзорности и правонарушений несовершеннолетних в городе Севастополе» // Севастопольские известия. 2014. 30 июля.

38. Закон Московской области от 30.12.2005 № 273/2005-О3 (в ред. от 30.06.2020 № 132/2020-О3) «О комиссиях по делам несовершеннолетних и защите их прав в Московской области» // Ежедневные Новости. Подмосковье. 2006. 12 января.

39. Закон Волгоградской области от 02.12.2008 № 1789-ОД (в ред. от 26.12.2014 № 189-ОД) «Об административных комиссиях» // Волгоградская правда. 2008. 10 декабря; Закон Республики Мордовия от 17.10.2002 № 45-3 (ред. от 18.08.2020 № 55-3) «Об административных комиссиях в Республике Мордовия» // Ведомости Государственного Совета Республики Мордовия. 2003. № 20-21(48). Ст. 690.

40. Закон Калужской области от 27.04.2007 № 305-О3 (в ред. от 30.09.2013 № 477-О3) «О противодействии коррупции в Калужской области» // Весть. 2009. 3 июня. Закон Калининградской области от 26.05.2017 № 73 (в ред. от 22.02.2019 № 269) «О противодействии коррупции в Калининградской области» // Калининградская правда. 2017. 31 мая.

41. Постановление Правительства Санкт-Петербурга от 22.10.2019 № 740 (в ред. от 20.09.2021 № 700) «Об утверждении Плана мероприятий по реализации Стратегии социально-экономического развития Санкт-Петербурга на период до 2035 года». URL: https://docs.cntd.ru/document/563565273. (дата обращения: 16.11.2021).

42. Закон Саратовской области от 05.03.2004 № 12-3СО (в ред. от 29.09.2021 № 96-3СО) «Об избирательной комиссии Саратовской области» // Саратов - столица Поволжья. 2004. 17 марта; Закон Тамбовской области от 25.12.2012 № 229-3 (в ред. от 03.08.2021 № 656-3) «О выборах депутатов представительных органов муниципальных образований в Тамбовской области» // Тамбовская жизнь. 2012. 28 декабря; Закон Республики Мордовия от 19.02.2007 № 16-3 (в ред. от 08.06.2021 № 28-3) «О выборах депутатов представительных органов муниципальных образований в Республике Мордовия» // Ведомости Государственного Совета Республики Мордовия. 2007. № 32(80). Ст. 907.

43. Закон Пермского края от 20.02.2007 № 3-ПК (в ред. от 07.06.2021 № 651-ПК) «Об Избирательной комиссии Пермского края» // Собрание законодательства Пермского края. 2007. № 3. Закон Пермского края от 20.02.2007 № 4-ПК (в ред. от 07.06.2021 № 651-ПК) «О территориальных избирательных комиссиях Пермского края» // Собрание законодательства Пермского края. 2007. № 3.

44. Закон Ярославской области от 07.11.2014 № 68-3 (в ред. от 07.04.2021 № 23-3) «Об Избирательной комиссии Ярославской области» // Документ-Регион. 2014. 11 ноября.

45. Закон Воронежской области от 11.03.2013 № 02-О3 (в ред. от 22.05.2019 № 75-О3) «О добровольческой (волонтерской) деятельности» // Собрание законодательства Воронежской области. 2013. № 8. Ст. 140. Закон Тверской области от 28.09 .2018 № 42-3О «О добровольческой (волонтерской) деятельности в Тверской области» // Тверские ведомости. 2018. 3-10 октября. Закон Пензенской области от 23.09.2003 № 516-ЗПО (в ред. от 28.04.2018 № 3183-ЗПО) «О благотворительной деятельности и добровольчестве (волонтерстве) в Пензенской области» // Пензенские губернские ведомости. 2003. 14 октября. Закон Удмуртской Республики от 27.12.2019 № 78-Р3 «О поддержке добровольческой (волонтерской) деятельности на территории Удмуртской Республики» // Известия Удмуртской Республики. 2020. 14 января. Закон Алтайского края от 11.11.2019 № 87ЗС (в ред. от 08.07.2020 № 42-3С) «О благотворительной деятельности и добровольчестве (волонтерстве) в Алтайском крае» // Официальный интернет-портал правовой информации. URL: http://www.pravo.gov.ru, 12.11.2019; Закон Краснодарского края от 30.04.2002 № 473-К3 (в ред. от 11.02.2019 № 3972-К3) «О благотворительной деятельности и добровольчестве (волонтерстве) в Краснодарском крае» // Кубанские новости. 2002. 21 мая. 
46. Закон Брянской области от 25.12.2017 № 108-3 «О содействии деятельности казачьих обществ и общественных объединений казаков на территории Брянской области» // Официальный интернет-портал правовой информации. URL: http://www. pravo.gov.ru, 27.12.2017.

47. Закон Воронежской области от 06.10.2011 № 134-О3 (в ред. от 27.04.2021 № 57-О3) «О государственной (областной) поддержке социально ориентированных некоммерческих организаций в Воронежской области» // Молодой коммунар. 2011.11 октября; Закон Тамбовской области от 26.05.2011 № 14-3 (в ред. от 30.03.2020 № 471-3) «О государственной поддержке социально ориентированных некоммерческих организаций в Тамбовской области» // Тамбовская жизнь. 2011. 31 мая; Закон Ярославской области от 06.12.2012 № 56-3 (в ред. от 02.04.2019 № 23-3) «О государственной поддержке социально ориентированных некоммерческих организаций в Ярославской области» // Документ-Регион. 2012. 11 декабря; Закон Мурманской области от 05.03.2012 № 1450-01-3МО (в ред. от 08.04.2021 № 2617-01-3МО) «О государственной поддержке социально ориентированных некоммерческих организаций в Мурманской области» // Мурманский Вестник. 2012. 13 марта; Закон Псковской области от 02.03.2012 № 1136-О3 (в ред. от 13.06.2018 № 1862-О3) «О государственной поддержке социально ориентированных некоммерческих организаций на территории Псковской области» // Псковская правда. 2012. 6 марта; Областной закон Ростовской области от 11.11.2010 № 492-3С (в ред. от 04.08.2020 № 351-3С) «О государственной поддержке социально ориентированных некоммерческих организаций в Ростовской области» // Наше время. 2010. 23 ноября; Закон Нижегородской области от 07.05.2009 № 52-3 (в ред. от 02.07.2020 № 66-3) «О государственной поддержке социально ориентированных некоммерческих организаций в Нижегородской области» // Правовая среда. 2009. 21 мая. Закон Оренбургской области от 06.05.2014 № 2263/649-V-O3 (в ред. от 07.12.2020 № 2521/710-VI-O3) «О государственной поддержке социально ориентированных некоммерческих организаций в Оренбургской области» // Оренбуржье. 2014. 22 мая; Закон Самарской области от 10.12.2012 № 127-ГД (в ред. от 05.10.2018 № 78-ГД) «О государственной поддержке социально ориентированных некоммерческих организаций в Самарской области» // Волжская коммуна. 2012. 11 декабря и др.

48. Закон Архангельской области от 27.04.2011 № 281-21-О3 (в ред. от 30.03.2021 № 391-24-О3) «О взаимодействии органов государственной власти Архангельской области и некоммерческих организаций» // Волна. 2011. 3 мая.

49. Областной закон Новгородской области от 01.12.2014 № 659-О3 «О Концепции миграционной политики Новгородской области на период до 2025 года» // Новгородские ведомости. 2014. 5 декабря.

50. Распоряжение Правительства Удмуртской Республики от 15.12.2014 № 949-р (в ред. от 17.07.2019 № 949-р) «Об утверждении Концепции миграционной политики Удмуртской Республики на период до 2025 года» // Официальный сайт Главы Удмуртской Республики и Правительства Удмуртской Республики. URL: http://www.udmurt.ru, 23.12.2014; Постановление Губернатора Владимирской области от 22.07.2013 № 847 (в ред. от 15.12.2014 № 1270) «Об утверждении Концепции реализации государственной миграционной политики Российской Федерации на период до 2025 года во Владимирской области» // Владимирские ведомости. 2013. 27 июля.

51. Указ Президента РФ от 31.10.2018 № 622 «О Концепции государственной миграционной политики Российской Федерации на 2020-2022 годы» // Собрание законодательства РФ. 2018. № 45. Ст. 6917.

52. Закон Республики Татарстан от 10.10.2011 № 72-ЗРТ (в ред. от 05.04.2021 № 17-3РТ) «Об обеспечении защиты жилищных прав граждан» // Ведомости Государственного Совета Татарстана. 2011. № 10. Ст. 1214.

53. Закон Архангельской области от 02.07.2012 № 522-32-О3 (в ред. от 26.04.2021 № 398-25-О3) «Об организации деятельности в сфере защиты прав граждан, чьи денежные средства привлечены для строительства многоквартирных домов и (или) иных объектов недвижимости, включенных в единый реестр проблемных объектов и расположенных на территории Архангельской области» // Волна. 2012. 10 июля.

54. Закон г. Москвы от 30.09.2009 № 39 (в ред. от 24.03.2021 № 6) «О молодежи» // Ведомости Московской городской Думы. 2009. № 11. Ст. 281; Закон Свердловской области от 29.10.2013 № 113-О3 (в ред. от 09.04.2021 № 25-О3) «О реализации молодежной политики на территории Свердловской области» // Собрание законодательства Свердловской области. 2013. № 10-1. Ст. 1886.

55. Закон г. Москвы от 12.03.2008 № 11 (в ред. от 11.12.2019 № 35) «Об охране труда в городе Москве» // Ведомости Московской городской Думы. 2008. № 4. Ст. 48.

56. Постановление Правительства Забайкальского края от 04.09.2020 № 372 «Об утверждении региональной программы «Укрепление общественного здоровья в Забайкальском крае на 2020 - 2024 годы» // Официальный интернет-портал правовой информации. URL: http://www.pravo.gov.ru, 08.09.2020.

57. Областной закон от 06.05.1997 № 29-ОЗ (в ред. от 29.07.2021 № 76-О3) «Об Уставном Суде Свердловской области» // Собрание законодательства Свердловской области. 1997. № 5. Ст. 930.

58. Закон Республики Бурятия от 04.03.2016 № 1655-V «О некоторых вопросах деятельности нотариата на территории Республики Бурятия» // Официальный Интернет-портал Правительства Республики Бурятия. URL: http://www.egov-buryatia.ru, 09.03.2016.

59. Закон Брянской области от 25.12.2017 № 108-3 «О содействии деятельности казачьих обществ и общественных объединений казаков на территории Брянской области» // Официальный интернет-портал правовой информации. URL: http://www. pravo.gov.ru, 27.12.2017.

60. Постановление Губернатора Владимирской области от 26.12.2003 № 634 (в ред. от 22.05.2019 № 369) «О координационном совете Владимирской области по правовому просвещению населения» // Владимирские ведомости. 2004. 21 января; Распоряжение Правительства Ивановской области от 07.03.2018 № 27-рп (в ред. от 10.03.2020 № 19-рп) «О создании координационной группы по вопросам оказания бесплатной юридической помощи, правовому информированию и правовому просвещению населения на территории Ивановской области». URL: https://docs.cntd.ru/document/446663291 (дата обращения: 17.11.2021); Распоряжение Администрации Смоленской области от 13.05.2016 № 587-р/адм (в ред. от 03.02.2021 № 154-р/ 
адм)) «О создании Межведомственной комиссии при Администрации Смоленской области по вопросам повышения правовой культуры населения, правового просвещения населения и оказания гражданам бесплатной юридической помощи в Смоленской области». URL: https://docs.cntd.ru/document/439055110 (дата обращения: 17.11.2021); Постановление администрации Тамбовской области от 24.09.2018 N 958 (в ред. от 01.07.2021 № 463) «Об организационном комитете по вопросам оказания бесплатной юридической помощи, правового информирования, правового просвещения и повышения правовой культуры населения на территории Тамбовской области» // Сайт сетевого издания «Тамбовская жизнь». URL: http://www. tamlife.ru, 26.09.2018; Указ Губернатора Архангельской области от 17.04.2012 № 46-у «Об утверждении положения о совете при Губернаторе Архангельской области по организации бесплатной юридической помощи, правового информирования и правового просвещения населения на территории Архангельской области» // Волна. 2012. 1 мая; Распоряжение Кабинета Министров Чувашской Республики от 25.03.2021 № 204-р «О создании рабочей группы по организации правового информирования и правового просвещения населения по должностям и признании утратившими силу некоторых распоряжений Кабинета Министров Чувашской Республики» // Вести Чувашии. 2021. 9 апреля.

61. Указ Президента Республики Марий Эл от 30.09.2009 № 197 (в ред. от 26.03.2015 № 68) «Об утверждении Концепции правового просвещения граждан в Республике Марий Эл» // Марийская правда. 2009. 10 октября; Постановление Правительства Республики Марий Эл от 17.09.2019 № 278 «О республиканской программе «Правовое просвещение граждан в Республике Марий Эл» на 2020-2022 годы» // Официальный интернет-портал Республики Марий Эл. URL: http://мapийэл.pф, 17.09.2019; Распоряжение Правительства Ханты-Мансийского автономного округа - Югры от 29.12.2018 № 731-рп «О Концепции правового просвещения граждан, проживающих в Ханты-Мансийском автономном округе - Югре». URL: https:// upch.admhmao.ru/pravovoe-prosveshchenie-grazhdan-/1187716/ (дата обращения: 17.11.2021); Распоряжение Правительства Республики Бурятия от 19.07.2018 № 397-р «Об утверждении Плана мероприятий по правовому просвещению населения Республики Бурятия на среднесрочную перспективу» // Официальный Интернет-портал Правительства Республики Бурятия. URL: http://www.egov-buryatia.ru, 20.07.2018; Распоряжение Правительства Алтайского края от 27.08.2019 № 326-p «Об утверждении плана мероприятий по правовому просвещению населения Алтайского края на 2020 - 2023 годы». URL: https://docs.cntd.ru/document/561519674 (дата обращения: 17.11.2021); Распоряжение Правительства Хабаровского края от 08.07.2020 № 741-рп «О Плане мероприятий по правовому информированию и правовому просвещению населения в Хабаровском крае в 2020 - 2022 годах» // Официальный интернет-портал нормативных правовых актов Хабаровского края. URL: http://laws.khv.gov.ru, 13.07.2020; Постановление Правительства Нижегородской области от 06.09.2021 № 801 «Об утверждении плана мероприятий («дорожной карты») по правовому просвещению граждан и оказанию правовой помощи на территории Нижегородской области на 2021-2023 годы» // Официальный интернет-портал правовой информации. URL: http://pravo.gov.ru, 07.09.2021.

62. Постановление Правительства Архангельской области от 01.10.2019 № 544-пп «Об утверждении Положения о порядке правового информирования и правового просвещения населения Архангельской области» // Официальный интернетпортал правовой информации. URL: http://www.pravo.gov.ru, 09.10.2019; Постановление Правительства Пермского края от 25.07.2014 № 688-п «Об утверждении Порядка правового информирования и правового просвещения населения Пермского края» // Бюллетень законов Пермского края, правовых актов губернатора Пермского края, Правительства Пермского края, исполнительных органов государственной власти Пермского края. 2014. № 30 .

63. Постановление Совета министров Республики Крым от 07.02.2017 № 49 «Об утверждении Положения о порядке организации деятельности исполнительных органов государственной власти Республики Крым, отнесенных к их ведению государственных учреждений Республики Крым по правовому просвещению и взаимодействию с общественностью» // Официальный сайт Правительства Республики Крым. URL: http://rk.gov.ru, 07.02.2017.

64. Указ Губернатора Архангельской области от 08.04.2010 № 53-у (в ред. от 09.07.2020 № 104-у) «О правовом департаменте администрации Губернатора Архангельской области и Правительства Архангельской области» // Волна. 2010.20 апреля; Постановление Правительства Новосибирской области от 20.07.2016 № 215-п (в ред. от 01.06.2021 № 197-п) «О министерстве юстиции Новосибирской области» // Советская Сибирь. 2016. 27 июля; Постановление Губернатора Ярославской области от 22.02.2008 № 139 (в ред. от 22.11.2019 № 198-р) «О правовом управлении Правительства области» // Губернские вести. 2008. 9 апреля.

65. Постановление Орловского областного Совета народных депутатов от 27.03.2020 № 45/1259-ОС «О Положении об аппарате Уполномоченного по правам ребенка в Орловской области». URL: https://docs.cntd.ru/document/570729494 (дата обращения: 17.11.2021). 


\section{Organisation of legal awareness raising in the subJects OF the Russian Federation}

\section{P. Kabanov*}

Keywords: monitoring, regulation, awareness raising, subjects of awareness raising, bodies of the Ministry of Justice, subjects of the Russian Federation.

\section{Abstract.}

Purpose of the work: studying the main questions of legal regulation of the organisation and implementation of legal awareness raising in the subjects of the Russian Federation.

Method of study: comparative analysis of current laws and legal doctrines combined with comparative legal analysis of the field of legal regulation under study.

Results obtained: an assessment of regional legal regulations on the organisation of legal awareness raising is presented, the main subjects of the organisation and implementation of legal awareness raising in Russia's regions are identified, a classification of types of legal awareness raising is given. The main shortcomings of legal regulation of legal awareness raising in the subjects of the Russian Federation are identified and measures to remedy them are put forward. The organisation and implementation of legal awareness raising in the subjects of the Russian Federation are regulated by numerous regulations of different legal force covering various aspects of legal regulation of the activities of public administration bodies: it is not enough to have special regulations covering only the organisation and implementation of legal awareness raising. It is recommended that the subjects of the Russian Federation should more widely use the practice of adopting special laws regulating the questions of legal awareness raising as well as regional programmes (plans) for implementing these laws. The regional bodies of the Ministry of Justice or other agencies granted powers to monitor the organisation and implementation of legal awareness raising should be charged with controlling the administration of laws on legal awareness raising.

\section{References}

1. Adaeva O.V., Kartygin N.S. Znachenie pravovogo prosveshcheniia v pravovospitatel'nom protsesse kak sredstva bor'by s pravovym nigilizmom. Voprosy sovremennoi iurisprudentsii, 2016, No. 6 (57), pp. 107-111.

2. Alekseev A.N. K voprosu o poniatii i sushchnosti pravovogo monitoringa. Rossiiskaia iustitsiia, 2011, No. 10, pp. 2-7.

3. Andrianov A.N., Boldyrev V.B., Boshno S.V., Brizitskii A.M. Pravovoi monitoring : uchebnoe posobie. M. : Iurisprudentsiia, 2012. $415 \mathrm{pp}$.

4. Andrianova D.V. Monitoring deiatel'nosti sub"ektov Rossiiskoi Federatsii v sfere pravovogo prosveshcheniia v 2016 godu. Monitoring pravoprimeneniia, 2017, No. 3(24), pp. 66-70.

5. Astanin V.V. Kontseptsiia metodicheskogo obespecheniia kriminologicheskogo prosveshcheniia roditelei o prestupnosti protiv nesovershennoletnikh. Monitoring pravoprimeneniia, 2017, No. 1(22), pp. 4-6.

6. Bozhko A.S. Evoliutsiia tekhnologii instituta pravovogo prosveshcheniia v Rossii v XX -- nachale XXI vv.. Vestnik Rossiiskogo novogo universiteta, seriia: Chelovek i obshchestvo, 2021, No. 3, pp. 113-118.

7. Bolelova A.G., Lekareva E.E. Pravovoe prosveshchenie v sisteme obrazovaniia: monitoringovoe issledovanie. Obrazovanie lichnosti, 2016, No. 4, pp. 147-154.

8. Varkova S.A. Monitoring zakonodatel'stva i pravoprimenitel'noi praktiki (teoretiko-pravovoe issledovanie): avtoref. dis.... kand. iurid. nauk. M. : Rossiiskaia akademiia narodnogo khoziaistva i gosudarstvennoi sluzhby pri Prezidente RF, 2013. 22 pp.

9. Garmaev Iu.P., Popova E.I. Organizatsiia antikriminal'nogo i antiterroristicheskogo prosveshcheniia v Krymskom federal'nom okruge. Vserossiiskii kriminologicheskii zhurnal, 2016, t. 10, No. 2, pp. 270-279.

10. Garmaev Iu.P., Chumakova L.P. Kontseptsiia antikriminal'nogo prosveshcheniia v Rossiiskoi Federatsii i uchastie iuridicheskikh vuzov, studencheskoi molodezhi v ee realizatsii. Sovremennaia nauka: aktualnye problemy teorii i praktiki, seriia: Gumanitarnye nauki, 2018, No. 12-2, pp. 63-67.

11. Gorokhov D.B., Radchenko V.I., Chernogor N.N., Chesnokova M.D. Pravovoi monitoring: aktual'nye problemy teorii i praktiki : monografiia. Moskva, 2010. 232 pp.

12. Grigorian K.Iu. Zashchita prav grazhdan v forme pravovogo prosveshcheniia: opyt Respubliki Komi. Vestnik. Gosudarstvo i pravo, 2011, No. 14, pp. 30-32.

Pavel Kabanov, Dr.Sc. (Law), Associate Professor, Director of the Research Institute for Combating Corruption of Timiryasov Kazan Innovation University, Kazan, Russian Federation. E-mail: kabanovp@mail.ru 
13. Dolinina I.G., Shakirova E.A. Pravovoe prosveshchenie: kontseptual'nye osnovy. Vysshee obrazovanie segodnia, 2013, No. 3, pp. 49-52.

14. Dotsenko A.S. O poniatii pravovogo prosveshcheniia. Aktual'nye problemy rossiiskogo prava, 2020, t. 15, No. 1 (110), pp. 179-188.

15. Zubenko E.V., Bugaev E.N., Garmaeva D.A. O vozmozhnosti razvitiia pravovogo (antikriminal'nogo) prosveshcheniia uchastnikov ugolovnogo sudoproizvodstva silami kriminalisticheskoi nauki. Zakon i pravo, 2019, No. 8, pp. 131-135.

16. Ivanova L.A. Opredelenie effektivnosti normativnykh pravovykh aktov v protsesse pravovogo monitoringa: dis. ... kand. iurid. nauk. M. : Moskovskii novyi iuridicheskii institut, 2011. 175 pp.

17. Kapitsyna D.V. Pravovoi monitoring (poniatie, napravleniia, sub"ekty, urovni). Konstitutsionnoe i munitsipal'noe pravo, 2012, No. 8, pp. 25-29.

18. Lebedev S.Ia. Kriminologicheskoe prosveshchenie v sisteme pravovogo vospitaniia naseleniia. Kriminologicheskii zhurnal, 2003, No. 1, pp. 34-36.

19. Lekareva E.E. Programmno-metodicheskoe i informatsionnoe obespechenie pravovogo prosveshcheniia $\mathrm{v}$ sisteme obrazovaniia. Obrazovanie lichnosti, 2017, No. 3, pp. 108-115.

20. Mikov P.V. Pravovoe prosveshchenie v deiatel'nosti Upolnomochennogo po pravam cheloveka v Permskom krae. Aktual'nye problemy sovremennogo mezhdunarodnogo prava. Materialy XVI Mezhdunarodnogo kongressa "Blishchenkovskie chteniia": v 3 chastiakh. M. : Rossiiskii universitet druzhby narodov, 2019, pp. 310-318.

21. Mironov O.O. Pravovoe prosveshchenie -- funktsiia ombudsmenov. Pravo i obrazovanie, 2009, No. 5, pp. 13-29.

22. Narenkova A.A., Iarkina A.I. Sovershenstvovanie mekhanizma pravovogo prosveshcheniia upolnomochennykh po pravam cheloveka v sub"ektakh Rossiiskoi Federatsii. Matritsa nauchnogo poznaniia, 2021, No. 3-2, pp. 131-138.

23. Neveselov A.A. Pravovoi monitoring i gosudarstvennaia politika (teoretiko-pravovye osnovy vzaimodeistviia): dis. ... kand. iurid. nauk. Rostov-na-Donu : Rostovskii iuridicheskii institut MVD Rossiiskoi Federatsii, 2009. 180 pp.

24. Neustroeva A.M. Pravovoe prosveshchenie v Respublike Sakha (Iakutiia). Aktual'nye problemy reformirovaniia sovremennogo zakonodatel'stva: sbornik statei Mezhdunarodnoi nauchno-prakticheskoi konferentsii. Ufa: OOO “Aeterna”, 2017, pp. 31-33.

25. Omel'chenko D.E. Poniatie i znachenie pravovogo monitoringa. Novaia nauka: Opyt, traditsii, innovatsii, 2016, No. 10-2, pp. 189-192.

26. Pravovoi monitoring: nauchno-prakticheskoe posobie. Andrianov A.N., Boldyrev V.B., Boshno S.V. i dr.; pod red. Iu. A. Tikhomirova, D. B. Gorokhova. M. : Institut zakonodatel'stva i sravnitel'nogo pravovedeniia pri Pravitel'stve RF, 2009. 415 pp.

27. Sologub A.Iu. Pravovoi monitoring: poniatie i znachenie. Rossiiskaia iustitsiia, 2015, No. 8, pp. 11-13.

28. Suchilina A.S., Khabarova M.A. Pravovoe prosveshchenie grazhdan v ramkakh deiatel'nosti upolnomochennogo po pravam cheloveka. Uchenye zapiski Tambovskogo otdeleniia RoSMU, 2020, No. 20, pp. 246-251.

29. Fadeeva A.S. Analiticheskaia funktsiia pravovogo monitoringa: dis. ... kand. iurid. nauk. M. : Rossiiskii universitet kooperatsii, 2011. $169 \mathrm{pp}$.

30. Filippova N.A. Institutsionalizatsiia pravovogo prosveshcheniia v Rossiiskoi Federatsii. Politicheskaia ekspertiza: POLITEKS, 2019, t. 15 , No. 1 , pp. $36-44$.

31. Khil' I.M., Khoroshen'kova M.Iu. Pravovoe prosveshchenie i pravovoe informirovanie kak faktory formirovaniia pravovogo soznaniia molodezhi. Ocherki noveishei kameralistiki, 2021, No. 1, pp. 85-89.

32. Cherepanova E.V. Obespechenie planirovaniia pravovogo monitoringa. Zhurnal rossiiskogo prava, 2013, No. 4 (196), pp. $59-64$.

33. Shibalova T.V., Zolotarev R.I. Pravovoe prosveshchenie v Respublike Marii El. Iuridicheskii mir, 2012, No. 7, pp. 6-8. 


\section{НЕКОТОРЫЕ ПРИЗНАКИ, ХАРАКТЕРИЗУЮЩИЕ КОРРУПЦИОННУЮ ПРЕСТУПНОСТЬ В АГЛОМЕРАЦИЯХ

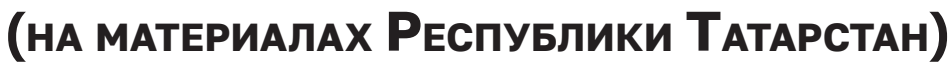

Ахунов Д. Р. ${ }^{1}$

Ключевые слова: коррупция, коррупционные преступления, криминологическая характеристика преступлений, показатели преступности, агломерация, городская агломерация.

Аннотация.

Цель работы: анализ отдельных показателей (состояние, динамика и удельный вес) коррупционной преступности, регистрируемой на территории агломераций Республики Татарстан, которые характеризуют коррупциогенность данных систем расселения населения.

Методы исследования: логический, системно-структурный, математический и статистический методы.

Результаты исследования: криминологический анализ отдельных показателей (признаков) регистрируемой коррупционной преступности в агломерациях Республики Татарстан за период 2018-2020 годов позволил сделать ряд выводов. Во-первых, результаты исследования указывают на повышенную коррупциогенность агломерационных образований. Во-вторых, определена корреляция между размерами и развитием данных систем расселения населения и уровнем коррупционных преступлений в них. В-третьих, консолидация агломерациями подавляющего большинства регистрируемых коррупционных преступлений на территориях указывает на необходимость изучения детерминации и особенностей преступных проявлений коррупции в данном, региональном аспекте. В-четвертых, требуется выработка эффективных мер противодействия коррупционным преступлениям в рассматриваемых территориальных образованиях, заметно ухудшающих криминогенную обстановку в России и ее отдельных регионах.

DOI: 10.21681/2226-0692-2021-4-68-73

\section{Введение}

$\mathrm{H}$ роль в развитии и функционировании общества приобретает явление урбанизации, находящее свое проявление в концентрации населения и экономики в крупнейших формах расселения [10, с. 141-142]. Результатом данного процесса выступает активное агломерирование территорий [3, с. 5-6], которое, помимо явных преимуществ экономического характера в сравнении с иными системами расселения населения [4, с. 106], обладает многочисленными особенностями [7] и порождает проблемы [6, с. 46, 48, 50], одна из которых - в сфере противодействия коррупции.

Несмотря на общую однородность коррупции [2, c. 120], агломерации (городские агломерации) относят к субъектам, на уровне которых она имеет особенности проявления, так как распространение данного негативного явления имеет особое место, как правило, в регионах, обладающих наибольшим экономическим потенциалом, где этот потенциал сконцентрирован в ограниченном числе хозяйствующих субъектов, от которых зависит решение коррупционно значимых вопросов [1, с. 12-13].
Исследуемая проблема представляет научнопрактический интерес ввиду недостаточной изученности коррупционной преступности на уровне агломераций (городских агломераций), особенностей ее проявления и детерминации. В этой связи криминологический интерес могут представлять сложившиеся на территории Республики Татарстан агломерации: Казанская, Камская и Альметьевская, имеющие разноплановые особенности, которые могут влиять на детерминацию и проявления коррупционной преступности.

\section{Исследование отдельных показателей (признаков) регистрируемой коррупционной преступности в агломерациях Республики Татарстан}

В Республике Татарстан на сегодняшний день экономически и географически сложились три крупнейшие агломерации - Казанская, Камская и Альметьевская,

\footnotetext{
Ахунов Денис Робертович, преподаватель кафедры уголовного процесса Казанского юридического института МВД России, г. Казань, Российская Федерация. E-mail: rutadena@yandex.ru
} 
которые получили нормативно-правовое закрепление как на региональном², так и федеральном³ уровнях. Данные агломерации имеют разноплановые особенности, перспективы и векторы развития [5, с. 256-258]. Казанская и Камская агломерации отнесены к перечню федеральных центров экономического роста Российской Федерации ${ }^{4}$.

Наибольшей из указанных является Казанская агломерация общей численностью населения около 1,5 млн человек, которая расположена в северо-западной части Республики Татарстан. Агломерация является моноцентрической, представлена единым центром г. Казанью. Кроме того, в структуру и сферу влияния агломерации входят близлежащие населенные пункты Зеленодольского, Высокогорского, Пестречинского, Лаишевского, Верхнеуслонского муниципальных районов 5 .

Второй по величине и уровню развитию на территории Республики Татарстан является Камская агломерация с общей численностью населения более 900 тыс. человек, которая расположена в северо-восточной части республики. Агломерация является полицентрической, представлена рядом муниципальных образований городским округом Набережные Челны, выступающего основным ядром агломерации, городами Нижнекамск, Елабуга и Менделеевск, а также входящими в структуру и сферу влияния агломерации населенными пунктами Тукаевского, Нижнекамского, Елабужского и Менделеевского муниципальных районов ${ }^{6}$.

Наименьшей из трех является Альметьевская агломерация с общей численностью населения более 300 тыс. человек, которая находится в юго-восточной части республики. Агломерация является полицентрической, представлена рядом населенных пунктов - городами Альметьевск, Лениногорск и Бугульма, а также входящими в ее структуру и сферу влияния населенными пунктами одноименных муниципальных районов: Альметьевского, Лениногорского и Бугульминского ${ }^{7}$.

Ключевой особенностью значения всех трех агломераций выступают взаимосвязанные экономические комплексы производственного и инфраструктурного типов, которые составляют основу развития Республики Татарстан ${ }^{8}$.

Для исследования коррупциогенности указанных агломераций и влияния коррупционных проявлений в них на коррупционную преступность Республики Татарстан в целом автором проанализированы статистические данные [9, с. 117-118] информационного центра МВД по Республике Татарстан о зарегистрированных на

\footnotetext{
2 Стратегия социально-экономического развития Республики Татарстан до 2030 года: Закон Республики Татарстан от 17 июня 2015 года № 40-3РТ // Ведомости Государственного Совета Татарстана. 2015. № 6 (ч. II). Ст. 521. В дальнейшем в сносках: См.: Стратегия социально-экономического развития Республики Татарстан.

3 Распоряжение Правительства Российской Федерации от 13 февраля 2019 г. № 207-р «Об утверждении Стратегии пространственного развития Российской Федерации на период до 2025 года» // Собрание законодательства РФ. 2019. № 7 (ч. II). Ст. 702.

4 Там же.

5 См.: Стратегия социально-экономического развития Республики Татарстан.

6 Там же.

7 Там же.

8 Там же.
}

территории республики коррупционных преступлениях за период с 2018 г. по 2020 г.

\section{Состояние, динамика, коэффициент и удельный вес коррупционной преступности в агломерациях республики}

\section{Казанская агломерация}

Состояние коррупционной преступности определяется общим количеством зарегистрированных преступлений - в 2020 г. в Казанской агломерации зарегистрировано всего 506 коррупционных преступлений. Среднеарифметический показатель состояния за период с 2018 г. по 2020 год составил 432 преступлений. Всего за исследуемый период их зарегистрировано 1295.

Динамика состояния коррупционной преступности в исследуемом периоде стабильна, характеризуется повышением (табл. 1).

\section{Таблица 1}

Динамика коррупционной преступности в Казанской агломерации Республики Татарстан за период 2018-2020 г.

\begin{tabular}{|l|c|c|c|}
\hline Период & $\mathbf{2 0 1 8}$ г. & 2019 г. & $\mathbf{2 0 2 0}$ г. \\
\hline $\begin{array}{l}\text { Количество } \\
\text { зарегистрированных } \\
\text { преступлений }\end{array}$ & 329 & 460 & 506 \\
\hline
\end{tabular}

В целом с 2018 года по 2020 год абсолютный рост зарегистрированных коррупционных преступлений составил +177 преступлений (повышение в 1,54 раза).

Темп роста рассматриваемых преступлений в период 2019-2020 г. составляет 110\%, темп прироста - 10\%.

Коэффициент коррупционных преступлений в Казанской агломерации составляет $\approx 34$ преступления на 100000 населения:

$$
\mathrm{K}=\frac{506 \times 100000}{1478000^{9}}=34,23
$$

Удельный вес (C) коррупционных преступлений в Казанской агломерации в объеме всех коррупционных преступлений республики рассчитан по формуле, приведенной ниже (табл. 2):

$$
\mathrm{C}=\frac{\mathrm{u}}{\mathrm{U}} \times 100 \% \text {, }
$$

где $\mathrm{u}$ - показатель состояния (объема) отдельного типа, рода, вида или разновидности преступности; U - показатель объема всей преступности, вида преступлений на той же территории за тот же период времени.

Как следует из представленных в таблице данных, удельный вес коррупционных преступлений, зарегистрированных в Казанской агломерации, в общем объеме коррупционных преступлений Республики Татарстан в

\footnotetext{
См.: Стратегия социально-экономического развития Республики Татарстан
} 
Удельный вес коррупционных преступлений в Казанской агломерации в общем числе коррупиионных преступлений, зарегистрированных в Республике Татарстан за период 2018-2020 г.

\begin{tabular}{|c|c|c|c|}
\hline $\begin{array}{c}\text { Отчетный } \\
\text { период }\end{array}$ & $\begin{array}{c}\text { Число коррупционных } \\
\text { преступлений в } \\
\text { Казанской агломерации }\end{array}$ & $\begin{array}{c}\text { Общее число коррупционных } \\
\text { преступлений в Республики } \\
\text { Татарстан }\end{array}$ & $\begin{array}{c}\text { Удельный вес } \\
\text { коррупционных } \\
\text { преступлений, \% }\end{array}$ \\
\hline $\mathbf{2 0 1 8}$ г. & 329 & 832 & $39,5 \%$ \\
\hline $\mathbf{2 0 1 9}$ г. & 460 & 873 & $52,7 \%$ \\
\hline $\mathbf{2 0 2 0}$ г. & 506 & 1098 & $46,1 \%$ \\
\hline
\end{tabular}

исследуемом периоде значителен и варьируется от $39,5 \%$ в 2018 г. до 52,7\% в 2019 г., среднее значение - 46,1\%.

\section{Камская агломерация}

Состояние коррупционной преступности в Камской агломерации определяется тем, что в 2020 году зарегистрировано 175 таких преступлений. Среднеарифметический показатель состояния за период с 2018 г. по 2020 год - 184 преступления. Всего за исследуемый период их зарегистрировано 552.

Динамика состояния коррупционных преступлений в исследуемом периоде имеет нестабильный, положительный характер (табл. 3):

Таблица 3

Динамика коррупционных преступлений в Камской агломерации Республики Татарстан за период 2018-2020 г2.

\begin{tabular}{|l|c|c|c|}
\hline \multicolumn{1}{|c|}{ Период } & 2018 г. & 2019 г. & 2020 г. \\
\hline $\begin{array}{l}\text { Количество } \\
\text { зарегистрированных } \\
\text { преступлений }\end{array}$ & 226 & 151 & 175 \\
\hline
\end{tabular}

В период 2018-2020 гг. абсолютный рост зарегистрированных преступлений составил +24 преступления (повышение в 1,16 раза). Абсолютное снижение зарегистрировано с 2018 года по 2019 г. и составило 75 преступлений (снижение в 1,5 раза).

Темп роста рассматриваемых преступлений в период 2019-2020 г. составляет 115,9\%, темп - прироста $15,9 \%$. Темп снижения преступлений в период с 2018 года по 2019 год составляет 66,9\%, а темп прироста - 33,2\%.

Коэффициент коррупционных преступлений в Камской агломерации составляет $\approx 18$ преступлений на 100000 населения:

$$
\mathrm{K}=
$$$$
944300^{10}
$$

10 См.: Стратегия социально-экономического развития Республики Татарстан.
Удельный вес (С) коррупционных преступлений Камской агломерации в объеме всех зарегистрированных коррупционных преступлений Республики Татарстан представлен ниже (табл. 4).

Как следует из представленных в таблице данных, в исследуемом периоде удельный вес коррупционных преступлений, зарегистрированных в Камской агломерации, в общем объеме коррупционных преступлений республики сравнительно значителен. Его показатели в период 2018-2020 г. варьируются от 15,9\% (в 2020 г.) до $27,7 \%$ (в 2018 г.), среднее значение составляет 20,3\%. Изменение динамики удельного веса в целом носит отрицательный характер.

\section{Альметьевская агломерация}

Состояние коррупционной преступности определяется тем, что в 2020 году зарегистрировано 110 преступлений. Среднеарифметический показатель состояния в исследуемом периоде составляет 95 преступлений. Всего за исследуемый период зарегистрировано 287 преступлений.

Динамика состояния коррупционной преступности в исследуемом периоде нестабильна, имеет тенденцию к увеличению (табл. 5).

В период 2018-2020 г. абсолютный рост зарегистрированных преступлений составил +42 преступления (повышение в 1,6 раза). Абсолютное снижение зарегистрировано с 2018 года по 2019 г., составило 41 преступление (снижение в 1,6 раза).

Темп роста рассматриваемых преступлений в период 2019-2020 г. составляет 161,7\%, темп прироста $61,7 \%$. Темп снижения преступлений в период с 2018 года по 2019 год составляет 62,4\%, а темп прироста - 37,6\%.

Коэфбициент преступлений коррупционной направленности в Альметьевской агломерации за 2020 год составляет $\approx 32$ преступления на 100000 населения:

$$
K=\frac{110 \times 100000}{337000^{11}}=32,64
$$

Удельный вес (С) коррупционных преступлений Альметьевской агломерации в объеме всех коррупцион-

11 См.: Стратегия социально-экономического развития Республики
Татарстан. 
Удельный вес коррупиионных преступлений в Камской агломерации в общем числе коррупиионных преступлений, зарегистрированных в Республике Татарстан за период 2018-2020 г2.

\begin{tabular}{|c|c|c|c|}
\hline $\begin{array}{c}\text { Отчетный } \\
\text { период }\end{array}$ & $\begin{array}{c}\text { Число преступлений } \\
\text { коррупцинной } \\
\text { направленности в Камской } \\
\text { агломерации }\end{array}$ & $\begin{array}{c}\text { Общее число преступлений } \\
\text { коррупцинной } \\
\text { направленности в Республики } \\
\text { Татарстан }\end{array}$ & $\begin{array}{c}\text { Удельный вес } \\
\text { преступлений } \\
\text { коррупционной } \\
\text { направленности, \% }\end{array}$ \\
\hline $\mathbf{2 0 1 8}$ г. & 226 & 832 & $27,7 \%$ \\
\hline $\mathbf{2 0 1 9}$ г. & 151 & 873 & $17,3 \%$ \\
\hline 2020 г. & 175 & 1098 & $15,9 \%$ \\
\hline
\end{tabular}

Динамика коррупиионной преступности в Альметьевской агломерации Республики Татарстан за период 2018-2020 г2.

\begin{tabular}{|l|c|c|c|}
\hline Период & $\mathbf{2 0 1 8}$ г. & 2019 г. & $\mathbf{2 0 2 0}$ г. \\
\hline $\begin{array}{l}\text { Количество } \\
\text { зарегистрированных } \\
\text { преступлений }\end{array}$ & 109 & 68 & 110 \\
\hline
\end{tabular}

Удельный вес коррупиионных преступлений в Альметьевской агломерации в общем числе коррупционных преступлений, зарегистрированных в Республике Татарстан за период 2018-2020 г.

\begin{tabular}{|l|c|c|c|}
\hline $\begin{array}{c}\text { Отчетный } \\
\text { период }\end{array}$ & $\begin{array}{c}\text { Число преступлений } \\
\text { коррупцинной } \\
\text { направленности в } \\
\text { Альметьевской агломерации }\end{array}$ & $\begin{array}{c}\text { Общее число преступлений } \\
\text { коррупциноой направленности } \\
\text { в Республики Татарстан }\end{array}$ & $\begin{array}{c}\text { Удельный вес } \\
\text { преступлений } \\
\text { коррупционной } \\
\text { направленности, \% }\end{array}$ \\
\hline $\mathbf{2 0 1 8}$ г. & 109 & 832 & $13,1 \%$ \\
\hline $\mathbf{2 0 1 9}$ г. & 68 & 873 & $7,8 \%$ \\
\hline $\mathbf{2 0 2 0}$ г. & 110 & 1098 & $10,1 \%$ \\
\hline
\end{tabular}

ных преступлений Республики Татарстан представлен выше (табл. 6).

Как следует из представленных в таблице данных, в период 2018-2020 г. удельный вес коррупционных преступлений, зарегистрированных в Альметьевской агломерации, в общем объеме коррупционных преступлений Республики Татарстан сравнительно значителен. Его показатели в рассматриваемый период варьируются от 7,8\% (в 2019 г.) до 13,1\% (в 2018 г.), среднее значение 10,3\%. Изменение динамики удельного веса в целом носит отрицательный характер.

\section{Выводы}

Состояние, динамика, коэффициент и удельный вес коррупционных преступлений в Казанской, Камской и Альметьевской агломерациях Республики Татар- стан позволил выявить следующие особенности их проявлений.

Уровень преступлений коррупционной направленности выше в наиболее крупных агломерациях: в Казанской - среднеарифметический показатель состояния: 432 преступления, всего зарегистрировано 1295 преступлений; в Камской - среднеарифметический показатель состояния: 184 преступления, всего зарегистрировано 552 преступления; в Альметьевской - среднеарифметический показатель состояния: 95 преступлений, всего зарегистрировано 287 преступлений.

Удельный вес преступлений коррупционной направленности, зарегистрированных в агломерациях, значителен в общем числе таковых Республики Татарстан. В исследуемом периоде на агломерации в совокупности приходится от 72,1\% до 79,8\% всех зарегистрированных в регионе коррупционных преступлений. 
Проведенный криминологический анализ показателей коррупционной преступности в агломерациях в исследуемом периоде указывает на то, что данные системы расселения консолидируют в себе подавляющее большинство регистрируемой коррупционной преступности в регионе. Кроме того, в исследуемом периоде усматривается корреляция между размерами и уровнем развития агломераций и количеством регистрируемых коррупционных преступлений в них. Это позволяет сделать вывод, что на состояние коррупционной преступности в агломерациях влияет их размер, обусловленный экономическим развитием, и, соответственно, «оттягивание» ресурсов в более крупные агломерации. Данные обстоятельства указывают на то, что одними из ключевых детерминант коррупционной преступности в агломерациях являются социальноэкономические детерминанты, в частности, концентрация ресурсов в центрах агломераций, что вызывает высокую дифференциацию в доходах различных групп населения Республики Татарстан ${ }^{12}$ и возможностях удовлетворения их потребностей. Отдельно в числе экономических детерминант следует отметить значительные масштабы теневой экономики как основного источника коррупционной ренты.

Помимо экономических, отдельно следует выделить правовые детерминанты коррупционной преступности в исследуемых территориальных образованиях. Основная особенность их проявления заключается в неурегулированности на федеральном законодательном уровне правового положения данных территориальных образований, а также вопросов межмуниципальных вза- имоотношений внутри них. Отсутствие должного правового регулирования правоотношений, возникающих в связи с деятельностью и функционированием городских агломераций, влечет возникновение и развитие внутри них властных неформальных управленческих связей, которые формируют «невидимые» административные горизонтальные и вертикальные связи, выступающие самостоятельным фактором коррупциогенности территории.

Полученные результаты исследования указывают на потребность в исследовании коррупционных преступлений в агломерациях как сложных, социально-экономических системах расселения, а также необходимость выработки эффективных мер предупреждения преступности [8] в этих территориальных образованиях, заметно ухудшающих криминогенную обстановку в России и ее отдельных регионах.

Ключевой мерой предупреждения коррупционной преступности в городских агломерациях Российской Федерации на первоначальном этапе видится принятие федерального закона, который должен установить законодательное определение городской агломерации, основные принципы формирования и функционирования таких систем расселения населения, их управленческие органы, права и обязанности входящих в их состав субъектов. Правовая легализация рассматриваемых территориальных образований позволит в дальнейшем регулировать отношения, складывающиеся в связи с функционированием городских агломераций, в том числе социально-экономические процессы, и, как следствие, влиять на детерминанты коррупционной преступности в данных территориальных системах.

\section{Литература}

1. Алишаев Э.А. Трансформация системы коррупционных отношений в экономике рыночной ориентации : автореф. ... канд. экон. наук. М., 2011. $32 \mathrm{c}$.

2. Шегабудинов Р.Р. Признаки, определяющие однородность и различия экономической преступности, коррупции и организованной преступности в Российской Федерации // Образование и право. 2021. № 1. С. 120-127.

3. Мусинова Н.Н. Социально-экономическое развитие муниципальных образований в рамках городских агломераций // Вестник ГУу. 2021. № 5. C. 5-11.

4. Даштиева М.Э. Влияние агломерационных процессов на пространственную поляризацию развития экономики страны // Новые импульсы развития: вопросы научных исследований. 2021. № 4. С. 104-107.

5. Пигарь Н.Ю. Перспективы развития Казанской агломерации // АНИ: экономика и управление. 2019. № 1 (26). С. 256-258.

6. Чжан Цзе. Проблемы урбанизации в современном Китае и направления их решения // Социология. 2021. № 3. С. 46-52.

7. Лаппо Г. Н., Полян П. М. Результаты урбанизации в России к концу ХХ века // Мир России. Социология. Этнология. 1999. № 4. С. 35-46.

8. Плохова В.И. Роль криминологических исследований в совершенствовании уголовного права // Всероссийский криминологический журнал. 2011. № 3. С. 5-12.

9. Афанасьев В.Н., Леушина Т.В., Романов С.Р. Обобщающие показатели в статистике российской преступности // Вестник НГУЭУ. 2020. № 2. С. $117-126$.

10. Галиновская Е.А., Кичигин Н.В. Городская агломерация как правовая категория: постановка проблемы // Журнал российского права. 2020. № 8. С. $141-156$.

12 См.: Стратегия социально-экономического развития Республики Татарстан. 


\section{Certain features Characterising Corruption Crime in URban areas (USING DATA FROM THE RePUblic Of TATARSTAN)}

\section{Akhunov ${ }^{13}$}

Keywords: corruption, corruption crimes, criminological characteristics of crimes, crime indicators, urban area, urban agglomeration.

\section{Abstract.}

Purpose of the work: analysing individual indicators (state, dynamics and proportion) of corruption crime registered in the territory of urban areas of the Republic of Tatarstan characterising the corruptogenicity of these population settlement systems.

Methods of study: logical, system structure, mathematical and statistical methods.

Results of study: a criminological analysis of certain indicators (features) of registered corruption crime in urban areas of the Republic of Tatarstan for the period of 2018 to 2020 made it possible to draw a number of conclusions. First, the results of the study indicate an increased corruptogenicity of urban areas. Second, a correlation between the size and development level of these population settlement systems and corruption crime level there is determined. Third, the vast majority of registered corruption offences in the territories are concentrated in urban areas which indicates a need to study the determination and features of criminal manifestations of corruption in this regional aspect. Fourth, it is necessary to develop efficient measures for combating corruption crimes in the considered territories which significantly worsen the criminal situation in Russia at large and its individual regions.

\section{References}

1. Alishaev E.A. Transformatsiia sistemy korruptsionnykh otnoshenii v ekonomike rynochnoi orientatsii : avtoref. ... kand. ekon. nauk. M., 2011. $32 \mathrm{pp}$.

2. Shegabudinov R.R. Priznaki, opredeliaiushchie odnorodnost' i razlichiia ekonomicheskoi prestupnosti, korruptsii i organizovannoi prestupnosti v Rossiiskoi Federatsii. Obrazovanie i pravo, 2021, No. 1, pp. 120-127.

3. Musinova N.N. Sotsial'no-ekonomicheskoe razvitie munitsipalnykh obrazovanii v ramkakh gorodskikh aglomeratsii. Vestnik GUU, 2021, No. 5, pp. 5-11.

4. Dashtieva M.E. Vliianie aglomeratsionnykh protsessov na prostranstvennuiu poliarizatsiiu razvitiia ekonomiki strany. Novye impul'sy razvitiia: voprosy nauchnykh issledovanii, 2021, No. 4, pp. 104-107.

5. Pigar' N.Iu. Perspektivy razvitiia Kazanskoi aglomeratsii. ANI: ekonomika i upravlenie, 2019, No. 1 (26), pp. 256-258.

6. Chzhan Cze. Problemy urbanizatsii v sovremennom Kitae i napravleniia ikh resheniia. Sotsiologiia, 2021, No. 3, pp. 46-52.

7. Lappo G. N., Polian P. M. Rezul'taty urbanizatsii v Rossii k kontsu XX veka. Mir Rossii. Sotsiologiia. Etnologiia. 1999, No. 4, pp. 35-46.

8. Plokhova V.I. Rol' kriminologicheskikh issledovanii $\mathrm{v}$ sovershenstvovanii ugolovnogo prava. Vserossiiskii kriminologicheskii zhurnal, 2011, No. 3, pp. 5-12.

9. Afanas'ev V.N., Leushina T.V., Romanov S.R. Obobshchaiushchie pokazateli v statistike rossiiskoi prestupnosti. Vestnik NGUEU, 2020, No. 2, pp. 117-126.

10. Galinovskaia E.A., Kichigin N.V. Gorodskaia aglomeratsiia kak pravovaia kategoriia: postanovka problemy. Zhurnal rossiiskogo prava, 2020, No. 8, pp. 141-156.

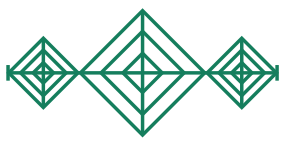

13 Denis Akhunov, lecturer at the Department of Criminal Procedure of Kazan Law Institute of the Ministry of Internal Affairs of Russia, Kazan, Russian Federation. E-mail: rutadena@yandex.ru 


\section{ЗНАЧЕНИЕ ДОКАЗАТЕЛЬСТВ В ТЕОРИИ УГОЛОВНО-ПРОЦЕССУАЛЬНОГО ДОКАЗЫВАНИЯ: ПРОБЛЕМЫ И ПУТИ ИХ РЕШЕНИЯ}

Гарипов Т. И. ${ }^{1}$

Ключевые слова: доказательственное право, допустимость доказательств, показания свидетеля, заключение эксперта, возбуждение уголовного дела, предварительное расследование, внутреннее убеждение, усмотрение правоприменителя.

\section{Аннотация.}

Цель работы: рассмотрение наиболее проблемных аспектов понятия доказательств в теории уголовно-процессуального доказывания современного отечественного уголовного судопроизводства.

Методы исследования: современные диалектические методы изучения государственно-правовой действительности. Среди методов можно выделить анализ, синтез, ретроспективный анализ, сравнительно-правовой метод.

Результаты исследования: был сформулирован вывод о существенной роли доказательств и доказывании в разрешении уголовного дела по существу, а также о необходимости пересмотра подходов в определении понятия и свойств доказательств. Современный институт доказательств нуждается в дальнейшем теоретическом осмыслении с учетом постоянно меняющейся государственно-правовой действительности. Но какими бы процессуальными формами ни обладали доказательства в уголовном судопроизводстве, их основным предназначением должно оставаться установление существенных обстоятельств уголовного дела в целях изобличения лица, совершившего преступление, справедливого разрешения дела по существу и защиты личности от необоснованного, незаконного обвинения и нарушения прав и свобод человека и гражданина.

DOI: 10.21681/2226-0692-2021-4-74-81

древнейших времен, когда государственные и правовые институты только проходили этап своего становления, для признания лица виновным в совершении того или иного преступления требовалось нечто более весомое, чем просто заявление пострадавшего лица перед государственными чиновниками, полномочными рассматривать уголовные иски и назначать уголовное наказание. Для определения виновности лица в совершении преступления римскими юристами была разработана система, позволившая с точностью, на основании внутреннего убеждения судьи или лица, рассматривавшего уголовное дело, определять, причастно ли лицо к совершению конкретного преступления и виновно ли оно в его совершении. Данный правовой институт получил название системы доказательств в уголовном судопроизводстве.

Прошло достаточное долгое время эволюции понятия, системы и содержания доказательств в уголовном судопроизводстве. В первоначальный период своего существования институт доказательств носил весьма условный характер, поскольку его применение было обусловлено теми государственно-общественными формациями и противоречиями, возникающими в резуль- тате отношения различных классов к праву собственности на средства производства. Так, например, в Древнем Риме показания, данные рабом в уголовном судопроизводстве, не считались доказательством, поскольку такие лица на тот момент по определению не могли выступать в качестве самостоятельного участника правоотношений в силу того, что рабы выступали скорее в качестве объекта имущественных прав, нежели отдельных субъектов права. Со временем подобные ограничения в качестве использования тех или иных видов доказательств стали распространяться на крепостное крестьянство и иных лиц низших сословий в государствах Европы периода средневековья. Значительного прогресса в достижении развития понятия и системы уголовно-процессуальных доказательств удалось достичь в результате коренных преобразований, произошедших во французском обществе после Великой французской буржуазной революции. Это событие определило дальнейший ход не только мировой истории, но и отдельных институтов права. Впервые в период становления правосудия и уголовной юстиции после Французской революции были сняты сословные ограничения в части определения доказательственного значения тех или иных видов

\footnotetext{
Гарипов Тимур Ильгизович, кандидат юридических наук, старший преподаватель кафедры уголовного процесса Казанского юридического института МВД России, г. Казань, Российская Федерация. E-mail: ti89ga@mail.ru
} 
доказательств. Дальнейшее развитие уголовно-процессуального законодательства во многом было определено идеями, родившимися в горниле Французской революции и прошедшими апробацию как через значительные уголовные репрессии, так и через труды великих французских мыслителей-гуманистов. Такая коллаборация привнесла значительные достижения, ставшие впоследствии неотъемлемой частью мировой уголовно-процессуальной теории, а идеи, воплотившиеся в этой теории, были рецептированы многочисленными странами в собственной национальной системе уголовно-процессуального законодательства [1].

Одной из таких универсальных идей стала идея формального равенства доказательств при оценке их судьей, следователем или прокурором. Данная идея, как сказали бы ученые-процессуалисты советского периода, являет собой продукт буржуазной уголовно-процессуальной мысли, ставшей продуктом череды великих европейских революций в период распада монархической системы правления. Однако и советское законодательство, пропитанное идеологическими концепциями марксизма-ленинизма, не побрезговало заимствовать эти несомненно прогрессивные идеи в свой собственный арсенал системы уголовно-процессуальных принципов и гарантий.

Так, говоря об отсутствии у доказательств заранее установленной силы, следует в первую очередь иметь в виду их формальное равенство перед законом и убеждением должностного лица, осуществляющего их оценку. Нет доказательств ни худших, ни лучших для установления обстоятельств, подлежащих установлению по уголовному делу. Например, одни и те же доказательства, полученные аналогичным способом, путем производства одного и того же следственного действия, в которых содержатся фактические данные об одних и тех же обстоятельствах уголовного дела, но полученные от разных по своему социальному и имущественному положению лиц (например, данные, содержащиеся в показаниях, полученных от подозреваемого или потерпевших), должны рассматриваться как равнозначные по своей юридической силе, безотносительно к каким-либо признакам, не имеющим юридического значения.

Так, например, если известный в городе $\mathrm{N}$ предприниматель, меценат и депутат местного (регионального) представительного органа государственной власти (или его близкий родственник), вдруг по случайному стечению обстоятельств совершает преступление, предусмотренное ст. 264 Уголовного кодекса (УК) РФ, то есть, нарушив правила дорожного движения, управляя своим автомобилем с превышением установленной скорости в состоянии алкогольного опьянения, совершает ДТП, сбивая человека, который оказывается лицом без постоянного места жительства и причиняет ему таким образом тяжкий вред здоровью, - то он должен быть допрошен в любом случае в качестве подозреваемого по уголовному делу, но не в качестве случайного свидетеля, если, конечно, доподлинно установлено, что именно он управлял данным транспортным средством. В свою очередь, потерпевший по подобному уголовному делу допрашивается, и его показания должны быть получены таким образом, чтобы всячески исключить их двусмысленное толкование с целью убеждения правопримени- теля в виновности самого потерпевшего в случившемся ДТП. Однако такой подход при определении равнозначности и отсутствия заранее установленной силы данных доказательств должен быть, несомненно, обеспечен совокупностью иных доказательств, собранных в результате следственных действий по данному уголовному делу, например, протокола осмотра места происшествия, заключения экспертов и специалистов. Сто́ит при этом упомянуть, что хотя показания подозреваемого - депутата (или его близкого родственника) - и показания потерпевшего - лица без определенного места жительства - формально равны, но, как это нередко бывает в российской правовой действительности, должностными лицами допускается искажение доказательств, которые подтверждают виновность водителя автомобиля в совершении преступления, путем искажения фактических данных протокола осмотра места происшествия (в части измерения длины тормозного пути, характера повреждений автомобиля и т. д.), которые впоследствии отразились бы на содержании заключения автотехнического эксперта в части несоответствия выводов эксперта фактическим обстоятельства произошедшего события. Таким образом, фактически потерпевший лишается права на доступ к правосудию в результате не только того, что показания, данные им по уголовному делу, были оценены в качестве доказательств, имеющих меньшую (или даже ничтожную) юридическую силу, но и комплексного, цельного подхода к самой сути правосудия как сословному элементу нашего современного российского общества. В результате фактически виновное в совершении преступления лицо - бизнесмен, способствующий развитию конкретного региона (он же предприниматель - собственник крупных предприятий, т. е. средств производства) - избегает уголовной ответственности ввиду неустановления правоохранительными органами признаков какого-либо состава преступления в его действиях. Мало того, в результате такого решения правоохранительных органов лицо, которому фактически причинен вред здоровью, лишается права на возмещение данного вреда путем имущественных взысканий от виновного лица, поскольку оно фактически не установлено.

Несмотря на то, что нами приведен условный пример из повседневной жизни вымышленного российского города, любой неискушенный читатель найдет в данной ситуации знакомые черты объективной правовой действительности своего собственного города или поселка. Это то, с чем обычный обыватель может столкнуться ежедневно, проходя по своей знакомой с детства улице на работу, учебы, провожая своего ребенка в детский сад или школу. Такова наша жизнь на сегодня, и за примерами из реальной жизни далеко ходить нет необходимости ${ }^{2}$.

При чем же здесь вопросы содержания уголовно-процессуальных доказательств? Мы ответим, что подобный подход в определении содержания тех или иных доказательств складывается в результате полного игнорирования такого принципа уголовного процесса, как свобода оценки доказательств, изложенного в ст. 17 Уголовно-процессуального кодекса (УПК) РФ.

\footnotetext{
Смертельный наезд по крайней необходимости. URL: https:// www.gazeta.ru/auto/2014/09/29a624130.shtml (дата обращения: 18.10.2021).
} 
Тенденции современной российской государственно-правовой действительности в части правоприменения отдельных институтов уголовно-процессуального закона, в том числе институтов доказательственного права, вызывают обоснованное беспокойство [2]. Подобная система закладывает мину замедленного действия под фундамент нашего правосудия и общества в целом. Если не предпринимать радикальных мер по искоренению подобных проблем российской уголовной юстиции, то это чревато крупными и значительными социальными потрясениями, которые лягут на плечи обычных граждан нашей страны, повлекут за собой в водовороте переворотов, революций и войн значительные жертвы, через которые Россия уже проходила на предыдущих этапах своего развития.

Практика, сложившаяся в результате применения норм УПК РФ о сборе, проверке доказательств и оценке их содержания, страдает тяжкой болезнью, именуемой политизацией уголовного процесса и фактическим рассмотрением уголовно-процессуальных институтов в качестве орудия, продолжающего или воплощающего в жизнь интересы отдельных элитных групп или конкретных влиятельных личностей.

Содержание доказательств должно оцениваться с позиций их равенства, и ни в коем случае не допускается их деление на лучшие или худшие в зависимости от того, из каких источников они были получены, или иных обстоятельств, обусловленных условиями их получения [3].

Так, в качестве примера следует отметить значение такого вида доказательства, как заключение эксперта, которое представляет собой определенное суждение, сформулированное благодаря исследованию, проведенному им в области конкретных научных познаний, в части разрешения вопросов, которые были поставлены перед ним следователем [4]. Мы понимаем, что заключение эксперта ввиду того, что оно обосновано последними достижениями научной и технической мысли, вероятнее всего, носит достоверный характер. Однако стоит помнить, что как бы ни был высок авторитет эксперта, сформулировавшего данное заключение, его следует оценивать с позиций иных доказательств, полученных в ходе производства по конкретному уголовному делу, безотносительно к тому, противоречат ли они выводам эксперта, данным им в заключении, или нет. При этом стоит также отметить, что заключение эксперта не является для следователя или дознавателя обязательным в части юридического установления каких-либо обстоятельств уголовного дела, поскольку его итоговая оценка обусловлена внутренним убеждением самого судьи или следователя, однако при несогласии с выводами заключения эксперта должностное лицо обязано изложить собственные доводы несогласия с такими выводами и отразить данные доводы в тексте описательной части обвинительного заключения, обвинительного акта или приговора в контексте анализа доказательств собранных по уголовному делу либо назначить производство новой повторной судебной экспертизы, поставив аналогичные вопросы перед другим экспертом в той же самой сфере научных познаний.

Еще одним характерным признаком, характеризующим значение доказательств в теории уголовно-про- цессуального права, является вопрос о субъективной оценке их содержания должностным лицом, осуществляющим расследование по уголовному делу, или судом. Уголовно-процессуальный закон в данном случае для определения содержания мыслительной, интеллектуальной деятельности следователя или суда использует такие общефилософские и нравственные категории, как внутреннее убеждение и совесть.

Говоря о внутреннем убеждении как категории, относящейся непосредственно к оценке полученных в ходе производства по уголовному делу доказательств, следует отметить, что оно обусловлено теми субъективными признаками и индивидуальными особенностями, которые характеризуют личность конкретного правоприменителя, проводящего оценку доказательств по конкретному уголовному делу. Так, нравственные основы, заложенные в самом человеке - должностном лице, принимающем процессуальное решение по уголовному делу, могут существенно повлиять на то, как он оценит то или иное доказательство и какое процессуальное решение по данному поводу примет в итоге.

Внутреннее убеждение суда, следователя, прокурора при оценке доказательств есть категория неосязаемая, невосприимчивая к органам чувств и интеллектуальной деятельности стороннего наблюдателя, любого другого участника уголовного процесса. Внутреннее убеждение правоприменителя формируется в ходе всего производства по уголовному делу, начиная со стадии возбуждения уголовного дела и заканчивая такими экстраординарными этапами уголовного судопроизводства, как производство по новым или вновь открывшимся обстоятельствам. Процесс формирования внутреннего убеждения сопряжен с мыслительной, интеллектуальной деятельностью, направленной на анализ содержания собранных по уголовному делу доказательства. Однако ни в юридической литературе, ни в каком-либо нормативном правовом акте или разъяснениях Верховного суда РФ не указано количество собранных и проанализированных доказательств по уголовному делу, достаточных для формирования внутреннего убеждения с целью принятия законного, обоснованного и справедливого решения по уголовному делу. Внутреннее убеждение при оценке доказательств должностным лицом формируется вне зависимости от каких-либо научно обоснованных рекомендаций или ведомственных нормативных положений. Каждый правоприменитель проводит сквозь свое сознание содержание проанализированных доказательств и принимает решение сообразно с сформировавшимся в себе убеждением относительно фактов, установленных в ходе производства по уголовному делу и существенным образом влияющих на принятие зачастую итогового процессуального решения $[5]$.

Внутреннее убеждение следователя, суда или прокурора также, согласно УПК РФ, соотносится с понятием совести, которое встречается в тексте закона, предусмотренном ст. 17 УПК РФ. Совесть, как и внутреннее убеждение, представляет собой исключительно субъективное и оценочное понятие, которое характеризует морально-нравственную сторону личности правоприменителя. Совесть как философская категория пред- 
ставляет собой внутренние психологические установки личности, сформировавшиеся в ней в результате социализации, то есть в ходе ее становления, приобщения к социальным и нравственным нормам и нормативам, принятым в конкретном обществе. Совесть служит своего рода способом самоконтроля поведения личности [6]. В обывательском сознании существует устоявшееся выражение «переступить через совесть», что фактически означает факт нарушения человеком собственных установок с последующими психологическими последствиями для человека, совершившего тот или иной поступок и внутренними психологическими переживаниями лицами, происходящими по поводу данных обстоятельств. Поступить вопреки собственной совести или не допустить поступка, который бы позволил это сделать, - этот вопрос решается каждым человеком индивидуально и на его решение вряд ли кто-либо может повлиять существенным образом. Как правило, подобные решения принимаются в так называемых ситуациях морального выбора, когда перед человеком стоит вопрос о выборе своего поведения или принятия решения, в результате которого это поведение или решение может вступить в конфликт с собственной совестью.

Так, следователь сам решает, следует ли привлекать в качестве обвиняемого по уголовного делу лицо, если в отношении него собрано недостаточное, по его мнению, количество доказательств, либо если данные доказательства противоречивы. Конечно же, на решение следователя может влиять не только его собственная совесть и внутреннее убеждение, но и еще такие внешние факторы, как требования ведомственных показателей служебной деятельности за определенный период времени, именуемые в обиходе «палочной системой», которая, несмотря на проведенные на рубеже десятилетий в России реформы в правоохранительных органах (в первую очередь в ОВД и Следственном комитете РФ), продолжает оставаться и влияет на многие процессуальные решения, принимаемые ежедневно следователями и дознавателями правоохранительных ведомств на различных уровнях (местном, региональном, федеральном). Эта «палочная система» сводит на нет любые попытки законодателя закрепить демократические и гуманистические основы уголовного судопроизводства в ежедневной деятельности правоохранительных органов по выявлению, раскрытию и расследованию преступлений в России. В связи с этим, хотя формально уголовно-процессуальный закон и предписывает следователю или суду руководствоваться собственной совестью при оценке доказательств, на деле же их совесть попирается элементарными прагматическими соображениями, ведомственными интересами о достижении неимоверных высот их деятельности, выразившимся в увеличении или уменьшении статистических показателей относительно аналогичного периода прошлого года, о чем докладывается высшим лицам государства на очередной расширенной коллегии того или иного правоохранительного ведомства.

Значение доказательств в уголовно-процессуальной деятельности следователя, дознавателя или суда трудно переоценить. По сути, весь уголовный процесс так или иначе строится на сборе и анализе собранных доказательств и дальнейшем их использовании в ходе процессуального поединка между сторонами обвинения или защиты. Для каждого конкретного участника уголовного процесса, в зависимости от принадлежности его к той или иной стороне (обвинения, защиты или суда), каждое собранное по уголовному делу доказательство будет иметь собственное значение.

Так, для стороны обвинения, осуществляющей уголовное преследование по уголовному делу, связанное с необходимостью раскрытия преступления и изобличения лица, совершившего преступление, доказательства будут иметь значение в контексте установления всех обстоятельств, подлежащих доказыванию по уголовному делу, необходимости сбора достаточной их совокупности для принятия решения о привлечении лица в качестве обвиняемого и предъявлении обвинения, а впоследствии сбора достаточных доказательств для окончания расследования, составления обвинительного заключения (акта) и направления уголовного дела вместе с обвинительным заключением (актом) прокурору для последующего утверждения и направления уголовного дела в суд для рассмотрения его по существу. Для прокурора, который будет в суде выступать в качестве государственного обвинителя, поддерживая государственное обвинение, доказательства будут иметь значение инструментов, с помощью которых он сможет сформировать у суда убеждение о причастности подсудимого ко вменяемым ему в вину преступлениям или его виновности в их совершении. Апеллируя собранными доказательствами, прокурор в судебном следствии сможет умело парировать доводы защиты относительно позиций, которых придерживается подсудимый и его защитник.

Для стороны защиты доказательства, собранные по уголовному делу, имеют собственное юридическое значение, проявляющееся в наличии процессуальных возможностей повлиять на принимаемые решения и на итоговый исход по уголовному делу. Так, показания обвиняемого, которые даны им после консультации с защитником, в ходе которой ими совместно была выработана единая позиция защиты относительно содержания предъявленного обвинения, могут быть использованы на досудебных стадиях уголовного судопроизводства, например, при заявлении соответствующих ходатайств о прекращении уголовного дела или уголовного преследования или о производстве дополнительных следственных действий, которые могли бы проверить подлинность показаний обвиняемого или опровергнуть доказательства, представленные обвиняемому стороной обвинения в ходе его допроса. И даже в тех случаях, когда обвиняемый в своих показаниях признается в совершении преступления и искренне раскаивается в его совершении, доказательственное их значение для стороны защиты тоже будет иметь определенный смысл, поскольку в дальнейшем сторона защиты вправе сослаться на эти показания как подтверждающие факт деятельного раскаяния обвиняемого, что в конечном итоге может повлиять на строгость приговора, поскольку данное обстоятельство выступает в качестве смягчающего при назначении судом уголовного наказания.

Для суда, единственной процессуальной функцией которого является необходимость разрешения уголовного дела по существу, представленные сторонами 
доказательства имеют значение для разрешения ключевых вопросов по уголовному делу: о виновности или невиновности подсудимого, причастности или непричастности его к преступлению. С помощью доказательств суд устанавливает обоснованность предъявленного подсудимому обвинения в части уголовно-правовой квалификации содеянного, количества совершенных подсудимым эпизодов преступной деятельности, а также иных вопросов, связанных с постановлением приговора: о возмещении причиненного преступлением вреда, о конфискации имущества, добытого преступным путем, о процессуальных издержках и т. д.

На этапе возбуждения уголовного дела значение уголовно-процессуальных доказательств не столь очевидно, как это может показаться на первый взгляд. Известно, что данная стадия характеризуется непроцессуальным характером действий, осуществляемых следователем и органом дознания в целях приема, регистрации, проверки и разрешения сообщений о преступлениях, что накладывает на нее определенный ограничительный отпечаток в плане процессуальных возможностей по сбору и проверке доказательства. Недаром в соответствии со ст. 140 УПК РФ в качестве основания для возбуждения уголовного дела выступают достаточные данные, указывающие на признаки преступления. Обратим внимание на формулировку, которую использует законодатель. Речь идет не о достаточных доказательствах, а лишь достаточных данных, указывающих на признаки преступления. Таким образом, эти данные, исходя из буквального толкования вышеуказанной нормы, не облечены в установленную процессуальную форму доказательств и доказательствами как таковыми могут и не являться. Однако, несмотря на это, действующий УПК РФ в нормах, регламентирующих стадию возбуждения уголовного дела, указывает на возможность сбора доказательств и до начала официальной процессуальной деятельности. Отметим также, что доказательства, собранные на данном этапе, также будут иметь равное значение с иными материалами проверки, в том числе и с результатами оперативно-розыскной деятельности, даже более того - эти доказательства будут оставаться таковыми и уже после возбуждения уголовного дела как на предварительном расследовании, так и на судебном разбирательстве, где суд также может обращаться к их содержанию для установления обстоятельств, имеющих существенное значение для разрешения уголовного дела.

Так, в ст. 144 УПК РФ содержится примерный перечень способов проверки сообщения о преступлении, в котором определенное место занимают следственные и иные процессуальные действия: следственный осмотр, освидетельствование, назначение и производство судебной экспертизы, истребование документов, производство исследования. Таким образом, уголовно-процессуальный закон допускает получение на этапе возбуждения уголовного дела таких доказательств как протокол осмотра и освидетельствования, заключение эксперта и специалиста, а также иных документов.

Следует отметить, что доказательства, полученные на этапе проверки сообщения о преступлении, также могут быть положены в основание для принятия решения о возбуждении уголовного дела, - например, протокол осмотра места происшествия, содержанием которого является обстановка, зафиксированная на месте совершения кражи с незаконным проникновением в жилище, фиксирующий способы проникновения в квартиру, например, взлом входной двери, подбор ключей и т. д., в общем и целом сведения, отражающие необходимые признаки конкретного состава преступления для принятия решения о квалификации при возбуждении уголовного дела. В качестве примера можно также привести содержание протокола места происшествия при убийстве, в котором содержатся сведения о насильственном характере смерти при описании повреждений на теле потерпевшего лица. В иных случаях содержание заключения эксперта будет иметь основополагающее значение для принятия решения о возбуждении уголовного дела; в нем будет установлено, например, что внезапная остановка сердца потерпевшего вызвана не наличием у него хронического заболевания, а принятие смертельной дозы сильного отравляющего вещества. Решающую роль заключение эксперта играет также в ходе доследственной проверки по сообщению о преступлении, предусмотренному ст. 228 УК РФ и предусматривающему уголовную ответственность за незаконное хранение наркотических средств, в части установления вида и размера признанного наркотическим вещества, изъятого в результате обыска или досмотра. Данные сведения, облеченные в форму уголовно-процессуального доказательства - заключения эксперта - существенным образом могут отразиться на квалификации содеянного виновным при возбуждении уголовного дела.

Однако отметим, что в последнее время в законодательстве намечается тенденция на установление доказательственного тождества между данными, полученными в ходе доследственной проверки, и доказательствами, полученными при производстве следственных действий. Так, с добавлением в УПК РФ главы 32.1 о производстве дознания в сокращенной форме законодатель допустил возможность использовать в качестве доказательств по уголовному делу сведения, полученные в ходе проверки сообщения, если достоверность данных сведений не оспаривается стороной защиты и она не ходатайствует об установлении обстоятельств, имеющих значение для уголовного дела, следственным путем. В рамках этих изменений в ст. 144 УПК РФ был также добавлен п. 1.2, которым тоже предусмотрена возможность использования сведений, полученных при проверке сообщения о преступлении вне рамок процессуальной формы, в качестве доказательств по уголовному делу.

Таким образом, следует отметить современную тенденцию в законодательстве, направленную на унификацию в досудебных стадиях уголовного судопроизводства формы и содержания доказательств, что входит в определенное противоречие с действующей уголовнопроцессуальной доктриной теории доказательств, поскольку процессуальная форма получения сведений на этапе проверки сообщения о преступлении не регламентируется детально Уголовно-процессуальным кодексом РФ, то есть не предусмотрена законом, и ввиду этого полученные сведения не могут быть рассмотрены в качестве доказательств по уголовному дела и использоваться при доказывании в суде.

В свою очередь, отражая собственный взгляд на данную проблему, отметим, что современные подходы к 
определению видов и содержания доказательств на досудебных стадиях уголовного судопроизводства нуждаются в глубоком научном переосмыслении с точки зрения их эффективности в нелегком деле борьбы с таким социально-негативным явлением, как преступность. В связи с этим тенденция на определенное облегчение жизни сотрудников правоохранительных органов, связанная с уменьшением документооборота, используемого в том числе в сфере уголовного судопроизводства, не может не вызывать радости и поддержки. Ведь, как правило, данные, полученные в ходе доследственной проверки, при условии отсутствия у них доказательственного значения как такового ввиду их несоответствия установленной уголовно-процессуальной форме после возбуждения уголовного дела дополнительно получаются уже в форме, предусмотренной УПК РФ, при этом информативное содержание как сведений, полученных на этапе проверки сообщения о преступлении, так и полученных в ходе следственного действия, произведенного после возбуждения уголовного дела, фактически тождественно. Наиболее яркую характеристику данного явления можно привести на примере получения объяснений от очевидца на этапе проверки сообщения о преступлении и последующего его допроса в качестве свидетеля об одних и тех же фактических обстоятельствах с сообщением им одной и той же информации, что приводит к бессмысленной трате времени как следователя, так и самого вызванного на допрос гражданина, который в связи с этим вынужден отвлекаться от своих основных занятий.

В лучшем случае такое доказательство, как показания свидетеля, ранее уже опрошенного о тех же обстоятельствах в рамках проверки сообщения о преступлении, будут иметь хоть какой-то признак информативности. Зачастую при производстве предварительного расследования по уголовным делам, особенно резонансных преступлений, информативное содержание некоторых сведений, сообщенных свидетелями в ходе допроса, остается под серьезным вопросом. Так, например, если по уголовному делу о резонансном убийстве в средствах массовой информации сообщают, что было допрошено 700 свидетелей, однако раскрыть данное преступление еще не удалось, это может означать лишь то, что в уголовном деле содержится 700 бланков протокола допроса свидетелей, содержанием которых является отражение факта о том, что им ничего не известно о местонахождении лица, совершившего данное преступление, или о его личности. По своему содержанию подобные показания вовсе нельзя считать доказательствами, поскольку они не соответствуют такому информативному свойству доказательств, как относимость [7].

Продолжая разговор о значении доказательств на этапе предварительного расследования, не следует обходить вниманием вопрос о необходимости их использования при получении оснований для производства следственных действий. В частности, подобный вопрос относится к наличию фактических и юридических оснований для производства обыска или выемки по уголовному делу.

Так, в положениях УПК РФ, регламентирующих процессуальный порядок производства обыска (ст. 182), указано, что при наличии достаточных данных, указывающих, что в каком-либо месте или у какого-либо лица могут находится предметы или документы, имеющие значение для уголовного дела, может быть произведен их обыск.

В научной литературе уже долгое время находит отражение дискуссия о том, что следует понимать под формулировкой законодателя «достаточные данные» применительно к основаниям для производства обыска в жилище или ином помещении. Так, одна из позиций заключается в том, что в качестве оснований для производства обыска можно допускать любые данные, независимо от их уголовно-процессуальной формы [8]. Так, например, в обоснование для производства обыска могут быть положены данные, которые были получены в результате оперативно-розыскных мероприятий негласным путем в результате проведенной оперативной комбинации. Такие сведения могут быть облечены в форму рапорта оперативного сотрудника, представленного следователю в установленном порядке. Далее следователь на основании лишь одного-единственного рапорта оперативного сотрудника выносит постановление о производстве обыска либо ходатайствует об этом перед судом в случае, если необходимо произвести обыск, например, в жилище. Подобный подход разделяется далеко не всеми исследователями. Так, диаметрально противоположный подход к рассмотрению данной проблемы заключается в том, что для того, чтобы для производства обыска имелись фактические основания, в материалах уголовного дела должны содержаться сведения, облеченные в уголовно-процессуальную форму доказательств [9]. Например, данные о том, что по месту жительства подозреваемого могут находиться предметы, которые были похищены, могут быть получены только из показаний свидетеля, наблюдавшего наличие данного предмета по месту жительства подозреваемого при совместном распитии спиртных напитков, либо о наличии вышеуказанных предметов свидетелю было сообщено самим подозреваемым. При этом данные, на основании которых может быть произведен обыск, могут быть получены только в ходе производства соответствующих следственных действий, направленных на их получение. Так, например, местонахождение похищенного мобильного устройства может быть установлено в ходе производства такого следственного действия, как получение информации о соединениях между абонентами и абонентскими устройствами.

Для производства некоторых следственных действий наличие в материалах уголовного дела связанных с ними доказательств и их конкретного содержания и вовсе является обязательным условием. Так, например, для производства очной ставки требуется наличие в уголовном деле показаний ранее допрошенных лиц, в которых имеются существенные противоречия относительно обстоятельств, имеющих значение для уголовного дела. Для производства предъявления для опознания требуется наличие в содержании показаний лица, которому планируется предъявлять то или иное лицо, предмета для опознания сведений об описании предъявляемого лица, его внешних данных и о факте возможности опознания этого лица, в ином случае производство опознания не представляется целесообразным.

Таким образом, значение доказательств в ходе подготовки производства следственных действий на пред- 
варительном расследовании невозможно переоценить. Правоприменительная практика складывается таким образом, что при получении доказательств, содержащих сведения о тех или иных фактах, они автоматически становятся основаниями и условиями для производства тех или иных следственных действий, представляя собой, таким образом, определенную замкнутую цепочку развития следственной деятельности на всех этапах развития досудебного производства.

К слову, сто́ит отметить, что доказательства имеют значение и для применения мер процессуального принуждения при производстве предварительного расследования. Так, ходатайствуя перед судом об избрании меры пресечения в отношении обвиняемого в виде заключения под стражу, следователь обязан предоставить суду доказательства, подтверждающие одно из оснований для избрания указанной меры пресечения. Так, если в тексте постановления следователя о возбуждении перед судом ходатайства об избрании меры пресечения в виде заключения под стражу указано, что лицо может угрожать свидетелям или потерпевшему, то сведения о таких угрозах либо об их предположительном характере должны быть отражены в соответствующих показаниях потерпевшего или свидетеля. В данном контексте иные документы, например, справка обвиняемого о судимости, в которой содержатся сведения о неоднократном совершении обвиняемым аналогичных преступлений, может подтверждать возможность того, что обвиняемый может продолжить заниматься преступной деятельностью, равно как и наличие в паспорте обвиняемого отметки о регистрации и месте жительства в ином населенном пункте может означать, что этот обвиняемый может скрыться. При отсутствии подобных доказательств в материалах ходатайства следователя суд может признать его необоснованным и отказать в избрании искомой меры пресечения, что, конечно же, может негативно отразиться на ходе предварительного следствия и эффективности его производства.

Одним из пограничных рубежей на предварительном расследовании является привлечение лица в качестве обвиняемого, которое заключается в присвоении качественно нового процессуального статуса лицу, в отношении которого ранее имелись только определенные подозрения. Так, основанием для предъявления лицу обвинения в совершении преступления, согласно ст. 171 УПК РФ, является наличие достаточной совокупности обвинительных по своему содержанию доказательств, подтверждающих виновность данного лица в совершении преступления.

Таким образом, современный институт доказательств нуждается в дальнейшем теоретическом осмыслении с учетом постоянно меняющейся государственно-правовой действительности. Но какими бы процессуальными формами ни обладали доказательства в уголовном судопроизводстве, их основным предназначением должно оставаться установление существенных обстоятельств уголовного дела в целях изобличения лица, совершившего преступление, справедливого разрешения дела по существу и защиты личности от необоснованного, незаконного обвинения и нарушения прав и свобод человека и гражданина.

\section{Литература}

1. Головина В.С. Понятие и историческое развитие доказательств в уголовном процессе / В.С. Головина // Еuropean research : сборник статей XVIII Международной научно-практической конференции, Пенза, 7 декабря 2018 года / Ответственный редактор Г.Ю. Гуляев. Пенза : МЦНС «Наука и Просвещение», 2018. С. 219-221.

2. Лазарева В.А. Трансформация понятия «доказательство» в состязательном уголовном процессе / В.А. Лазарева // Вектор науки Тольяттинского государственного университета. Серия: Юридические науки. 2017. № 2(29). С. 39-43.

3. Исаева Р.М. Свобода оценки доказательств в уголовном процессе: Отдельные аспекты / Р.М. Исаева // Правовое государство: теория и практика. 2017. № 4(50). С. 156-160.

4. Рогава И.Г. Заключение специалиста как один из видов доказательств в уголовном процессе / И.Г. Рогава, Д.В. Яловая // Международный журнал гуманитарных и естественных наук. 2018. № 11-3. С. 141-143.

5. Брянская Е.В. Классификационное значение доказательств в уголовном судопроизводстве / Е.В. Брянская // Российское правосудие. 2017. № 7(135). С. 92-101.

6. Ряполова Я.П. Совесть как нравственный критерий деятельности по оценке доказательств в уголовном процессе / Я.П. Ряполова, Д.Е. Снегирева // Известия Юго-Западного государственного университета. Серия: История и право. 2018. Т. 8. № 4(29). С. 151-161.

7. Зотов Д.В. Доказательства и фикции в уголовном процессе / Д.В. Зотов // Библиотека криминалиста. Научный журнал. 2018. № 1(36). C. $45-50$.

8. Чепрасов М.Г. Доказательства в уголовном процессе / М.Г. Чепрасов, М.А. Федоров // Современная наука: актуальные проблемы теории и практики. Серия: Экономика и право. 2017. № 6. С. $84-87$.

9. Муравьев М.В. О пересмотре правовых стандартов доказывания и доказательств в уголовном процессе / М.В. Муравьев // Юридическая наука и практика: Вестник Нижегородской академии МВД России. 2017. № 2(38). С. 141-145. 


\section{SigNIFICANCE OF EVIDENCE IN THE THEORY OF CRIMINAL PROCEDURE PROOF: PROBLEMS AND WAYS TO SOLVE THEM}

\section{T. Garipov ${ }^{3}$}

Keywords: evidentiary law, admissibility of evidence, witness testimony, expert opinion, initiation of a criminal case, preliminary investigation, internal conviction, discretion of the law enforcement officer.

\section{Abstract.}

Purpose of the work: examining the most problematic aspects of the concept of evidence in the theory of criminal procedure proof in the modern domestic criminal proceedings.

Methods of study: modern dialectical methods of studying the state and legal reality. Among these methods, analysis, synthesis, retrospective analysis, and comparative legal method can be highlighted.

Results of study: the conclusion about the important role evidence and proof play in resolving a criminal case on the merits as well as the need to revise approaches in determining the concept and properties of evidence was set forth. The modern institution of evidence needs further theoretical comprehension considering the constantly changing state and legal reality. However, whatever procedural forms evidence may take in criminal proceedings their main purpose should remain the establishment of essential circumstances of the criminal case in order to convict the person who committed the offence, fairly resolve the case on the merits and protect the individual from unjustified and unlawful accusations and violations of human and civil rights and freedoms.

\section{References}

1. Golovina V.S. Poniatie i istoricheskoe razvitie dokazatel'stv v ugolovnom protsesse. European research : sbornik statei XVIII Mezhdunarodnoi nauchno-prakticheskoi konferentsii, Penza, 7 dekabria 2018 goda. Otvetstvennyi redaktor G.Iu. Guliaev. Penza : MTsNS “Nauka i Prosveshchenie”, 2018, pp. 219-221.

2. Lazareva V.A. Transformatsiia poniatiia "dokazatel'stvo" v sostiazatel'nom ugolovnom protsesse. Vektor nauki Tol'iattinskogo gosudarstvennogo universiteta, seriia: Iuridicheskie nauki, 2017, No. 2(29), pp. 39-43.

3. Isaeva R.M. Svoboda otsenki dokazatel'stv v ugolovnom protsesse: Otdel'nye aspekty. Pravovoe gosudarstvo: teoriia i praktika, 2017, No. 4(50), pp. 156-160.

4. Rogava I.G. Zakliuchenie spetsialista kak odin iz vidov dokazatel'stv v ugolovnom protsesse. Mezhdunarodnyi zhurnal gumanitarnykh i estestvennykh nauk, 2018, No. 11-3, pp. 141-143.

5. Brianskaia E.V. Klassifikatsionnoe znachenie dokazatel'stv v ugolovnom sudoproizvodstve. Rossiiskoe pravosudie, 2017, No. 7(135), pp. 92-101.

6. Riapolova Ia.P. Sovest' kak nravstvennyi kriterii deiatel'nosti po otsenke dokazatel'stv v ugolovnom protsesse. Izvestiia Iugo-Zapadnogo gosudarstvennogo universiteta, seriia: Istoriia i pravo, 2018, t. 8, No. 4(29), pp. 151-161.

7. Zotov D.V. Dokazatel'stva i fiktsii v ugolovnom protsesse. Biblioteka kriminalista. Nauchnyi zhurnal, 2018, No. 1(36), pp. 45-50.

8. Cheprasov M.G. Dokazatel'stva v ugolovnom protsesse. Sovremennaia nauka: aktual'nye problemy teorii i praktiki, seriia: Ekonomika i pravo, 2017, No. 6, pp. 84-87.

9. Murav'ev M.V. O peresmotre pravovykh standartov dokazyvaniia i dokazatel'stv v ugolovnom protsesse. Iuridicheskaia nauka i praktika: Vestnik Nizhegorodskoi akademii MVD Rossii, 2017, No. 2(38), pp. 141-145.

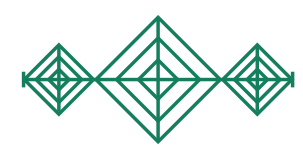

\footnotetext{
3 Timur Garipov, Ph.D. (Law), Senior Lecturer at the Department of Criminal Procedure of Kazan Law Institute of the Ministry of Internal Affairs of Russia, Kazan, Russian Federation. E-mail: ti89ga@mail.ru
} 


\section{ПРЕДЛОЖЕНИЯ ПО СОВЕРШЕНСТВОВАНИЮ СИСТЕМЫ ПРИМЕНЕНИЯ ЦИФРОВЫХ ТЕХНОЛОГИЙ В НОРМОТВОРЧЕСКИХ И ПРАВОПРИМЕНИТЕЛЬНЫХ ПРОЦЕССАХ}

Троян Н. А. ${ }^{1}$

Ключевые слова: цифровая трансформация, система публичной власти, цифровые технологии, информационная безопасность, машиночитаемое право, нормотворческая деятельность и правотворчество, правовая информация, цифровая платформа, информационно-правовой ресурс.

Аннотация.

Цель статьи: формирование подходов для обоснования необходимости создания национальной системы правовой информации, включая входящую в ее состав единую цифровую платформу.

Методы исследования: сравнительно-правовой анализ актуального российского и зарубежного законодательства, стратегических документов и соглашений по вопросам отечественного и зарубежного опыта создания и функционирования систем правовой информации.

Полученные результаты. Сформулированы предложения по совершенствованию законодательства Российской Федерации в сфере правовой информации. Рассмотрены вопросы воздействия цифровых технологий, влияющих не только на право, но непосредственным образом отображающихся на нормотворческие и правоприменительные процессы. Влияние трансформации проявляется в условиях мирового кризиса и реалий пандемии COVID-19, поэтому затронуты актуальные вопросы правового обеспечения стратегических национальных приоритетных направлений развития информационного общества в России и цифровой трансформации. Обоснована необходимость формирования национальной системы правовой информации, включая входящую в ее состав единую цифровую платформу. Исследуя данную тему, автор сделал вывод о том, что в России создан потенциал для внедрения в будущем технологий машиночитаемого права в нормотворческие и правоприменительные процессы.

Определены приоритетные направления использования эффективных решений в отечественной практике и взаимодействия с зарубежными системами правовой информации.

DOI: 10.21681/2226-0692-2021-4-82-92

\section{Введение}

\begin{abstract}
Ceror Чегодня право как система норм, регулирующих оби вектор его развития во многом определяется характером этих отношений $[1$, с. 232]. Поэтому происходящая трансформация в праве образует новые общественные отношения и требует нового регулирования, формирования современных объектов и субъектов информационных правоотношений в процессе цифровизации. Как справедливо указывает А.В. Минбалеев, «цифровой тренд развития общественных отношений и трансформации права на современном этапе формируют систему правового регулирования цифровых технологий» [2, c. 17]. Влияние трансформации проявляется в условиях мирового кризиса и реалий пандемии COVID-19, развиваются различные позиции относительно устоявшихся, классических научных методов в современных условиях. В современный период происходят кардинальные
\end{abstract}

изменения в основаниях науки, которые можно назвать четвертой глобальной научной революцией. Это своего рода вызов, обусловленный цифровизацией и информатизацией $[3$, c. 413, 414]. Цифровизация как глобализация «вносит в нашу жизнь колоссальную неустойчивость, обнажающую хрупкость, зыбкость и неопределенность современного мира [4, с. 254, 255]. Вместе с тем в современных реалиях происходящих изменений и многогранности развития законодательства приобретает особую значимость целенаправленность стратегии правотворчества в соответствии с реализацией долгосрочных задач в различных сферах деятельности. Правильно избранные целевые установки способствуют совершенствованию законодательства в Российской Федерации, а также полномасштабному раскрытию регулятивного потенциала. Ключевое значение для обеспечения эффективного развития правотворчества

\footnotetext{
Троян Наталья Анатольевна, кандидат юридических наук, научный сотрудник сектора информационного права и международной информационной безопасности Института государства и права Российской академии наук, г. Москва, Российская Федерация.

E-mail: n-troyan66@yandex.ru
} 
имеет использование инструментария, разработанного в рамках реализации стратегических национальных приоритетов, нашедших отражение, в частности, в Федеральном законе «О Стратегическом планировании в Российской Федерации» ${ }^{2}$ указе «О Стратегии национальной безопасности Российской Федерации» ${ }^{3}$, а также в Указах Президента РФ от 12 апреля 2021 г. № 213 «Об утверждении Основ государственной политики Российской Федерации в области международной информационной безопасности» ${ }^{4}$ и от 8 ноября 2021г. № 633 «Об утверждении Основ государственной политики в сфере стратегического планирования в Российской Федерации» ${ }^{5}$. Полагаем, что воздействие сквозных технологий влияет не только на право, но непосредственным образом отображается как в правотворчестве в широком смысле этого слова, так и в нормотворческой деятельности, которая, на наш взгляд, является частью правотворческого процесса и, как следствие, определенные трансформации наблюдаются в этих взаимосвязанных процессах. Необходимо отметить не менее важный правовой акт, принятый в соответствии с Указом Президента РФ от 21 июля 2020 г. № 474 «О национальных целях развития Российской Федерации на период до 2030 годы» ${ }^{6}$, где одной из приоритетных национальных целей развития Российской Федерации определена цифровая трансформация. При этом важным показателем для достижения данной цели обозначено достижение «цифровой зрелости» отраслей экономики, социальной сферы, здравоохранения, образования, государственного управления, для правотворческой и нормотворческой деятельности, где должны учитывать обязательность внедрения отечественного программного обеспечения и программно-аппаратных комплексов, созданных на основе технологий искусственного интеллекта. Т.А. Полякова и А.В. Минбалеев полагают, что «ценностные ориентиры связываются с признанием для общества и государства «цифровой зрелости» как новой ценности, к которой нужно стремиться и достигать для повышения благосостояния, качества жизни, улучшения доступности и качества государственных услуг, повышение степени информированности и цифровой грамотности,

\footnotetext{
Федеральный закон от 28.06.2014 № 172-Ф3 (ред. от 31.07.2020) «О стратегическом планировании в Российской Федерации» // Собрание законодательства Российской Федерации. 2014. № 26. Ч. 1. Ст. 3378.

3 Указ Президента РФ от 2 июля 2021 г. № 400 «О Стратегии национальной безопасности Российской Федерации» // Официальный интернет-портал правовой информации. URL: http://pravo.gov.ru (дата обращения: 20.10.2021).

4 Указ Президента РФ от 12 апреля 2021 г. № 213 «Об утверждении Основ государственной политики Российской Федерации в области международной информационной безопасности» // Официальный интернет-портал правовой информации. URL: http://pravo.gov.ru (дата обращения: 06.07.2021).

5 Указ Президента РФ от 8 ноября 2021г. № 633 «Об утверждении Основ государственной политики в сфере стратегического планирования в Российской Федерации» // Официальный интернет-портал правовой информации. URL: http://pravo.gov.ru (дата обращения: 08.11.2021).

6 Указ Президента РФ от 21 июля 2020 г. № 474 «О национальных целях развития Российской Федерации // Официальный интернетпортал правовой информации. URL: http://www.pravo.gov.ru (дата обращения: 06.09. 2021).
}

развития экономического потенциала и информационного общества в Российской Федерации» [5, с. 112]. Безусловно, данное решение вполне может занять свое место в иерархии новых ценностей. Полагаем, что не менее важным является также вопрос о повышении качества и прогнозировании эффективности правотворчества, требующий сегодня научно обоснованных правовых подходов к развитию системы цифровых технологий в нормотворческом и правотворческом процессах, необходимости научного осмысления на основе решений актуальных теоретических и практических проблем. Это нашло отражение в утвержденной Указом Президентом РФ 2 июля 2021 года № 400 Стратегии национальной безопасности $Р \Phi^{7}$, в которой определены направления совершенствования информационного законодательства России. Полагаем, что для решения стратегических приоритетных целей и задач приобретают особую значимость исследования теоретических вопросов качества правотворчества, развитие системы прогнозирования и эффективности нормативных правовых актов, что в значительной степени определяется их скрупулезной подготовкой на всех стадиях проектирования, обсуждения, рассмотрения, экспертизы и принятия всех правотворческих процедур. Именно комплексный подход к механизму правотворчества позволит избежать системных нарушений, а также совершенствование средств и методов обеспечения информационной безопасности на основе применения передовых технологий, включая технологии искусственного интеллекта.

Так, раскрывая понятие правотворческой деятельности в узком смысле, под правотворчеством принято понимать деятельность компетентных органов публичной власти, граждан по разработке и принятию, изменению и отмене нормативных правовых актов. В широком смысле понимание правотворчества включает в себя не только процесс познания, оценки правовых потребностей общества, государства и создание в соответствии с выявленными потребностями новых нормативных правовых актов, изменение и отмену действующих, но и подбор статистики, аналитики и т. д. По сути, поддерживая данный подход (в широком смысле), ряд исследователей отождествляет правотворчество с правообразованием, включающим в себя не только правотворческий, но и предшествующий ему подготовительный процесс формирования права ${ }^{8}$.

\section{Правообразование как комплексный процесс, составной частью которого является правотворчество}

Так, В.С. Нерсесянц отмечает, что «социальный процесс формирования позитивного права - это объективно складывающиеся и субъективно выявляющиеся в жизни общества и государства взаимодействие, влияние разнообразных социальных факторов на фор-

\footnotetext{
Указ Президента РФ от 2 июля 2021 г. № 400 «О Стратегии национальной безопасности Российской Федерации» // Официальный интернет-портал правовой информации. URL: http://pravo.gov.ru (дата обращения: 20.10.2021).

Теория государства и права : учебник / Под ред. Рыбакова О.Ю. М. : Юстиция, 2016. с. 23; 3, с. 47-49.
} 
мирование правовых норм. Этот процесс смыкается с завершающей стадией - юридически оформленным процессом правотворчества государства как организованной деятельностью его правотворческих органов по созданию либо признанию и закреплению в юридически обязательной форме норм позитивного права» ${ }^{9}$. В то же время правообразовательный процесс представляет собой формирование права, в ходе которого общество производит оценку сложившейся социальной правовой действительности, вырабатывает взгляды, анализирует накопленный правовой опыт и, следовательно, создает соответствующие нормы права. Правотворчество - заключительная стадия правообразовательного процесса. Согласимся с предложенным определением профессора С.С. Алексеева, что «Правотворчество (законотворчество) - это специальная деятельность компетентных органов, завершающая процесс правообразования, в результате которой приобретает юридическую силу и вступает в действие закон» ${ }^{10}$. Анализируя данные определения, выявлены различия в толковании содержания этих определений. Так, законотворчество - это деятельность по принятию правовых актов в виде законов, в то время как нормотворчество - это деятельность по изданию нормативных правовых актов. Вместе с тем более широкое содержание имеет правотворчество. Наряду с этим очевидно, что эти понятия не идентичны и не тождественны по отношению и к результату правотворчества. Полагаем, при таком толковании «правотворчество» значительно шире, чем «законотворчество» и «нормотворчество»; в то же время, надо полагать, «нормотворчество» более широкое понятие, чем «законотворчество» ${ }^{11}$.

Важно отметить, что сегодня в России уделяется более пристальное внимание нормотворческому и правотворческому процессу. Этим в значительной степени определяется значимость и развитие конституционноправовых основ, требований обеспечения информационной безопасности п. «м» ст. 71 Конституции РФ, а также необходимость модернизации системы законодательства в соответствии со ст. 15 Конституции РФ $\Phi^{12}$. В связи с этим профессор Е.В. Виноградова отмечает, что «трансформационный потенциал поправок 2020 г. в российскую Конституцию создает импульс для теоретических исследований в направлении обеспечения прав и свобод человека как высшей ценности, определяющей смысл, содержание и применение законов, деятельность всех уровней публичной власти Российской Федерации» [6, с. 28], что обусловливает необходимость определения приоритетов и выработки новых подходов, направленных на совершенствование нормотворческого процесса.

\footnotetext{
9 Проблемы общей теории права и государства / Под общей редакцией академика РАН, д.ю.н, проф. Нерсесянца В.Н. М. : Норма - Инфра, 2001. 832 с.

10 Алексеев С. С. Государство и право. М. : Юрид. лит., 1994. 186 с.

11 Томин В.А. Правотворческая деятельность субъектов Российской Федерации: учебное пособие. СПб. : Изд-во Санкт-Петербургского юридического института (филиала) Академии Генеральной прокуратуры Российской Федерации, 2017. С. 5.

12 Конституция Российской Федерации с изменениями, одобренными в ходе общероссийского голосования 1 июля 2020 г. // Официальный интернет-портал правовой информации. URL: http://www.pravo.gov.ru (дата обращения: 04.07.2020).
}

Совершенно очевидно, что эффективность правотворчества зависит от системного подхода к созданию права, формированию единого механизма правотворчества, включающих согласованное действие разных элементов, начиная с этапа выявления потребности в правовом регулировании и до заключительного этапа реализации принятого правотворческого акта. Представляется, что применение комплексного подхода позволит избежать системных нарушений в правореализации, добиться эффективных результатов.

\section{Актуальная проблема - отсутствие Федерального закона «О нормативных правовых актах»}

Одной из ключевых проблем является отсутствие на федеральном уровне закона «О нормативных правовых актах», что в нынешних реалиях негативно сказывается на нормотворческой и правоприменительной сферах. Как показывает исследование, на сегодняшний день в большинстве субъектов Российской Федерации приняты и действуют законы о нормативных правовых актах, в то время как соответствующий базовый федеральный закон и универсальное определение понятия «нормативный правовой акт» в федеральном законодательстве до сих пор отсутствуют. Согласимся, что децентрализация нормотворческих полномочий между Российской Федерацией и её субъектами в пользу последних, с одной стороны, позволяет субъектам самостоятельно регулировать те или иные виды общественных отношений, исходя из потребностей регионов, с другой - существующее «ситуативное и порой стихийное правотворчество должно уступить место концептуально-осмысленной, прогнозно-аналитической, планируемой скоординированной деятельности органов государственной власти центра и регионов» $[7$, c. 96]. Очевидно, что урегулирование ключевого вопроса правотворческой деятельности о нормативных правовых актах на федеральном уровне является чрезвычайно важным, так как его отсутствие снижает не только качество правового регулирования общественных отношений, но и негативно влияет на правоприменение, создает правовые коллизии. Поэтому на практике при определении нормативности руководствуются выработанными в юридической доктрине признаками нормативного правового акта (неоднократность применения, направленность на неопределенный круг субъектов и т. д.) [8, с. 53-54]. Аналогичный подход выражен в Постановлении Пленума Верховного Суда РФ от 25.12.2018 № $50^{13}$, в котором разъяснено содержание сущности нормативных правовых актов и их отличие от других видов правовых актов. Следует отметить, что признание правового акта нормативным зависит от результатов анализа его содержания. При этом явно прослеживается, что понятие «нормотворчество» необходимо понимать значительно шире деятельности

\footnotetext{
13 Постановление Пленума Верховного Суда РФ от 25.12.2018 № 50 «О практике рассмотрения судами дел об оспаривании нормативных правовых актов и актов, содержащих разъяснения законодательства и обладающих нормативными свойствами» // Бюллетень Верховного Суда РФ. 2019. № 2.
} 
по разработке законопроектов и их принятию, так как она включает в себя разные способы создания правовых норм.

Так, представляется, что нормотворчество - это деятельность, направленная на создание правовых норм, регулирующих различные общественные отношения; важно не только само содержание норм права, но и выражение их в той или иной форме, а также способ создания юридических норм, используемые основные и дополнительные методы правового регулирования, с помощью которых выделяют элементы системы права ${ }^{14}$. Анализируя понятие «нормотворчество», включающее не только деятельность по разработке законопроектов, но и их принятие, следует учитывать, что в него входят различные способы создания правовых норм, принятие нормативных правовых актов путем всенародного голосования (референдума), государственными, муниципальными органами, должностными лицами, в форме как законов, так и подзаконных актов. Заслуживает широкого распространения в юридической науке позиция, что «нормотворчество - это определенная форма юридической деятельности, направленная на создание, конкретизацию, дополнение или отмену норм права в целях упорядочения, уже существующих либо возникновения новых отношений в социуме» [9, с. 34]. Заключение нормативных соглашений (договоров), при которых необходимо обязательное исполнение правовых предписаний, является основным способом нормотворчества. Широкое внедрение цифровых технологий, безусловно, влияет не только на современное развитие общественных отношений, но и воздействует на правотворческую деятельность. Нельзя обойти вниманием и возрастающее социальное значение современных информационных технологий в нормотворческой деятельности, поскольку особенности развития информационного общества во многом детерминированы именно развитием цифровых технологий и значимой ролью информации в современном мире. В настоящее время в условиях цифровизации увеличиваются объемы официальной информации, усиливается значение совершенствования системы обеспечения доступа к правовой информации как основы реализации права человека на информацию. В связи с этим правовая информация приобретает характер стратегического ресурса в системе цифровизации управления. Цифровые технологии, находясь в состоянии постоянного развития, расширяют доступ к информации на основе электронного взаимодействия субъектов информационного обмена, создают условия перехода государственного управления на новый уровень и повышения качества жизни населения. Безусловно, сегодня необходимо новое научное осмысление с позиции информационного права дальнейшего совершенствования правового регулирования и развития системы правовой информации, с учетом открытости правотворческого процесса. Полагаем, что внедрение в правотворческий процесс современных цифровых технологий будет способствовать ее качественному упорядочению. Как отметил Председатель Конституционного Суда Российской

\footnotetext{
14 Нормография: теория и технология нормотворчества : учебник для бакалавриата и магистратуры / Под ред. Ю. Г. Арзамасова. М. : Юрайт, 2019. 460 c.
}

Федерации, цифровизация позволит ““упаковать” нормативные акты в программный код с целью обеспечения стройности их системы, определенности и однозначности их содержания. Важность и успешное решение обозначенной задачи позволит придать системе права необходимую стройность и завершенность, минимизировать имеющиеся пробелы в правовом регулировании» ${ }^{15}$. Думается, что решение данного вопроса остается дискуссионным и несвоевременно: ведь необходим не только правовой потенциал, но и технологическая составляющая, развитие и эксплуатация государственных информационных систем, включающих в себя программно-аппаратную среду, методология, поддерживающая взаимоотношения граждан, государственных органов на базе современных информационных технологий с целью доступа к информации.

\section{Место и роль правовой информации как общественно значимой информации под воздействием цифровых технологий}

В современном мире стремительный прогресс цифровых технологий детерминирует развитие общественных отношений, поэтому информация в жизни общества сегодня приобрела значение ключевого и системообразующего фактора, что создает предпосылки для формирования новых форм воспроизводства, накопления, передачи, защиты информации. Информация обретает особый статус. Обладание правовой информацией является необходимым условием реализации и защиты прав человека, определяющим легитимную организацию поведения субъектов информационного общества, основанного на знании права, правовых предписаниях. В условиях цифровой трансформации роль правовой информации и каналов ее передачи непрерывно возрастает, это влияет и на формирование системы органов публичной власти. Правовая информация стала особым видом информации, обладающим специфическими свойствами и ценностью для всех субъектов общества, что должно обеспечиваться ее актуальностью, достоверностью и доступностью, а также реализацией правовых механизмов противодействия распространению недостоверной («фейковой») информации. Кроме того, следует отметить межотраслевой характер вопроса обеспечения доступа к правовой информации, ее достоверности, юридической значимости, что обусловлено не только социально-экономическим значением этой информации, но и экспоненциальным ростом трансформирующего воздействия цифровых технологий $[10$, c. 25$]$. Учитывая изменения в эпоху цифровой трансформации, появилась необходимость переосмысления и модернизация права на информацию в условиях цифровых технологий и платформенных решений, искусственного интеллекта, облачных технологий, которые позволят получать ценную, полную и достоверную

\footnotetext{
5 Зорькин В.Д. Право в цифровом мире. Размышление на полях Петербургского международного юридического форума // Российская газета. 2018. Столичный выпуск № 115(7578). URL: http://rg.ru/2018/05/29/zorkin-zadacha-gosudarstva-priznavat-izashchishchat-cifrovye-prava-grazhdan.html (дата обращения: 25.11.2021).
} 
правовую информацию [11]. В правовой сфере отмечается ряд тенденций, связанных с развитием цифровых технологий и оказывающих влияние на модели социального регулирования и трансформацию системы права: появление новых дефиниций как основы возникающих и развивающихся правовых институтов, связанных с цифровизацией; возникновение и развитие цифровых прав; широкое применение публичного права для создания новой цифровой экономики; изменение соотношения законов и подзаконных актов; «перенастройка» законодательства на решение задач, связанных с цифровизацией общественных отношений [12]. Вместе с тем связь информации и цифровых технологий не только стремительно расширяется, но и усложняется, и этот процесс находит отражение в развитии системы права. Сегодня необходимо правовое регулирование новых общественных отношений: «цифровой личности», реализации права в цифровой среде, использование больших данных (блокчейн) и т. д. Технологии блокчейн позволяют автоматизировать многие действия, имеющие правовое (юридическое) значение, такие, как совершение и удостоверение сделок, обеспечение конфиденциальности данных и иных. И, как следствие, под влиянием внедрения цифровых технологий принимаются новые нормы права, развиваются новые правовые институты. Сегодня в нашей стране можно с уверенностью говорить об интенсивном курсе научно-технологического развития в рамках стратегических национальных приоритетов в области перспективных высоких технологий (нанотехнологии, робототехники, медицинских, биологических, генной инженерии, информационно-коммуникационных, квантовых, искусственного интеллекта, энергетических, лазерных, аддитивных, создания новых материалов, когнитивных, природоподобных, суперкомпьютерных систем и др. $\left.{ }^{16}\right)$. Вместе с тем цифровые технологии, упрощая и изменяя ряд значимых процедур, не меняют при этом самого характера права как регулятора общественных отношений. Поэтому при формировании государственной политики необходимо законодательно закрепленное понятие «правовая информация», а его отсутствие затрудняет решение стратегической задачи по реализации права на доступ к информации, учитывая значительный массив этой информации, а также отсутствие единых подходов к ее систематизации, определению правового режима и официального характера правовой информации. Заслуживает внимания позиция относительно формирования в Российской Федерации национальной системы правовой информации на основе единой цифровой платформы, которая в современных условиях позволит обеспечивать конституционные права граждан на доступ к информации, ее полноту, достоверность и актуальность. Представляется, что отсутствие единой цифровой платформы также негативно сказывается на нормотворческой и правоприменительной деятельности как на федеральном, так и региональных уровнях. Другим важным фактором, связанным с развитием системы правовой информации в России,

16 Указ Президента РФ от 2 июля 2021 г. № 400 «О Стратегии национальной безопасности Российской Федерации» // Официальный интернет-портал правовой информации. URL: http://pravo.gov.ru (дата обращения: 20.10.2021). является необходимость единых современных теоретических подходов, обеспечения полной, достоверной информацией о нормативных правовых актах всех субъектов. Ключевым требованием к такой государственной системе правовой информации должно стать ее развитие на основе внедрения сквозных информационных технологий и формировании единой информационной инфраструктуры [13].

\section{Применение искусственного интеллекта в нормотворческих и правоприменительных процессах}

Вместе с тем нельзя отрицать значение системных подходов, направленных на повышение качества и соответствия правовой информации требованиям правового государства и информационного общества, это показала практика так называемой регуляторной гильотины в целях отмены устаревших правовых актов. Сегодня ученые ведут дискуссии по поводу создания «электронных кодексов» по французскому образцу, генерации типовых судебных решений при помощи искусственного интеллекта (ИИ), созданию автоматизированной системы контроля судебной практики. Определенное несовершенство российской правовой системы и судебной системы выражается в устаревшем, непрозрачном и избыточном регулировании, неоднозначном толковании правовых норм. С помощью предлагаемой цифровизации правовой системы возможно выявление «устаревших, неработающих, а также неэффективных и неоднозначных норм» ${ }^{17}$ в массиве правовых актов и актов правоприменения. Результатом может стать как корректировка конкретных норм, так и разработка общих рекомендаций по «качественному нормотворчеству» ${ }^{18}$. В связи с этим необходимо отметить первый в России официальный документ в сфере машиночитаемого права, систематизирующий представления о данных технологиях и определяющий основные направления и пути развития: в Концепции развития технологий машиночитаемого права, разработанной Минэкономразвития России и утвержденной руководителем Правительственной комиссии по цифровому развитию, заместителем Председателя Правительства РФ Д. Чернышенко представлены систематизация представлений о методах и сферах перспективного развития технологий машиночитаемого права и предложения по стимулированию развития технологий машиночитаемого права ${ }^{19}$. Надо полагать, что утверждение Концепции является важнейшим шагом для внедрения машиночитаемого права в законотворческий процесс, а также содержит обоснование об эффективности развития машиночитаемого права. Вместе с тем этот документ в современных дискуссиях

\footnotetext{
17 Судебный процессор. Газета «Коммерсанть», № 210 (6204) от 13.11.2017. URL: https://www.kommersant.ru/doc/3466185 (дата обращения: 24.09.2021).

18 Судебный процессор. Газета «Коммерсанть», № 210 (6204) от 13.11.2017. URL: https://www.kommersant.ru/doc/3466185 (дата обращения: 24.09.2021).

19 Министерство экономического развития Российской Федерации. URL: https://www.economy.gov.ru/material/news/v_pravitelstve_ utverdili_koncepciyu_razvitiya_tehnologiy_mashinochitaemogo_ prava.html (дата обращения: 10.10.2021).
} 
вызвал множество противоречивых позиций. В любом случае необходимо правовое решение данного вопроса, теоретическое осмысление понимания этой технологии. Можно предполагать эффективное использование этой Концепции в дальнейшем, ее востребованность в законотворчестве, судопроизводстве, при заключении сделок, стандартизации и сертификации, непротиворечивое изложение правовых норм с целью повышения удобства правоприменения для государства, предпринимательского сообщества и граждан. Предполагается, что посредством инструментов машиночитаемого права возможно обеспечить «встраивание» норм права в работу информационных систем, предоставляющих различные сервисы в автоматическом режиме, а также обменивающихся данными без участия человека. При этом в Российской Федерации в настоящее время существует потенциал для внедрения технологий машиночитаемого права в реальные нормотворческие и правоприменительные процессы. Рассуждая о сложностях применения и внедрения современных технологий машиночитаемого права во все сферы законодательства России, можно прийти к выводу, что сдерживает процесс прежде всего новизна данного направления, отсутствие единых подходов к таким технологиям, которые требуют дополнительной проработки и адаптации. Совершенно очевидной проблемой является недостаток квалифицированных специалистов в данной области.

Вместе с тем сегодня «цифровая реальность» создает новый вызов для правовой системы и законотворчества России. Поэтому в условиях цифрового развития российского законотворчества необходима реализация внедрения в законотворческий процесс цифровых технологий, способных оптимизировать систему действующего законодательства. Кроме того, необходимо внедрять в законотворческую деятельность правовое прогнозирование на основе современных технологий [14], привлекать к участию в процессе законотворчества негосударственные структуры, включая сетевые сообщества, начиная со стадии законодательной инициативы и заканчивая процессом обсуждения принимаемых законодательных актов и результатов применения действующего законодательства.

\section{Приоритетные направления развития} национальной системы правовой информации

Сегодня развитие информационных систем в условиях цифровизации на базе современных информационно-коммуникационных технологий (ИКТ) является политически важной государственной задачей стратегического характера. В информационной сфере России регулирование требует комплексного подхода к формированию национального законодательства, регламентирующего создание и функционирование информационных систем различного вида. Актуальной является задача выявления объективных закономерностей правового и технического регулирования создания и использования цифровых технологий. Однако ее решение требует новых подходов и современных механизмов регулирования в условиях цифровых технологий, что справедливо отмечают исследователи [14]. Сегодня, переходя в качественно новую эпоху, нельзя не отметить внедрение цифровых электронных сервисов, электронных государственных услуг, включая консультирование и информирование онлайн, открытость информации о деятельности органов публичной власти на основе прорывных технологий, включая технологии искусственного интеллекта. Между тем, несмотря на принимаемые меры, уровень используемых в государственном управлении цифровых и иных инновационных технологий пока нельзя признать достаточным.

В соответствии с постановлением Правительства РФ № 953 «Об обеспечении доступа к информации о деятельности Правительства Российской Федерации и федеральных органов исполнительной власти» ${ }^{20}$ осуществляется опубликование правовых актов на официальных сайтах органов государственной власти, что является электронным источником правовой информации. Заслуживает внимания также использование опыта работы с правовой информацией органов законодательной власти. При этом система правовой информации Федерального Собрания РФ по уровню информатизации процессов и процедур, оснащенности информационными ресурсами и базами данных, обеспеченности автоматизированными системами взаимодействия с субъектами Федерации, странами СНГ и другими зарубежными государствами - одна из наиболее наукоемких и компьютеризированных. Кроме того, граждане имеют возможность знакомиться с законопроектами и прилагаемыми к ним документами еще до их принятия, поскольку они размещаются в открытом доступе на официальном интернет-портале Государственной Думы Федерального Собрания РФ. Сегодня также широко пользуются правовой информацией, имеющейся в правовой базе Государственной Думы России на сайте в сети Интернет, которая включает данные автоматизированной системы обеспечения законодательной деятельности (АСОЗД) и автоматизированной информационно-поисковой системы (АИПС) «Нормативно-правовые акты Федерального Собрания Российской Федерации». Федеральные органы исполнительной власти должны раскрывать информацию о проектах правовых актов, разрабатываемых ими, а также проводить соответствующее общественное обсуждение на специализированном государственном портале. В последнее время практически все значимые законопроекты проходят процедуру общественного обсуждения. Важно применение информационно-правового мониторинга, электронного документооборота, внедрение цифровых технологических систем. Единая информационно-телекоммуникационная сеть (Интранет) Госдумы функционально объединена с сетями Совета Федерации, Администрации Президента РФ, Центральной избирательной комиссии России и некоторых других органов системы публичной власти. Вместе с тем правовая информация в базах информационных систем не имеет официального характера. Проекты правовых актов федеральных органов исполнительной власти доступны также на информаци-

\footnotetext{
Постановление Правительства РФ № 953 «Об обеспечении доступа к информации о деятельности Правительства Российской Федерации и федеральных органов исполнительной власти» // Официальный интернет-портал правовой информации. URL: http://pravo.gov.ru (дата обращения: 10.10.2021)
} 
онном ресурсе проектов нормативных правовых актов http://regulation.gov.ru ${ }^{21}$, что позволяет участвовать в их общественном обсуждении. Необходимо упомянуть Официальный интернет-портал правовой информации www.pravo.gov.ru ${ }^{22}$ - сетевое издание, которое обеспечивает официальное опубликование правовых актов, а также входит в государственную систему правовой информации как источник официального опубликования актов. Между тем нельзя признать полным весь массив правовой информации, содержащийся на этом портале как источнике официального опубликования актов, так как он создан в 2011 г. Сегодня наиболее востребованными остаются электронные источники распространения правовой информации «КонсультантПлюс», «Гарант», «Кодекс» и др., однако содержащаяся в них правовая информация не является официальной. Полагаем, что в условиях информационного общества и цифровой трансформации в России отсутствие унифицированного законодательного закрепления понятия «правовая информация» влияет на формирование государственной политики, направленной на реализацию права на доступ к информации, учитывая значительный массив этой информации, отсутствие единых подходов к ее систематизации, определению правового режима, а также официального статуса. Особенно это очевидно в нормотворческой и правоприменительной практике, а также в деятельности судебной системы. В связи с этим полагаем, что сегодня формирование в Российской Федерации национальной системы правовой информации необходимо для обеспечения основных конституционных прав граждан по доступу к правовой информации, ее полноты, достоверности и актуальности. В настоящее время необходим переход от модели предоставления и получения достоверной информации к модели многоуровневого и многостороннего информационного взаимодействия, необходимого для системного решения вопросов обеспечения национальных интересов в цифровой среде.

Полагаем, что национальная система правовой информации в условиях цифровизации в России должна развиваться и формироваться на базе цифровых технологий как упорядоченная совокупность электронных информационно-правовых ресурсов, информационных процессов на основе единой программно-аппаратной среды, обеспечивающей сбор, обработку, хранение, передачу и предоставление правовой информации в электронной форме. Таким образом, требование относительно правовой информации связано с необходимостью формирования в России на новом современном уровне государственной системы правовой информации, конкурентноспособной и основанной на применении прорывных технологий. Развитие конвергентных технологий, технологии больших данных открывает но-

21 Федеральный портал проектов нормативных правовых актов. Официальный сайт для размещения информации о подготовке федеральными органами исполнительной власти проектов нормативных правовых актов и результатах их общественного обсуждения. URL: http://regulation.gov.ru (дата обращения: 10.10.2021).

22 Официальный интернет-портал правовой информации. URL: http://pravo.gov.ru (дата обращения: 10.10.2021). вые возможности для работы с огромными массивами правовой информации.

\section{Зарубежный опыт создания и правового регулирования систем правовой информации}

В этом плане, безусловно, заслуживает внимания опыт создания национальной системы в Республике Беларусь, где были унифицированы процессы создания и распространения нормативной правовой информации на основе создания Национального центра правовой информации. Исследование показывает, что в Республике Беларусь система правовой информации прошла прогрессивный путь организационных, правовых и технологических преобразований и сформировала единую высокотехнологическую систему учета всех правовых актов государства, позволившую провести инвентаризацию всего белорусского законодательства. На основе внедрения инновационных решений создан электронный свод правовых актов, обеспечена их систематизация и приведение в контрольное состояние. Введены в эксплуатацию Национальный правовой Интернет-портал Республики Беларусь, разработаны информационно-правовые ресурсы и технологии централизованного сбора, хранения, обработки, актуализации правовой информации и ее официального опубликования, сформирована система распространения и предоставления официальной правовой информации. Введенный в эксплуатацию сайт «Правовой форум Беларуси» имеет статус официального информационного ресурса - посредника между гражданами и государственными органами при проведении публичных обсуждений проектов нормативных правовых актов. Обращает внимание, что его правовой статус закреплен Законом Республики Беларусь «О нормативных правовых актах» в качестве основной платформы в сети Интернет для организации публичных обсуждений. Важным направлением развития нормотворческой деятельности в республике определена автоматизация подготовки и принятия правовых актов. Разработка данной автоматизированной информационной системы позволит объединить все нормотворческие органы и стадии нормотворческого процесса, включая подготовку текста проекта, его согласование, публичное обсуждение, подписание акта и его официальное опубликование. В системе планируется автоматизировать механизмы контроля за языковыми, терминологическими требованиями и требованиями нормотворческой техники, а элементы машинного интеллекта позволят осуществлять подготовку первичного проекта правового акта. Данная система призвана обеспечить полный и транспарентный цикл подготовки актов законодательства. В связи с этим основной тенденцией развития правовой информатизации в Республике Беларусь является системность использования современных цифровых технологий на единой информационно-технологической площадке Государственной системы правовой информации (ГСПИ) как в прикладных процессах работы с законодательством, так и в нормотворческой деятельности ${ }^{23}$. Полагаем, что аналогичным образом на базе Научного центра правовой информации

23 Нацыянальны цэнтр прававой інфармацыі Рэспублікі Беларусь (НЦПI). URL: http://ncpi.gov.by (дата обращения: 20.10.2021). 
при Минюсте России целесообразно создание Национального центра правовой информации в Российской Федерации, учитывая опыт НЦПИ по изучению проблем, связанных с правовой информатизацией и правовой информацией, систематизацией и учетом правовых актов в Российской Федерации. Полагаем, что придание учреждению официального статуса необходимо для развития системы правовой информатизации, а также позволит обеспечить популяризацию имеющихся правовых ресурсов, учитывая их уникальность и большой опыт работы данного учреждения с правовой информацией, начиная практически с 70-х годов прошлого века [14]. Полагаем, что основная задача на данный момент - это решение важнейшей проблемы придания государственной системе правовой информации статуса национальной; развитие информационной инфраструктуры этой системы в настоящее время является одной из стратегических задач Российской Федерации, реализация которой должна быть основана на междисциплинарных научных подходах, анализе зарубежного опыта, интеграции цифровых средств, используемых в правовой сфере, включая технологии больших данных, искусственного интеллекта, облачных технологий и платформенных решений, которые позволят обеспечить своевременность, полноту и достоверность правовой информации. Представляется, что правовое регулирование в информационной сфере является сложной задачей, сложность решения которой пока не вполне осознается юридической наукой - гораздо более сложной и важной задачей, чем автоматизированное генерирование законов и нормативных актов [15].

Учитывая, что Министерство юстиции Российской Федерации является органом, ответственным за реализацию государственной политики в области правового информирования, так как имеет значительный опыт в этой области, направления его деятельности по обеспечению единства национального правового пространства взаимосвязаны с большинством функций и полномочий. При этом необходимо отметить значимость Министерства юстиции, имеющего двухсотлетнюю историю, которое в Российской империи было главным институтом, занимающимся законопроектной и правоохранительной деятельностью, имеющего исторически сложившийся опыт работы в области систематизации законодательства, аккумулирования значительных массивов правовой информации и выполнения ряда полномочий по правовому просвещению, правовому мониторингу и учету нормативных правовых актов федеральных органов исполнительной власти, субъектов Российской Федерации, муниципальных органов, а также иных электронных информационно-правовых ресурсов, относящихся к компетенции Минюста России. В связи с этим полагаем, что целесообразно определить Министерство юстиции Российской Федерации в качестве уполномоченного органа по ведению национальной системы правовой информации и возложить на него полномочия по реализации государственной информационной политики в области правовой цифровизации и координации этой деятельности в Российской Федерации.

Совсем недавно Постановлением Правительства РФ от 18 октября 2021 г № 1765 «О внесении изменений в государственную программу Российской Федерации
«Юстиция» ${ }^{24}$ были утверждены внесенные в государственную программу изменения, где основным направлением деятельности, реализуемым Минюстом России в рамках государственной программы в области цифровой трансформации, является участие совместно с заинтересованными федеральными государственными органами в создании единого государственного информационного ресурса оцифрованных нормативных правовых актов, содержащего все нормативные правовые акты федерального, регионального и муниципального уровней в актуальном, структурированном, взаимосвязанном виде. Реализация данного направления в сфере юстиции будет способствовать достижению целей обеспечения государственной и общественной безопасности в части защиты основных прав и свобод человека и гражданина.

Безусловно, сегодня представляется необходимым перевод в цифровой формат следующего: правотворческие юридические технологии, юридическое прогнозирование, правовое моделирование, экспертизы проектов нормативных правовых актов, оценки регулирующего воздействия и т. д.; это обеспечит переход правотворческой деятельности на новый качественный уровень.

Выявленные в ходе данного исследования проблемы должны стать предметом дальнейшего научного исследования, необходимо развитие доктринальной, программно-технологической, нормативной правовой и организационной основ цифровизации правовой сферы для решения задач государственного управления, нормотворчества и правотворческой деятельности, электронной коммуникации государства и общества, развития национальных систем доступа к правовой информации как неотъемлемого элемента, обеспечивающего эффективное функционирование государства, системы органов публичной власти и правовой системы в информационном обществе, а также формирование на этой основе общего (глобального) информационно-правового пространства в рамках межгосударственных объединений. Важно, чтобы при модернизации системы права и правотворчества сохранялись нравственные начала, поэтому исключить человека как носителя нравственности из процесса правотворчества невозможно [16].

В настоящее время наблюдается активная динамика информационно-правового взаимодействия государств - участников СНГ, ЕврАзЭС и иных региональных союзов в рамках межгосударственных интеграционных процессов, в ходе которых усиливается решение организационно-правовых вопросов обеспечения единого экономического пространства. В связи с этим формируется необходимость перехода реализации государственных функций на новый уровень для противодействия вызовам, угрозам и рискам информационного общества в условиях цифровизации [17].

\section{Заключение}

Резюмируя, отметим, что система органов публичной власти, объединяющая органы законодатель-

24 Постановление Правительства РФ от 18 октября 2021 г. № 1765 «О внесении изменений в государственную программу Российской Федерации «Юстиция» // Официальный интернет-портал правовой информации. URL: http://pravo.gov.ru (дата обращения: 28.10.2021). 
ной, исполнительной, муниципальной власти, иные государственные органы, в своей нормотворческой и правоприменительной деятельности сегодня должна базироваться на цифровых технологиях. В условиях цифровизации в информационном обществе следует признать необходимость нового взгляда на правовые институты в эпоху современных цифровых технологий, последовательной адаптации традиционных правовых механизмов к новым реалиям [18]. При этом решение обозначенных задач имеет комплексный характер, поскольку включает в себя внедрение новых технологий в нормотворческий процесс (проведение правового мо- ниторинга, оценку регулирующего воздействия, общественное обсуждение проектов нормативных правовых актов и т. д.). Таким образом, в целях информационноправового обеспечения совершенствования нормотворческой деятельности необходимы: национальная система правовой информации на основе единой цифровой платформы, разработки нового правового классификатора, обеспечения информационной безопасности, а также научно-правовое обоснование системы формирования потенциала для внедрения технологий машиночитаемого права в реальные нормотворческие и правоприменительные процессы.

\section{Литература}

1. Пашенцев Д.А., Залоило М.В. Влияние современных цифровых технологий на содержание и характер правотворческой деятельности: теоретико-правовой аспект // Вестник Нижегородской академии МВД России. 2018. № 4 (44). С. $231-235$.

2. Минбалеев А.В. Механизмы и модели регулирования цифровых технологий : монография. М. : Проспект, 2020.224 с.

3. Савенков А.Н. Государство и право в период кризиса современной цивилизации. М. : Проспект, 2020. 448 с.

4. Зорькин В.Д. Цивилизация права и развитие России. 2-е изд., исп. и доп. М. : Норма: ИНФРА-М, 2016. 416 с.

5. Полякова Т.А., Минбалеев А.В. Понятие и правовая природа «цифровой зрелости» // Государство и право. 2021. № 9. C. 107-116.

6. Виноградова Е.В. Принятие отечественных конституций и принятие поправок к ним // Правовая политика и правовая жизнь. Академический и вузовский юридический научный журнал. 2020. № 4(81). С. 19-28.

7. Рыбаков О.Ю., Рыбакова О.С. Нормотворческая деятельность субъектов Российской Федерации: проблемы и пути решения // Вестник Кемеровского государственного университета. Серия: Гуманитарные и общественные науки. 2017. № 2. С. 95-99.

8. Вопросы права государственного языка и языка права (традиции, новации, развитие) : коллективная монография / Киянова О.Н., Кичева И.В., Арсанукаева М.С. [и др.]. Москва-Берлин, 2020. 124 с.

9. Полякова Т.А., Бойченко И.С., Троян Н.А. Информационно-правовые механизмы электронного взаимодействия в сфере правовой информации в условиях цифровизации // Мониторинг правоприменения № 1(38). 2021. C. 24-27. DOI: 10.21681/2226-0692-2021-1-24-27.

10. Петровская О.В. Принципы достоверности в информационном праве в условиях цифровой трансформации // Мониторинг правоприменения № 3(40). 2021. С. 46-50. DOI: 10.21681/2226-0692-2021-3-46-50 .

11. Хабриева Т.Я. Право перед вызовами цифровой реальности // Журнал российского права. 2018. № 9. С. 5-16.

12. Карцхия А.А. Искусственный интеллект как средство управления в условиях глобальных рисков // Мониторинг правоприменения. 2020. № 1(34). С. 45-50.

13. Минбалеев А.В. Ограничения в процессе регулирования цифровой экономики / Правовое регулирование цифровой экономики в современных условиях развития высокотехнологичного бизнеса в национальном и глобальном контексте : монография. Под общ. ред. В.Н. Синюкова, М.А. Егоровой. М., 2019. С. 40-51.

14. Троян Н.А. Влияние цифровой экономики как поступательный фактор эффективного развития современного общества // Формирование системы правового регулирования обеспечения информационной безопасности в условиях больших вызовов в глобальном информационном обществе : сб. научных трудов. М., 2019. С. 338.

15. Бочков С.И., Макаренко Г.И., Федичев А.В. Об Окинавской хартии глобального информационного общества и задач развития российских систем коммуникации // Правовая информатика. 2018. № 1. С. 4-14.

16. Полякова Т.А. Химченко А.И. Юридическое прогнозирование как составляющая стратегического планирования для целей развития информационного права // Мониторинг правоприменения. 2019. № 2(31). С. 38-42. DOI: 10.21681/2226-06922019-2-38-42.

17. Полякова Т.А., Камалова Г.Г. Концептуальные основания развития института доступа к информации в Российской Федерации при применении информационных технологий // Мониторинг правоприменения. 2020. № 4(37). C. 22-27. DOI: 10.21681/2226-0692-2020-4-22-27.

18. Карцхия А.А. Цифровая трансформация права // Мониторинг правоприменения. 2019. № 1(30). С. 25 -29.

Статья выполнена по Государственному заданию № 0136-2021-0042 «Правовое регулирование изифровой экономики, искусственного интеллекта, информационной безопасности».

Рецензент: Полякова Татьяна Анатольевна, доктор юридических наук, профессор, главный научный сотрудник Института государства и права РАН, Москва, Россия. E-mail:polyakova_ta@mail.ru 


\title{
Proposals for improving the system of applying digital technologies IN LAW-MAKING AND LAW ENFORCEMENT PROCESSES
}

\section{N. $\operatorname{Troian}^{25}$}

Keywords: digital transformation, public authority system, digital technologies, information security, machinereadable law technologies, law-making activities, legal information, digital platform, legal information resource.

\begin{abstract}
.
Purpose of the paper: developing approaches for justifying a need for setting up a national legal information system including a single digital platform being a part of it.

Methods of study: comparative legal analysis of the current domestic and foreign laws, strategic documents and agreements concerning the domestic and foreign experience of setting up and operating legal information systems.

Using the said methods made it possible. In the course of the study, a comparative legal analysis directly used in studying domestic and foreign experience of setting up and operating legal information systems with a view to identify the general tendencies and national peculiarities was carried out.

Results obtained. Proposals for improving the laws of the Russian Federation in the field of legal information are presented. Questions of impact of digital technologies which not only exert their influence on law but also have direct reflections in law-making and law enforcement processes are considered. The impact of transformation manifests itself under the conditions of the world crisis and COVID-19 pandemic realia, so topical questions of legal support for strategic national priorities in the development of information society in Russia and digital transformation are touched upon. A justification is given for a need for setting up a national legal information system including a single digital platform being a part of it. Studying this topic, the author came to the conclusion that a potential for future application of machine-readable law technologies in real law-making and law enforcement processes has been created in Russia.

Priority lines of using efficient solutions in domestic practice and interacting with foreign legal information systems are identified.
\end{abstract}

\section{References}

1. Pashentsev D.A., Zaloilo M.V. Vliianie sovremennykh tsifrovykh tekhnologii na soderzhanie i kharakter pravotvorcheskoi deiatel'nosti: teoretiko-pravovoi aspekt. Vestnik Nizhegorodskoi akademii MVD Rossii, 2018, No. 4 (44), pp. 231-235.

2. Minbaleev A.V. Mekhanizmy i modeli regulirovaniia tsifrovykh tekhnologii : monografiia. M. : Prospekt, 2020. 224 pp.

3. Savenkov A.N. Gosudarstvo i pravo v period krizisa sovremennoi tsivilizatsii. M. : Prospekt, 2020. 448 pp.

4. Zor'kin V.D. Tsivilizatsiia prava i razvitie Rossii. 2-e izd., isp. i dop. M. : Norma: INFRA-M, 2016. 416 pp.

5. Poliakova T.A., Minbaleev A.V. Poniatie i pravovaia priroda "tsifrovoi zrelosti". Gosudarstvo i pravo, 2021, No. 9, pp. $107-116$.

6. Vinogradova E.V. Priniatie otechestvennykh konstitutsii i priniatie popravok k nim. Pravovaia politika i pravovaia zhizn'. Akademicheskii i vuzovskii iuridicheskii nauchnyi zhurnal, 2020, No. 4(81), pp. 19-28.

7. Rybakov O.Iu., Rybakova O.S. Normotvorcheskaia deiatel'nost' sub"ektov Rossiiskoi Federatsii: problemy i puti resheniia. Vestnik Kemerovskogo gosudarstvennogo universiteta, seriia: Gumanitarnye i obshchestvennye nauki, 2017, No. 2, pp. 95-99.

8. Voprosy prava gosudarstvennogo iazyka i iazyka prava (traditsii, novatsii, razvitie): kollektivnaia monografiia. Kiianova O.N., Kicheva I.V., Arsanukaeva M.S. i dr. Moskva-Berlin, 2020. 124 pp.

9. Poliakova T.A., Boichenko I.S., Troian N.A. Informatsionno-pravovye mekhanizmy elektronnogo vzaimodeistviia v sfere pravovoi informatsii v usloviiakh tsifrovizatsii. Monitoring pravoprimeneniia No. 1(38), 2021, pp. 24-27. DOI: 10.21681/2226-0692-2021-124-27.

10. Petrovskaia O.V. Printsipy dostovernosti v informatsionnom prave v usloviiakh tsifrovoi transformatsii. Monitoring pravoprimeneniia No. 3(40), 2021, pp. 46-50. DOI: 10.21681/2226-0692-2021-3-46-50 .

11. Khabrieva T.Ia. Pravo pered vyzovami tsifrovoi real'nosti. Zhurnal rossiiskogo prava, 2018, No. 9, pp. 5-16.

12. Kartskhiia A.A. Iskusstvennyi intellekt kak sredstvo upravleniia v usloviiakh global'nykh riskov. Monitoring pravoprimeneniia, 2020 , No. 1(34), pp. 45-50.

13. Minbaleev A.V. Ogranicheniia v protsesse regulirovaniia tsifrovoi ekonomiki. Pravovoe regulirovanie tsifrovoi ekonomiki v sovremennykh usloviiakh razvitiia vysokotekhnologichnogo biznesa v natsional'nom i global'nom kontekste : monografiia. Pod obshch. red. V.N. Siniukova, M.A. Egorovoi. M., 2019, pp. 40-51.

25 Natalia Troian, Ph.D. (Law), Researcher at the Sector of Information Technology Law and International Information Security of the Institute of State and Law of the Russian Academy of Sciences, Moscow, Russian Federation. E-mail: n-troyan66@yandex.ru 
14. Troian N.A. Vliianie tsifrovoi ekonomiki kak postupatel'nyi faktor effektivnogo razvitiia sovremennogo obshchestva. Formirovanie sistemy pravovogo regulirovaniia obespecheniia informatsionnoi bezopasnosti $\mathrm{v}$ usloviiakh bol'shikh vyzovov $\mathrm{v}$ global'nom informatsionnom obshchestve : sb. nauchnykh trudov. M., 2019, p. 338.

15. Bochkov S.I., Makarenko G.I., Fedichev A.V. Ob Okinavskoi khartii global'nogo informatsionnogo obshchestva i zadach razvitiia rossiiskikh sistem kommunikatsii. Pravovaia informatika, 2018, No. 1, pp. 4-14.

16. Poliakova T.A. Khimchenko A.I. Iuridicheskoe prognozirovanie kak sostavliaiushchaia strategicheskogo planirovaniia dlia tselei razvitiia informatsionnogo prava. Monitoring pravoprimeneniia, 2019, No. 2(31), pp. 38-42. DOI: 10.21681/2226-0692-2019-2-38-42 .

17. Poliakova T.A., Kamalova G.G. Kontseptual'nye osnovaniia razvitiia instituta dostupa k informatsii v Rossiiskoi Federatsii pri primenenii informatsionnykh tekhnologii. Monitoring pravoprimeneniia, 2020, No. 4(37), pp. 22-27. DOI: 10.21681/2226-06922020-4-22-27 .

18. Kartskhiia A.A. Tsifrovaia transformatsiia prava. Monitoring pravoprimeneniia, 2019, No. 1(30), pp. 25-29. 


\title{
РеценЗИЯ НА МОНОГРАФИЮ С.И. ЗАХАРЦевА «ПРАВО: НОВЫЕ ИДЕИ И ПРОЧТЕНИЯ》
}

\author{
Сальников В. П. ${ }^{1}$, Хабибулин А. Г.. ${ }^{2}$ Числов А. И. ${ }^{3}$
}

\begin{abstract}
Мы (авторы) относимся к числу ученых, посвятивших свою жизнь изучению теории и философии права. Разумеется, нам известны работы «коллег по цеху», мы следим за их новыми публикациями и идеями.

Вместе с тем новых работ не так много. Поэтому нас искренне порадовал выход в свет в 2021 году очередной монографии С.И. Захарцева под названием «Право: новые идеи и прочтения» [5], тем более, что уважаемый автор является нашим давним другом и соавтором, а многие отраженные в книге идеи мы начинали разрабатывать совместно.
\end{abstract}

Данной книге посвящена настоящая рецензия.

DOI: 10.21681/2226-0692-2021-4-93-98

2014 году один из авторов настоящей рецензии совместно с С.И. Захарцевым обосновал компрехендную теорию права. Ее смысл связывается со строго объективным, реальным, деидеализированным, деидеологизированным познанием права, не допуская господства какой-либо концепции. Чем объективней будет оцениваться право как сложное, противоречивое, многогранное социальное явление, четче будут вскрываться все его противоречия и изъяны, сильные и слабые стороны, возможности и пределы этих возможностей и т. д., - тем скорее получится прийти к познанию права [5, c. 30-31]. Стало расхожим наше сравнение права с бриллиантом. Как известно, наиболее распространенная огранка бриллианта составляет 57 граней. И думается, что ученые видят ту или иную грань камня, подчас даже подробно рассматривают ее, при этом упуская из виду, что есть еще как минимум 56 граней этого же камня. То же происходит и с правом. Специалисты по одной грани права судят о нем как о целом. Очевидно, что получаемые таким образом теории со временем упираются в неразрешимые противоречия. Далее появляются новые мыслители, которые также, иногда искренне полагая, что видят предмет целиком, заостряют взгляды на одном из проявлений предмета. Их теории также опровергаются другими концепциями, которые тоже далеки от совершенства. Исторически сколько было различных концепций понимания права? Казалось бы, немало (позитивистская, естественная, договорная, психологиче- ская, историческая, социологическая и т. д.). Однако их и не так много, как граней бриллианта. Мы считаем, что пока не будет создано значительное количество самостоятельных концепций, объективно и полно раскрывающих конкретные грани права, единого и общего понятия нам создать не удастся. Но как только количество определений права достигнет критической массы, оно перерастет в качество, в результате чего мы получим понимание права на уже совершенно новом уровне, может быть, удивительном для нас всех [10, с. 11-26; 11, c. $4-13 ; 12$, c. 93-103].

Рецензируемая книга С.И. Захарцева во многом посвящена дальнейшей разработке компрехендной теории права. Им были уточнены вопросы как положительных, так и негативных граней права. Например, показаны такие его негативные проявления, как развратность и аморальность (однополые браки и продажа наркотиков в разных государствах), фактический приоритет показаний в расследовании и особенно признания подсудимым вины (это по-прежнему имеется практически во всех странах), формализм и т. д. Многие ученые попрежнему избегают смотреть на право объективно, не хотят видеть его негативных проявлений. Но ведь такие проявления (названные нами грани) у права есть.

Следует положительно отметить широкое использование С.И. Захарцевым трудов выдающихся философов как России, так и зарубежья. Особенно много внимания, в том числе в контексте диалектики, уделе-

\footnotetext{
1 Сальников Виктор Петрович, доктор юридических наук, профессор, академик РАЕН, главный редактор журнала «Юридическая наука: история и современность», советник ректората Русской христианской гуманитарной академии, Заслуженный деятель науки Российской Федерации, Почетный работник высшего профессионального образования Российской Федерации, г. Санкт-Петербург, Российская Федерация. E-mail: fonduniver@bk.ru

2 Хабибулин Алик Галимзянович, доктор юридических наук, профессор, заведующий кафедрой экономических и финансовых расследований Высшей школы государственного аудита (факультета) Московского государственного университета им. М.В. Ломоносова, профессор кафедры теории государства и права и политологии юридического факультета МГУ им. М.В. Ломоносова, Заслуженный юрист Республики Башкортостан, г. Москва, Российская Федерация. E-mail: 21alik@mail.ru

3 Числов Александр Иванович, доктор юридических наук, профессор, профессор кафедры кадрового и морально-психологического обеспечения деятельности ОВД Тюменского института повышения квалификации сотрудников МВД России, г. Тюмень, Российская Федерация. E-mail:944343@gmail.com
} 
но Гегелю. Трудам Гегеля С.И. Захарцев и мы посвятили три предыдущие монографии [9; 16; 20]. При этом С.И. Захарцев внимательно перечитал гегелевскую «Философию права» и заставил нас по-новому посмотреть на понимание немецким философом государства и общества для права, а также на отдельные философские оценки права. Добавим, что Гегель любил сравнивать познание права с художником. Дескать, у каждого человека есть пальцы, он может получить кисть и краски, но это еще не сделает его художником. И мысль о праве не есть нечто такое, чем обладает каждый [3, с. 58]. Продолжая это красивое суждение, С.И. Захарцев написал, что чаще сравнивает право с врачами. Он пишет: «Дело в том, что от дурной картины или плохого исполнения музыки лишь испортится настроение. А от ошибки врача, неправильного понимания процесса болезни и лечения, ложного диагноза, невнимательности и даже банальной грязи в больнице может зависеть жизнь! То же касается и права, его невнимательного прочтения, неправильного понимания, ложного толкования, заведомо ложного и «грязного» использования» [5, с. 124]. В книге немало и других интересных авторских афоризмов С.И. Захарцева, высоко оцененных юридическим сообществом. Например, такой: «Если Вы видите в праве только хорошее и не замечаете банальных противоречий, а подчас и откровенных глупостей - Вы не юрист!».

Кроме того, С.И. Захарцев по-новому взглянул на работы по философии права Л.Н. Толстого, Ф.М. Достоевского и И.А. Ильина [5, с. 83-135].

Надо сказать, что в рецензируемой книге С.И. Захарцев последовательно отражает собственный подход к философии права. Он считает эту дисциплину не юридической, а философско-специализированной наукой, размещающейся, условно говоря, между философией и общей теорией права. По его обоснованию, философия права - это философско-специализированная наука, предметом изучения которой являются основополагающие проблемы онтологии права, гносеологии права, аксиологии права, антропологии права, логики права, этики права, праксиологии права, правосознания [5, с. 272-273]. Этот подход не раз обосновывался в других монографиях автора $[6 ; 7 ; 8 ; 19]$. С.И. Захарцев также последователен в методологии права. Он убедителен в том, что юридической науке единая научная методология необходима. Такую функцию успешно выполняла и выполняет диалектика. Законы диалектики в праве действуют и являются основой для других научных методов. При этом уже отмечалось, что диалектика вовсе не забыта на Западе, а, напротив, достаточно активно используется. Автор уверен, что диалектический метод познания еще долго будет оставаться всеобщим, универсальным методом (методологической основой) для философии права, общей теории права и других правовых дисциплин [5, с. 290].

В контексте компрехендной теории права и философии особо значимы рассуждения С.И. Захарцева о запрограммированности общества и роли права в этом процессе. Мы согласным с автором, что в дореволюционной России при ее формировавшемся буржуазном капитализме жизнь каждого человека была четко запрограммирована и очерчена жесткими рамками. Что означает «жизнь запрограммирована»? Это значит, что уже с рождения человека сразу видно, как и в каких условиях он будет жить. Родился дворянином - будешь жить достойно, с медицинской помощью, образованием, статусной работой. А родился в семье крепостных - навсегда будешь рабом! Вырываться из крепостных удавалось единицам! Крепостное право в 1861 году вроде бы отменено. Но эта отмена, по большому счету, поменяла не так много. Конечно, избавление от рабства - это хорошо. Но указанная формальная отмена не принесла бывшим крепостным средств к существованию. Поэтому все равно у богатых жизнь нацелена на пополнение богатства, широкое образование и возможность стать кем хочешь и кем сможешь. Бедные слои населения России опять же очутились в жестком и узком коридоре: у них при формально задекларированных правах не появилось возможности получить пропитание, работу, образование, медицинскую помощь и т. д. Поэтому они с рождения были приучены к полунищете, голоду и прислуживанию богатым. И в таком коридоре им необходимо было существовать всю жизнь до смерти, без права выбора. Вырваться из коридора опять же удалось мало кому. Таким образом, жизнь сразу запрограммирована и очерчена [5, с. 147].

С.И. Захарцев верно отметил, что при рабовладельческом строе эти коридоры обеспечивались насилием. По мере развития человечества обеспечение таких оград стало осуществляться методами не столь жестокими, чем при рабовладельческом строе, но отнюдь не менее жесткими и циничными по своей сути. Так, в буржуазно-капиталистическом обществе жизненный коридор человека стала жестко очерчивать экономика. Экономика стала диктовать (не просто определять, а именно диктовать!) место человека в обществе. И это место стало банально зависеть от наличия или отсутствия у человека денежных средств. Программировала жизнь людей относительно небольшая прослойка власть имущих.

Мы много рассуждали с С.И. Захарцевым о том, что в настоящее время экономика обеспечивает жизненные коридоры человека и запрограммированность еще более цивилизованно - через образование! В подтверждение наших слов приведем понятный пример. Если у человека денег на образование нет, то человек его и не получит. Закончит обязательных восемь классов и устроится на работу грузчиком или типа того. Если у человека или его родителей хватило денег только на среднее образование, то эффект будет примерно таким же. Разве что он может закончить колледж, профессиональное училище и стать квалифицированным рабочим, техническим работником в организации и т. д. Устроиться на хорошо оплачиваемую работу может только человек, имеющий высшее образование, причем престижное и востребованное. Однако такое образование в абсолютном большинстве стран является платным. Если у человека нет денег, чтобы заплатить за высшее образование, то у него не будет и хорошо оплачиваемой работы. Причем в так называемых цивилизованных высокоразвитых странах проводится политика, чтобы, во-первых, высшее образование стоило не символических, а серьезных денег и, во-вторых, количество вузов и, соответственно, людей, имеющих высшее образование, было относительно небольшим. Иными словами, количество хорошо образованных людей является регулируемым (обратите на это внимание). Для 
всех остальных людей жизнь четко запрограммирована, каждый в своем коридоре. При этом и наличие высшего образования не всегда избавляет от «своего коридора». Вырваться из него могут единицы, как правило, хорошие артисты или спортсмены. Такая обстановка (с нюансами для каждой страны) имеется во всех современных капиталистических демократических государствах. Кроме этого, как верно сказано в книге, имеется также и другое явление, которое отдельные исследователи путают с подлинной свободой и справедливостью: когда в программе общественной жизни для человека заложен относительно неплохой уровень социального обеспечения. При такой ситуации специалист (служащий, рабочий, крестьянин и др.) получает сносную зарплату, более-менее удовлетворительную пенсию, терпимые социальные гарантии. Этот человек тоже выполняет свою роль и идет своим строго запрограммированным жизненным коридором (из которого также очень трудно выйти), но он удовлетворен в социальном плане и не думает о переменах. А чтобы человек не думал о возможных переменах в жизни, справедливости, честности, ему дают усеченное образование. Это образование может быть и высшим, но весьма узким, не приучающим думать и не включающим философские и нравственные ценности. Описанный выше тип жизненного коридора нередко называют «средним классом» [5, с. 148-149].

Далее в монографии правильно указывается, что в СССР среднее образование было, во-первых, бесплатным, во-вторых, обязательным, в-третьих, фундаментальным и даже близким к зарубежному высшему, в-четвертых, одинаковым, т. е. и в центральных школах Москвы, и в дальних уголках страны учили одинаково. Возможно, что в Москве уровень и был чуть выше, но это не мешало детям из сельских школ поступать в столичные престижные вузы. Поступали все, кто понастоящему хотел. Высшее образование было также бесплатным и фундаментальным. Такого среднего и высшего образования, как в СССР, не было нигде в мире. Сейчас советское образование развалено! При этом автор обращает внимание, что при переходе к капиталистической системе отношений в современной России в первую очередь развалили и разрушили систему образования. Помните расхожий афоризм: образованный и нашедший себя человек теряет зависимость от чужих мнений. Сейчас образованность не нужна. Нужна, как констатирует автор, программируемость и предсказуемость. Российское общество стали программировать с образования [5, с. 151].

В течение последних примерно пятидесяти лет в зарубежных странах, а теперь и в России получают высшее образование в кредит. То есть с совершеннолетия залезают в кредиты и затем их выплачивают. При этом современные российские вузы как один проводят политику по сокращению бюджетных, бесплатных мест. Соответственно, люди с молодости становятся еще более экономически подконтрольными и зависимыми. Ведь человеком, имеющим долги, всегда легче управлять. А если еще вспомнить кредиты на жилье, на автотранспорт, на медицинские операции... Одним словом, все направлено на то, чтобы у человека всю сознательную жизнь имелись долги, а он постоянно работал для их погашения.
Далее С.И. Захарцев задумался о роли права и закона в запрограммированном обществе. По его справедливому мнению, роль права и закона в таком обществе связана, как минимум, с двумя плоскостями. Первая плоскость: декларирование всеобщего равенства, абсолютного равенства между высшим чиновником и рабочим, миллионером и бедным крестьянином, бизнесменом и школьным учителем. Другая плоскость права и закона связана с тем, чтобы с их регламентацией рабочий тем не менее оставался рабочим, крестьянин - крестьянином, а миллионер - миллионером. Обеспечивают эти процессы нормативно-правовые акты. Иными словами, роль права в программируемом обществе связана с обеспечением нормального существования тех, кто это общество программирует, то есть тех, кому принадлежит реальная власть [5, с. 152-153].

В настоящее время в конституциях почти всех государств декларируются обширные естественные права человека. К ним относятся право на жизнь, на медицинскую помощь, на образование, на труд, на отдых, на пенсионное обеспечение и т. д. Кроме того, в рамках запрограммированности и своего жизненного коридора человек может быть достаточно свободен. Хочешь - покупай или не покупай, заводи или выкидывай, вступай в брак или нет, голосуй или игнорируй и пр. Закрепление широких прав, конечно, является большим шагом вперед по растущей цивилизованности и разумности всего человечества. Правовой прогресс, конечно, имеет место быть, о чем мы не раз писали [13, с. $171-188 ; 14$, c. $175-192 ; 15$, с. 20-35]. Раба уже не считают вещью, женщины и мужчины наделены равными правами и т. д. Но надо хорошо понимать, что все эти права и дозволения - только в пределах своего коридора, рамки которого жестко очерчены образованием и имеющимися финансами.

И более того: всегда следует помнить, что многие декларируемые права финансово не обеспечены. Хорошо, например, что есть право на труд. Однако обеспечивать работой и заработком никто не обязан. Сиди со своим правом и голодай. Прекрасно, что каждый имеет право на медицинскую помощь. Но эта помощь будет оказана ему только в том объеме, насколько у конкретного человека хватит денежных средств. Ярким подтверждением таких слов стала политика западных государств по отношению к своим пожилым жителям, заболевшим коронавирусной инфекцией. Инфицированных пожилых людей, не могущих хорошо оплатить лечение, просто стали свозить в хосписы, где они без оказания помощи умирали. В запрограммированной жизни этих несчастных людей изначально никто не планировал бороться за их здоровье [5, с. 154].

Проблема запрограммированности общества интересным образом пересекается с проблемой манипулирования сознанием с помощью информационных технологий, а также опасностью биологических экспериментов над человеком. За последний год в России выпущено три значимые книги, посвященные указанным проблемам. Это труд Т.Я. Хабриевой и Н.Н. Черногора «Будущее права. Наследие академика В.С. Степина и юридическая наука», монография Ю.Н. Жданова, С.К. Кузнецова и В.С. Овчинского «COVID-19: преступность, кибербезопасность, общество, полиция» и рецензируемая книга 
С.И. Захарцева $[4 ; 18]$. В этих работах названные ученые, каждый по-своему и со своей стороны, но объективно и принципиально рассмотрели опасности бесконтрольного внедрения различных информационных технологий и биоэкспериментов.

Для самого автора мы считаем необходимым и далее развивать исследования указанных новейших и крайне актуальных проблем современности.

У всего мирового сообщества вызвала интерес приведенная в книге и разрабатываемая С.И. Захарцевым с нашим участием гипотеза катаклизмов и круговорота жизни на Земле. Об этой гипотезе задумались не только философы, юристы и историки, но и физики, химики, врачи. Наблюдаемая пандемия COVID-19 подтвердила многие опасения и предположения автора, в том числе в части неконтролируемого развития современных биотехнологий и информационного насилия. Названным проблемам в книге посвящена отдельная глава [5, с. 291-329].

Мы поддерживаем то, что ученый не просто пишет о существовании рисков для всего человечества, но своими многочисленными публикациями привлекает к этой потенциальной опасности особое внимание, тем самым борясь с ней.

Книга С.И. Захарцева вышла в 2021 году и сразу стала заметной. Известные специалисты по теории и философии права высоко оценили ее, а некоторые и опубликовали рецензии [1, с. 248-251; 2, с. 217-232]. Монографией заинтересовались и за рубежом. Например, наши коллеги из Академии наук Таджикистана тоже опубликовали на нее положительную рецензию под названием «Новая книга известного российского философа права» [17, с. 187-195].

В контексте последних слов мы бы хотели обратить внимание уважаемого С.И. Захарцева на то, что в книге надо больше внимания уделять российскому суверенитету и российской суверенной философии права, более рельефно отражать самобытность русской философско-правовой идеологии. Тем более, что подобные работы у нас есть.

Сделанное замечание, однако, не влияет на высокую положительную оценку книги. Она фундаментальна, содержит много интересных и актуальных идей.

Мы рекомендуем монографию научным и педагогическим работникам юридических, философских и психологических вузов, студенчеству. Она будет полезна практическим работникам. А разделы, связанные с разъяснением опасности биологических и информационных экспериментов над человеком, а также гипотезой катаклизмов и круговорота жизни на Земле советуем прочитать всем.

Желаем уважаемому Сергею Ивановичу Захарцеву новых солидных книг и научных побед!

\section{Литература}

1. Баранов В.М., Баранова М.В. Инновационная трактовка права. Рецензия на монографию С.И. Захарцева «Право: новые идеи и прочтения» (М. : Юрлитинформ, 2021. 440 с.) // Юридическая наука и практика: Вестник Нижегородской академии МВД России. 2021. № 2 (54). C. $248-251$.

2. Галиев Ф.Х., Исмагилов Р.Ф., Сальников М.В. Актуальные проблемы науки о праве. Рецензия-размышления на монографию С.И. Захарцева «Право: новые идеи и прочтения. М. : Юрлитинформ, 2021. 440 с» // Правовое государство: теория и практика. 2021. № 2 (64). С. $217-232$. DOI: $10.33184 /$ pravgos-2021.2.18.

3. Гегель Г.В.Ф. Философия права / пер. с нем.; ред. и сост. Д.А. Керимов, В.С. Нерсесянц; авт. вступ. ст. и примеч. В.С. Нерсесянц. М. : Мысль, $1990.524 \mathrm{c}$.

4. Жданов Ю.Н., Кузнецов К.С., Овчинский В.С. COVID-19: преступность, кибербезопасность, общество, полиция; вступ. статья А.Л. Кудрина. М. : Международные отношения, 2021. 448 с.

5. Захарцев С.И. Право: новые идеи и прочтения : монография. М. : Юрлитинформ, 2021. 440 c. DOI: $10.17513 / \mathrm{np} .453$.

6. Захарцев С.И. Некоторые проблемы теории и философии права : монография / Под ред. В.П. Сальникова. М. : Норма, 2014. 208 с. DOI: $10.17513 /$ np.468.

7. Захарцев С.И., Сальников В.П. Философия. Философия права. Юридическая наука : монография. М. : Юрлитинформ, 2015. 264 с. DOI: $10.17513 / \mathrm{np} .454$.

8. Захарцев С.И., Сальников В.П. Философия и юридическая наука : монография. М. : Юрлитинформ, 2019. 424 с. DOI: 10.17513/np.491 .

9. Захарцев С.И., Масленников Д.В., Сальников В.П. Логос права: Парменид - Гегель - Достоевский. К вопросу о спекулятивно-логических основаниях метафизики права : монография. М. : Юрлитинформ, 2019. 376 с. DOI: 10.17513/np.467 .

10. Захарцев С.И., Сальников В.П. Компрехендная теория познания права // Юридическая наука: история и современность. 2015 . № 8. С. $11-26$.

11. Захарцев С.И., Сальников В.П. Компрехендная теория познания права // Мониторинг правоприменения. 2019. № 4 (33). С. 4-13. DOI: 10.21681/2226-0692-2019-4-04-13 .

12. Захарцев С.И., Сальников В.П. Пробелы в праве - грань компрехендной теории его познания // Пробелы в позитивном праве: доктрина и практика: материалы VI Международной научной конференции теоретиков права «Пробелы в позитивном праве: доктрина и практика» (Москва, 20-21 февраля 2020 г.) / Т.Я. Хабриева, С.В. Липень, В.В. Лазарев и др.; отв. ред. Н.Н. Черногор. М. : ИД «Юриспруденция», 2021. C. $93-103$.

13. Захарцев С.И., Сальников В.П. Правовой прогресс - новая философско-правовая дефиниция // Мир политики и социологии. 2016. № 4. С. $171-188$.

14. Захарцев С.И., Сальников В.П. Правовой прогресс как актуальная философско-правовая проблема // Юридическая наука: история и современность. 2016. № 9. С. 175-192.

15. Захарцев С.И., Сальников В.П. Правовой прогресс: новое направление исследования права // Теория государства и права. 2017. № 2 . С. 20 - 35. 
16. Идея свободы. Право. Мораль (классическая и постклассическая философия права) : монография / Ананских И.А., Грибов И.Н., Захарцев С.И., Зорина Н.В., Исмагилов И.Р., Клименко О.А., Лежнева О.Ю., Мазурин С.Ф., Маков Б.В., Масленников Д.В., Мирзоев И.К., Петров И.А., Поливко Е.А., Прокофьев К.Г., Пылева О.В., Сальников В.П., Сальников М.В., Чудин-Курган Ф.О.; под ред. С.И. Захарцева. М. : Юрлитинформ, 2020. 288 c.

17. Маджидзода Дж.3., (Зоиров Дж.М.), Шарофзода Р.Ш. Новая книга известного российского философа права. Рецензия на монографию С.И. Захарцева «Право: новые идеи и прочтения». М. : Юрлитинформ, 2021. 440 с. // Правовая жизнь. № 1 (33). 2021. С. 187-195.

18. Хабриева Т.Я., Черногор Н.Н. Будущее права. Наследие академика В.С. Степина и юридическая наука. М. : ИНФРА-M, 2020.176 с. DOI: $10.12737 / 1112960$.

19. Zakhartsev S.I., Salnikov V.P. The Philosophy of Law and Legal Science. Newcastle upon Tyne: Cambridge Scholars Publishing, 2018. 270 p. DOI: $10.17513 /$ np. 452 .

20. Zakhartsev S.I., Maslennikov D.V., Salnikov V.P. The Logos of Law: Parmenides - Hegel - Dostoevsky. The Speculative and Logical Foundations of the Metaphysics of Law. London: Europe Books. 2021. 450 p. DOI: 10.17513/np.490 .

\section{ReView of the Monograph by Sergei ZakhartseV "LAW: NEW IDEAS AND READINGS"}

\section{Sal'nikov4 , A. Khabibulin ${ }^{5}$ A. Chislov ${ }^{6}$}

We (autors) are among those scholars who devoted their life to studying the theory and philosophy of law. Of course, we know the works of our fellow scholars and keep track of their new publications and ideas.

At the same time there are not so many new works. That is why we were genuinely pleased when still another monograph by S. Zakhartsev entitled "Law: New Ideas and Readings" [5] was published in 2021, all the more so since the esteemed author is our long-time friend and co-author, and the development of many ideas set forth in the book was started by us jointly.

The review is dedicated to this book.

\section{References}

1. Baranov V.M., Baranova M.V. Innovatsionnaia traktovka prava. Retsenziia na monografiiu S.I. Zakhartseva "Pravo: novye idei i prochteniia” (M. : Iurlitinform, 2021. 440 pp.). Iuridicheskaia nauka i praktika: Vestnik Nizhegorodskoi akademii MVD Rossii, 2021, No. 2 (54), pp. 248-251.

2. Galiev F.Kh., Ismagilov R.F., Sal'nikov M.V. Aktual'nye problemy nauki o prave. Retsenziia-razmyshleniia na monografiiu S.I. Zakhartseva "Pravo: novye idei i prochteniia" (M. : Iurlitinform, 2021. 440 pp.). Pravovoe gosudarstvo: teoriia i praktika, 2021, No. 2(64), pp. 217-232. DOI: 10.33184/pravgos-2021.2.18 .

3. Gegel' G.V.F. Filosofiia prava. Per. s nem. Red. i sost. D.A. Kerimov, V.S. Nersesiants, avt. vstup. st. i primech. V.S. Nersesiants. M. : Mysl', 1990. 524 pp.

4. Zhdanov Iu.N., Kuznetsov K.S., Ovchinskii V.S. COVID-19: prestupnost', kiberbezopasnost', obshchestvo, politsiia, vstup. stat'ia A.L. Kudrina. M. : Mezhdunarodnye otnosheniia, 2021. 448 pp.

5. Zakhartsev S.I. Pravo: novye idei i prochteniia : monografiia. M. : Iurlitinform, 2021. 440 pp. DOI: 10.17513/np.453 .

6. Zakhartsev S.I. Nekotorye problemy teorii i filosofii prava : monografiia. Pod red. V.P. Sal'nikova. M. : Norma, 2014.208 pp. DOI: 10.17513/np.468.

7. Zakhartsev S.I., Sal'nikov V.P. Filosofiia. Filosofiia prava. Iuridicheskaia nauka : monografiia. M. : Iurlitinform, 2015. 264 pp. DOI: 10.17513/np.454 .

8. Zakhartsev S.I., Sal'nikov V.P. Filosofiia i iuridicheskaia nauka : monografiia. M. : Iurlitinform, 2019. 424 pp. DOI: $10.17513 / n p .491$.

4 Viktor Sal'nikov, Dr.Sc. (Law), Professor, Academician of the Russian Academy of Natural Sciences, Editor-in-Chief of the Journal "Legal Science: History and the Present", Counsellor at the Rector's Office of the Russian Christian Humanitarian Academy, Meritorious Scientist of the Russian Federation, Honorary Worker of Higher Professional Education of the Russian Federation, Saint Petersburg, Russian Federation.

E-mail: fonduniver@bk.ru

5 Alik Khabibulin, Dr.Sc. (Law), Professor, Head of the Department of Economic and Financial Investigations of the Higher School of Government Audit (faculty) of the Lomonosov Moscow State University, Professor at the Department of Theory of State \& Law and Politology of the Faculty of Law of the Lomonosov Moscow State University, Meritorious Lawyer of the Republic of Bashkortostan, Moscow, Russian Federation. E-mail: 21alik@mail.ru

${ }^{6}$ Aleksandr Chislov, Dr.Sc. (Law), Professor, Professor at the Department of Staff and Moral-cum-Psychological Support for the Activities of Bodies of Internal Affairs of the Tyumen Institute for Advanced Training of Employees of the Ministry of Internal Affairs of Russia, Tyumen, Russian Federation. E-mail: 944343@gmail.com 
9. Zakhartsev S.I., Maslennikov D.V., Sal'nikov V.P. Logos prava: Parmenid -- Gegel' -- Dostoevskii. K voprosu o spekuliativnologicheskikh osnovaniiakh metafiziki prava : monografiia. M. : Iurlitinform, 2019. 376 pp. DOI: 10.17513/np.467 .

10. Zakhartsev S.I., Sal'nikov V.P. Komprekhendnaia teoriia poznaniia prava. Iuridicheskaia nauka: istoriia i sovremennost', 2015, No. 8, pp. 11-26.

11. Zakhartsev S.I., Sal'nikov V.P. Komprekhendnaia teoriia poznaniia prava. Monitoring pravoprimeneniia, 2019, No. 4 (33), pp. 4-13. DOI: 10.21681/2226-0692-2019-4-04-13 .

12. Zakhartsev S.I., Sal'nikov V.P. Probely v prave -- gran' komprekhendnoi teorii ego poznaniia. Probely v pozitivnom prave: doktrina i praktika: materialy VI Mezhdunarodnoi nauchnoi konferentsii teoretikov prava "Probely v pozitivnom prave: doktrina i praktika" (Moskva, 20-21 fevralia 2020 g.). T.Ia. Khabrieva, S.V. Lipen', V.V. Lazarev i dr., otv. red. N.N. Chernogor. M. : ID “Iurisprudentsiia”, 2021, pp. 93-103.

13. Zakhartsev S.I., Sal'nikov V.P. Pravovoi progress - novaia filosofsko-pravovaia definitsiia. Mir politiki i sotsiologii, 2016, No. 4, pp. 171-188.

14. Zakhartsev S.I., Sal'nikov V.P. Pravovoi progress kak aktual'naia filosofsko-pravovaia problema. Iuridicheskaia nauka: istoriia i sovremennost', 2016, No. 9, pp. 175-192.

15. Zakhartsev S.I., Sal'nikov V.P. Pravovoi progress: novoe napravlenie issledovaniia prava. Teoriia gosudarstva i prava, 2017, No. 2, pp. 20-35.

16. Ideia svobody. Pravo. Moral' (klassicheskaia i postklassicheskaia filosofiia prava): monografiia. Ananskikh I.A., Gribov I.N., Zakhartsev S.I., Zorina N.V., Ismagilov I.R., Klimenko O.A., Lezhneva O.Iu., Mazurin S.F., Makov B.V., Maslennikov D.V., Mirzoev I.K., Petrov I.A., Polivko E.A., Prokof'ev K.G., Pyleva O.V., Sal'nikov V.P., Sal'nikov M.V., Chudin-Kurgan F.O., pod red. S.I. Zakhartseva. M. : Iurlitinform, 2020. $288 \mathrm{pp}$.

17. Madzhidzoda Dzh.Z., (Zoirov Dzh.M.), Sharofzoda R.Sh. Novaia kniga izvestnogo rossiiskogo filosofa prava. Retsenziia na monografiu S.I. Zakhartseva "Pravo: novye idei i prochteniia” (M. : Iurlitinform, 2021. 440 pp.). Pravovaia zhizn', No. 1 (33), 2021, pp. 187-195.

18. Khabrieva T.Ia., Chernogor N.N. Budushchee prava. Nasledie akademika V.S. Stepina i iuridicheskaia nauka. M. : INFRA-M, 2020. 176 pp. DOI: $10.12737 / 1112960$.

19. Zakhartsev S.I., Salnikov V.P. The Philosophy of Law and Legal Science. Newcastle upon Tyne: Cambridge Scholars Publishing, 2018. 270 p. DOI: $10.17513 /$ np. 452 .

20. Zakhartsev S.I., Maslennikov D.V., Salnikov V.P. The Logos of Law: Parmenides -- Hegel -- Dostoevsky. The Speculative and Logical Foundations of the Metaphysics of Law. London: Europe Books, 2021. 450 p. DOI: 10.17513/np.490 . 


\title{
ДОКЛАД \\ О РЕЗУЛЬТАТАХ МОНИТОРИНГА ПРАВОПРИМЕНЕНИЯ В РОССИЙСКОЙ ФедерацИИ ЗА 2020 год
}

\begin{abstract}
Ключевые слова: Конституционный Суд Российской Федерации, Европейский Суд по правам человека, капитальный ремонт, общее имущество, культурное наследие, леса, безнадзорность, несовершеннолетние, социально опасное положение, антиконкурентные соглашения, таможенное регулирование, налогообложение, медицинские изделия.
\end{abstract}

Аннотация. Публикация служит обеспечению государственной политики, основанной на принципе открытости и доступности правовой информации. В Докладе обобщена информация о состоянии законодательства и практике его применения в самых разных сферах жизнедеятельности, позволяющем увидеть тенденции развития, учитывать мнения всех субъектов общественных отношений. Мониторинг правоприменения является для современной России важным видом деятельности, позволяющем обеспечивать совершенствование законодательства.

DOI: 10.21681/2226-0692-4-99-107

\section{Введение}

Д оклад о результатах мониторинга правоприменения в Российской Федерации за 2020 год подготовлен по итогам реализации федеральными органами исполнительной власти и органами государственной власти субъектов Российской Федерации Указа Президента Российской Федерации от 20 мая 2011 г. № 657 «О мониторинге правоприменения в Российской Федерации» (далее - Указ № 657).

Мониторинг правоприменения в Российской Федерации проведен в соответствии с планом мониторинга правоприменения в Российской Федерации на 2020 год (утвержден распоряжением Правительства Российской Федерации от 31 августа 2019 г. № 1951-р) и методикой осуществления мониторинга правоприменения в Российской Федерации (утверждена постановлением Правительства Российской Федерации от 19 августа 2011 г. № 694 «Об утверждении методики осуществления мониторинга правоприменения в Российской Федерации»).

В ходе изучения правоприменительной практики использовались: информация федеральных органов исполнительной власти, органов исполнительной власти субъектов Российской Федерации и Генеральной прокуратуры Российской Федерации о применении нормативных правовых актов, статистическая информация, обращения граждан, вступившие в силу судебные акты, разъяснения Верховного Суда Российской Федерации по вопросам судебной практики, а также сведения, поступившие от научных, образовательных и общественных организаций, от представителей бизнеса и правозащитных организаций.

В частности, использовалась информация Института государства и права Российской академии наук, Государственного университета по землеустройству, Исследовательского центра частного права имени С.С. Алексеева при Президенте Российской Федерации, Казанского (Приволжского) федерального университета, Московского государственного юриди- ческого университета имени О.Е. Кутафина, СанктПетербургского государственного университета, Российской академии народного хозяйства и государственной службы при Президенте Российской Федерации, Российского государственного университета правосудия, Уральского государственного юридического университета, Ассоциации региональных операторов капитального ремонта многоквартирных домов (АРОКР), ассоциации “Капитальный ремонт и строительство" (СРО “КРС”), Национального объединения изыскателей и проектировщиков (НОПРИЗ), Фонда содействия реформированию жилищно-коммунального хозяйства, Фонда капитального ремонта многоквартирных домов города Москвы, ассоциации “Некоммерческое партнерство “Объединение корпоративных юристов”, юридической фирмы “АЛРУД”.

В докладе содержатся основанные на анализе правоприменительной практики предложения о необходимости принятия нормативных правовых актов Российской Федерации, о мерах по повышению эффективности правоприменения.

\section{I. Мониторинг выполнения решений Конституционного Суда Российской Федерации}

В соответствии с Указом № 657 Минюст России во взаимодействии с Конституционным Судом Российской Федерации, палатами Федерального Собрания Российской Федерации, Аппаратом Правительства Российской Федерации, а также с федеральными органами исполнительной власти осуществляет мониторинг правоприменения в целях исполнения решений Конституционного Суда Российской Федерации, в связи с которыми необходимо принятие (издание), изменение или признание утратившими силу (отмена) законодательных и иных нормативных правовых актов Российской Федерации. 
С 1 января 1992 г. по 25 августа 2021 г. Конституционный Суд Российской Федерации принял 298 постановлений (в том числе в 2020 году - 24 постановления, за истекший период 2021 года - 16 постановлений), требующих исполнения, — о признании нормативного акта не соответствующим Конституции Российской Федерации полностью или частично либо о признании нормативного акта или отдельных его положений соответствующими Конституции Российской Федерации, но при этом из данного Конституционным Судом Российской Федерации истолкования вытекает необходимость устранения пробелов или противоречий в правовом регулировании.

С 1992 года исполнено 262 решения Конституционного Суда Российской Федерации (в том числе в 2020 году - 16 постановлений, за истекший период 2021 года - 15 постановлений).

По состоянию на 25 августа 2021 г. требуется исполнение 37 постановлений Конституционного Суда Российской Федерации. В целях исполнения 20 постановлений Правительство Российской Федерации внесло в Государственную Думу Федерального Собрания Российской Федерации (далее - Государственная Дума) законопроекты либо поддержало проекты федеральных законов, разработанные иными субъектами права законодательной инициативы, в отношении 17 постановлений федеральными органами исполнительной власти ведется необходимая работа.

Актуальная информация о реализации постановлений Конституционного Суда Российской Федерации размещена на официальном сайте Минюста России в информационно-телекоммуникационной сети «Интернет» (https://minjust.gov.ru/ru/pages/monitoring-pravoprimeneniya-reshenij-konstitucionnogo-suda-rossijskojfederacii).

\section{II. Мониторинг выполнения постановлений Европейского Суда по правам человека}

В соответствии с Указом № 657 Минюстом России во взаимодействии с компетентными органами осуществляется мониторинг правоприменения в целях выполнения постановлений Европейского Суда по правам человека (далее - Европейский Суд), в связи с которыми необходимо принятие (издание), изменение или признание утратившими силу (отмена) законодательных и иных нормативных правовых актов Российской Федерации.

В целях выполнения ряда постановлений Европейского Суда продолжается деятельность по внесению изменений в законодательство Российской Федерации (приложение № 1).

Так, на рассмотрении в Государственной Думе находятся 7 законопроектов, разработанных с учетом выводов Европейского Суда, изложенных в постановлениях, объединенных в группы дел «Гарабаев» (Garabayev), «Ракевич» (Rakevich), «Ким» (Kim), «Свинаренко и Сляднев» (Svinarenko and Slyadnev), «Евдокимов» (Yevdokimov), «Володина» (Volodina); в постановлении от 19 февраля 2013 г. по делу «Ефимова против Российской Федерации» (Yefimova v. Russia), жалоба № 39786/09; в постановлении от 23 марта 2016 г. по делу «Блохин против Российской Федерации» (Blokhin v. Russia), жалоба № 47152/06; в постановлении от 14 февраля
2017 г. по делу “Алланазарова против Российской Федерации” (Allanazarova v. Russia), жалоба № 46721/15.

Федеральными органами исполнительной власти организована подготовка проектов нормативных правовых актов в связи с постановлениями Европейского Суда, бъединенными в группы дел “Назаренко” (Nazarenko), "Карелин” (Karelin), “Гулиев” (Guliyev), “Володина” (Volodina); с постановлением Европейского Суда от 18 апреля 2013 г. по делу «Агеевы против Российской Федерации» (Ageyevy v. Russia), жалоба № 7075/10; с постановлением от 19 ноября 2015 г. по делу «Михайлова против Российской Федерации» (Mikhailova v. Russia), жалоба № 46998/08; с постановлением от 14 февраля 2017 г. по делу «Алланазарова против Российской Федерации» (Allanazarova v. Russia), жалоба № 46721/15.

Федеральным органам исполнительной власти необходимо также проработать вопросы о достаточности принятых мер или о внесении изменений в законодательство Российской Федерации (с учетом актуальной практики Конституционного Суда Российской Федерации, Европейского Суда, а также складывающейся правоприменительной практики государственных органов и судов) в целях реализации правовых позиций Европейского Суда, изложенных в постановлениях Европейского Суда, объединенных в группы дел «Гулиев» (Guliyev), «Ваньян» (Vanyan), «Евдокимов» (Yevdokimov), «Лашманкин» (Lashmankin), «Лю» (Liu), «Горлов» (Gorlov), «Володина» (Volodina), «H.T.» (N.T.); в постановлении от 13 декабря 2011 г. по делу «Васильев и Ковтун против Российской Федерации» (Vasilyev and Kovtun v. Russia), жалоба № 13703/04; в пилотном постановлении от 10 января 2012 г. по делу «Ананьев и другие против Российской Федерации» (Ananyev and Others v. Russia), жалобы № 42525/07, № 60800/08; в постановлении от 23 марта 2016 г. по делу «Блохин против Российской Федерации» (Blokhin v. Russia), жалоба № 47152/06; в постановлении от 31 января 2017 г. по делу «Вахитов и другие против Российской Федерации» (Vakhitov and Others v. Russia), жалобы № 18232/11, № 42945/11, № 31596/14; в постановлении от 14 февраля 2017 г. по делу «Алланазарова против Российской Федерации» (Allanazarova v. Russia), жалоба № 46721/15; в постановлении от 27 марта 2018 г. по делу «Беркович и другие против Российской Федерации» (Berkovich and Others v. Russia), жалоба № 5871/07.

\section{III. Мониторинг правоприменения по отраслям законодательства Российской Федерации}

\section{1. Организация проведения капитального ремонта общего имущества в многоквартирных домах}

Согласно частям 1 и 2 статьи 40 Конституции Российской Федерации каждый имеет право на жилище, органы государственной власти и органы местного самоуправления создают условия для реализации этого права. Жилищное законодательство находится в совместном ведении Российской Федерации и субъектов Российской Федерации (пункт «к» части 1 статьи 72 Конституции Российской Федерации).

Основным нормативным правовым актом, регулирующим отношения в сфере организации проведения 
капитального ремонта общего имущества в многоквартирных домах, является Жилищный кодекс Российской Федерации (далее - ЖК РФ).

Органы государственной власти и органы местного самоуправления в пределах своих полномочий обеспечивают условия для осуществления гражданами права на жилище, в том числе организуют обеспечение своевременного проведения капитального ремонта общего имущества в многоквартирных домах за счет взносов собственников помещений в таких домах на капитальный ремонт общего имущества в многоквартирных домах, бюджетных средств и иных не запрещенных законом источников финансирования (пункт $6^{1}$ статьи 2 ЖК РФ).

В ходе мониторинга правоприменения выявлены проблемы правового регулирования в сфере организации проведения капитального ремонта общего имущества в многоквартирных домах, решение которых требуется на федеральном законодательном уровне.

\section{1. Неполнота правового регулирования} понятия «многоквартирный дом»

Сохраняет актуальность проблема реализации программ капитального ремонта в субъектах Российской Федерации в связи с отсутствием в ЖК РФ понятия «многоквартирный дом», что на практике затрудняет формирование перечня объектов, подлежащих включению в программу капитального ремонта общего имущества в многоквартирных домах (далее также - капитальный ремонт). Информация об указанной проблеме была отражена в докладе о результатах мониторинга правоприменения в Российской Федерации за 2015 год.

В настоящее время Правительством Российской Федерации подготавливается к внесению в Государственную Думу проект федерального закона «О внесении изменений в Градостроительный кодекс Российской Федерации и отдельные законодательные акты Российской Федерации».

Законопроект направлен на устранение правовой неопределенности, возникающей при отнесении здания к многоквартирному дому или к дому блокированной застройки, выявленной по результатам анализа положений законодательства и практики его применения.

Законопроектом предусматривается определение понятий «многоквартирный дом», «дом блокированной застройки», которые необходимы для более точного и полного правового регулирования жилищных и градостроительных правоотношений и возникающих спорных вопросов.

Понятие «многоквартирный дом» вводится в ЖК РФ, а понятие «дом блокированной застройки» в Градостроительный кодекс Российской Федерации в соответствии с кругом правоотношений, регулируемых указанными кодифицированными актами.

1.2. Неполнота правового регулирования вопросов формирования региональных программ капитального ремонта и краткосрочных планов их реализации

Практика реализации региональных программ капитального ремонта общего имущества в многоквартирных домах показала, что сведения о техническом состоянии многоквартирных домов, на основании которых определяется очередность проведения капитального ремонта, не всегда соответствуют текущему техническому состоянию многоквартирного дома. Например, в региональной программе запланирован ремонт фасада, а в процессе подготовки дома к капитальному ремонту становится ясно, что требуется капитальный ремонт крыши.

При возникновении подобных ситуаций субъект Российской Федерации не имеет юридических оснований для внесения изменений в региональную программу капитального ремонта, предусматривающих перенос сроков проведения капитального ремонта на более поздний период, без наличия решения общего собрания собственников помещений в многоквартирном доме (часть 4 статьи 168 ЖК РФ).

В целях совершенствования системы капитального ремонта общего имущества в многоквартирных домах Минстроем России разрабатывается проект федерального закона «О внесении изменений в Жилищный кодекс Российской Федерации», которым в перечне работ по капитальному ремонту, осуществляемых за счет минимального взноса на капитальный ремонт, предлагается выделить как самостоятельный вид работ обследование технического состояния многоквартирного дома или его отдельных конструктивных элементов.

Проведение такого обследования позволит определить приоритетные виды работ по капитальному ремонту либо принять решение об отсутствии необходимости проведения капитального ремонта (в случае, если многоквартирный дом или его конструктивный элемент находится в нормативном состоянии) или об отсутствии целесообразности его проведения (в случае, если по результатам обследования установлено аварийное техническое состояние многоквартирного дома).

По результатам обследования технического состояния многоквартирного дома предлагается предоставить право субъектам Российской Федерации изменять сроки проведения капитального ремонта на основании заключения о результатах обследования, в том числе переносить срок выполнения работ по капитальному ремонту на более поздний период в случае, если определено, что проведение таких работ в установленный срок не требуется.

Принятие предлагаемых изменений позволит более эффективно использовать взносы на капитальный ремонт и повысить финансовую устойчивость региональных программ капитального ремонта.

1.3. Неполнота правового регулирования вопросов софинансирования работ по капитальному ремонту общего имущества в многоквартирных домах, являющихся объектами культурного наследия

В соответствии с Федеральным законом от 25 июня 2002 г. № 73-Ф3 «Об объектах культурного наследия (памятниках истории и культуры) народов Российской Федерации» (далее - Федеральный закон № 73-ФЗ) государственная охрана объектов культурного наследия (памятников истории и культуры) является одной из приоритетных задач органов государственной власти Российской Федерации, органов государственной власти субъектов Российской Федерации и органов местного самоуправления. 
Многоквартирные дома, являющиеся памятниками истории и культуры, представляют собой уникальную ценность и являются неотъемлемой частью всемирного культурного наследия (абзац второй преамбулы Федерального закона № 73-Ф3).

На практике стоимость проведения капитального ремонта общего имущества в многоквартирных домах, являющихся объектами культурного наследия, как правило, превышает предельную стоимость работ по капитальному ремонту.

По общему правилу превышение предельной стоимости работ по капитальному ремонту осуществляется за счет средств собственников в многоквартирном доме, уплачиваемых в виде взноса на капитальный ремонт сверх минимального размера такого взноса (часть 4 статьи 190 ЖК РФ).

Статьей 191 ЖК РФ предусмотрена возможность предоставления за счет средств федерального бюджета, средств бюджета субъекта Российской Федерации, местного бюджета финансовой поддержки при выполнении работ по капитальному ремонту. При этом обязанность по софинансированию таких работ в части превышения предельной стоимости в отношении многоквартирных домов, являющихся объектами культурного наследия, не установлена.

В целях решения данной проблемы депутатами Государственной Думы разработан проект федерального закона № 1180448-7 «О внесении изменений в Федеральный закон «Об объектах культурного наследия (памятниках истории и культуры) народов Российской Федерации» и Жилищный кодекс Российской Федерации», предусматривающий право органов публичной власти Российской Федерации оказывать финансовую поддержку в случае превышения размера предельной стоимости работ по капитальному ремонту общего имущества в многоквартирных домах - объектах культурного наследия за счет бюджетных средств с учетом историко-культурного значения таких объектов (федерального, регионального или местного значения).

Законопроектом также предусматривается, что работы по капитальному ремонту общего имущества в многоквартирном доме - объекте культурного наследия являются работами по сохранению такого дома как объекта культурного наследия в соответствии с Федеральным законом № 73-ФЗ.

\section{2. Использование, охрана, защита и воспроизводство лесов}

В соответствии с пунктом «к» части 1 статьи 72 Конституции Российской Федерации лесное законодательство находится в совместном ведении Российской Федерации и субъектов Российской Федерации.

Основными нормативными правовыми актами, регулирующими вопросы использования, охраны, защиты и воспроизводства лесов, являются Лесной кодекс Российской Федерации, иные федеральные законы, нормативные правовые акты Правительства Российской Федерации, федеральных органов исполнительной власти и органов государственной власти субъектов Российской Федерации.
В целях обеспечения пожарной безопасности в леcax, повышения безопасностиграждан иснижения рисков и угроз перехода ландшафтных (природных) пожаров на территории населенных пунктов принят Федеральный закон от 22 декабря 2020 г. № 454-Ф3 «О внесении изменений в отдельные законодательные акты Российской Федерации в части совершенствования деятельности в области пожарной безопасности», которым введены понятия «ландшафтный (природный) пожар» и «лесной пожар», разграничены полномочия между органами государственной власти и органами местного самоуправления при тушении таких пожаров. В частности, органы государственной власти субъектов Российской Федерации наделены полномочиями по организации тушения ландшафтных (природных) пожаров силами и средствами единой государственной системы предупреждения и ликвидации чрезвычайных ситуаций, а органы местного самоуправления муниципальных районов - полномочиями по обеспечению первичных мер пожарной безопасности в границах муниципальных районов, в том числе на межселенной территории, за границами городских и сельских населенных пунктов.

В 2021 году Правительством Российской Федерации утверждена Стратегия развития лесного комплекса Российской Федерации до 2030 года (распоряжение Правительства Российской Федерации от 11 февраля 2021 г. № 312-p).

Федеральным законом от 4 февраля 2021 г. № 3-Ф3 «О внесении изменений в Лесной кодекс Российской Федерации и отдельные законодательные акты Российской Федерации в части совершенствования правового регулирования лесных отношений» внесены системные изменения, связанные с цифровой трансформацией лесного хозяйства. В частности, с 1 января 2023 г. будет создана федеральная государственная информационная система лесного комплекса, которая позволит получать, обрабатывать, хранить и использовать актуальную информацию о состоянии лесов, об их количественных и качественных характеристиках, использовании, охране, защите и воспроизводстве. Вводятся разрешительные и отчетные документы по использованию лесов в электронной форме.

В ходе мониторинга правоприменения выявлены проблемы, которые планируется решить посредством принятия федеральных законов о внесении изменений в отдельные законодательные акты Российской Федерации и иные нормативные правовые акты Российской Федерации.

2.1. Противоречия федеральным законам, коллизии норм права в актах Правительства Российской Федерации, приказах Минприроды России и Рослесхоза, регулирующих вопросы использования, охраны, защиты и воспроизводства лесов

В связи с внесением комплексных изменений в Лесной кодекс Российской Федерации выявлена необходимость пересмотра большого количества актов Правительства Российской Федерации, приказов Минприроды России и Рослесхоза, содержащих коллизии норм права, внутренние противоречия, а также ссылки на утратившие силу нормативные правовые акты. 
Минприроды России совместно с Рослесхозом и заинтересованными федеральными органами исполнительной власти поручено провести работу по принятию новых нормативных правовых актов и приведению в соответствие с действующим законодательством Российской Федерации нормативных правовых актов Правительства Российской Федерации, приказов Минприроды России и Рослесхоза, регулирующих вопросы использования, охраны, защиты и воспроизводства лесов.

Указанная работа осуществляется в рамках подготовки пакета подзаконных нормативных правовых актов, направленных на реализацию федеральных законов от 4 февраля 2021 г. № 3-Ф3 «О внесении изменений в Лесной кодекс Российской Федерации и отдельные законодательные акты Российской Федерации в части совершенствования правового регулирования лесных отношений», от 2 июля 2021 г. № 301-Ф3 «О внесении изменений в Лесной кодекс Российской Федерации и отдельные законодательные акты Российской Федерации», от 2 июля 2021 г. № 302-Ф3 «О внесении изменений в Лесной кодекс Российской Федерации и отдельные законодательные акты Российской Федерации», от 2 июля 2021 г. № 303-Ф3 «О внесении изменений в Лесной кодекс Российской Федерации и отдельные законодательные акты Российской Федерации», от 2 июля 2021 г. № 304-Ф3 «О внесении изменений в Лесной кодекс Российской Федерации и статьи 14 и 16 Федерального закона «Об общих принципах организации местного самоуправления в Российской Федерации».

2.2. Неполнота правового регулирования вопросов включения границ лесопарковых зеленых поясов в Единый государственный реестр недвижимости

Необходимость включения границ лесопарковых зеленых поясов в Единый государственный реестр недвижимости в соответствии с законодательством Российской Федерации прямо предусмотрена пунктом 12 статьи $62^{2}$ Федерального закона от 10 января 2002 г. № 7-Ф3 «Об охране окружающей среды».

Вместе с тем по представленным данным в 50 субъектах Российской Федерации границы лесопарковых зеленых поясов не включены в Единый государственный реестр недвижимости.

Как показывает судебная практика ${ }^{1}$, регистрирующие органы направляют в органы государственной власти субъектов Российской Федерации уведомления о невозможности внесения сведений о границах лесопарковых зеленых поясов в Единый государственный реестр недвижимости в связи с тем, что внесение таких сведений не предусмотрено Федеральным законом от 13 июля 2015 г. № 218-Ф3 «О государственной регистрации недвижимости», определяющим состав сведений, подлежащих включению в реестр границ Единого государственного реестра недвижимости, а также ввиду того, что не определены правовой статус или правовой режим лесопарковых зеленых поясов, которые позволили бы отнести их, например, к зонам с особыми условиями

Например, решение Арбитражного суда Красноярского края от 10 декабря 2019 г. по делу № А33-27101/2019, постановление Арбитражного суда Восточно-Сибирского округа от 7 сентября 2020 г. № Ф02-4049/2020 по делу № А33-27101/2019. использования территорий. Так, пунктом 2 статьи $62^{4}$ Федерального закона от 10 января 2002 г. № 7-Ф3 «Об охране окружающей среды» предусмотрено установление ограниченного режима природопользования и иной хозяйственной деятельности и не предусмотрено установление ограничений в использовании земельных участков (пункт 2 статьи 104 Земельного кодекса Российской Федерации). Данные обстоятельства не позволяют включить лесопарковые зеленые пояса в установленный статьей 105 Земельного кодекса Российской Федерации перечень видов зон с особыми условиями использования территорий как отдельный вид таких зон.

В целях решения данной проблемы предлагается поручить Росреестру и Минприроды России разработать проект федерального закона «О внесении изменений в отдельные законодательные акты Российской Федерации», предусматривающий регламентацию вопросов включения границ лесопарковых зеленых поясов в Единый государственный реестр недвижимости) (приложение № 4).

\section{3. Профилактика безнадзорности и правонарушений несовершеннолетних}

Дети являются важнейшим приоритетом государственной политики России (часть 4 статьи $67^{1}$ Конституции Российской Федерации).

Основным нормативным правовым актом, регулирующим отношения в сфере профилактики безнадзорности и правонарушений несовершеннолетних, является Федеральный закон от 24 июня 1999 г. № 120-Ф3 «Об основах системы профилактики безнадзорности и правонарушений несовершеннолетних» (далее - Федеральный закон № 120-Ф3).

В ходе анализа законодательства и правоприменительной практики в этой сфере выявлена неполнота в правовом регулировании отдельных вопросов, которые предлагается проработать Минпросвещения России в рамках работы над проектом федерального закона «О защите прав несовершеннолетних и профилактике их антиобщественного и противоправного поведения».

3.1. Неполнота правового регулирования в сфере межведомственного взаимодействия органов и учреждений системы профилактики безнадзорности и правонарушений несовершеннолетних по ведению учета несовершеннолетних, находящихся в социально опасном положении

К органам и учреждениям системы профилактики безнадзорности и правонарушений несовершеннолетних относятся комиссии по делам несовершеннолетних и защите их прав, органы управления социальной защитой населения, федеральные органы государственной власти и органы государственной власти субъектов Российской Федерации, осуществляющие государственное управление в сфере образования, и органы местного самоуправления, осуществляющие управление в сфере образования, органы опеки и попечительства, органы по делам молодежи, органы управления здравоохранением, органы службы занятости, органы внутренних дел, учреждения уголовно-исполнительной системы, а также 
иные учреждения, находящиеся в ведении указанных органов (статья 4 Федерального закона № 120-Ф3).

В настоящее время органы и учреждения системы профилактики безнадзорности и правонарушений несовершеннолетних ведут самостоятельный учет несовершеннолетних, находящихся в социально опасном положении, например:

- учет правонарушений и антиобщественных действий несовершеннолетних, лиц, их совершивших, родителей и иных законных представителей несовершеннолетних, не исполняющих своих обязанностей по воспитанию, обучению и (или) содержанию несовершеннолетних и (или) отрицательно влияющих на их поведение либо жестоко обращающихся с ними;

- учет несовершеннолетних, не посещающих или систематически пропускающих по неуважительным причинам занятия в образовательных организациях.

Учет каждого из указанных видов ведется обособленно, орган или учреждение системы профилактики безнадзорности и правонарушений несовершеннолетних, в компетенции которого находится ведение учета одного вида, может получить необходимую ему информацию от другого органа или учреждения, осуществляющих учет иного вида, только посредством запроса. В связи с этим ведомства несвоевременно получают информацию о несовершеннолетних, находящихся в социально опасной ситуации.

Таким образом, несмотря на то, что в субъектах Российской Федерации приняты нормативные правовые акты о единых региональных банках данных безнадзорных и беспризорных несовершеннолетних и об их семьях, существует проблема в межведомственном взаимодействии и во взаимном информировании органов и учреждений системы профилактики безнадзорности и правонарушений несовершеннолетних, в том числе о поведении несовершеннолетнего, об условиях его жизни, о нарушении его прав и законных интересов.

В качестве решения данной проблемы предлагается создать федеральную информационную систему, содержащую информацию, сформированную органами и учреждениями системы профилактики безнадзорности и правонарушений несовершеннолетних.

3.2. Неполнота правового регулирования в сфере наставничества над несовершеннолетними, находящимися в социально опасном положении

Деятельность по профилактике безнадзорности и правонарушений несовершеннолетних основывается в том числе на принципе индивидуального подхода к несовершеннолетним (пункт 2 статьи 2 Федерального закона № 120-Ф3).

В целях проведения индивидуальной профилактической работы с несовершеннолетними и их семьями, находящимися в социально опасном положении, в субъектах Российской Федерации применяется институт наставничества.

Так, в ряде субъектов Российской Федерации (например, в Республике Калмыкия, в Костромской, Курской, Омской, Ульяновской областях и других субъектах Российской Федерации) приняты законы и иные нор- мативные правовые акты, регламентирующие деятельность наставников (общественных воспитателей) несовершеннолетних.

С учетом того, что в Федеральном законе № 120 Ф3 отсутствует понятие «наставник» и не предусмотрен порядок осуществления наставничества над несовершеннолетними, органы государственной власти субъектов Российской Федерации устанавливают требования к лицам, которые могут быть наставниками (общественными воспитателями) несовершеннолетних, порядок закрепления наставников (общественных воспитателей) за несовершеннолетними, а также их обязанности и требования к организации работы.

В целях совершенствования деятельности по профилактике безнадзорности и правонарушений несовершеннолетних предлагается на федеральном законодательном уровне определить понятие «наставник (общественный воспитатель) несовершеннолетнего», предусмотреть требования к указанным лицам и организации их деятельности в отношении несовершеннолетних, направленной на защиту прав детей, профилактику их антиобщественного и противоправного поведения.

\section{3. Неполнота правового регулирования} требований к составу комиссии по делам несовершеннолетних и ее членам

Комиссии по делам несовершеннолетних и защите их прав обеспечивают защиту прав и законных интересов несовершеннолетних.

При этом Федеральным законом № 120-Ф3 и Примерным положением о комиссиях по делам несовершеннолетних и защите их прав, утвержденным постановлением Правительства Российской Федерации от 6 ноября 2013 г. № 995, для участия в работе комиссии не предусмотрены какие-либо ограничения. На практике это приводит к тому, что членами комиссии могут стать лица, которых нельзя допускать к работе с несовершеннолетними. По информации Генеральной прокуратуры Российской Федерации, выявлены случаи участия в работе комиссии граждан, ранее привлекавшихся к уголовной ответственности за совершение преступлений, связанных с незаконным оборотом наркотических средств.

В связи с этим предлагается на федеральном законодательном уровне установить запрет на включение лиц, имеющих или имевших судимость, а также подвергавшихся уголовному преследованию, в состав комиссий по делам несовершеннолетних.

Аналогичное правовое регулирование предусмотрено статьей $351^{1}$ Трудового кодекса Российской Федерации, которой установлены ограничения для лиц, осуществляющих трудовую деятельность в сфере образования, воспитания, развития несовершеннолетних, организации их отдыха и оздоровления, медицинского обеспечения, социальной защиты и социального обслуживания, а также в сфере детско-юношеского спорта, культуры и искусства с участием несовершеннолетних.

Так, к указанной деятельности не допускаются лица, имеющие или имевшие судимость, а равно подвергавшиеся уголовному преследованию (за исключением лиц, уголовное преследование в отношении которых 
прекращено по реабилитирующим основаниям) за преступления против жизни и здоровья, свободы, чести и достоинства личности (за исключением незаконной госпитализации в медицинскую организацию, оказывающую психиатрическую помощь в стационарных условиях, и клеветы), половой неприкосновенности и половой свободы личности, против семьи и несовершеннолетних, здоровья населения и общественной нравственности, основ конституционного строя и безопасности государства, мира и безопасности человечества, против общественной безопасности (за исключением лиц, имевших судимость, которые могут быть допущены к педагогической деятельности при наличии решения комиссии по делам несовершеннолетних о допуске к трудовой деятельности), а также лица, имеющие неснятую или непогашенную судимость за иные умышленные тяжкие и особо тяжкие преступления.

\section{4. Противодействие антиконкурентным соглашениям}

Согласно части 2 статьи 34 Конституции Российской Федерации не допускается экономическая деятельность, направленная на монополизацию и недобросовестную конкуренцию.

Основным нормативным правовым актом в сфере противодействия антиконкурентным соглашениям является Федеральный закон от 26 июля 2006 г. № 135Ф3 «О защите конкуренции» (далее - Федеральный закон № 135-Ф3). Нормы об ответственности за заключение и (или) исполнение антиконкурентных соглашений предусмотрены в Кодексе Российской Федерации об административных правонарушениях и в Уголовном кодексе Российской Федерации.

Разъяснения относительно антиконкурентных соглашений содержатся в том числе в постановлении Пленума Верховного Суда Российской Федерации от 4 марта 2021 г. № 2 «О некоторых вопросах, возникающих в связи с применением судами антимонопольного законодательства».

В ходе мониторинга правоприменения выявлены проблемы, которые планируется решить посредством принятия федеральных законов и разъяснения действующих правовых норм.

4.1. Неполнота правового регулирования административной ответственности за заключение и (или) исполнение антиконкурентных соглашений с использованием программ для электронно-вычислительных машин

В настоящее время программы для электронновычислительных машин используются в том числе в качестве инструмента для заключения и (или) исполнения антиконкурентных соглашений, в частности соглашений, связанных с картелями на торгах и на товарных рынках.

Использование указанных программ позволяет увеличить размер доходов участников антиконкурентного соглашения и, как следствие, ведет к увеличению размера ущерба, причиняемого другим участникам оборота.

Указанные обстоятельства с учетом сложности выявления антиконкурентных соглашений, которые реализуются с использованием программ для электронно-вычислительных машин, повышают общественную опасность антимонопольных правонарушений. В связи с этим существует необходимость создания эффективных механизмов противодействия правонарушениям, совершаемым с использованием программ для электронно-вычислительных машин.

На решение указанной проблемы направлен разработанный ФАС России проект федерального закона «О внесении изменений в Кодекс Российской Федерации об административных правонарушениях», которым предлагается ввести в качестве обстоятельства, отягчающего административную ответственность за заключение и реализацию ограничивающего конкуренцию соглашения, использование для его заключения и (или) исполнения программ для электронно-вычислительных машин.

Аналогичная норма предусматривается проектом федерального закона «Кодекс Российской Федерации об административных правонарушениях» (далее - проект нового КоАП РФ).

4.2. Неполнота правового регулирования административной ответственности хозяйствующих субъектов, организовавших систему внутреннего обеспечения соответствия требованиям антимонопольного законодательства (антимонопольный комплаенс)

Одним из инструментов предупреждения нарушений антимонопольного законодательства и снижения рисков таких нарушений для хозяйствующих субъектов являются разработка и внедрение ими системы внутреннего обеспечения соответствия требованиям антимонопольного законодательства (далее также - антимонопольный комплаенс).

Федеральным законом от 1 марта 2020 г. № 33-Ф3 «О внесении изменений в Федеральный закон «О защите конкуренции» Федеральный закон № 135-Ф3 был дополнен статьей $9^{1}$, предусматривающей право хозяйствующего субъекта организовать систему внутреннего обеспечения соответствия требованиям антимонопольного законодательства путем принятия и применения внутреннего акта (внутренних актов).

Внедрение системы антимонопольного комплаенса направлено на обеспечение эффективного внутреннего контроля за соответствием деятельности организации требованиям антимонопольного законодательства, а также на своевременное выявление и пресечение нарушений таких требований.

В целях стимулирования хозяйствующих субъектов к созданию системы внутреннего обеспечения соответствия требованиям антимонопольного законодательства проектом нового КоАП РФ предлагается установить в качестве обстоятельства, смягчающего административную ответственность, организацию индивидуальным предпринимателем или юридическим лицом, совершившими административное правонарушение, посягающее на конкуренцию, системы антимонопольного комплаенса до момента совершения такого административного правонарушения (при длящемся нарушении - до дня принятия комиссией антимонопольного органа решения, которым установлен факт нарушения антимоно- 
польного законодательства) при соблюдении на момент возбуждения дела об административном правонарушении в совокупности следующих условий:

- в связи с реализацией мер антимонопольного комплаенса административное правонарушение, являющееся длящимся, обнаружено и прекращено, а административное правонарушение, не являющееся длящимся, обнаружено, и хозяйствующим субъектом устранены последствия нарушения антимонопольного законодательства (при наличии таких последствий);

- внесены изменения во внутренний акт (внутренние акты) об организации системы антимонопольного комплаенса в целях предупреждения аналогичных нарушений в дальнейшем.

\section{5. Таможенное регулирование}

В соответствии с пунктом «Ж» статьи 71 Конституции Российской Федерации таможенное регулирование находится в ведении Российской Федерации.

Таможенное регулирование в Российской Федерации осуществляется в соответствии с регулирующими таможенные правоотношения международными договорами Российской Федерации, в том числе с Договором о Таможенном кодексе Евразийского экономического союза, и актами, составляющими право Евразийского экономического союза, а также с Федеральным законом от 3 августа 2018 г. № 289-Ф3 «О таможенном регулировании в Российской Федерации и о внесении изменений в отдельные законодательные акты Российской Федерации», иными федеральными законами, подзаконными нормативными правовыми актами.

В целях обеспечения единства практики применения судами таможенного законодательства в условиях функционирования Евразийского экономического союза 26 ноября 2019 г. Пленум Верховного Суда Российской Федерации принял постановление № 49 «О некоторых вопросах, возникающих в судебной практике в связи с вступлением в силу Таможенного кодекса Евразийского экономического союза».

В указанном постановлении даны разъяснения по вопросам таможенной стоимости ввозимых товаров, классификации товаров для таможенных целей, возврата таможенных платежей, особенностей рассмотрения дел с участием граждан, а также по иным вопросам таможенного контроля и взыскания таможенных платежей.

В ходе мониторинга правоприменения выявлена проблема, требующая решения.

Отсутствие единообразной практики освобождения от налогообложения или применения пониженной налоговой ставки в отношении принадлежностей к медицинским изделиям, ввозимьх на территорию Россий-

ской Федераиии отдельно от медииинских изделий

Согласно абзацам первому и четвертому подпункта 1 пункта 2 статьи 149 Налогового кодекса Российской Федерации (далее - НК РФ) не подлежит обложению (освобождается от обложения) налогом на добавленную стоимость реализация на территории Российской Федерации медицинских товаров, в том числе медицинских изделий, в соответствии с перечнем, утверждаемым Правительством Российской Федерации.

Реализация на территории Российской Федерации указанных медицинских изделий не подлежит налогообложению при условии представления в налоговый орган регистрационного удостоверения медицинского изделия, выданного в соответствии с правом Евразийского экономического союза, или до 31 декабря 2021 г. регистрационного удостоверения на медицинское изделие (регистрационного удостоверения на изделие медицинского назначения (медицинскую технику), выданного в соответствии с законодательством Российской Федерации.

В соответствии с абзацем вторым подпункта 2 статьи 150 НК РФ ввоз указанных медицинских изделий на территорию Российской Федерации и иные территории, находящиеся под ее юрисдикцией, также не подлежит обложению (освобождается от обложения) налогом на добавленную стоимость.

Перечень соответствующих медицинских изделий утвержден постановлением Правительства Российской Федерации от 30 сентября 2015 г. № 1042 «Об утверждении перечня медицинских товаров, реализация которых на территории Российской Федерации и ввоз которых на территорию Российской Федерации и иные территории, находящиеся под ее юрисдикцией, не подлежат обложению (освобождаются от обложения) налогом на добавленную стоимость» (далее - Перечень).

На практике возникает вопрос об освобождении от налогообложения необходимых для применения медицинского изделия по назначению принадлежностей, которые ввозятся на территорию Российской Федерации отдельно.

Поскольку законодательство Российской Федерации не содержит прямого указания на то, что освобождению от налогообложения подлежит ввоз на территорию Российской Федерации принадлежностей к медицинским изделиям отдельно от этих изделий, Федеральная таможенная служба предоставляет указанную льготу только при наличии отдельных регистрационных удостоверений на указанные принадлежности.

Решения об отказе в предоставлении льгот по уплате налога на добавленную стоимость принимаются таможенными органами на основании письменных разъяснений Минфина России, согласно которым освобождение от налога на добавленную стоимость в отношении принадлежностей к медицинским изделиям, ввозимых на территорию Российской Федерации отдельно от этих изделий, применяется при наличии регистрационного удостоверения на такие принадлежности и их включении в Перечень (письма Минфина России от 29 марта 2019 г. № 03-07-11/22009, от 30 марта 2021 г. № 03-07-07/23405).

Вместе с тем в 2018-2020 годах судами отменено порядка 60 решений таможенных органов о взыскании налогов за ввоз в Российскую Федерацию принадлежностей к медицинским изделиям на сумму, превышающую 100 миллионов рублей. Решения судов мотивированы положениями Правил государственной регистрации медицинских изделий, утвержденных постановлением Правительства Российской Федерации от 27 декабря 2012 г. № 1416, а также разъяснениями Росздравнадзора 
(письмо от 28 декабря 2016 г. № 01-63680/16), в соответствии с которыми действие регистрационного удостоверения распространяется как на медицинское изделие, так и на его составляющие и принадлежности к нему.

Таким образом, неоднозначное толкование правовых норм создает дополнительные административные барьеры при отдельном ввозе в Российскую Федерацию принадлежностей к медицинским изделиям, используемым в том числе для борьбы с распространением новой коронавирусной инфекции.

Кроме того, аналогичная ситуация складывается при применении пониженной ставки налога на добавленную стоимость в размере 10 процентов при ввозе на территорию Российской Федерации принадлежностей к медицинским изделиям, не включенным в Перечень (абзац третий подпункта 4 пункта 2 статьи 164 НК РФ).

Для решения указанных вопросов Минздраву России, Минфину России, ФТС России, ФНС России и Росздравнадзору поручено проработать вопрос о необходимости внесения изменений в законодательство Российской Федерации в части освобождения от уплаты налога на добавленную стоимость или применения налоговой ставки в размере 10 процентов в отношении принадлежностей, ввозимых в Российскую Федерацию отдельно от медицинских изделий, и определения порядка подтверждения предназначения таких принадлежностей для соответствующих медицинских изделий.

Приложения 1-4 опубликованы в электронной версии журнала и находятся в свободном доступе на сайте журнала «Мониторинг правоприменения», http://uzulo.su/mon-prav.

Official publications

\section{REPORT ON THE RESULTS OF LAW ENFORCEMENT MONITORING in the RUssian Federation fOR 2020}

Keywords: the Constitutional Court of the Russian Federation, the European Court of Human Rights, major overhaul of buildings, common property, cultural heritage, forests, child neglect, minors, socially endangered status, anti-competitive agreements, customs regulation, taxation, medical devices.

Abstract. This publication is to ensure the public policy based on the principle of openness and accessibility of legal information. The report presents a generalisation of information on the state of legislation and its practical use in various spheres of life and areas of activity, which allows to understand the tendencies of development and to take into account the opinions of all participants in social relations. Law enforcement monitoring is an important activity for today's Russia which allows to ensure improving the legislation.

Appendices 1-4 to the Report are published in the electronic version of the journal and are freely accessible on the site of the Monitoring of Law Enforcement journal http://uzulo.su/mon-prav 


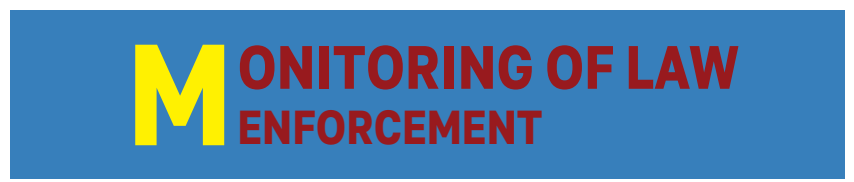

PEER-REVIEWED SCHOLARLY JOURNAL 2021, No. 4(41)

The journal is published quarterly.

Registered by the Federal Service for Supervision in the Sphere of Telecom, Information Technologies and Mass Communications. Registration Certificate No. FS77-49472 of the 24th of April 2012.

The journal is on the list of scholarly publications approved by the Higher Attestation Commission under the Ministry of Science and Higher Education of Russia

\begin{tabular}{l}
\hline \multicolumn{1}{c}{ Editor-in-Chief } \\
Aleksandr KARTSKHIIA, \\
Dr.Sc. (Law), Assoc. Prof., Moscow \\
Executive Editor, \\
Grigory MAKARENKo, Moscow
\end{tabular}

\section{Editorial Board}

Elena ANTONYAN, Dr.Sc. (Law), Prof., Moscow

Andrei GABOV, Dr.Sc. (Law), Prof., corr. member of the Rus. Acad. of Sciences, Moscow

Elizaveta DEMIDOVA-PETROVA, Dr.Sc. (Law), Assoc. Prof., Kazan

Vladimir ZAITSEV, Dr.Sc. (Law), Prof., Moscow

Sergei ZAPOL'SKII, Dr.Sc. (Law), Prof., Moscow

Sergei ZAKHARTSEV, Dr.Sc. (Law), Prof., Moscow

Oleg ZIBOROV, Dr.Sc. (Law), Assoc. Prof., Moscow

Pavel KABANOV, Dr.Sc. (Law), Assoc. Prof., Kazan

Igor' MATSKEVICH, Dr.Sc. (Law), Prof., Moscow

El'mira ATAGIMOVA, Ph.D. (Law), Moscow

Vladimir RADCHENKO, Ph.D. (Law), Assoc. Prof., Moscow

Valentin BABINTSEV, Dr.Sc. (Sociology), Prof., Belgorod

Valerii MARKIN, Dr.Sc. (Sociology), Prof., Moscow

Mikhail MALYSHEV, Dr.Sc. (Sociology), Prof., Moscow

Anatolii SILIN, Dr.Sc. (Sociology), Prof., Tyumen

Ol'ga URZHA, Dr.Sc. (Sociology), Prof., Moscow

\section{Foreign Members}

Viktor SHARSHUN, Ph.D. (Law), Minsk, the Republic of Belarus

\section{Founder and publisher:}

Federal State-Funded Institution "Scientific Centre for Legal Information under the Ministry of Justice of the Russian

Federation" (SCLI)

Postal address:

Mikhalkovskaya str., bld. 65/1, 125438, Moscow, Russia Telephone: +7 (985) 939-75-01

E-mail:monitorlaw@yandex.com

Guidelines for preparing manuscripts for publication and archive files are available on the website http:/uzulo.su/mon-prav

Printed by the Printing and Publication Division of the SCLI. Approved for print on the 27th of December 2021.

Number of items printed: 120 . Free price.

\section{CONTENTS}

PHILOSOPHY OF LAW

ON THE QUESTION OF PROSPECTS FOR A MODERN INTERPRETATION OF NATURAL LAW: THE LEGAL PHILOSOPHICAL AND THEOLOGICAL ASPECTS

S. Zakhartsev, D. Maslennikov, V. Sal'nikov . ................. 2

CONSTITUTIONAL LAW

PROPORTIONALITY AS AN INDEPENDENT CONSTITUTIONAL PRINCIPLE OF THE RUSSIAN FEDERATION

S. Khorunzhii ..............................

\section{CIVIL LAW SCIENCE}

IMPLEMENTATION OF THE "REGULATORY GUILLOTINE"

AT THE REGIONAL AND MUNICIPAL LEVEL

I. Andreechev. . . . . . . . . . . . . . . . . . . . . . 21

SATISFACTION OF OBLIGATIONS TO THE SOLE CREDITOR BY A THIRD PARTY AFTER INTRODUCING THE INSOLVENCY SUPERVISION REGIME

V. Zaitsev, A. Kravchenko, V. Bedrosov. . . . . . . . . . . . . . 31

PROSPECTS FOR AND LEGAL PROBLEMS OF MICROGENERATION DEVELOPMENT IN RUSSIA

S. Kodaneva.................................. 40

CLIMATE LAW

LAWS ON CLIMATE UNDER THE CONDITIONS OF ENERGY TRANSITION TO LOW-CARBON ECONOMY

A. Kartskhiia................................ 49

LEGAL AWARENESS RAISING

ORGANISATION OF LEGAL AWARENESS RAISING IN THE SUBJECTS OF THE RUSSIAN FEDERATION

P. Kabanov. .................................. 56

CRIMINAL LAW SCIENCE

CERTAIN FEATURES CHARACTERISING CORRUPTION CRIME IN URBAN AREAS (USING DATA FROM THE REPUBLIC OF TATARSTAN)

D. Akhunov. . . . . . . . . . . . . . . . . . . . . . . . . . . 68

SIGNIFICANCE OF EVIDENCE IN THE THEORY OF CRIMINAL PROCEDURE PROOF: PROBLEMS AND WAYS TO SOLVE THEM

T. Garipov . . . . . . . . . . . . . . . . . . . . . . . . . . . . . . 74

DISCUSSION FORUM

PROPOSALS FOR IMPROVING THE SYSTEM OF APPLYING DIGITAL TECHNOLOGIES IN LAW-MAKING AND LAW ENFORCEMENT PROCESSES N. Troian . . . . . . . . . . . . . . . . . . . . . . . . . . . . 82

REVIEWS

REVIEW OF THE MONOGRAPH BY SERGEI ZAKHARTSEV

"LAW: NEW IDEAS AND READINGS"

V. Sal'nikov, A. Khabibulin, A. Chislov .................. 93

OFFICIAL PUBLICATIONS

REPORT ON THE RESULTS OF LAW ENFORCEMENT MONITORING

IN THE RUSSIAN FEDERATION FOR $2020 \ldots \ldots \ldots \ldots \ldots \ldots$. . . 99

The journal can be subscribed to at post offices through the Press of Russia (Pressa Rossii) Catalogue. Publication index: 44723 